The Alaska Volcano Observatory is a cooperative program of the U.S. Geological Survey, University of Alaska Fairbanks Geophysical Institute, and the Alaska Division of Geological and Geophysical Surveys. The Alaska Volcano Observatory is funded by the U.S. Geological Survey Volcano Hazards Program and the State of Alaska.

\title{
2007 Volcanic Activity in Alaska, Kamchatka, and the Kurile Islands: Summary of Events and Response of the Alaska Volcano Observatory
}

\section{Scientific Investigations Report $2010=5242$}

U.S. Department of the Interior U.S. Geological Survey 
Cover: Pavlof Volcano and eruption plume on the evening of August 30, 2007, 21:21

AKDT. View is to the south. Plume height approximately $17-18,000$ feet $(5-5.5 \mathrm{~km})$.

Photograph by Chris Waythomas, AVO/USGS. AVO database image at URL: http://www. avo.alaska.edu/images/image.php?id=13551. 


\section{Volcanic Activity in Alaska, Kamchatka, and the Kurile Islands: Summary of Events and Response of the Alaska Volcano Observatory}

By Robert G. McGimsey, Christina A. Neal, James P. Dixon, U.S. Geological Survey; Nataliya Malik, Institute of Volcanology and Seismology; and Marina Chibisova, Institute of Marine Geology and Geohysics

The Alaska Volcano Observatory is a cooperative program of the U.S. Geological Survey, University of Alaska Geophysical Institute, and the Alaska Division of Geological and Geophysical Surveys. The Alaska Volcano Observatory is funded by the U.S. Geological Survey Volcano Hazards Program and the State of Alaska.

Scientific Investigations Report 2010-5242 


\section{U.S. Department of the Interior \\ KEN SALAZAR, Secretary \\ U.S. Geological Survey \\ Marcia K. McNutt, Director}

\section{U.S. Geological Survey, Reston, Virginia: 2011}

For more information on the USGS - the Federal source for science about the Earth, its natural and living resources, natural hazards, and the environment, visit http://www.usgs.gov or call 1-888-ASK-USGS

For an overview of USGS information products, including maps, imagery, and publications, visit http://www.usgs.gov/pubprod

To order this and other USGS information products, visit http://store.usgs.gov

Any use of trade, product, or firm names is for descriptive purposes only and does not imply endorsement by the U.S. Government.

Although this report is in the public domain, permission must be secured from the individual copyright owners to reproduce any copyrighted materials contained within this report.

Suggested citation:

McGimsey, R.G., Neal, C.A., Dixon, J.P., Malik, Nataliya, and Chibisova, Marina, 2011, 2007 Volcanic activity in Alaska, Kamchatka, and the Kurile Islands: Summary of events and response of the Alaska Volcano Observatory: U.S. Geological Survey Scientific Investigations Report 2010-5242, 110 p. 


\section{Contents}

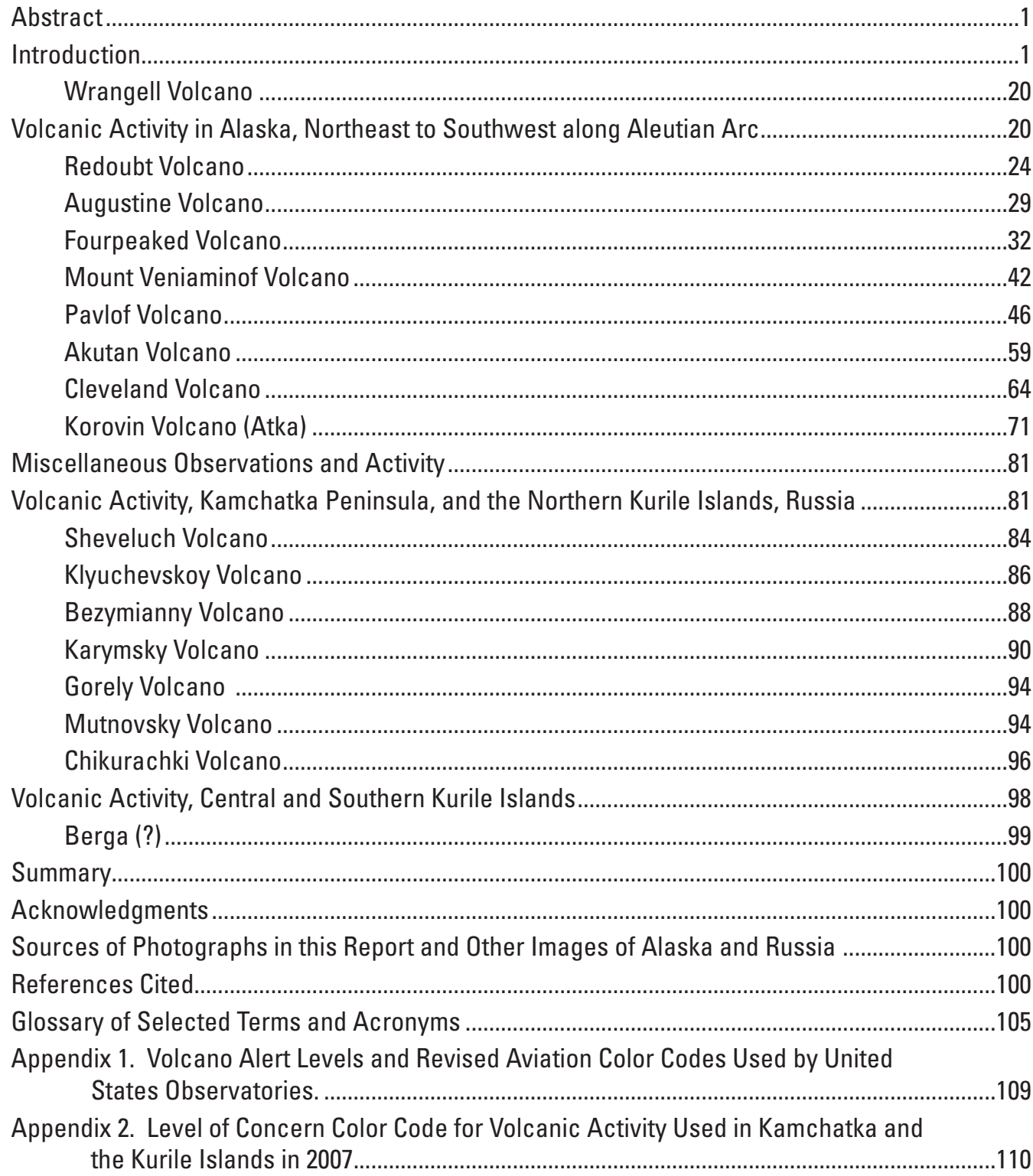




\section{Figures}

Figure 1. Map showing historically active volcanoes in Alaska along with place names used in this report

Figure 2. Alaska Volcano Observatory Information Release, Thursday, November 8 , 2007, announcing the implementation of new volcano hazard notifications for volcanic activity.

Figure 3. Samples of the new Volcanic Activity Notice (VAN) and Volcanic Activity Notice for Aviation (VONA)

Figure 4. Photograph showing all known active fumaroles on Wrangell were venting steam on this cold (minus $20^{\circ} \mathrm{F}$; minus $29^{\circ} \mathrm{C}$ ) morning at 9 a.m. AKDT on March 20, 2007

Figure 5. Photograph showing steam rising from fumaroles in the summit craters of Wrangell as from the prominent fumarole field high on the southwest flank (about 12,000 ft ASL) at 3 p.m. AKDT on March 20, 2007, from approximately Mile 18 of the Tok Highway

Figure 6. Photograph showing northwest flank of Wrangell volcano with a dark stripe of probable redistributed ash extending from one of the summit cinder cones (West Crater?)

Figure 7. Photographs showing views from the north of the summit crater of Redoubt Volcano from 1990 to 2007

Figure 8. Photograph showing Redoubt Volcano, view of the north flank and summit crater on September 10, 2002

Figure 9. Photographs showing probable steam plume emanating from Redoubt Volcano on February 25, 2007

Figure 10. Photograph showing summit crater of Redoubt Volcano on May 18, $2007 \quad \ldots \ldots \ldots 28$

Figure 11. Photograph showing steam plume and warm ground on the summit of Augustine, February 22, 2007.

Figure 12. Photographs showing steam plumes rising from Augustine .................... 31

Figure 13. Photograph showing view from the northwest of the line of vents issuing steam and volcanic gases at Fourpeaked volcano, November 4, 2006

Figure 14. Photograph showing steam and gas plume drifting southward from Fourpeaked volcano, February 2, 2007 34

Figure 15. Successive AVHRR satellite images showing development of a steam plume

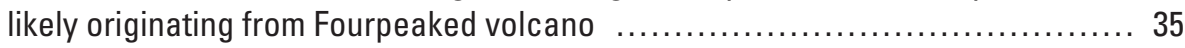

Figure 16. Web camera images from January 14 and February 10, $2007 \ldots \ldots \ldots \ldots \ldots \ldots \ldots . \ldots . \ldots 36$

Figure 17. Photograph showing vigorous emission of steam and gas from vents located near the summit of Fourpeaked volcano, February 22, 2007

Figure 18. Photograph showing uppermost and largest of the active vents on Fourpeaked volcano during an AVO aerial gas-measurement flight, February 22, 2007 38

Figure 19. Histogram plot of earthquakes recorded at Fourpeaked volcano between August 31, 2006, and December 21, 2007, showing a decrease in the number of events from February through April, 2007

Figure 20. Photograph showing steam and possibly some gas continues to rise from vents near the summit of Fourpeaked volcano, May 18, 2007

Figure 21. Web camera image of Fourpeaked volcano on June 11, 2007, showing continued emission of a small steam plume

Figure 22. Web camera images of vigorous emission of steam from the intracaldera cone in the Veniaminof caldera 


\section{Figures-Continue}

Figure 23. Digital elevation model of Veniaminof volcano showing the dimensions of this massive volcano, and the location of seismic stations .....

Figure 24. Web camera image showing a steam plume wafting up from the intracaldera cinder cone in Veniaminof caldera, August 7, 2007

Figure 25. Photograph showing steam and ash erupting from Pavlof Volcano, August 29, 2007

Figure 26. Photograph showing upper southeast flank of Pavlof Volcano and incandescent lava fountaining from the active vent-here about $50-70 \mathrm{~m}$ (160-230 ft) in diameter-during the 2007 eruption

Figure 27. NOAA AVHRR satellite image showing a strong thermal anomaly observed at the summit of Pavlof Volcano, August 16, 2007 at 0750 AKDT (1550 UTC)

Figure 28. Photograph showing steam and incandescent lava at Pavlof Volcano on the evening of August 28, 2007

Figure 29. FLIR image of the lava flow at Pavlof Volcano on August 18, 2007, viewed from the southeast placed in approximately the correct position over a photograph of the summit at about the same time

Figure 30. FLIR image of the upper southeast flank of Pavlof Volcano showing the vent area about $200 \mathrm{~m}(660 \mathrm{ft})$ below the summit of the volcano, August 18, 2007

Figure 31. Oblique 3D perspective view of Pavlof on September 10, 2007, from the southeast of the hottest ASTER shortwave infrared (SWIR-30 m) pixels draped onto a June 23, 2007, daytime ASTER view

Figure 32. Photograph showing south side of the summit of Pavlof Volcano and various features and deposits, September 19, 2007

Figure 33. Photograph showing south flank of Pavlof Volcano and the 1986 and 2007 vents, spatter-fed lava flow chute, area of warm ground, and dust/ash plume produced by small rockfall from the recently emplaced lava flow

Figure 34. Graph showing Real-time Seismic-Amplitude Measurement (RSAM) in 1-hour increments, from Pavlof seismic station PV6 EHZ AV, August 13, 2007-

September 13, 2007

Figure 35. Photograph showing lahar deposits produced by the August-September 2007 eruption of Pavlof Volcano

Figure 36. Seismicity at Akutan volcano triggered by the January 13, 2007, M8.2 Kurile Islands earthquake 60

Figure 37. Photograph showing steam column rising from upper Hot Springs Bay, a prominent valley draining the east flank of Akutan volcano

Figure 38. Shaded relief map of Akutan Island showing the caldera, Hot Springs Bay thermal springs, east flank fumarole field, Trident Sea Food plant, and the approximate area of rising steam observed by the plant manager on October 8, 2007

Figure 39. Oblique aerial photograph of Akutan volcano, June 28, 2000

Figure 40. Satellite image of a thermal anomaly and an associated steam plume at Cleveland volcano on the morning of July 20, 2007, suggesting that low-level eruptive activity was occurring

Figure 41. Oblique 3-D view of Cleveland volcano on July 20, 2007, using Advanced Spaceborne Thermal Emission and Reflection (ASTER) radiometer visible and near-infrared data draped over Shuttle Radar Topography Mission (SRTM) topography 


\section{Figures-Continued}

Figure 42. Photographs showing development of a small, diffuse ash plume at Cleveland volcano on July 20,2007, rising about $900 \mathrm{~m}(3,000 \mathrm{ft})$ above the summit and drifting to the south, characteristic of the eruptive activity during the summer of 2007

Figure 43. Photograph showing oblique aerial view of the $2,730 \mathrm{~m}(5,676 \mathrm{ft})$ summit of Cleveland volcano on July 27, 2007

Figure 44. Photograph showing Cleveland ASTER data acquired September 13, 2007, at

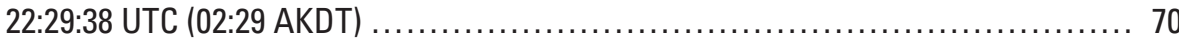

Figure 45. Graph showing number of monthly earthquakes for Korovin Volcano, 2006-07 _. 72

Figure 46. Seismicity at Korovin and Kliuchef Volcanoes on Atka Island from January 26, 2007, to August 21, 2007, and cumulative seismicity from April 2005 to August 21, 2007 .

Figure 47. Photograph showing large steam plume rising from Korovin Volcano on January 23, 2007

Figure 48. Photographs showing ash on the west flank of Korovin Volcano, March 3, 2007

Figure 49. Photograph showing steam column rising from Korovin Volcano on July 27, 2007 as seen from Atka Village .... 76

Figure 50. Photograph showing Korovin Volcano as seen from 30,000 feet (9.1 km) ASL on August 5, 2007

Figure 51. A several-pixel mass of $\mathrm{SO}_{2}$ immediately northeast of Korovin Volcano on Atka Island as measured by Ozone Monitoring Instrument (OMI) on August 20, 2007

Figure 52. InSAR interferogram for the northern part of Atka Island acquired on July 1, 2007, showing the circular pattern of uplift centered on the west flank of Kliuchef.

Figure 53. InSAR interferograms that span from 35 days to about 1 year from October 2006 to August 2007

Figure 54. Map of Kamchatka Peninsula and the northern Kurile Islands of Alaid and Paramushir 81

Figure 55. Photograph showing view of Sheveluch Volcano from the International Space Station, July 10, 2007 85

Figure 56. Photograph showing Klyuchevskoy Volcano in eruption, June 2007 .............. 87

Figure 57. Photograph showing Bezymianny pyroclastic flow deposit from the November 5 eruption

Figure 58. ASTER satellite image of Karymsky Volcano, March 25, 2007 ................. 91

Figure 59. Photograph showing ash explosion from Karymsky Volcano, April 21, 2007 ....... 92

Figure 60. Photograph showing ash explosion from Karymsky Volcano, July 12, 2007 ........ 93

Figure 61. Photograph showing explosive vent in the active crater of Mutnovsky Volcano

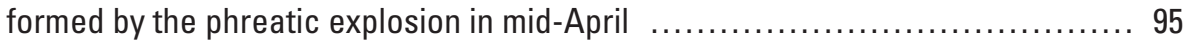

Figure 62. MODIS image of Chikurachki plume on September 19, $2007 \ldots \ldots \ldots \ldots \ldots \ldots \ldots \ldots . \ldots 7$

Figure 63. Photograph showing Chikurachki ash plume, extending to the southeast from the volcano

Figure 64. Map of Kurile Islands showing Berga and Chikurachki Volcanoes .............. 98

Figure 65. Photograph showing sulfur dioxide cloud detected in the Kurile Islands on April 14, 2007, by the OMI sensor 


\section{Tables}

Table 1. History of seismic monitoring of Alaskan volcanoes from August 1971 through

December 2007 3

Table 2. Summary of 2007 VOLCANIC ACTIVITY in Alaska, including actual eruptions, possible eruptions, unusual increases in seismicity or fumarolic activity $\quad \ldots \ldots \ldots 10$

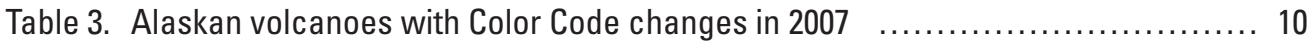

Table 4a. Compilation by year of volcanoes included in an Alaska Volcano Observatory Annual Summary, 1992-2007 ......................................... 11

Table 4b. Compilation by volcano for particular years included in an Alaska Volcano Observatory Annual Summary, 1992-2007 ............................. 13

Table 4c. Citations for Alaska Volcano Observatory Annual Summary reports, 1992-2006 ... 18

Table 5. 2007 activity at Cleveland volcano, compiled from Alaska Volcano Observatory information-release statements, internal-log entries, and summaries. ............6 65

Table 6. Seismically monitored volcanoes of Kamchatka and Atlasova Island as of December 2007. 82

Table 7. Summary of VOLCANIC ACTIVITY on Kamchatka Peninsula and in the Kurile Islands, Russia, 2007. 83

Table 8. Level of Concern Color Code changes for Kamchatkan volcanoes in $2007 \quad$........ 83

\section{Conversion Factors and Datum}

Conversion Factors

Inch-Pound to SI

\begin{tabular}{lcl}
\hline \multicolumn{1}{c}{ Multiply } & \multicolumn{1}{c}{ By } & \multicolumn{1}{c}{ To obtain } \\
\hline acre & 4,047 & square meter $\left(\mathrm{m}^{2}\right)$ \\
cubic mile $\left(\mathrm{mi}^{3}\right)$ & 4.168 & cubic kilometer $\left(\mathrm{km}^{3}\right)$ \\
foot (ft) & 0.000305 & kilometer $(\mathrm{km})$ \\
foot (ft) & 0.3048 & meter $(\mathrm{m})$ \\
inch (in.) & 2.54 & centimeter $(\mathrm{cm})$ \\
inch (in.) & 25.4 & millimeter $(\mathrm{mm})$ \\
mile (mi) & 1.609 & kilometer $(\mathrm{km})$ \\
ton per day (ton/d) & 0.9072 & metric ton per day \\
\hline
\end{tabular}

Temperature in degrees Fahrenheit $\left({ }^{\circ} \mathrm{F}\right)$ may be converted to degrees Celsius $\left({ }^{\circ} \mathrm{C}\right)$ as follows:

${ }^{\circ} \mathrm{C}=\left({ }^{\circ} \mathrm{F}-32\right) / 1.8$ 


\section{Conversion Factors and Datum-Continued}

Conversion Factors

SI to Inch-Pound

\begin{tabular}{lll}
\hline Multiply & By & To obtain \\
\hline cubic kilometer $\left(\mathrm{km}^{3}\right)$ & 0.2399 & cubic mile $\left(\mathrm{mi}^{3}\right)$ \\
kilometer $(\mathrm{km})$ & 0.6214 & mile $(\mathrm{mi})$ \\
kilometer $(\mathrm{km})$ & 3,281 & foot $(\mathrm{ft})$ \\
meter $(\mathrm{m})$ & 3.281 & foot $(\mathrm{ft})$ \\
centimeter $(\mathrm{cm})$ & 0.3937 & inches (in.) \\
metric ton per day & 1.1022 & ton per day (ton/d) \\
millimeter $(\mathrm{mm})$ & 0.03937 & inch (in.) \\
square meter $\left(\mathrm{m}^{2}\right)$ & 0.0002471 & acre \\
\hline
\end{tabular}

Temperature in degrees Celsius $\left({ }^{\circ} \mathrm{C}\right)$ may be converted to degrees Fahrenheit $\left({ }^{\circ} \mathrm{F}\right)$ as follows:

$$
{ }^{\circ} \mathrm{F}=\left(1.8 x^{\circ} \mathrm{C}\right)+32 \text {. }
$$

Datum

Altitude and elevation as used in this report, refers to distance above sea level, unless otherwise noted. 


\title{
2007 Volcanic Activity in Alaska, Kamchatka, and the Kurile Islands: Summary of Events and Response of the Alaska Volcano Observatory
}

\author{
By Robert G. McGimsey', Christina A. Neal1', James P. Dixon², Nataliya Malik², and Marina Chibisova ${ }^{4}$
}

\section{Abstract}

The Alaska Volcano Observatory (AVO) responded to eruptions, possible eruptions, and volcanic unrest at or near nine separate volcanic centers in Alaska during 2007. The year was highlighted by the eruption of Pavlof, one of Alaska's most frequently active volcanoes. Glaciated Fourpeaked Mountain, a volcano thought to have been inactive in the Holocene, produced a phreatic eruption in the autumn of 2006 and continued to emit copious amounts of steam and volcanic gas into 2007. Redoubt Volcano showed the first signs of the unrest that would unfold in 2008-09. AVO staff also participated in hazard communication and monitoring of multiple eruptions at seven volcanoes in Russia as part of its collaborative role in the Kamchatka and Sakhalin Volcanic Eruption Response Teams.

\section{Introduction}

The Alaska Volcano Observatory (AVO) monitors, reports, and studies volcanic unrest at Alaskan volcanoes. The year 2007 was dominated by the eruption of Pavlof Volcano. AVO also responded to new and ongoing volcanic unrest at several other volcanoes in Alaska, including Wrangell, Redoubt, Augustine, Fourpeaked, Veniaminof, Akutan, Cleveland, and Korovin (fig. 1). A section on miscellaneous observations and activity is added to capture some retrospectively significant information.

\footnotetext{
${ }^{1}$ U.S. Geological Survey, Alaska Volcano Observatory, Volcano Science Center, 4200 University Drive, Anchorage, Alaska 99508-4664.

${ }^{2}$ U.S. Geological Survey Alaska Volcano Observatory, 903 Koyukuk Drive, Fairbanks, Alaska 99775-7320.

${ }^{3}$ Kamchatka Volcanic Eruptions Response Team, Institute of Volcanology and Seismology, Piip Boulevard, 9 Petropavlovsk-Kamchatsky, Russia 683006.

${ }^{4}$ Sakhalin Volcanic Eruptions Response Team, Institute of Marine Geology and Geophysics, Nauki Street,Yuzhno-Sakhalinsk, Russia 693022.
}

Of the more than 50 historically active volcanoes in Alaska, 31 were monitored in 2007 with a network of seismometers sufficiently reliable in their operation to consistently track earthquake activity (fig. 1; table 1). Seismic stations also were in place at two additional volcanoes [Little Sitkin and Semisopochnoi (fig. 1)]; however, telemetry links are intermittent and background seismicity has not been confidently determined. Thus, AVO does not yet consider these volcanoes formally monitored with seismic instrumentation. AVO's routine monitoring program includes twice-daily analysis of seismicity and satellite imagery, Web cameras, occasional overflight observations and airbornegas measurements, and compilation of pilot reports and observations of local residents and mariners. Additionally, AVO receives real-time deformation information from permanent Global Positioning System (GPS) stations at four Alaskan volcanoes (Okmok, Augustine, Akutan, and Mount Spurr). In recent years, periodic analysis of Interferometric Synthetic Aperture Radar (InSAR) imagery also has been used to detect deformation at volcanoes in Alaska (Lu and others, 2003; Lu, 2007; Lu and others, 2007).

AVO continues to participate by formal agreement with the Kamchatkan Volcanic Eruption Response Team (KVERT; Kirianov and others, 2002) and the Sakhalin Volcanic Eruption Response Team (SVERT; Rybin and others, 2004) to aid in satellite monitoring of Russian volcanoes and support dissemination of hazard information. In 2007, AVO assisted in broadcasting alerts about eruptive activity at six Russian volcanoes in Kamchatka (Sheveluch, Klyuchevskoy, Bezymianny, Karymsky, Gorely, and Mutnovsky). Explosions at Chikurachki, a volcano on Paramushir Island in the North Kuriles, produced intermittent ash clouds during a 2-month period. No other volcanoes in the Kuriles exhibited significant unrest in 2007, although an ash cloud may have been generated from a small island volcano, Berga; this cloud also may have come from nearby Chikurachki, which was active at the time. SVERT issued no formal warnings in 2007. 


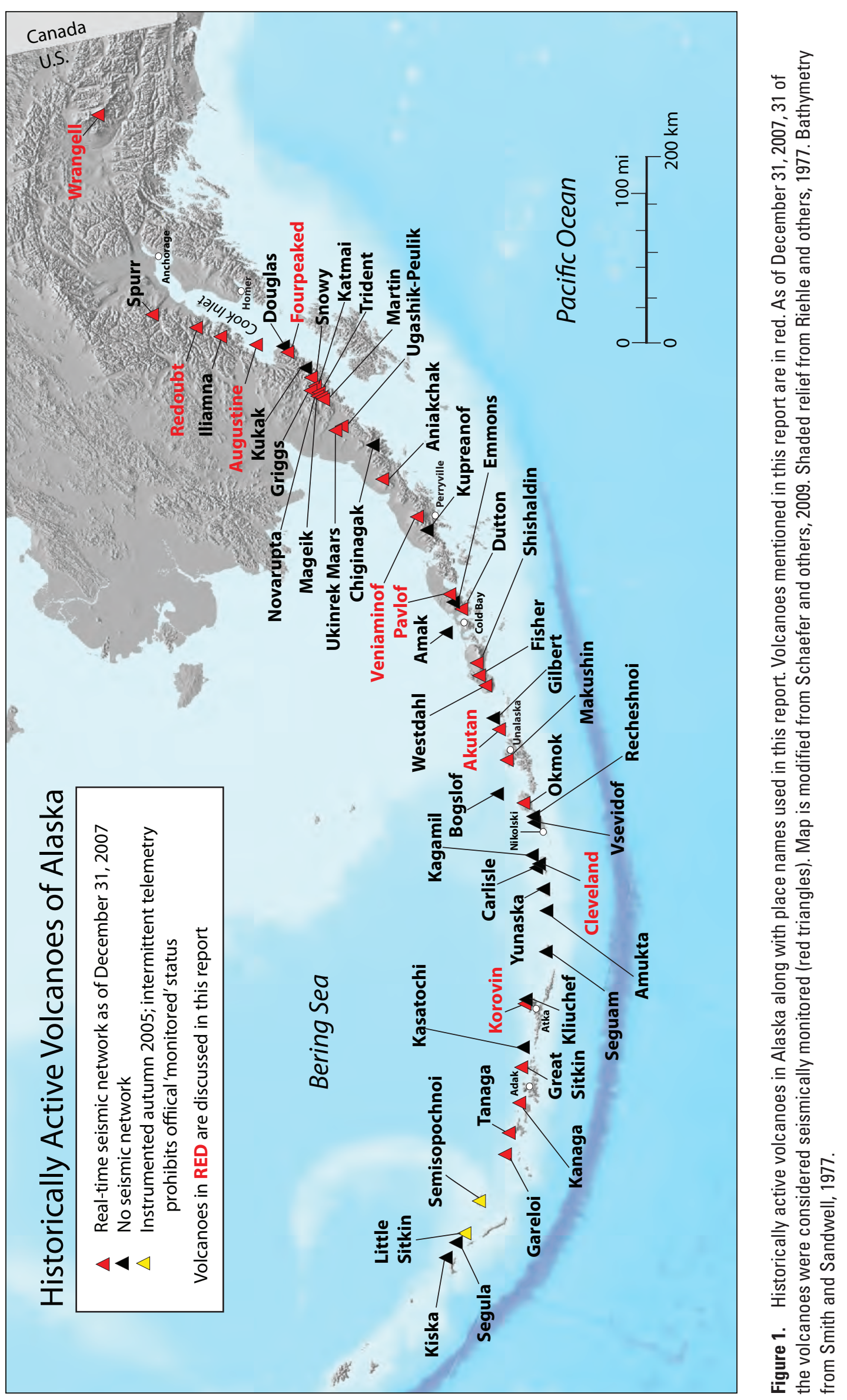


Table 1. History of seismic monitoring of Alaskan volcanoes from August 1971 through December 2007.

[History of seismic monitoring compiled by J. Dixon, U.S. Geological Survey. "First station installed" is defined as the receipt of realtime data from the station. This date can be many months following initial fieldwork at the volcano. Alaska Volcano Observatory (AVO) considers the seismic network "complete" following installation and data transmission from a minimum of four seismic stations. Typically, AVO seismologists wait about 6 months or more to understand background rates of seismicity before formally declaring a volcano seismically monitored and adding it to the monitored list. We note here the first mention of the seismic status of each monitored volcano in the AVO weekly update. Regularly issued written information statements began during the Redoubt eruption in 1989-90 and were expanded to include all Cook Inlet volcanoes in April 1991. The Magnitude of Completeness is the lowest magnitude that can confidently be located for activity detected in 2007]

\begin{tabular}{|c|c|c|}
\hline Volcano & Approximate start date of seismic monitoring & $\begin{array}{l}\text { Magnitude of } \\
\text { completeness }\end{array}$ \\
\hline Wrangell & $\begin{array}{l}\text { First station installed - July } 2000 \\
\text { Network complete - August } \mathbf{2 0 0 1} \\
\text { Added to monitored list in weekly update - November } 2001\end{array}$ & 1.0 \\
\hline Spurr & $\begin{array}{l}\text { First station installed - August } 1971 \\
\text { Network complete - August } 1989 \\
\text { Added to monitored list in weekly update - April } 1991\end{array}$ & 0.2 \\
\hline Redoubt & $\begin{array}{l}\text { First station installed - August } 1971 \\
\text { Network complete - August } \mathbf{1 9 8 8} \\
\text { Added to monitored list in weekly update - April } 1991\end{array}$ & 0.5 \\
\hline Iliamna & $\begin{array}{l}\text { First station installed - September } 1987 \\
\text { Network complete (Min } 4 \text { stations) - September } 1994 \\
\text { Added to monitored list in weekly update - April } 1991\end{array}$ & 0.3 \\
\hline Augustine & $\begin{array}{l}\text { First station installed - October } 1976 \\
\text { Network complete - August } \mathbf{1 9 7 8} \\
\text { Added to monitored list in weekly update - April } 1991\end{array}$ & 0.1 \\
\hline Fourpeaked & $\begin{array}{l}\text { First station installed - August } 1991 \\
\text { Network complete - October } 2006 \\
\text { Added to monitored list in weekly update - May } 2007\end{array}$ & 0.3 \\
\hline Katmai-North (Snowy) & $\begin{array}{l}\text { First station installed - August } 1988 \\
\text { Network complete - October } 1998 \\
\text { Added to monitored list in weekly update - December } 1998\end{array}$ & 0.9 \\
\hline $\begin{array}{l}\text { Katmai-Central (Griggs, Katmai, } \\
\text { Novarupta, Trident) }\end{array}$ & $\begin{array}{l}\text { First station installed - August } 1988 \\
\text { Network complete (Min } 4 \text { stations) - July } 1991 \\
\text { Added to monitored list in weekly update - November } 1996\end{array}$ & 0.4 \\
\hline Katmai-South (Martin, Mageik) & $\begin{array}{l}\text { First station installed - August } 1988 \\
\text { Network complete - July } 1996 \\
\text { Added to monitored list in weekly update - November } 1996\end{array}$ & 0.2 \\
\hline Ukinrek Maars/ Peulik & $\begin{array}{l}\text { First station installed - March } 2005 \\
\text { Network complete (Min } 4 \text { stations) - March } 2005 \\
\text { Added to monitored list in weekly update - April } 2005\end{array}$ & 1.3 \\
\hline Aniakchak & $\begin{array}{l}\text { First station installed - July } 1997 \\
\text { Network complete - July } 1997 \\
\text { Added to monitored list in weekly update - November } 1997\end{array}$ & 1.3 \\
\hline Veniaminof & $\begin{array}{l}\text { First station installed - February } 2002 \\
\text { Network complete - February } 2002 \\
\text { Added to monitored list in weekly update - September } 2002\end{array}$ & 1.4 \\
\hline Pavlof & $\begin{array}{l}\text { First station installed - July } 1996 \\
\text { Network complete - July } 1996 \\
\text { Added to monitored list in weekly update - November } 1996\end{array}$ & 1.5 \\
\hline Dutton & $\begin{array}{l}\text { First station installed - July } 1988 \\
\text { Network complete - July } 1996 \\
\text { Added to monitored list in weekly update - November } 1996\end{array}$ & 1.2 \\
\hline
\end{tabular}


Table 1. History of seismic monitoring of Alaskan volcanoes from August 1971 through December 2008.—Continued

\begin{tabular}{|c|c|c|}
\hline Volcano & Approximate start date of seismic monitoring & $\begin{array}{l}\text { Magnitude of } \\
\text { completeness }\end{array}$ \\
\hline Shishaldin (and Isantoski) & $\begin{array}{l}\text { First station installed - July } 1997 \\
\text { Network complete - July } 1997 \\
\text { Shishaldin added to list in weekly update - November } 1997 \\
\text { Isantoski added to list in weekly update - December } 1998\end{array}$ & 1.7 \\
\hline Westdahl (and Fisher) & $\begin{array}{l}\text { First station installed - August } 1998 \\
\text { Network complete - October } 1998 \\
\text { Added to monitored list in weekly update - December } 1998\end{array}$ & 1.5 \\
\hline Akutan & $\begin{array}{l}\text { First station installed - March } 1996 \\
\text { Network complete - July } 1996 \\
\text { Added to monitored list in weekly update - November } 1996\end{array}$ & 1.0 \\
\hline Makushin & $\begin{array}{l}\text { First station installed - July } 1996 \\
\text { Network complete - July } 1996 \\
\text { Added to monitored list in weekly update - November } 1996\end{array}$ & 0.9 \\
\hline Okmok & $\begin{array}{l}\text { First station installed - January } 2003 \\
\text { Network complete - January } 2003 \\
\text { Added to monitored list in weekly update - January } 2004\end{array}$ & 0.9 \\
\hline Korovin & $\begin{array}{l}\text { First station installed - July } 2004 \\
\text { Network complete - July } 2004 \\
\text { Added to monitored list in weekly update - December } 2005\end{array}$ & 0.7 \\
\hline Great Sitkin & $\begin{array}{l}\text { First station installed - September } 1999 \\
\text { Network complete - September } 1999 \\
\text { Added to monitored list in weekly update - December } 1999\end{array}$ & 0.2 \\
\hline Kanaga & $\begin{array}{l}\text { First station installed - September } 1999 \\
\text { Network complete - September } 1999 \\
\text { Added to monitored list in weekly update - December } 2000\end{array}$ & 1.1 \\
\hline Tanaga & $\begin{array}{l}\text { First station installed - August } 2003 \\
\text { Network complete - August } 2003 \\
\text { Added to monitored list in weekly update - June } 2004\end{array}$ & 1.2 \\
\hline Gareloi & $\begin{array}{l}\text { First station installed - August } 2003 \\
\text { Network complete - September } 2003 \\
\text { Added to monitored list in weekly update - June } 2004\end{array}$ & 1.2 \\
\hline Semisopochnoi (Cerberus) & $\begin{array}{l}\text { First station installed - September } 2005 \\
\text { Network complete - September } 2005 \\
\text { Added to monitored list in weekly update - not yet added }\end{array}$ & 0.5 \\
\hline Little Sitkin & $\begin{array}{l}\text { First station installed - September } 2005 \\
\text { Network complete - September } 2005 \\
\text { Added to monitored list in weekly update - not yet added }\end{array}$ & 0.5 \\
\hline
\end{tabular}




\section{AVO implements new volcano hazard notifications in 2007}

On November 8, 2007, AVO issued an Information Release announcing a new format for written notices of volcanic activity (fig. 2). A Volcanic Activity Notice (VAN) will be used to announce eruptions, other significant activity, and color code and alert level changes for Alaskan volcanoes (fig. 3). For aviation customers, a Volcano Observatory Notification for Aviation (VONA) will be distributed with a highly formatted message focusing on ash cloud hazards. This change is meant to provide a clearer and more consistent statement of volcano hazard information, and the more structured format of the VAN and VONA will hopefully enable users to quickly find the hazard content of most interest. Daily Status reports and Weekly summaries remain largely unchanged; Information Releases have been replaced by Information Statements.

This report summarizes volcanic activity in Alaska, Kamchatka, and the Kuriles in 2007 and briefly describes AVO's operational response. Descriptions are presented in geographic order from northeast to southwest along the Aleutian Arc, and north to south in Kamchatka and the Kuriles. Each event summary ends with a paragraph providing background comments on the volcano in question. Information primarily is derived from AVO daily status reports, weekly updates and special information releases/statements, internal bimonthly reports, AVO email and internal electronic logs, and the Smithsonian Institution Global Volcanism Network Bulletins that are available at http://www.volcano.si.edu/ reports/bulletin/index.cfm.

Table 1 is a history of seismic monitoring of Alaskan volcanoes from August 1971 through December 2007. Table 2 summarizes 2007 volcanic activity in Alaska. Table 3 summarizes changes in Aviation Color Codes in 2007 for Alaskan volcanoes. Tables 4a, $\underline{4 b}$, and $\underline{4 c}$ present cross-referenced lists of volcanic activity by year and by volcano for all previous reports (1992-2006).

Only activity that resulted in a significant investment of staff time (defined here as several hours or more for reaction, tracking, and follow-up) is included. Where more extensive published documentation for an episode of unrest exists, we provide key references. Over the course of the year, AVO typically receives dozens of reports of steaming, unusual cloud sightings, or false eruption reports. Most of these are resolved very quickly and are not tabulated here as part of the response record; however, a section has been added to post selected information that was retroactively deemed worthwhile to include in this report.

On rare occasions, AVO issues an information release (now statement) to dispel rumors of volcanic activity. In years past, we have used the phrase "suspect volcanic activity" (SVA) to characterize unusual activity that is subsequently determined to be normal or merely enhanced fumarolic activity, weather-related phenomena, or other non-volcanic events. Beginning with the 2006 report, we have ceased using this term as it has presented us with problems of consistency.

Altitudes and elevations reported are in feet and/or meters above sea level (ASL) unless noted, and time is reported as Alaska Standard Time (AKST), Alaska Daylight Time (AKDT), Kamchatkan Standard Time (KST), or Kamchatkan Daylight Time (KDT) as needed, with Coordinated Universal Time (UTC) in parentheses. For most satellite or geophysical instrumentation references, times are given in UTC. We preserve English or Inch-Pound units of measurement especially where they reflect the primary observations of distance or altitude such as those commonly received via pilot reports and aviation authorities in the United States. Elsewhere, measurements are presented in International System of Units (SI) with Inch-Pound Units in parentheses for convenience. Volcano locations in latitude and longitude and summit elevations are taken from the Alaska Volcano Observatory database and may differ slightly from previously published compilations. 


\title{
ALASKA VOLCANO OBSERVATORY
}

\author{
Information Release
}

Thursday, November 8, 2007 2:25 PM AKST (2325 UTC)

\section{AVO IMPLEMENTS NEW VOLCANO HAZARD NOTIFICATIONS FOR VOLCANIC ACTIVITY}

The Alaska Volcano Observatory is implementing a new format for written notices of volcanic activity.

AVO will now issue a Volcanic Activity Notice (VAN) to announce eruptions, other significant activity, and alert level and color code changes for Alaskan volcanoes. For our aviation customers, a Volcano Observatory Notification for Aviation (VONA) will be offered. Daily status reports and weekly summaries will remain largely unchanged. Information Releases will be replaced by Information Statements.

These messages will be available via an e-mail subscription service at some time in the near future. They will also be posted to our web site.

The intent of this change is to provide a clearer and more consistent statement of volcano hazard information. It is our hope that the more structured format of the VAN and VONA will enable users to more quickly find the hazard content of most interest.

We will evaluate these new message protocols over the next several months and make changes as needed.

\section{AVO VOLCANO INFORMATION PRODUCTS}

VAN: Volcanic Activity Notice

Important announcement of volcanic activity or significant change in activity, aviation color code, or alert level.

VONA: Volcano Observatory Notice for Aviation

Highly formatted message focusing on ash cloud hazards.

DAILY STATUS REPORT:

Short statement on the status of volcanoes at elevated aviation color code or alert level.

WEEKLY SUMMARY:

A recap of activity over the past week and current status of monitored volcanoes.

INFORMATION STATEMENT:

Expanded background information, hazard scenarios, announcements of new monitoring benchmarks, etc.

Please see http://www.avo.alaska.edu/color codes.php for a complete description of alert levels and color codes.

VOLCANO INFORMATION ON THE INTERNET: http://www.avo.alaska.edu RECORDING ON THE STATUS OF ALASKA'S VOLCANOES (907) 786-7478

\section{CONTACT INFORMATION:}

Tom Murray Scientist-in-Charge, USGS

tlmurray@usgs.gov (907) 786-7497

Steve McNutt, Coordinating Scientist, UAF

steve@giseis.alaska.edu (907) 474-7131

The Alaska Volcano Observatory is a cooperative program of the U.S. Geological Survey, the University of Alaska Fairbanks Geophysical Institute, and the Alaska Division of Geological and Geophysical Surveys.

Figure 2. Alaska Volcano Observatory Information Release, Thursday, November 8, 2007, announcing the implementation of new volcano hazard notifications for volcanic activity. . 


\section{Volcano Alert Levels}

\section{NORMAL}

Volcano is in typical background, noneruptive state or, after a change from a higher level, volcanic activity has ceased and volcano has returned to noneruptive background state.

\section{ADVISORY}

Volcano is exhibiting signs of elevated unrest above known background level or, after a change from a higher level, volcanic activity has decreased significantly but continues to be closely monitored for possible renewed increase.

\section{WATCH}

Volcano is exhibiting heightened or escalating unrest with increased potential of eruption, timeframe uncertain, OR eruption is underway but poses limited hazards.

\section{WARNING}

Hazardous eruption is imminent, underway, or suspected.

UNASSIGNED

\section{Aviation Color Codes}

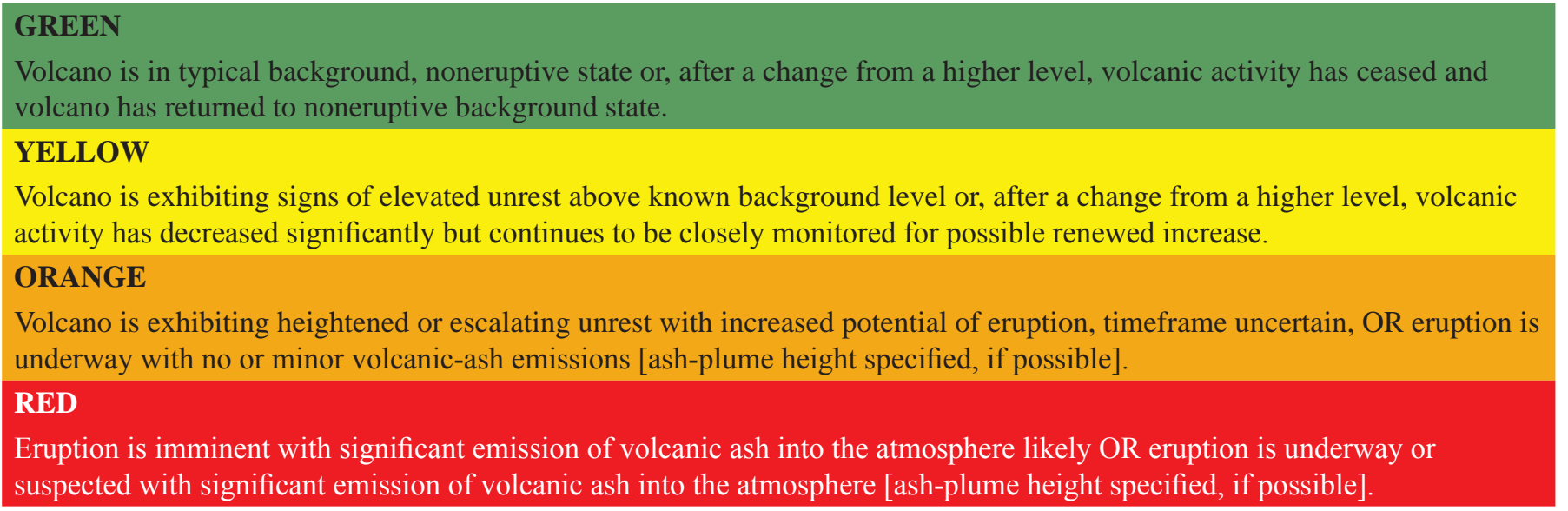

Figure 2. Alaska Volcano Observatory Information Release, Thursday, November 8, 2007, announcing the implementation of new volcano hazard notifications for volcanic activity.-Continued 


\section{SAMPLE USGS VOLCANIC ACTIVITY NOTICE}

Volcano: AUGUSTINE (CAVW\#1103-1)

Current Alert Level: WARNING

Previous Alert Level: WATCH

Current Aviation Colour Code: RED

Previous Aviation Colour Code: ORANGE

Issued: $\quad 20060111 / 1840 Z$

Source: $\quad$ Alaska Volcano Observatory

Notice number: $\quad 2006 / x x x A$

Location: $\quad$ N 59 deg $22 \mathrm{~min}, \mathrm{~W} 153 \mathrm{deg} 26 \mathrm{~min}$

Elevation: $\quad 4108 \mathrm{ft}(1252 \mathrm{~m})$

Area: $\quad$ Cook Inlet, Alaska, USA

Volcanic Activity Summary: Two brief eruptive explosions occurred at Augustine volcano this morning at $1344 Z$ and $1413 Z$ (4:44 a.m. and 5:13 a.m. AKST). Satellite data confirm an ash cloud was produced.

Recent Observations: [Monitoring report subfield] Seismicity has decreased significantly since the explosions but it is likely that stronger seismicity and further volcanic activity will resume. [Obs. Cloud Ht. subfield] Cloud height of $30,000 \mathrm{ft}(9400 \mathrm{~m})$ above AMSL is estimated from NWS satellite data. [Other cloud info subfield] The ash plume has detached and is drifting to the east of Augustine. As of $1640 Z$ (7:40 a.m. AKST), the ash cloud had traveled $200 \mathrm{mi}(124 \mathrm{~km})$ east.

Hazard Analysis: [General subfield] If the volcano follows a pattern similar to the 1976 and 1986 eruptions, we would expect a further intensification of seismic activity prior to similar or larger explosive events. [Ash cloud subfield] It is possible that additional ash-producing explosive eruptions could occur with little or no warning. [Ashfall subfield] An ashfall advisory was issued by the NWS at $1544 Z$ (6:44 a.m. AKST). [Tsunami subfield] There is no tsunami hazard associated with the current activity.

Remarks: AVO website at http://www.avo.alaska.edu

NOAA National Weather Service: ash cloud trajectories and aviation warnings at http://pafc.arh.noaa.gov/augustine.php

NOAA West Coast/Alaska tsunami warning center messages at

http://wcatwc.arh.noaa.gov/augustine/augustineweb.htm

Contacts: Tom Murray, Scientist-in-Charge, USGS, tImurray@usgs.gov (907) 786-7497.

Steve McNutt, Acting Coordinating Scientist, UAFGI, steve@giseis.alaska.edu (907) 474-7131 or (907) 474-7274

Next Notice: A new Volcanic Activity Notice (VAN) will be issued when conditions at the volcano warrant changing the alert level and aviation color code or when a significant volcanic event occurs at this alert level. While a VAN is in effect, daily/hourly/weekly (choose one) updates are posted at http://www.avo.alaska.edu

Figure 3. Samples of the new Volcanic Activity Notice (VAN) and Volcanic Activity Notice for Aviation (VONA). 


\section{SAMPLE USGS VOLCANIC ACTIVITY NOTICE FOR AVIATION}

(1)

(2)

(3)

(4)

(5)

(6)

(7)

(8)

(9)

(14) Remarks:

(15)

(16)

Issued:

Volcano:

Source:

Area:

Contacts:

\section{VOLCANO OBSERVATORY NOTICE FOR AVIATION}

Current Avaiation Color Code:

Previous Aviation Color Code:

Notice Number:

Volcano Location:

Summit Elevation:

Volcanic Activity Summary:

Volcanic Cloud Height:

Other Cloud Information:

Next Notice:

RED

ORANGE

2006/xxxA
$20060222 / 2840 Z$

Augustine (CAVW\#1103-1)

Alaska Volcano Observatory

5922N15326W

Cook Inlet, Alaska, USA

4108 FT (1252 M)

Two brief eruptive explosions occurred at Augustine volcano this morning at 1344Z and 1413Z (4:44 a.m. and 5:13 a.m. AKST). Satellite data confirm an ash cloud was produced.

Cloud height of 30,000 ft (9400 m) above AMSL is estimated from NWS satellite data.

Ash cloud is detached from the volcano and moving east over the southern Kenai Peninsula and Gulf of Alaska. An ashfall advisory was issued by NWS at 1544Z (6:44 a.m. AKST). For impact on aircraft operations see current SIGMET, CWA, VAA, and PIREP information.

Additional sudden explosions are likely based on past eruptive history. AVO would expect a significant increase in seismicity prior to larger or more sustained ash production.

Tom Murray, Scientist-in-Charge, USGS, tlmurray@usgs.gov (907) 786-7497.

Steve McNutt, Acting Coordinating Scientist, UAFGI, steve@giseis.alaska.edu (907) 474-7131 or (907) 474-7274

Will be issued when conditions at the volcano warrant changing the aviation color code or when a significant volcanic event occurs within the current color code.

Figure 3. Samples of the new Volcanic Activity Notice (VAN) and Volcanic Activity Notice for Aviation (VONA).-Continue 
Table 2. Summary of 2007 VOLCANIC ACTIVITY in Alaska, including actual eruptions, possible eruptions, unusual increases in seismicity or fumarolic activity.

[Location of volcanoes shown in figure 1]

\begin{tabular}{|c|c|c|}
\hline Volcano & Date of activity & Type of activity \\
\hline Redoubt & February, May 2007 & Possible steaming and first evidence of thermal flux to summit \\
\hline Fourpeaked & January 1-June 2007 & Sporadic seismicity, minor phreatic emissions (possibly with ash) and vapor plumes \\
\hline Veniaminof & January 2007 & Gradual decline in emission of vapor plumes; drop in Color Code \\
\hline Cleveland & Intermittently throughout 2007 & $\begin{array}{l}\text { Intermittent explosions, thermal anomalies, minor ash and gas emission, flowage } \\
\text { and ballistic deposits }\end{array}$ \\
\hline Korovin & Intermittently through August 2007 & Seismic swarms, continued fumarolic activity, inflation rate decreases \\
\hline
\end{tabular}

Table 3. Alaskan volcanoes with Color Code changes in 2007.

[Description of Aviation Level of Concern Color Codes is shown in appendix 1. Local times are only shown where color code changes were short-lived during rapidly evolving events. Volcanoes that do not have a realtime seismic network are not assigned a color code GREEN because without seismic data, Alaska Volcano Observatory has no definitive information that the level of activity at the volcano is at background. For these volcanoes, AVO uses the designation UNASSIGNED]

\begin{tabular}{|l|c|}
\hline \multicolumn{1}{|c|}{ Color Code } & DUGUSTINE \\
\hline \multicolumn{2}{|c|}{ Fo change } \\
\hline GREEN & January 1-September 22 \\
\hline YELLOW & September 22-October 12 \\
\hline GREEN & October 12-December 31 \\
\hline \multicolumn{2}{|c|}{ FOUEAKED } \\
\hline YELLOW & January 1-June 6 \\
\hline GREEN & June 6-December 31 \\
\hline \multicolumn{2}{|c|}{ VENIAMINOF } \\
\hline YELLOW & January 1-April 26 \\
\hline GREEN & April 26-December 31 \\
\hline \multicolumn{2}{|c|}{ PAVLOF } \\
\hline GREEN & January 1-August 14 \\
\hline YELLOW & August 14-August 15 \\
\hline ORANGE & August 15-September 20 \\
\hline YELLOW & September 20-October 5 \\
\hline GREEN & October 5-December 31 \\
\hline \multicolumn{2}{|c|}{ CLEVELAND } \\
\hline YELLOW & January 1-July 20 \\
\hline ORANGE & July 20-September 6 \\
\hline YELLOW & September 6-December 31 \\
\hline \multicolumn{2}{|c|}{ KOROVIN } \\
\hline YELLOW & January 1-September 7 \\
\hline GREEN & September 7-December 31 \\
\hline
\end{tabular}


Table 4a. Compilation by year of volcanoes included in an Alaska Volcano Observatory Annual Summary, $1992-2007$.

[Volcanoes are presented in geographical order from northeast to southwest along the Wrangell-Aleutian volcanic arc and north to south along Kamchatka and the Kurile Islands. Prior to 1995, Alaska Volcano Observatory did not report on Russian volcanoes]

\begin{tabular}{lc}
\hline \multicolumn{1}{c}{ Volcanoes mentioned } \\
\hline \multicolumn{1}{c}{ Alaskan } & \multicolumn{1}{c}{ Russian } \\
\hline Spurr/Crater Peak & \\
Iliamna \\
Redoubt \\
Mageik (Katmai Group) \\
Westdahl \\
Akutan \\
Bogoslof \\
Seguam \\
\hline \\
\hline Churchill \\
Sanford \\
Spurr/Crater Peak \\
Veniaminof \\
Shishaldin \\
Makushin \\
Seguam \\
Kliuchef (Atka) \\
Kanaga \\
\hline \\
\end{tabular}

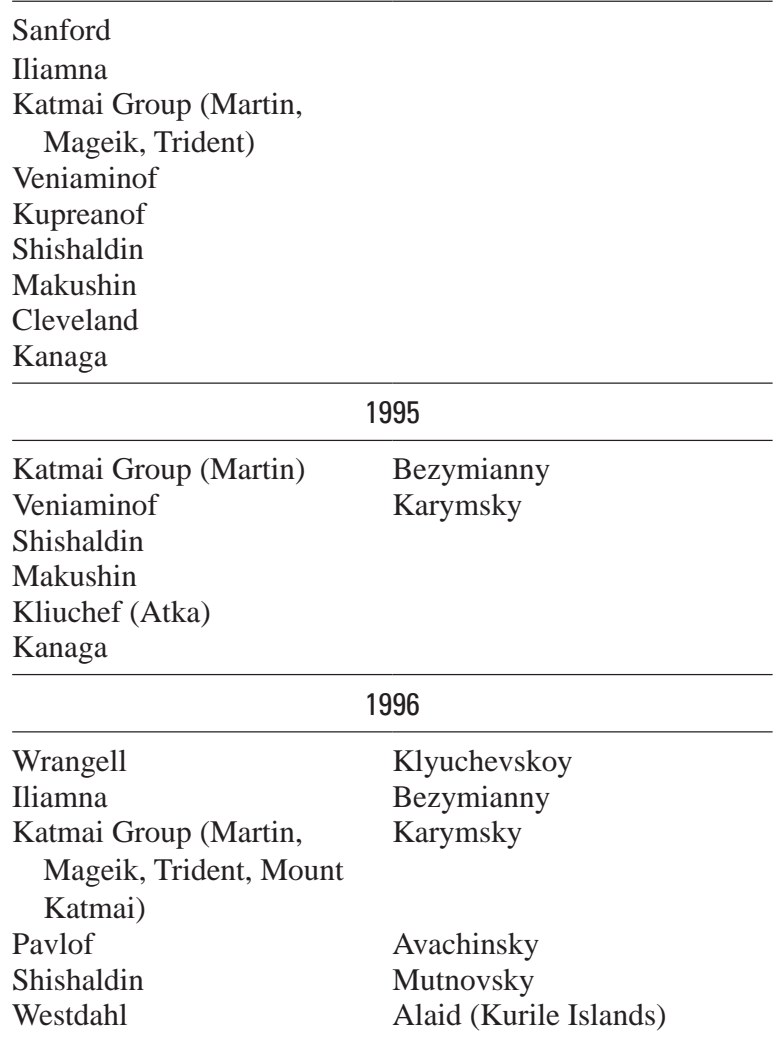

\begin{tabular}{cc}
\hline \multicolumn{2}{c}{ Volcanoes mentioned } \\
\hline Alaskan & Russian \\
\hline \multicolumn{2}{c}{1996 - Continued }
\end{tabular}

\begin{tabular}{l} 
Akutan \\
Amukta \\
Korovin (Atka) \\
Kanaga \\
\hline \\
\hline Wrangell \\
Sanford \\
Shrub Mud \\
Iliamna \\
Katmai Group (Martin, \\
$\quad$ Mageik, Snowy, Kukak) \\
Chiginagak \\
Pavlof \\
Shishaldin \\
Okmok \\
Cleveland \\
Amukta
\end{tabular}

\begin{tabular}{|c|c|}
\hline \multicolumn{2}{|c|}{1998} \\
\hline $\begin{array}{l}\text { Shrub Mud } \\
\text { Augustine } \\
\text { Becharof Lake } \\
\text { Chiginagak } \\
\text { Shishaldin } \\
\text { Akutan } \\
\text { Korovin (Atka) }\end{array}$ & $\begin{array}{l}\text { Sheveluch } \\
\text { Klyuchevskoy } \\
\text { Bezymianny } \\
\text { Karymsky }\end{array}$ \\
\hline \multicolumn{2}{|c|}{1999} \\
\hline $\begin{array}{l}\text { Wrangell } \\
\text { Shrub Mud } \\
\text { Iliamna } \\
\text { Veniaminof } \\
\text { Pavlof } \\
\text { Shishaldin } \\
\text { Vsevidof }\end{array}$ & $\begin{array}{l}\text { Sheveluch } \\
\text { Klyuchevskoy } \\
\text { Bezymianny } \\
\text { Karymsky }\end{array}$ \\
\hline \multicolumn{2}{|c|}{2000} \\
\hline $\begin{array}{l}\text { Wrangell } \\
\text { Katmai Group (Snowy) } \\
\text { Chiginagak } \\
\text { Shishaldin }\end{array}$ & $\begin{array}{l}\text { Sheveluch } \\
\text { Klyuchevskoy } \\
\text { Bezymianny } \\
\text { Karymsky } \\
\text { Mutnovsky }\end{array}$ \\
\hline \multicolumn{2}{|c|}{2001} \\
\hline $\begin{array}{l}\text { Katmai Group } \\
\text { (Snowy/Kukak) } \\
\text { Pavlof } \\
\text { Frosty } \\
\text { Shishaldin }\end{array}$ & $\begin{array}{l}\text { Sheveluch } \\
\text { Klyuchevskoy } \\
\text { Bezymianny } \\
\text { Karymsky }\end{array}$ \\
\hline
\end{tabular}


Table 4a. Compilation by year of volcanoes included in an Alaska Volcano Observatory Annual Summary, 1992-2007.Continued

[Volcanoes are presented in geographical order from northeast to southwest along the Wrangell-Aleutian volcanic arc and north to south along Kamchatka and the Kurile Islands. Prior to 1995, Alaska Volcano Observatory did not report on Russian volcanoes]

\begin{tabular}{|c|c|c|c|}
\hline \multicolumn{2}{|c|}{ Volcanoes mentioned } & \multicolumn{2}{|c|}{ Volcanoes mentioned } \\
\hline Alaskan & Russian & Alaskan & Russian \\
\hline \multicolumn{2}{|c|}{ 2001-Continued } & \multicolumn{2}{|c|}{2005} \\
\hline Makushin & \multirow[t]{4}{*}{ Avachinsky } & Mount Spurr & \multirow{4}{*}{$\begin{array}{l}\text { Sheveluch } \\
\text { Klyuchevskoy } \\
\text { Bezymianny } \\
\text { Karymsky }\end{array}$} \\
\hline Okmok & & Iliamna & \\
\hline Cleveland & & Augustine & \\
\hline Great Sitkin & & Katmai Group (Martin, & \\
\hline \multicolumn{2}{|c|}{2002} & $\begin{array}{l}\text { Mageik, Trident) } \\
\text { Chiginagak }\end{array}$ & \multirow{9}{*}{$\begin{array}{l}\text { Avachinsky } \\
\text { Mutnovsky } \\
\text { Ebeko } \\
\text { Chikurachki }\end{array}$} \\
\hline Wrangell & Sheveluch & Aniakchak & \\
\hline Katmai Group (Martin, & Klyuchevskoy & Veniaminof & \\
\hline Mageik) & \multirow{6}{*}{$\begin{array}{l}\text { Bezymianny } \\
\text { Karymsky }\end{array}$} & Pavlof/Mt. Hague & \\
\hline Veniaminof & & Shishaldin & \\
\hline Mt. Hague (Emmons & & Cleveland & \\
\hline Lake Caldera) & & Korovin & \\
\hline Shishaldin & & Kasatochi & \\
\hline Great Sitkin & & Tanaga & \\
\hline \multicolumn{2}{|c|}{2003} & \multicolumn{2}{|c|}{2006} \\
\hline Wrangell & \multirow{11}{*}{$\begin{array}{l}\text { Sheveluch } \\
\text { Klyuchevskoy } \\
\text { Bezymianny } \\
\text { Karymsky } \\
\text { Alaid } \\
\text { Chikurachki }\end{array}$} & Klawasi & \multirow{6}{*}{$\begin{array}{l}\text { Sheveluch } \\
\text { Klyuchevskoy } \\
\text { Bezymianny } \\
\text { Karymsky } \\
\text { Ebeko }\end{array}$} \\
\hline Redoubt & & Mount Spurr & \\
\hline Iliamna & & Augustine & \\
\hline Augustine & & Fourpeaked & \\
\hline Katmai Group (Mageik) & & Katmai Group (Martin, & \\
\hline Veniaminof & & Mageik, Trident) & \\
\hline Pavlof & & Veniaminof & \multirow{4}{*}{$\begin{array}{l}\text { Severgin } \\
\text { Berga }\end{array}$} \\
\hline Mt. Hague (Emmons & & Cleveland & \\
\hline Lake Caldera) & & Korovin & \\
\hline Shishaldin & & Kasatochi & \\
\hline Akutan & & \multicolumn{2}{|c|}{2007} \\
\hline \multicolumn{2}{|c|}{2004} & \multirow{9}{*}{$\begin{array}{l}\text { Wrangell } \\
\text { Redoubt } \\
\text { Augustine } \\
\text { Fourpeaked } \\
\text { Veniaminof } \\
\text { Pavlof } \\
\text { Akutan } \\
\text { Cleveland } \\
\text { Korovin }\end{array}$} & \multirow{3}{*}{$\begin{array}{l}\text { Sheveluch } \\
\text { Klyuchevskoy } \\
\text { Bezymianny }\end{array}$} \\
\hline Mt. Crillon (non-volcanic & Sheveluch & & \\
\hline peak) & & & \\
\hline Mount Spurr & Klyuchevskoy & & Gorely and Mutnovsky \\
\hline Katmai Group (Martin) & Bezymianny & & \\
\hline Veniaminof & Karymsky & & Chikurachki \\
\hline Shishaldin & Chirinkotan (Kuriles) & & Berga \\
\hline Westdahl & & & \\
\hline & & & \\
\hline
\end{tabular}


Table 4b. Compilation by volcano for particular years included in an Alaska Volcano Observatory Annual Summary, 1992-2007.

[Suspect Volcanic Activity (SVA) is defined as a report of eruption or possible eruption that is normal fumarolic activity or non-volcanic phenomena, such as weather related. PIREP, pilot weather report. AVO stopped using this designation in 2006]

\begin{tabular}{|c|c|c|}
\hline Volcano & Year mentioned & Type of activity \\
\hline \multicolumn{3}{|c|}{ Alaska (east to west) } \\
\hline Churchill & 1993 & SVA, anomalous seismicity \\
\hline Wrangell & $\begin{array}{l}1996 \\
1997 \\
1999 \\
2000 \\
2002 \\
2003 \\
2007\end{array}$ & $\begin{array}{l}\text { SVA, steam plume } \\
\text { SVA, steam plume } \\
\text { SVA, steaming and phreatic ash emission } \\
\text { SVA, steam plumes } \\
\text { SVA, suspicious clouds, redistributed ash } \\
\text { SVA, anomalous clouds } \\
\text { Triggered seismicity; steam plumes and redistributed ash }\end{array}$ \\
\hline Sanford & $\begin{array}{l}1993 \\
1994 \\
1997\end{array}$ & $\begin{array}{l}\text { SVA, reported steam plume likely from avalanche } \\
\text { SVA, reported steam plume likely from avalanche } \\
\text { SVA, large steam cloud from SW face }\end{array}$ \\
\hline Shrub Mud & $\begin{array}{l}1997 \\
1998 \\
1999\end{array}$ & $\begin{array}{l}\text { Eruption; energetic ejection of saline mud and } \mathrm{CO}_{2} \\
\text { Eruption continues; saline mud and } \mathrm{CO}_{2} \text { ejected } \\
\text { Eruption continues; saline mud and } \mathrm{CO}_{2} \text { emission }\end{array}$ \\
\hline Klawasi Mud & 2006 & Possible new mud vent \\
\hline Spurr & $\begin{array}{l}1992 \\
1993 \\
2004 \\
2005 \\
2006\end{array}$ & $\begin{array}{l}\text { Subplinian eruptions; ash, pyroclastic flows, lahars } \\
\text { SVA, glacial outburst produces seismicity } \\
\text { Heat flux to summit; lahars; cauldron develops } \\
\text { Continued heat to summit; cauldron evolves } \\
\text { Continued heat to summit; cauldron evolves }\end{array}$ \\
\hline Redoubt & $\begin{array}{l}1992 \\
2003 \\
2007\end{array}$ & $\begin{array}{l}\text { SVA, steam plume from still-cooling dome } \\
\text { SVA, anomalous weather cloud } \\
\text { First signs of precursory activity leading to } 2009 \text { eruption }\end{array}$ \\
\hline Iliamna & $\begin{array}{l}1992 \\
1994 \\
1996 \\
1997 \\
1999 \\
2003 \\
2005\end{array}$ & $\begin{array}{l}\text { SVA, PIREP of large steam plume, media frenzy } \\
\text { SVA, vigorous steam plume, avalanche } \\
\text { Intense seismicity related to magmatic intrusion } \\
\text { SVA; anomalous seismic swarm; avalanche } \\
\text { SVA, avalanche } \\
\text { SVA, avalanche } \\
\text { SVA, rock avalanche }\end{array}$ \\
\hline Augustine & $\begin{array}{l}1998 \\
2005 \\
2006 \\
2007\end{array}$ & $\begin{array}{l}1986 \text { dome spine partially collapses, generates mudflow } \\
\text { Precursory activity prior to eruption in early } 2006 \\
\text { Explosive and effusive eruption } \\
\text { Strong seismic events; reports of steam plumes }\end{array}$ \\
\hline Fourpeaked & $\begin{array}{l}2006 \\
2007\end{array}$ & $\begin{array}{l}\text { Phreatic eruption } \\
\text { Ongoing fumarolic emissions }\end{array}$ \\
\hline
\end{tabular}


Table 4b. Compilation by volcano for particular years included in an Alaska Volcano Observatory Annual Summary, 1992-2007.-Continued

[Suspect Volcanic Activity (SVA) is defined as a report of eruption or possible eruption that is normal fumarolic activity or non-volcanic phenomena, such as weather related. PIREP, pilot weather report. AVO stopped using this designation in 2006]

\begin{tabular}{|c|c|c|}
\hline Volcano & Year mentioned & Type of activity \\
\hline \multicolumn{3}{|c|}{ Alaska (east to west)—Continued } \\
\hline \multicolumn{3}{|l|}{ Katmai Group } \\
\hline Mageik & 1992 & SVA, anomalous cloud \\
\hline Martin/Mageik/Trident & 1994 & SVA, plume-like cloud \\
\hline Martin & 1995 & SVA, large steam plume \\
\hline Martin/Mageik/Trident/Mount Katmai & 1996 & SVA, anomalous seismicity \\
\hline Martin/Mageik/Snowy/Kukak & 1997 & SVA, PIREPS of ash and steam plumes \\
\hline Snowy & 2000 & SVA, steaming hole in glacier \\
\hline Snowy/Kukak & 2001 & SVA, steaming hole in glacier \\
\hline Martin/Mageik & 2002 & SVA, steam plume \\
\hline Mageik & 2003 & SVA, steaming, large cloud of re-suspended ash \\
\hline Martin & 2004 & SVA, large steam plume \\
\hline Martin & 2006 & Earthquake swarm \\
\hline Martin/Mageik/Trident & 2005 & SVA, steam cloud, re-suspended ash, new crater? \\
\hline Becharof Lake & 1998 & SVA, intense seismic swarm and inflationary episode \\
\hline \multirow[t]{4}{*}{ Chiginagak } & 1997 & Minor eruptive activity, new fumarole field \\
\hline & 1998 & SVA, continuation of increased fumarolic activity \\
\hline & 2000 & SVA, steam emissions from fumarole field \\
\hline & 2005 & Heat to summit; acidic flood; cauldron develops \\
\hline Aniakchak & 2005 & SVA, anomalous seismicity, thermal anomaly \\
\hline \multirow[t]{10}{*}{ Veniaminof } & 1993 & Low-level eruption and lava flows \\
\hline & 1994 & Strombolian eruption and lava flows \\
\hline & 1995 & Strombolian eruptions \\
\hline & 1999 & SVA, extreme discharge and turbid river \\
\hline & 2002 & Low-level phreatic eruptions \\
\hline & 2003 & Low-level phreatic eruptions \\
\hline & 2004 & Weak phreatic and Strombolian eruption \\
\hline & 2005 & Intermittent phreatic and Strombolian eruption \\
\hline & 2006 & Intermittent phreatic and Strombolian eruption \\
\hline & 2007 & Weak phreatic emissions and vapor plumes \\
\hline Kupreanof & 1994 & SVA, PIREP of unusual steam plume \\
\hline \multirow[t]{6}{*}{ Pavlof } & 1996 & Strombolian eruption \\
\hline & 1997 & Strombolian eruption concludes \\
\hline & 1999 & SVA, summit snow melt, ash dustings, steam plumes \\
\hline & 2001 & SVA, steaming, possible ash, sulfur smell \\
\hline & 2005 & SVA, mis-located steam plume \\
\hline & 2007 & Strombolian eruption \\
\hline \multirow[t]{3}{*}{ Hague (Emmons Lake Caldera) } & 2002 & SVA, increase in fumarolic activity in summit crater \\
\hline & 2003 & SVA, crater lake drains, refills, drains \\
\hline & 2005 & SVA, steam plume \\
\hline Frosty & 2001 & SVA, rock fall avalanches \\
\hline
\end{tabular}


Table 4b. Compilation by volcano for particular years included in an Alaska Volcano Observatory Annual Summary, 1992-2007.-Continued

[Suspect Volcanic Activity (SVA) is defined as a report of eruption or possible eruption that is normal fumarolic activity or non-volcanic phenomena, such as weather related. PIREP, pilot weather report. AVO stopped using this designation in 2006]

\begin{tabular}{|c|c|c|}
\hline Volcano & Year mentioned & Type of activity \\
\hline \multicolumn{3}{|c|}{ Alaska (east to west)—Continued } \\
\hline \multirow[t]{13}{*}{ Shishaldin } & 1993 & Minor phreatic \\
\hline & 1994 & SVA, PIREP of minor steam/ash \\
\hline & 1995 & Minor eruptive activity, steam/ash \\
\hline & 1996 & Eruption; steam/ash and thermal anomaly \\
\hline & 1997 & Minor eruptive activity, steam/ash \\
\hline & 1998 & Minor eruptive activity, steam/ash \\
\hline & 1999 & Strombolian eruption \\
\hline & 2000 & Minor eruptive activity, steam/ash \\
\hline & 2001 & Minor unrest, seismicity increase, steam clouds \\
\hline & 2002 & SVA, shallow seismicity; PIREP of possible eruption \\
\hline & 2003 & SVA, steam plumes \\
\hline & 2004 & Small steam and ash plumes \\
\hline & 2005 & SVA, increased seismicity, steam plumes prompt PIREPS \\
\hline \multirow[t]{3}{*}{ Westdahl } & 1992 & Fissure eruption, lava fountains, ash clouds, lava flow \\
\hline & 1996 & SVA, suspicious weather cloud on satellite image \\
\hline & 2004 & SVA, seismic swarm \\
\hline \multirow[t]{5}{*}{ Akutan } & 1992 & SVA, steam/ash emissions \\
\hline & 1996 & Intensive seismicity, ground cracking \\
\hline & 1998 & SVA, tremor-like seismicity \\
\hline & 2003 & SVA, anomalous steam plume \\
\hline & 2007 & Triggered seismicity; inflation; anomalous steaming on lower east flank \\
\hline \multirow[t]{4}{*}{ Makushin } & 1993 & Minor phreatic \\
\hline & 1994 & SVA, PIREP of minor steam/ash \\
\hline & 1995 & SVA, steam plume \\
\hline & 2001 & SVA, increase in seismicity \\
\hline Bogoslof & 1992 & Dome extrusion, ash and steam emissions \\
\hline \multirow[t]{2}{*}{ Okmok } & 1997 & Strombolian eruption \\
\hline & 2001 & SVA, seismic swarm \\
\hline Vsevidof & 1999 & SVA, sighting of ash after regional earthquake \\
\hline \multirow[t]{6}{*}{ Cleveland } & 1994 & SVA, possible steam/ash emission \\
\hline & 1997 & Minor eruption, steam/ash \\
\hline & 2001 & Eruption; gas/ash, lava/debris flows \\
\hline & 2005 & Intermittent explosions \\
\hline & 2006 & Intermittent explosions \\
\hline & 2007 & Intermittent explosions, small ash clouds \\
\hline \multirow[t]{2}{*}{ Amukta } & 1996 & Small eruption; ash emission \\
\hline & 1997 & SVA, PIREP of small ash eruption \\
\hline \multirow[t]{2}{*}{ Seguam/Pyre Peak } & 1992 & Minor eruptive activity, steam/ash emissions \\
\hline & 1993 & Fissure eruption produces lava flow and ash cloud \\
\hline \multirow[t]{2}{*}{ Kliuchef (Atka) } & 1993 & SVA, audible rumbling, strong sulfur odor \\
\hline & 1995 & SVA, large steam plume, strong sulfur odor \\
\hline \multirow[t]{5}{*}{ Korovin (Atka) } & 1996 & SVA, PIREP of ash cloud, suspicious cloud on satellite image \\
\hline & 1998 & Eruption; explosions and ash fall \\
\hline & 2005 & Minor eruption, steam and ash \\
\hline & 2006 & Seismic swarms, uplift, increased fumarolic activity \\
\hline & 2007 & Seismic swarms, continued fumarolic activity, inflation rate decreases \\
\hline
\end{tabular}


Table 4b. Compilation by volcano for particular years included in an Alaska Volcano Observatory Annual Summary, 1992-2007.-Continued

[Suspect Volcanic Activity (SVA) is defined as a report of eruption or possible eruption that is normal fumarolic activity or non-volcanic phenomena, such as weather related. PIREP, pilot weather report. AVO stopped using this designation in 2006]

\begin{tabular}{|c|c|c|}
\hline Volcano & Year mentioned & Type of activity \\
\hline \multicolumn{3}{|c|}{ Alaska (east to west)—Continued } \\
\hline Kasatochi & $\begin{array}{l}2005 \\
2006\end{array}$ & $\begin{array}{l}\text { SVA, unusual bubbling; floating scum on crater lake } \\
\text { Continued bubbling in intracaldera lake }\end{array}$ \\
\hline Great Sitkin & $\begin{array}{l}2001 \\
2002\end{array}$ & $\begin{array}{l}\text { SVA, anomalous seismicity } \\
\text { SVA, seismic swarm, tremor }\end{array}$ \\
\hline Kanaga & $\begin{array}{l}1993 \\
1994 \\
1995 \\
1996\end{array}$ & $\begin{array}{l}\text { SVA, increased steaming } \\
\text { Eruption; steam/ash and lava flow } \\
\text { Minor eruptive activity, steam/ash and lava } \\
\text { Possible eruption and ash emission }\end{array}$ \\
\hline Tanaga & 2005 & SVA, anomalous seismicity, including a period of tremor \\
\hline \multicolumn{3}{|c|}{ Kamchatka and northern Kurile Islands (north to south) } \\
\hline Sheveluch & $\begin{array}{l}1997 \\
1998 \\
1999 \\
2000 \\
2001 \\
2002 \\
2003 \\
2004 \\
2005 \\
2006 \\
2007\end{array}$ & $\begin{array}{l}\text { Dome extrusion } \\
\text { Lava dome growth } \\
\text { Lava dome growth and collapse, ash } \\
\text { Lava dome growth, ash } \\
\text { Lava dome growth and collapse, ash } \\
\text { Lava dome growth, ash, pyroclastic flows } \\
\text { Lava dome growth, ash, pyroclastic flows, lahar } \\
\text { Lava dome growth, pyroclastic flows, lahars, ash } \\
\text { Lava dome growth, dome collapse, pyroclastic flows, ash } \\
\text { Lava dome growth, dome collapse, explosions } \\
\text { Lava dome growth, dome collapse, explosions, ash plumes, avalanches }\end{array}$ \\
\hline Klyuchevskoy & $\begin{array}{l}1996 \\
1997 \\
1998 \\
1999 \\
2000 \\
2001 \\
2002 \\
2003 \\
2004 \\
2005 \\
2006 \\
2007\end{array}$ & $\begin{array}{l}\text { Gas/ash eruption } \\
\text { Gas/ash eruption } \\
\text { Gas/ash eruption } \\
\text { Gas/ash eruption } \\
\text { Vulcanian explosions } \\
\text { Fumarolic plume } \\
\text { Elevated seismicity, gas-rich explosion } \\
\text { Elevated seismicity, ash explosion, Strombolian activity } \\
\text { Elevated seismicity } \\
\text { Strombolian eruption, lava flows, lahars } \\
\text { Increased seismicity, thermal anomaly, no eruption } \\
\text { Strombolian explosions, lava flow production }\end{array}$ \\
\hline \multicolumn{3}{|c|}{ Kamchatka and northern Kurile Islands (north to south) —Continued } \\
\hline Bezymianny & $\begin{array}{l}1995 \\
1996 \\
1997 \\
1998 \\
1999 \\
2000 \\
2001 \\
2002 \\
2003 \\
2004 \\
2005 \\
2006 \\
2007\end{array}$ & $\begin{array}{l}\text { Explosive eruption } \\
\text { Lava extrusion } \\
\text { Dome collapse and explosive eruption } \\
\text { Degassing and spalling of new dome } \\
\text { Degassing and spalling of new dome, ash } \\
\text { Dome growth, explosive eruption } \\
\text { Accelerated dome growth, pyroclastic flows } \\
\text { Accelerated dome growth, explosions, pyroclastic flows } \\
\text { Dome growth and explosive collapse } \\
\text { Minor explosive eruptions, gas and steam emissions } \\
\text { Dome growth continues, two explosive episodes } \\
\text { Dome growth continues, two explosive episodes } \\
\text { Intermittent lava dome growth and explosions }\end{array}$ \\
\hline
\end{tabular}


Table 4b. Compilation by volcano for particular years included in an Alaska Volcano Observatory Annual Summary, 1992-2007.-Continued

[Suspect Volcanic Activity (SVA) is defined as a report of eruption or possible eruption that is normal fumarolic activity or non-volcanic phenomena, such as weather related. PIREP, pilot weather report. AVO stopped using this designation in 2006]

\begin{tabular}{|c|c|c|}
\hline Volcano & Year mentioned & Type of activity \\
\hline \multirow[t]{13}{*}{ Karymsky } & 1995 & Increased seismicity \\
\hline & 1996 & Explosive eruption \\
\hline & 1997 & Low level Strombolian eruptions \\
\hline & 1998 & Low level Strombolian eruptions \\
\hline & 1999 & Low level Vulcanian and Strombolian eruptions \\
\hline & 2000 & Low level Vulcanian and Strombolian eruptions \\
\hline & 2001 & Low level Vulcanian and Strombolian eruptions \\
\hline & 2002 & Low level Vulcanian and Strombolian eruptions, explosions, avalanches \\
\hline & 2003 & Vulcanian and Strombolian eruptions intensify \\
\hline & 2004 & Low level Vulcanian and Strombolian eruptions \\
\hline & 2005 & $\begin{array}{l}\text { Low level Vulcanian and Strombolian eruptions, explosions, lava, ash } \\
\text { fall }\end{array}$ \\
\hline & 2006 & Low level Vulcanian and Strombolian eruptions \\
\hline & 2007 & Strombolian/Vulcanian eruption continues intermittently \\
\hline \multirow[t]{3}{*}{ Avachinsky } & 1996 & Increased seismicity \\
\hline & 2001 & Increased seismicity, phreatic explosion \\
\hline & 2005 & Increased seismicity, thermal anomalies \\
\hline \multirow[t]{4}{*}{ Mutnovsky } & 1996 & Fumarolic plume \\
\hline & 2000 & Gas and steam explosion \\
\hline & 2005 & Increased fumarolic activity \\
\hline & 2007 & Increased seismicity (source uncertain); fumarolic activity at Gorely \\
\hline \multirow[t]{2}{*}{ Alaid (Kurile Islands) } & 1996 & Ash plume \\
\hline & 1997 & SVA \\
\hline \multirow[t]{2}{*}{ Ebeko } & 2005 & Increased fumarolic activity and phreatic eruptions \\
\hline & 2006 & Increased fumarolic activity \\
\hline \multirow[t]{3}{*}{ Chikurachki } & 2003 & Strombolian and Vulcanian eruption, ash fall \\
\hline & 2005 & Brief explosion produces ash and ash fall \\
\hline & 2007 & Explosions and limited ash clouds \\
\hline Severgin & 2006 & Phreatic or fumarolic activity \\
\hline Chirinkotan & 2004 & Brief, low-level steam, gas, and ash emission \\
\hline \multirow[b]{2}{*}{ Berga } & 2006 & Phreatic or fumarolic activity \\
\hline & 2007 & Possible eruption and gas outburst \\
\hline
\end{tabular}


Table 4c. Citations for Alaska Volcano Observatory Annual Summary reports, 1992-2006.

\begin{tabular}{|c|c|c|}
\hline Year & Citation & URL \\
\hline 1992 & $\begin{array}{l}\text { McGimsey, R.G., Neal, C.A., and Doukas, M.P., 1995, Volcanic activity in Alaska: Summary } \\
\text { of events and response of the Alaska Volcano Observatory 1992: U.S. Geological Survey } \\
\text { Open-File Report 95-83, } 26 \text { p. }\end{array}$ & http://pubs.er.usgs.gov/usgspubs/ofr/ofr9583 \\
\hline 1993 & $\begin{array}{l}\text { Neal, C.A., McGimsey, R.G., and Doukas, M.P., 1996, } 1993 \text { volcanic activity in Alaska: } \\
\text { Summary of events and response of the Alaska Volcano Observatory: U.S. Geological } \\
\text { Survey Open-File Report 96-0024, } 21 \text { p. }\end{array}$ & http://geopubs.wr.usgs.gov/open-file/of96-24/ \\
\hline 1995 & $\begin{array}{l}\text { McGimsey, R.G., and Neal, C.A., 1996, } 1995 \text { Volcanic activity in Alaska and Kamchatka: } \\
\text { Summary of events and response of the Alaska Volcano Observatory: U.S. Geological } \\
\text { Survey Open-File Report 96-0738, } 22 \text { p. }\end{array}$ & $\underline{\text { http://geopubs.wr.usgs.gov/open-file/of96-738/ }}$ \\
\hline 1996 & $\begin{array}{l}\text { Neal, C.A., and McGimsey, R.G., 1997, } 1996 \text { Volcanic activity in Alaska and Kamchatka: } \\
\text { Summary of events and response of the Alaska Volcano Observatory: U.S. Geological } \\
\text { Survey Open-File Report 97-0433, } 34 \text { p. }\end{array}$ & $\underline{\text { http://geopubs.wr.usgs.gov/open-file/of97-433/ }}$ \\
\hline 1998 & $\begin{array}{l}\text { McGimsey, R.G., Neal, C.A., and Girina, Olga, 2003, } 1998 \text { Volcanic activity in Alaska and } \\
\text { Kamchatka: Summary of events and response of the Alaska Volcano Observatory: U.S. } \\
\text { Geological Survey Open-File Report 03-0423, } 35 \text { p. }\end{array}$ & http://pubs.usgs.gov/of/2003/of03-423/ \\
\hline 1999 & $\begin{array}{l}\text { McGimsey, R. G., Neal, C. A., and Girina, Olga, 2004a, } 1999 \text { Volcanic activity } \\
\text { in Alaska and Kamchatka: Summary of events and response of the Alaska Volcano } \\
\text { Observatory: U.S. Geological Survey Open-File Report OF 2004-1033, } 49 \text { p }\end{array}$ & $\underline{\text { http://pubs.usgs.gov/of/2004/1033/ }}$ \\
\hline 2000 & $\begin{array}{l}\text { Neal, C.A., McGimsey, R.G., and Chubarova, Olga, 2004, } 2000 \text { Volcanic } \\
\text { activity in Alaska and Kamchatka: Summary of events and response of the } \\
\text { Alaska Volcano Observatory: U.S. Geological Survey Open-File Report 2004-1034, } 37 \text { p. }\end{array}$ & http://pubs.usgs.gov/of/2004/1034/ \\
\hline 2004 & $\begin{array}{l}\text { Neal, C.A., McGimsey, R.G., Dixon, J.P., and Melnikov, Dmitry, 2005, } 2004 \text { Volcanic } \\
\text { activity in Alaska and Kamchatka: Summary of events and response of the Alaska Volcano } \\
\text { Observatory: U.S. Geological Survey Open-File Report 2005-1308, } 67 \text { p. }\end{array}$ & http://pubs.usgs.gov/of/2005/1308/ \\
\hline 2005 & $\begin{array}{l}\text { McGimsey, R.G., Neal, C.A., Dixon, J.P., Ushakov, Sergey, 2007, } 2005 \text { Volcanic activity in } \\
\text { Alaska, Kamchatka, and the Kurile Islands: Summary of events and response of the Alaska } \\
\text { Volcano Observatory: U.S. Geological Survey Scientific Investigations Report 2007-5269, } \\
94 \text { p. }\end{array}$ & http://pubs.usgs.gov/sir/2007/5269/ \\
\hline 2006 & $\begin{array}{l}\text { Neal, C.A., McGimsey, R.G., Dixon, J.P., Manevich, Alexander, and Rybin, Alexander, } \\
\text { 2009, } 2006 \text { Volcanic activity in Alaska, Kamchatka, and the Kurile Islands: Summary of } \\
\text { events and response of the Alaska Volcano Observatory: U.S. Geological Survey Scientific } \\
\text { Investigations Report 2008-5214, } 102 \text { p. }\end{array}$ & $\underline{\text { http://pubs.usgs.gov/sir/2008/5214/ }}$ \\
\hline
\end{tabular}




\section{Increasing monitoring, increasing information, more to report}

As AVO has expanded instrumental monitoring and made use of the increasing number of high-resolution satellite platforms, the threshold of detection of volcanic unrest in Alaska has lowered considerably. In addition, increasing air and marine-vessel traffic in the Aleutians along with improved Internet and other telecommunications infrastructure in remote Alaska, and the highly visible Web presence of AVO may contribute to the increased number of reports of volcanic activity we receive, evaluate, and log. The focus of this report is on volcanic activity that represents a significant departure from 'background', a somewhat loosely defined state of quiet at a given volcano. For a more quantitative picture of the level of volcanic unrest, readers are referred to the catalog of seismicity at Alaskan volcanoes, also produced on an annual basis (for example, Dixon and others, 2008).

\section{What is an "eruption"?}

The specific use of the term 'eruption' varies from scientist to scientist and there is no universally agreed-upon definition. Here, we adopt usage of the Smithsonian Institution's Global Volcanism Program, which defines eruptions as, “...events that involve explosive ejections of fragmental material, the effusion of liquid lava, or both. This fragmental material may be old as well as new; the explosive interaction of volcanically generated heat and near-surface water can cause dramatic eruptions without any fresh volcanic material reaching the surface." (http://www.volcano.si.edu/faq/index.cfm?faq=02.) The element of this definition we wish to emphasize are the verbs 'eject' and 'effuse' which refer to dynamic surface processes that pose some level of hazard. The presence or absence of often ambiguous 'juvenile material' or fresh magma is not relevant to this use of the term eruption, particularly when communicating a potential hazard that makes no distinction between juvenile and non-juvenile eruption products. This definition would not, however, include passive volcanic degassing or hydrothermalfluid discharge unless accidental solid fragments are entrained.

\section{What is an "historically active volcano"?}

AVO defines an "active" volcano as a volcanic center that has had an eruption (see above) or period of intense seismic or fumarolic activity that is inferred to reflect magma at shallow levels within the volcano. The "historical" period in Alaska is considered post mid-1700s when written records of volcanic activity were first compiled. We include some volcanoes on our list of 'potentially active' volcanoes that do not exactly fit these criteria because geologic evidence suggests that they have been active within the last few thousand years and as such, although not historically active, they retain a potential for hazardous activity that requires careful monitoring. As geologic understanding of Alaska's volcanoes improves through additional fieldwork and modern radiometric-dating techniques, our list of "active" volcanoes will undoubtedly evolve. A case in point from 2006: Fourpeaked Mountain, thought not to have erupted in the Holocene, produced a phreatic eruption in autumn 2006. It now ranks as an historically active volcano, despite not appearing on the list prior to 2006. 


\section{Volcanic Activity in Alaska, Northeast to Southwest along Aleutian Arc}

\author{
Wrangell Volcano \\ CAVW\# 1105-02- \\ $62^{\circ} 00^{\prime} \mathrm{N} 144^{\circ} 00^{\prime} \mathrm{W}$ \\ $4,317 \mathrm{~m}(14,164 \mathrm{ft})$ \\ Copper River Basin \\ TRIGGERED SEISMICITY; STEAMING \\ Fumarolic activity and redistributed ash
}

On January 13, 2007, at 0423 UTC (1923 AKST January 12), a M8.2 earthquake in the Kurile Islands likely triggered seismicity at several Alaska volcanoes including Wrangell, Katmai, and possibly Korovin, as the low frequency, large magnitude wavetrain rolled through these areas (Stephanie Prejean, AVO/USGS, written commun., 2007). There were no reports of anomalous steaming at Wrangell immediately following this event; however, on February 7, a fairly large local earthquake was recorded on the Wrangell network (Katrina Jacobs, AVO/UAFGI, written commun., 2007), that was followed 2 weeks later by reports of steaming from the summit. The report came from staff at Wrangell-St. Elias National Park and Preserve in Copper Center, and was presented during a local newscast (KTUU 5 p.m. report, February 20,2007). This was the first report of Wrangell steaming in several years (see table $4 \mathrm{~b}$ ).

Local residents reported more episodes of steaming in March (figs. 4 and $\underline{5}$ ). On the evening of March 25, a strong sulfur odor was reported by a resident living about 50 air miles north of the summit of Wrangell, who also stated that this occurrence was rare in his 15 years living in the area. Earlier in the day, several multi-station seismic events were recorded on the Wrangell network (Katrina Jacobs, AVO/UAFGI, written commun., 2007). A few months later local residents sent AVO photographs taken on June 20 of steaming from
Wrangell and a deposit of ash extending from the west crater several thousand feet down the southwest flank (fig. 6). This ash was likely redistributed from the summit craters by strong winds. No anomalous seismicity was observed.

Mount Wrangell is a large, glacier-covered shield volcano in Wrangell-St. Elias National Park and Preserve of eastern Alaska (Richter and others, 1995; Miller and others, 1998). The summit caldera is ice-filled with three small, geothermally active craters on the west rim, historically the source of intermittent steam venting. A prominent fumarole field also exists at $12,000 \mathrm{ft}$ on the southwest flank. Steam plumes can be quite vigorous and sometimes reach thousands of feet above terrain, occasionally entraining fine fragmental debris and producing discoloration of the summit area. This is often mistaken for eruptive activity by local residents (table 4b; Neal and McGimsey, 1997; McGimsey and Wallace, 1999; McGimsey and others, 2004; McGimsey and others, 2005b). Four real-time seismic monitoring stations are located on the volcano. Additionally, AVO relies on local observers, pilots, and satellite imagery to monitor activity. Historical activity at Wrangell is enigmatic. A 1902 photograph shows a vigorous steam and ash emission, and there are several anecdotal reports of a small lava flow in 1902. Otherwise, no historical eruptions are known to have occurred at Wrangell volcano (Richter and others, 1995). 


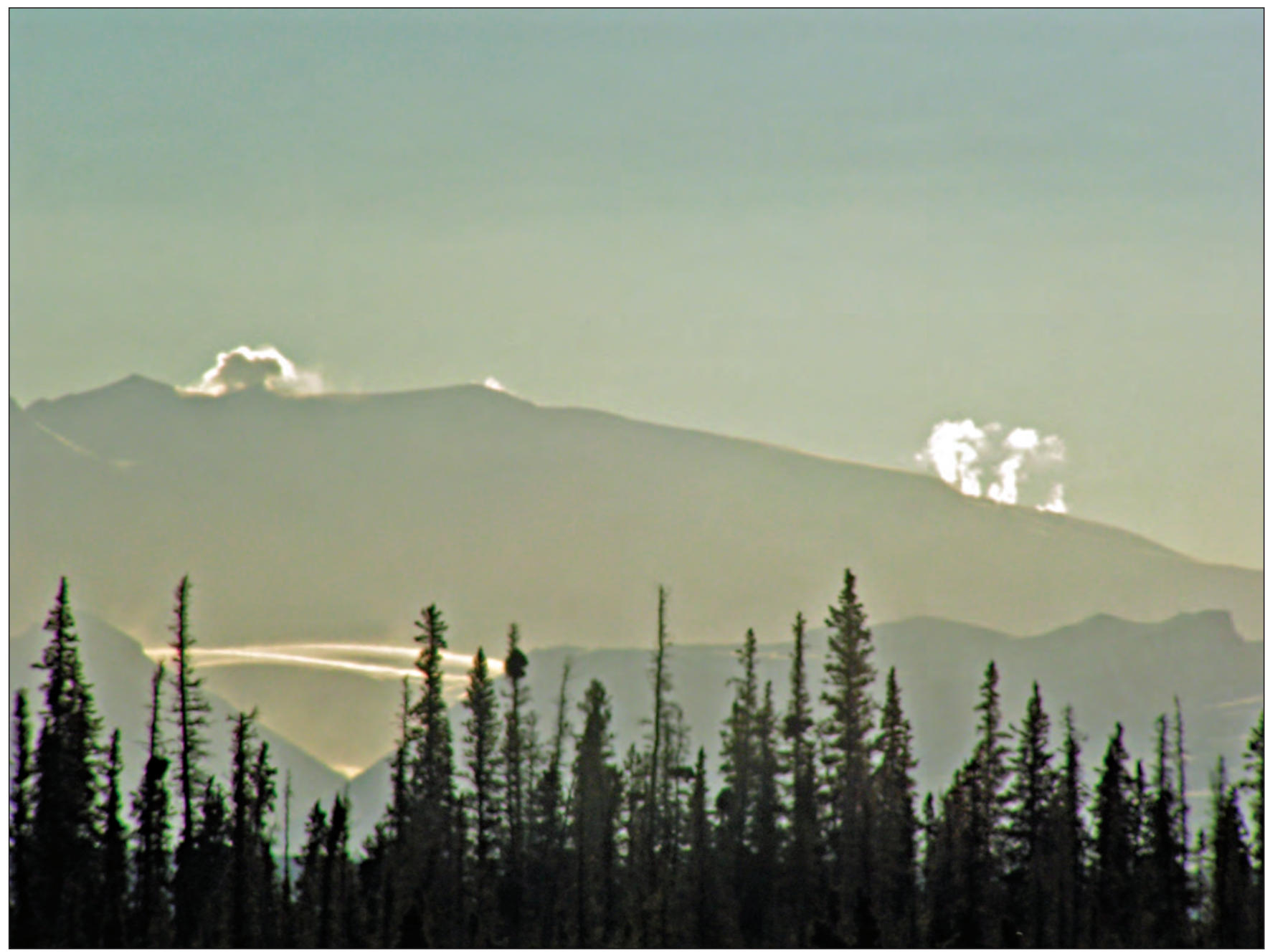

Figure 4. All known active fumaroles on Wrangell were venting steam on this cold (minus $20^{\circ} \mathrm{F}$; minus $29^{\circ} \mathrm{C}$ ) morning at 9 a.m. AKDT on March 20, 2007. View is to the southeast from approximately Mile 18 of the Tok Highway. Photograph by Suzanne McCarthy, Prince William Sound Community College. AVO database image at URL: http://www.avo.alaska.edu/images/image.php?id=13212. 


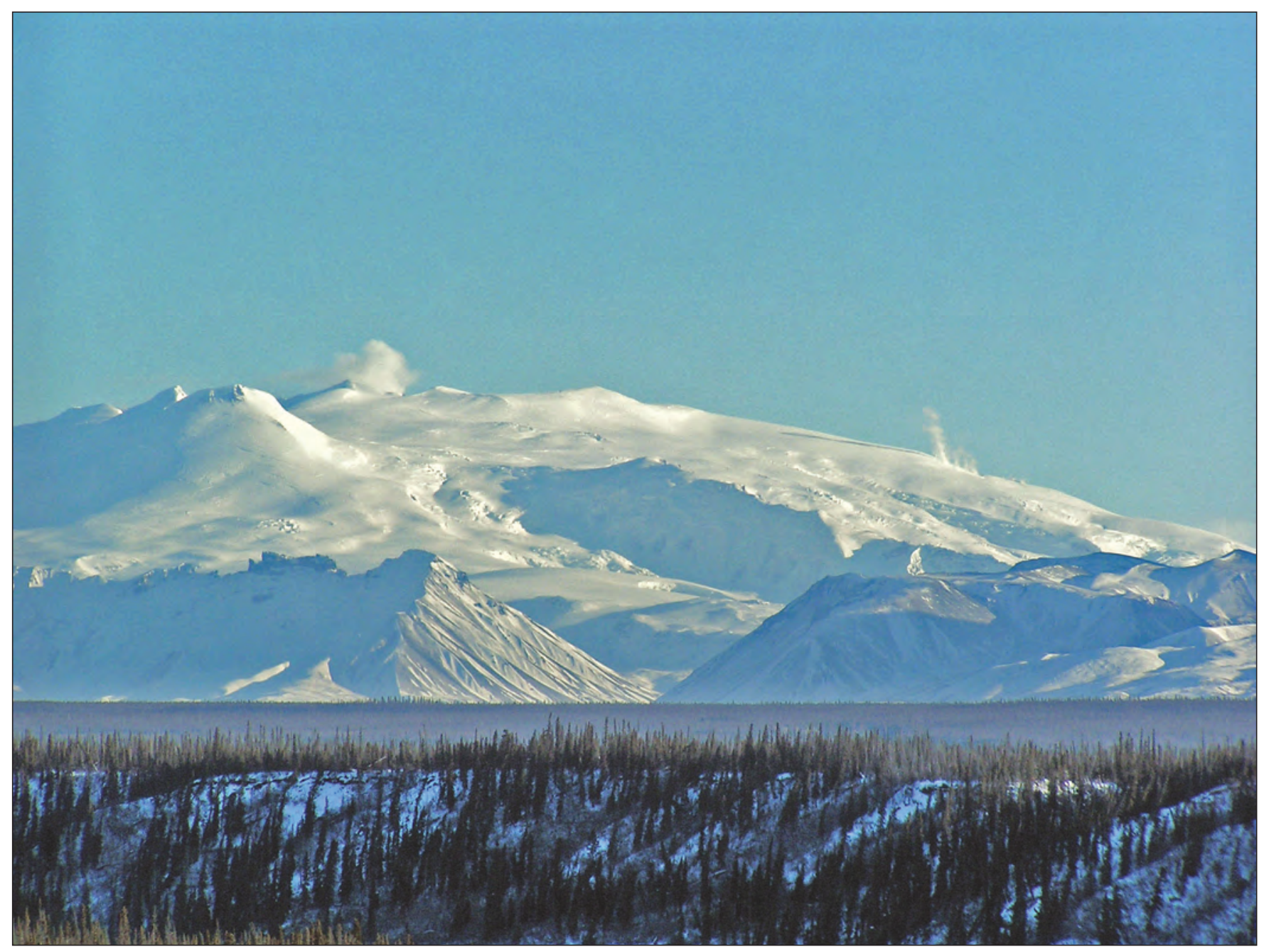

Figure 5. Steam rising from fumaroles in the summit craters of Wrangell as from the prominent fumarole field high on the southwest flank (about 12,000 ft ASL) at 3 p.m. AKDT on March 20, 2007, from approximately Mile 18 of the Tok Highway. Photograph by Suzanne McCarthy, Prince William Sound Community College. AVO database image at URL: http://www.avo.alaska.edu/images/ image.php?id=13214. 


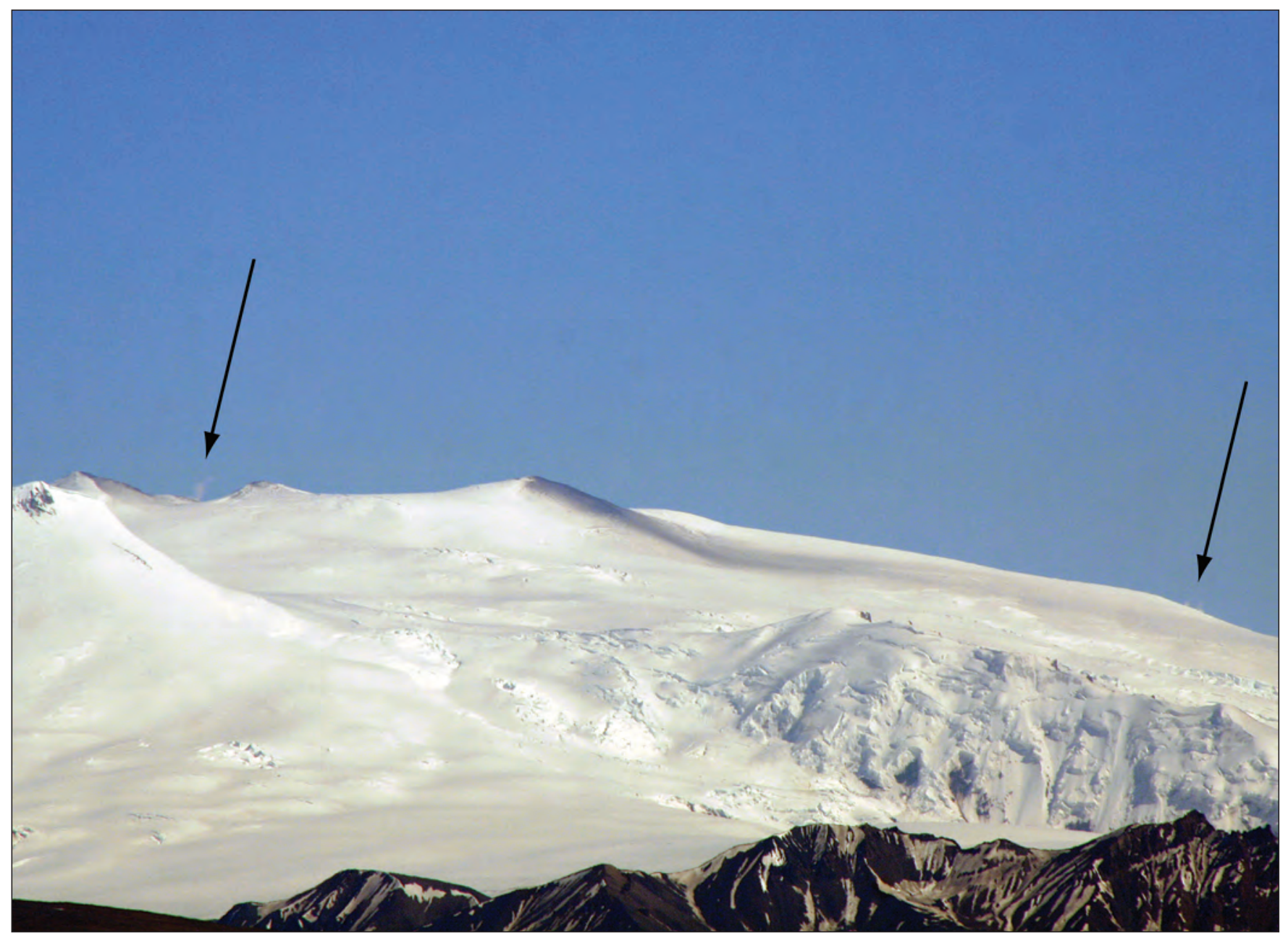

Figure 6. Northwest flank of Wrangell volcano with a dark stripe of probable redistributed ash extending from one of the summit cinder cones (West Crater?). Note the steam plume (left arrow) rising from the skyline saddle left of the ash deposit. Right arrow indicates steam rising from the prominent fumarole located at 12,000 ft on southwest flank. The image was taken at Mile 20 of the Tok Cutoff (Hwy 1), between Gakona and Slana on June 20, 2007. Strong north winds were reported. Photograph by Doyle Traw, private citizen. AVO database image at URL: http://www.avo.alaska.edu/images/image.php?id=13315. 


\begin{tabular}{|l|}
\hline Redoubt Volcano \\
CAVW\# $1103-03-$ \\
$60^{\circ} 29^{\prime} \mathrm{N} 152^{\circ} 45^{\prime} \mathrm{W}$ \\
$3,108 \mathrm{~m}(10,197 \mathrm{ft})$ \\
Cook Inlet \\
SIGNS OF CHANGES IN THERMAL REGIME \\
Reports of steam plumes, and first indications of heat increase to summit dome \\
\hline
\end{tabular}

The 1989-90 eruption of Redoubt Volcano ended with emplacement of a lava dome in late April 1990. Soon thereafter, ice and snow began accumulating in the summit crater (fig. 7). Within 12 years, the dome was largely covered, and ice had re-filled the Drift glacier gorge and reconnected with the piedmont lobe on the north flank (fig. 8). Despite the thick snow cover, two small areas remained bare- - one on the 1990 dome, and the other a few hundred meters west on the dome remnant from the 1965-68 eruption-until sometime in 2005. On May 10, 2005, both of these ice holes are completely covered (fig. 7G). Photographs of the summit crater taken on June 2, 2006, show that the bare ground (ice holes) had returned (fig. $7 \mathrm{H}$ ).

On the morning of January 22, 2007, the National Weather Service Aviation Unit called AVO to convey two pilot reports of "pretty good steaming at Redoubt, cloud drifting north, no sulfur smell." A Web camera to record observations of the Redoubt summit had not been installed yet, but an FAA weather camera located near Beluga showed a puffy cloud cap on the volcano. A check of the seismicity indicated nothing unusual.

Periodic gas measurements and observation flights of the Cook Inlet volcanoes typically include a reconnaisance of Redoubt, and during a flight on Thursday, February 22, 2007, an AVO crew reported no obvious change or disturbance in the 1989-90 dome area of Redoubt, or other parts of the crater or Drift Glacier. The usual two small exposures of rock (ice holes) were present. The co-pilot and one AVO observer reported seeing a possible wisp of steam rising from the ice hole over the 1990 dome. A few days later, on Saturday and Sunday, February 24-25, the AVO Webpage received several reports and photographs from the public of a steam plume rising from Redoubt (fig. 9). In retrospect, these may have been the earliest signs of future unrest (2008) and eruption (2009) at Redoubt.

One of the reports submitted to the AVO Webpage about Redoubt steaming on February 25 mentioned the possibility of "a thin layer of possible ash?? below the steam cloud as it blows south" (fig. 9). The February 22 AVO flight found unfavorable winds for making a gas measurement, so it is unknown whether or not a gas plume was present; however, gas plumes typically contain aerosols and tiny particulates that when backlit can be mistaken for a thin layer of ash, and gas emission typically accompanies initial volcanic unrest. In response to the reports and observations, AVO seismologists examined the recent seismic records, and remote sensors analyzed recent satellite data. Seismicity was normal and nothing unusual was present in satellite images.

Photographs taken by Cascade Volcano Observatory gas specialist, Mike Doukas, during another gas measuring flight on May 18, 2007, clearly show steam or "a small hazy fume cloud" wafting from the bare patch on the 1990 dome, retrospective evidence of heat rising within the dome, and the possible source of gas emission conjectured in February (fig. 10). Gas measurements that day at Redoubt were again unsuccessful, hampered by clouds that prevented low, close passes necessary to measure minor gas emissions, if any were present.

Airborne measurements on September 16, 2007, detected no vapor or gas at Redoubt. Although not noticed at the time, re-analysis of close-in photographs of the summit appear to show steam or vapor rising out of the 1990 dome hole (fig. 7H). AVO received no further reports or observations on Redoubt for the remainder of 2007 and the Aviation Color Code and Volcano Alert Level remained GREEN/NORMAL.

Redoubt Volcano is a glacier-clad, steep-sided stratovolcano, with an ice-filled summit crater widely breached to the north where a deeply incised valley glacier (Drift Glacier) drains the crater to the Drift River Valley. The volcano comprises pyroclastic deposits and lava flows constructed upon Mesozoic granitic rocks of the Alaska-Aleutian Range batholith (Till and others, 1993). The most recent pre-2007 eruptive activity occurred December 14, 1989, through April 1990, and was characterized by 23 episodes of dome construction and destruction-some explosively, and some by gravitational collapse. The resulting pyroclastic flows mixed with ice and snow to produce voluminous lahars that threatened an oil storage and loading facility located along the shore of Cook Inlet, $35 \mathrm{~km}$ (22 mi) downstream along the Drift River (Miller and Chouet, 1994). 


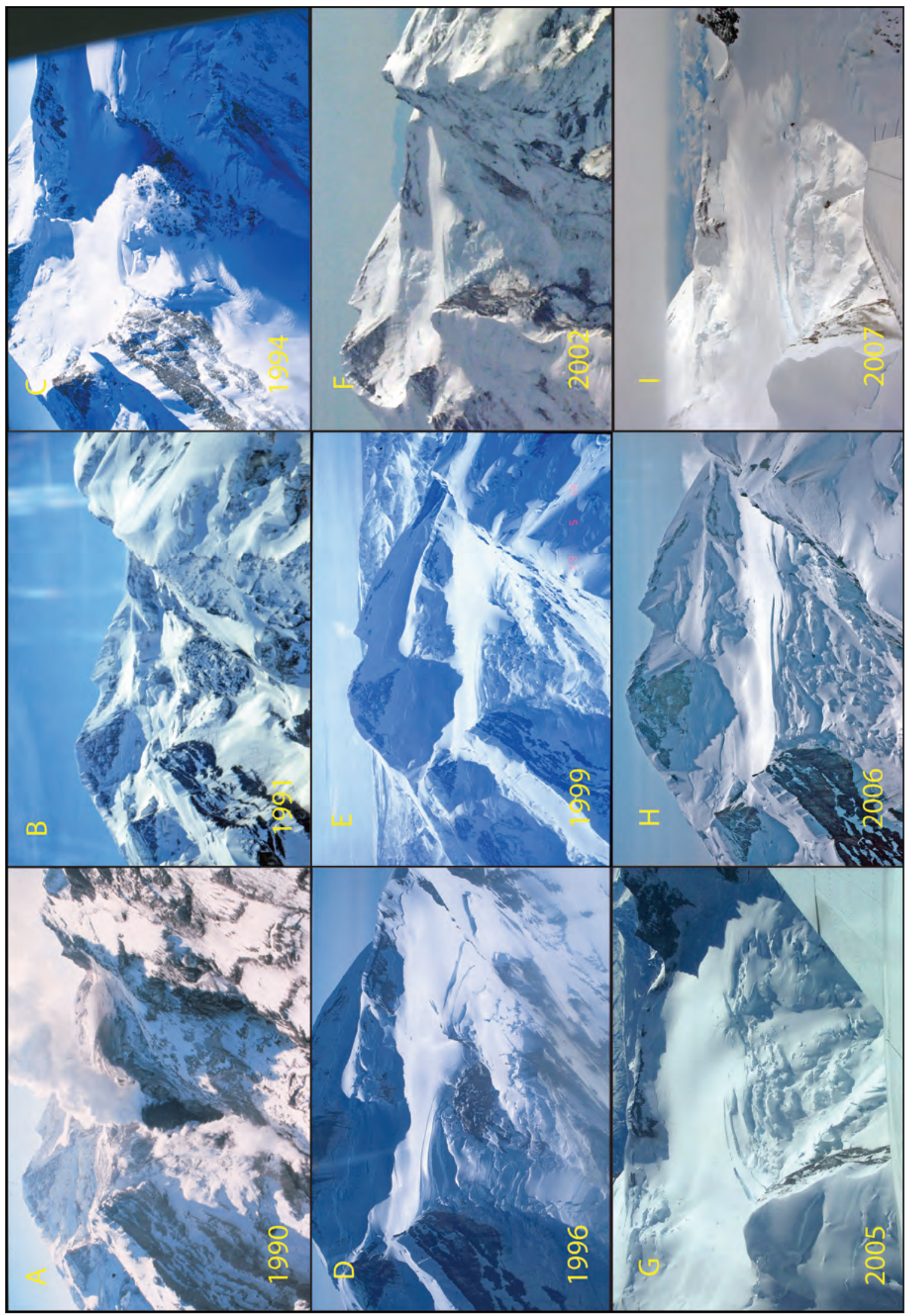

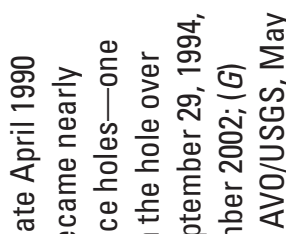
.

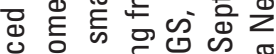
증응 है

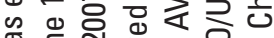

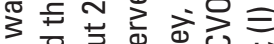

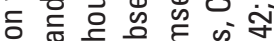

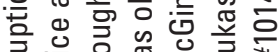

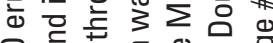

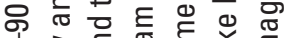
尚

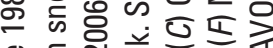

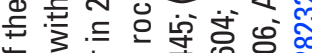

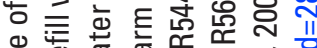
ह 凹 응 웅 స 듀 凹

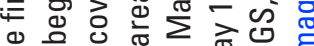

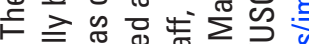

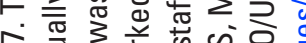

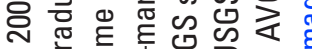
웅응 क 구

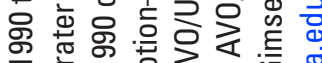
는 윽 穴可

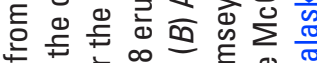

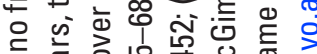
정 ప > के

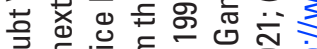
응 记 닌

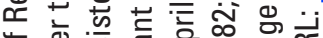

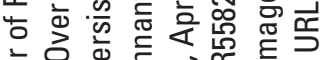

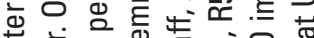

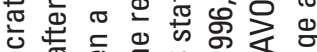

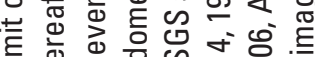

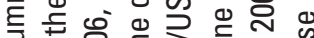
ต

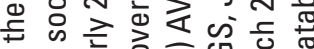

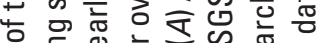

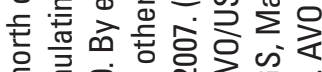
至 언

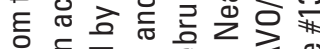
을 등 ऐั む) वे

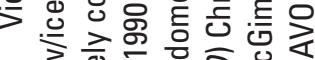

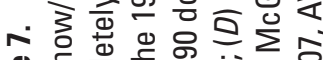

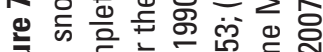

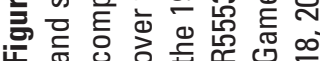




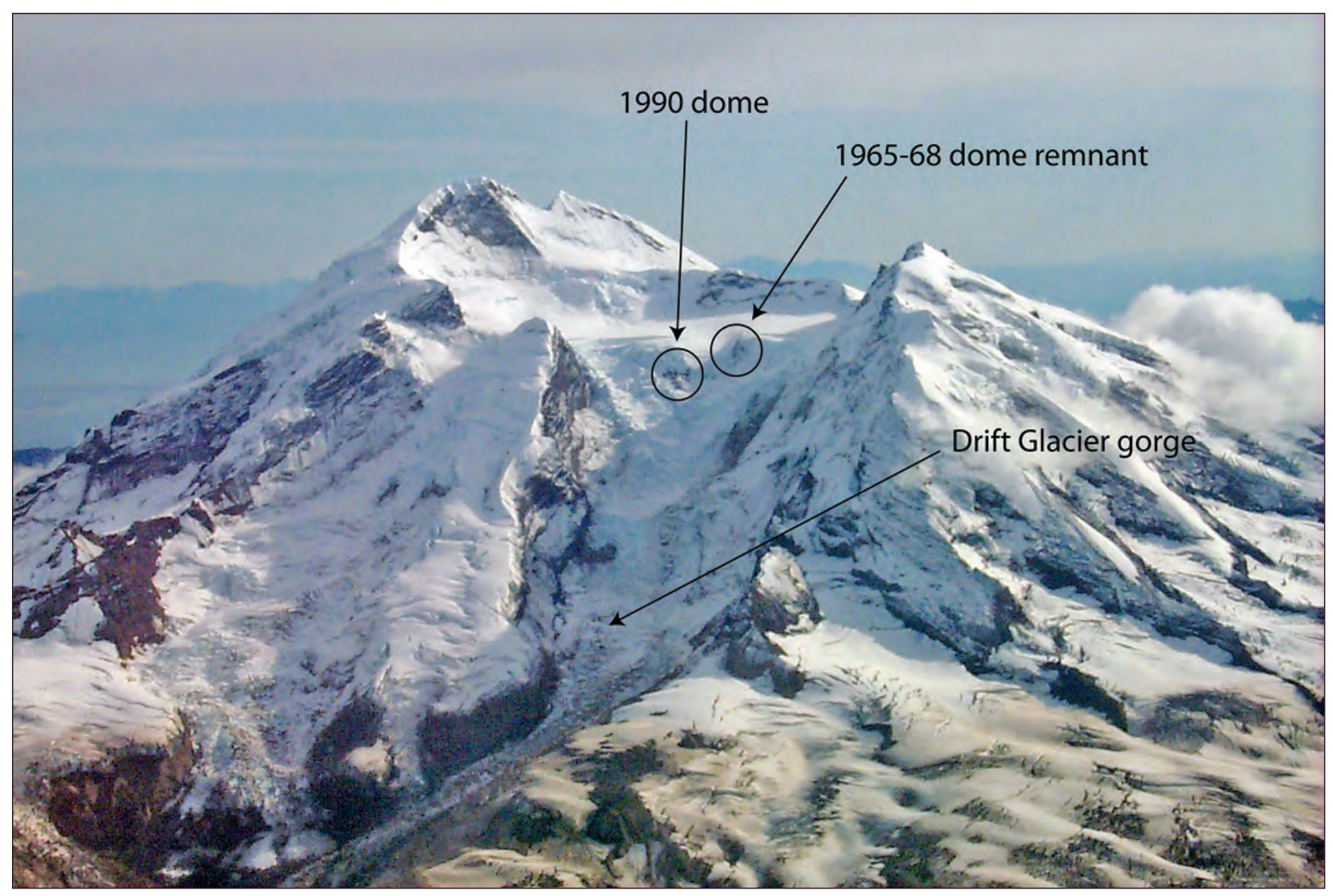

Figure 8. Redoubt Volcano, view of the north flank and summit crater on September 10, 2002. Ice and snow have largely refilled the crater and covered all but a small area of the 1990 lava dome. A dome remnant from the $1965-68$ eruption also remains partially exposed due to warm rock. Continuous ice forming Drift Glacier has re-established in the Drift Glacier gorge. Photograph by Mike Doukas, CVO/USGS. AVO database image at URL: http://www.avo.alaska.edu/images/image.php?id=19801. 


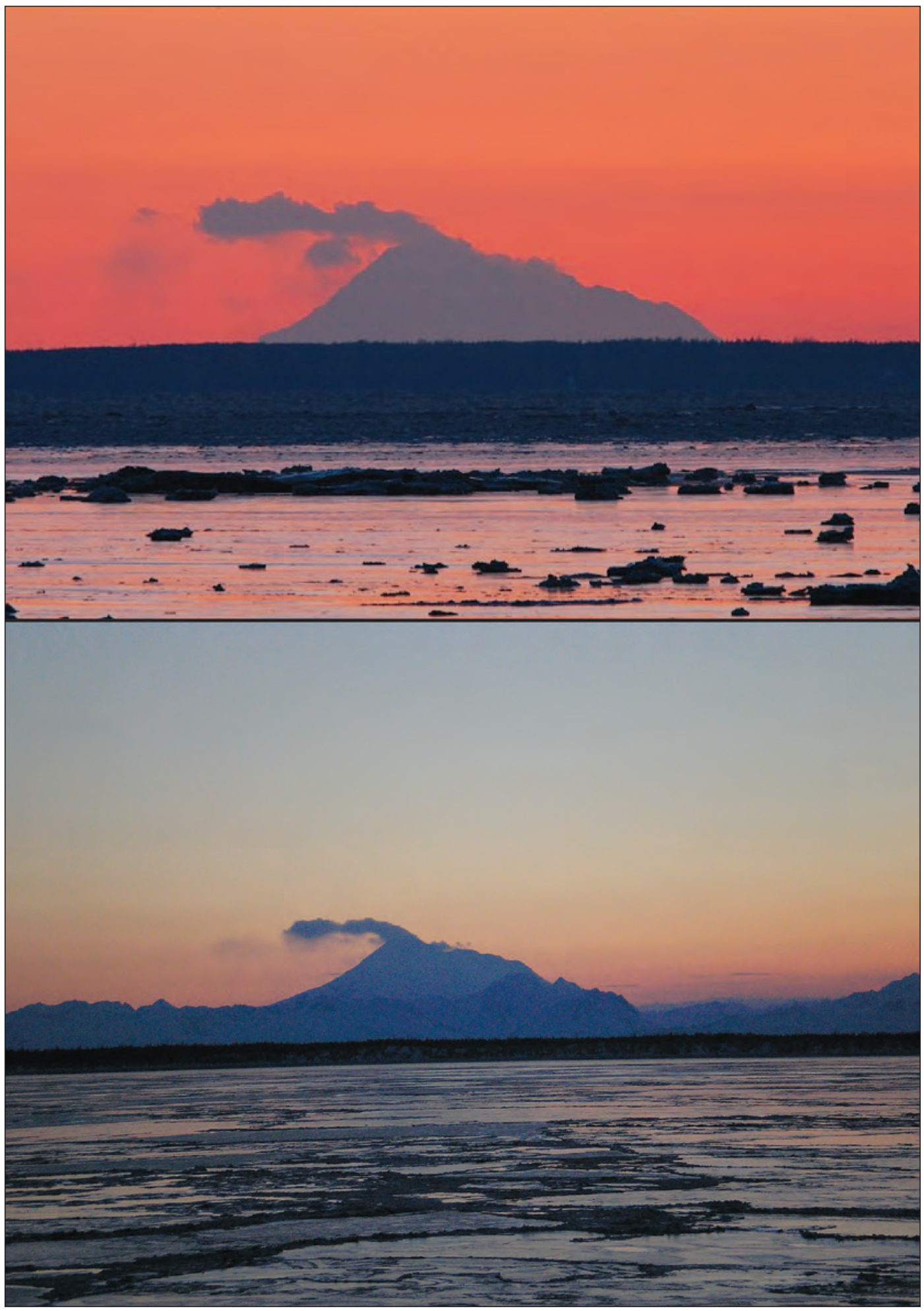

Figure 9. Probable steam plume emanating from Redoubt Volcano on February 25, 2007. Observers wondered if the diffuse tail of the plume contained ash or gas particulates. An AVO fixed-wing flight on February 22, 2007, to make gas measurements and observations found wind conditions unfavorable for a measurement. Top photograph by Neil Moomey from the Seward Highway weigh station near Potter Marsh, 12 mi south of downtown Anchorage, and 110 mi northeast of the volcano. AVO image \#13167; bottom photograph by Christy D. Anderson, from the Unocal Dolly Varden oil platform in Cook Inlet, AVO image \#13168. AVO database image at URL: http://www.avo.alaska.edu/images/image.php?id=28242. 


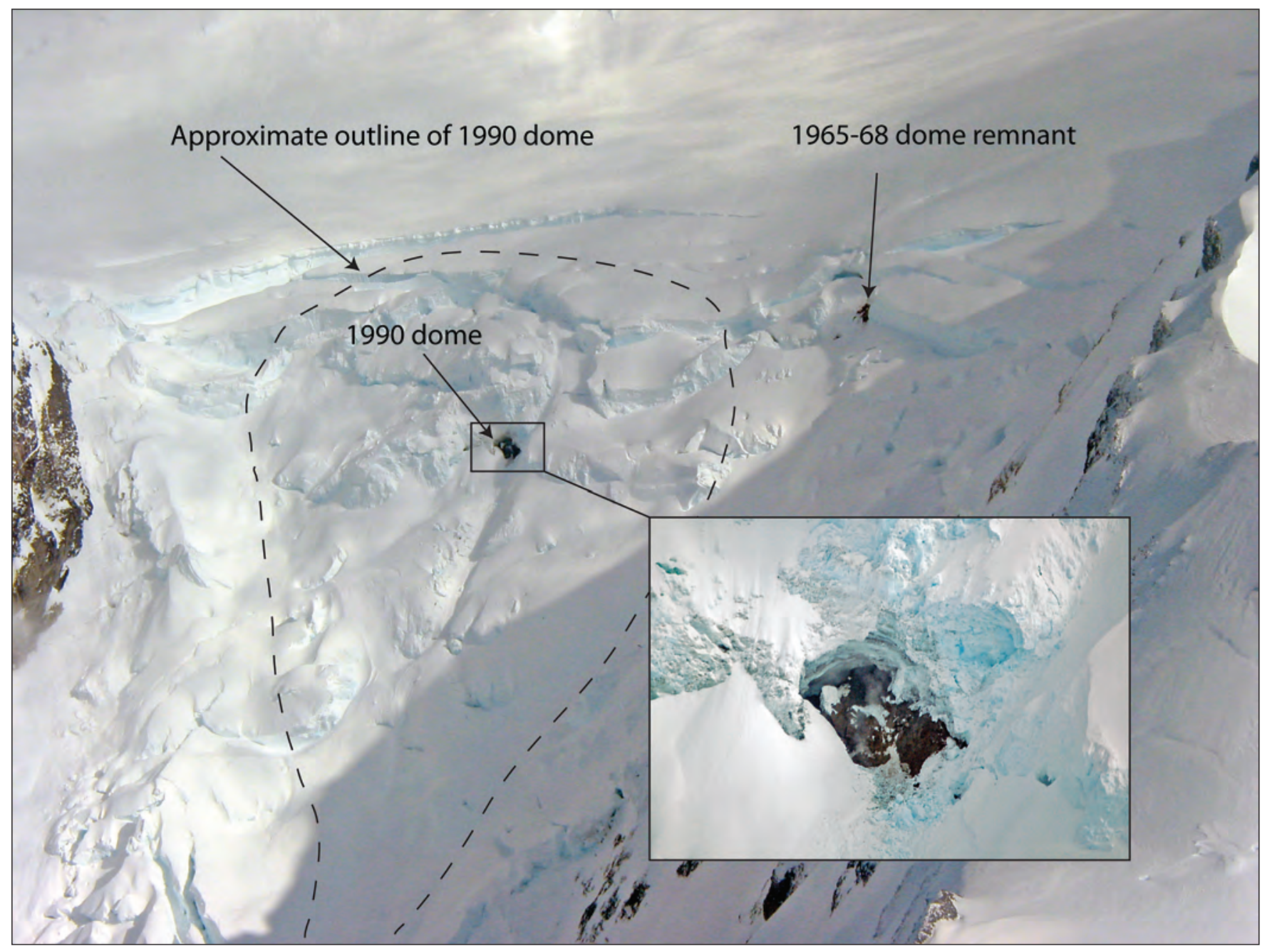

Figure 10. Summit crater of Redoubt Volcano on May 18, 2007. The crater is completely filled with snow and ice except for two areas of bare rock—one over the 1990 dome, and the other over the 1965-68 dome remnant. On this day, steam was observed emanating from the warm rock of the 1990 dome. Photograph by Ken McGee, CVO/USGS. AVO database image at URL: http://www. avo.alaska.edu/images/image.php?id=13272. Inset by Mike Doukas, CVO/USGS. AVO database image at URL: http://www.avo. alaska.edu/images/image . php?id=13268. 


\author{
Augustine Volcano \\ CAVW\# 1103-01- \\ $59^{\circ} 22^{\prime} \mathrm{N} 153^{\circ} 26^{\prime} \mathrm{W}$ \\ $1,260 \mathrm{~m}(4,134 \mathrm{ft})$ \\ Cook Inlet \\ CONTINUED THERMAL MANIFESTATION OF 2005-06 ERUPTION \\ Warm ground, anomalous seismicity, steam plumes
}

The 2005-06 eruption of Augustine Volcano ended with emplacement of a new summit lava dome and two stubby, north-flank lava flows (Neal and others, 2008b; Coombs and others, 2010). Fumarolic activity, residual heating of the summit, and gas emission continued throughout 2007. In addition, intermittent episodes of anomalous seismicity generated extra watch duties and discussions about elevating the Color Code and Alert Level status.

Visual observations made during a routine flight to measure gases (February 22, 2007) included a report that the dome and flows were mostly snow and ice covered with no signs of recent rockfall or debris slides. The tephra-filled moat south of the dome was mostly bare as well as a large portion of the upper west flank (fig. 11). Emission of $\mathrm{SO}_{2}$ was measured to be about 50 tons/d; $\mathrm{CO}_{2}$ was not measured (McGee and others, 2008, 2010).

On March 12, 2007, a short but strong seismic event lasting 45 seconds to 1 minute was recorded on all but one seismic station on the island (broadband AUL, located on the mid-northwest flank). The image interval of the west lagoon Web camera was changed from one image per 120 minutes to one image per 30 minutes in hopes of capturing any anomalous activity. Similar seismic events occurred through the end of March. An AVO seismologist, who visited the summit on March 29, reported no acrid odor or other unusual activity.

Another gas-measuring flight conducted on May 18, 2007, recorded 40 tons/d SO 2 and 90 tons/d $\mathrm{CO}_{2}$. This continued downward trend of gas emissions was consistent with a return to background levels following the 2006 eruption (McGee and others, 2008, 2010).

In mid-July, bursts of tremor were recorded on the local seismic network and AVO began receiving reports of larger-than-normal steam plumes rising from the summit. Intermittent increases in seismicity occurred throughout August accompanied by reports of large steam plumes observed by pilots and residents on the Kenai Peninsula (fig. 12). This pattern of seismicity continued into September and escalated to a vigorous series of events on September 22 prompting AVO to begin systematic seismic watches every 2 hours and to raise the Aviation Color Code to YELLOW and the Volcano Alert Level to ADVISORY. Although the seismicity immediately began to decrease, an unusually strong, broad-frequency event accompanied by harmonic tremor occurred on September 30. The overall pattern of decrease led AVO to reduce the seismic watches back to a 6-hour interval on October 1. A few days later, on October 5, an uptick in seismicity prompted a detailed analysis of satellite imagery to look for evidence of changes in the summit area (for example, emplacement of a spine). The results were negative and seismicity began again to decrease. Status of the volcano was downgraded to GREEN/NORMAL on October 12, 2007. On November 6, the 6-hour seismic watches were canceled. As the system continued to cool and stabilize, intermittent seismic swarms occurred on December 1, 25, and 27.

Augustine Volcano is a 1,260 m (4,134 ft) high conical-shaped island stratovolcano located in southern Cook Inlet, about 290 km (180 mi) southwest of Anchorage, Alaska, and 120 km (75 mi) southwest of Homer, Alaska. AVO maintained a 9-station seismic network on the island in 2007, and The Plate Boundary Observatory (PBO) operated 9 Global Positioning System (GPS) stations. Historically, Augustine is the most active volcano in the Cook Inlet region with significant eruptions in 1812, 1883, 1935, 1963-64, 1976, 1986, and 2005-06 (Miller and others, 1998; Waitt and Begét, 2009). These eruptions primarily were explosive events that produced volcanic ash clouds (to 30,000-40,000 ft above sea level), ash fall, pyroclasic flows, and lava domes or flows. During the 1883 eruption, a large debris avalanche on the north flank of the volcano flowed into Cook Inlet and may have initiated a tsunami observed at Nanwalek about $90 \mathrm{~km}$ (56 mi) to the east (Waitt and Begét, 2009). 


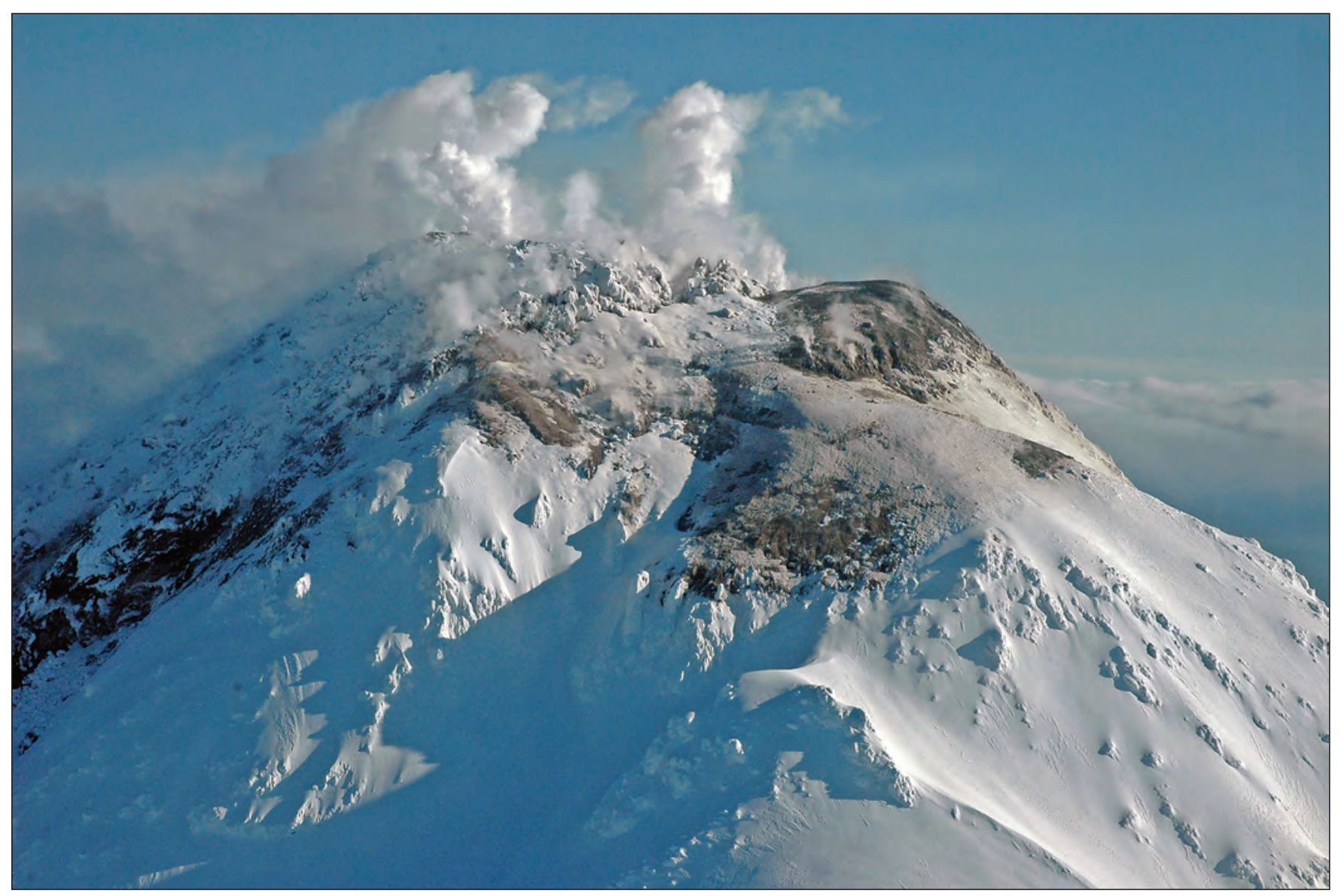

Figure 11. Steam plume and warm ground on the summit of Augustine, February 22, 2007. View is from the west-northwest. Note that most of the summit lava dome is covered in snow and rime ice, while a large portion of the upper west flank is bare and steaming. Photograph by Terry Arion, USGS. AVO database image at URL: http://www.avo.alaska.edu/images/image.php?id=13149. 

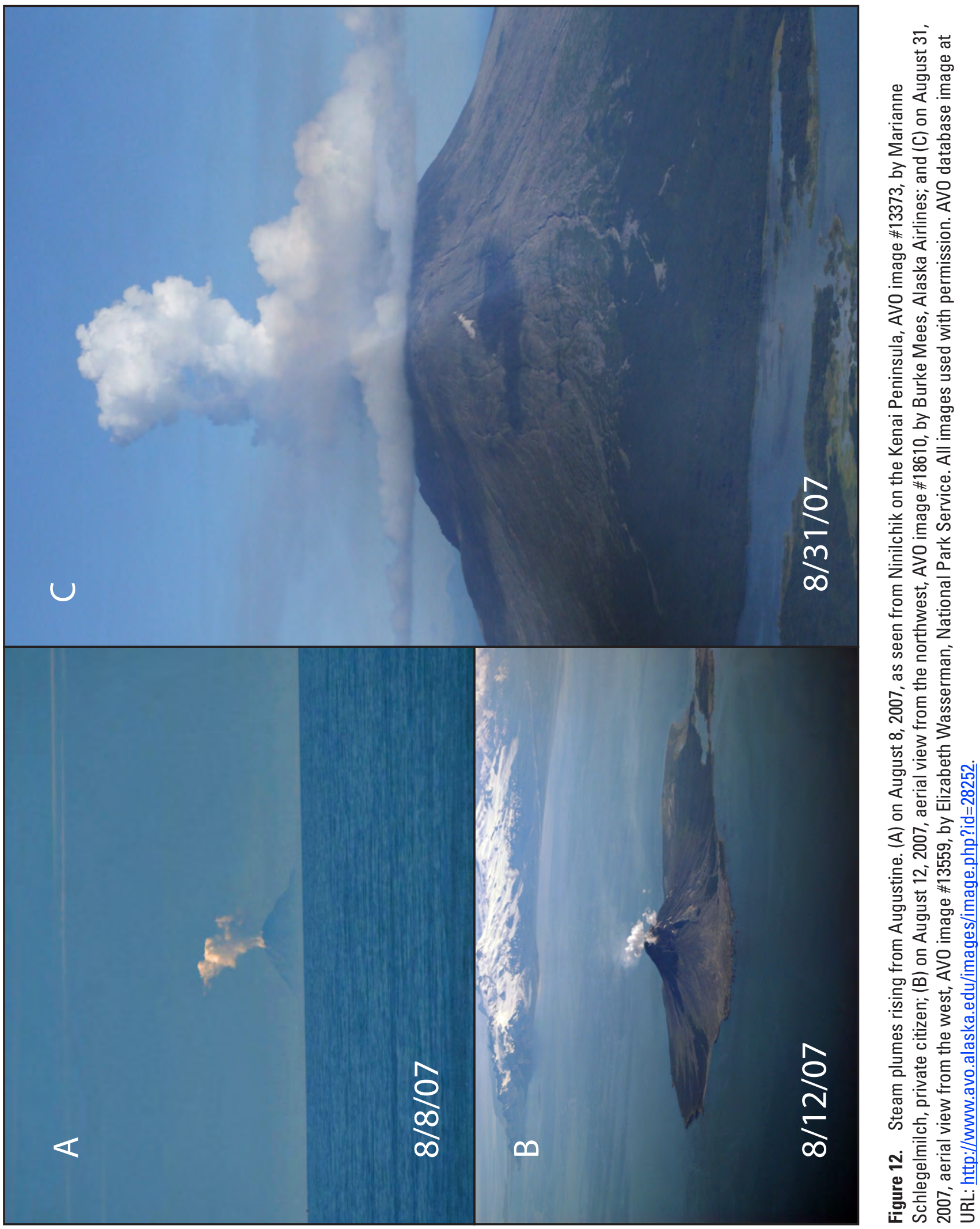


\title{
Fourpeaked Volcano
}

\author{
CAVW\# 1102-26- \\ $58^{\circ} 46^{\prime} \mathrm{N} 153^{\circ} 40^{\prime} \mathrm{W}$ \\ $2,104 \mathrm{~m}(6,903 \mathrm{ft})$ \\ Cook Inlet/Alaska Peninsula \\ GRADUAL DECREASE OF SEISMICITY, STEAM, AND GAS EMISSIONS
}

Following the September 17, 2006, phreatic eruption

Fourpeaked volcano located on the upper Alaska Peninsula had a large, abrupt phreatic eruption and glacial outburst flood in September 2006 (Cervelli and West, 2007; Neal and others, 2008b). Following the initial outburst, steam and volcanic gases continued to vent during the final months of 2006 through the glacier from several point sources immediately north of the summit (ig. 13). A four-station seismic network, pressure sensors, and Web camera to monitor the activity had been hurriedly brought online within a couple weeks of eruption onset. The level of seismicity and continued steam and gas emissions prompted AVO to maintain the volcano at Aviation Color Code YELLOW and Volcano Alert Level ADVISORY into 2007. The post-eruption emissions at Fourpeaked gradually diminished during the first half of 2007 as the seismicity decreased. The status of the volcano was downgraded to GREEN/NORMAL on June 6, 2007.

Steam and gas plumes were frequently visible from Homer, Alaska, on clear-weather days in early 2007 (fig. 14). Seismicity remained elevated, but was sporadic. On February 8 and 9, three small explosive events were recorded by seismic and acoustic instruments, and a plume appeared in satellite images closely following one of these events (fig. 15). Winds that day indicate Fourpeaked was a likely source for the plume. A Web camera image on February 10 shows a robust steam plume and apparent ash on the snow around the uppermost vents (fig. 16), although subsequent analysis of high-resolution satellite data indicated no deposits around the vents on that day. A PIREP of steaming up to $10,000 \mathrm{ft}$. ASL was received on February 15, and on February 18, a small swarm of 13 earthquakes was recorded, including a M1.8 event, $4 \mathrm{~km}$ deep, which was the largest seismic event recorded for the 2006-07 Fourpeaked eruption and unrest. AVO conducted aerial gas measurements on February 22the last measurement had been on November 6, 2006-and recorded continued $\mathrm{SO}_{2}$ output (about 1,000 tons/d) similar to that detected in November, and still considered to be quite elevated, but lower than rates measured in September 2006 ( $>2,000$ tons/d) soon after onset of the unrest (C. Werner, M. Doukas, and K. McGee, CVO/USGS, written commun., 2007). Observers noted that although snow accumulation had begun to mask many of the features, steam and gas emission was still quite voluminous (figs. 17 and 18), and cautioned that much of the steaming is not visible in the Web camera.

Throughout most of March and part of April, the seismic network and acoustic instruments recorded minor events (explosions?) at Fourpeaked, the origins of which were debated by AVO staff in light of decreasing gas emissions. Overall, the seismicity gradually decreased (fig. 19). During the week of March 30, a decrease in steam emission was observed in Web camera images. Seismicity continued to decrease, and an aerial gas measurement on May 18 determined that $\mathrm{SO}_{2}, \mathrm{CO}_{2}$, and $\mathrm{H}_{2} \mathrm{~S}$ emissions were substantially lower from that measured in February. The pits, cracks, and ice holes that opened during the early phase of the eruption and unrest continued to gradually fill with snow, another sign that the activity was waning (fig. 20). Based on the decreasing rate of seismicity and gas emissions, AVO lowered the Aviation Color Code and Volcano Alert Level to GREEN/NORMAL on June 6, 2007. Small steam plumes were occasionally reported throughout the remainder of the year and sometimes visible in the Web camera (fig. 21).

A 4-station seismic network was established at Fourpeaked in the autumn of 2006 to monitor the ongoing eruptive activity; three short-period stations were newly installed around Fourpeaked to compliment a pre-existing short-period seismometer at Cape Douglas. Two pressure sensors and a Web camera rounded out the onsite monitoring equipment. This network operated successfully through the winter, recording more than 380 locatable earthquakes, and on May 3, 2007, AVO issued an Information Release to formally recognize Fourpeaked as 1 of the 31 seismically monitored Alaska volcanoes. 


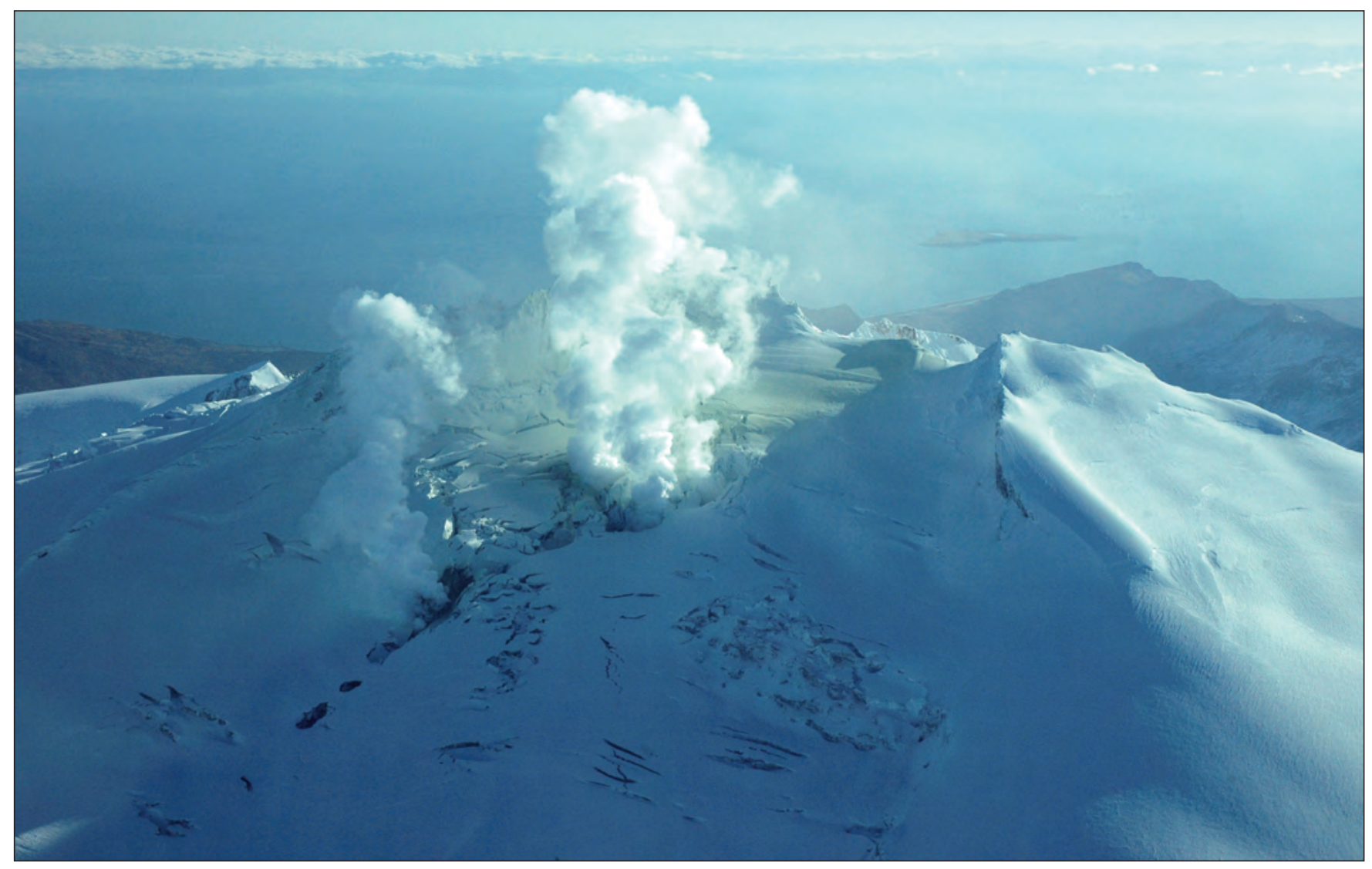

Figure 13. View from the northwest of the line of vents issuing steam and volcanic gases at Fourpeaked volcano, November 4, 2006. Activity began with an abrupt, large phreatic eruption on September 17, 2006. Steam and gas continued to vent over the next several months, continuing into 2007. Photograph by Game McGimsey, AVO/USGS. AVO database image at URL: http://www.avo. alaska.edu/images/image.php?id=12397.

Fourpeaked volcano lies within the northeastern corner of Katmai National Park and Preserve on the Alaska Peninsula, $12 \mathrm{~km}$ (7.5 mi) southwest of Mount Douglas (fig. 1). The edifice is defined by "four peaks", which are isolated, eroded exposures of lava flows along ridge crests and cliff faces that radiate out from the ice-covered summit (J. Fierstein, USGS, written commun., 2007). The source areas (pits or vents) for the recent activity extend linearly from high in the summit crater (or cirque), northward for about 1,250 m (4,100 ft). Until late 2006, no historical activity was recorded for this volcano. Age of the last significant eruption is not known but considered to be pre-Holocene $(>10,000)$. On September 17, 2006, two large steam plumes were observed rising from Fourpeaked to an altitude of about $6,000 \mathrm{~m}$ above sea level $(20,000 \mathrm{ft})$. An ensuing glacial outburst flood scoured a steep-walled canyon more than $100 \mathrm{~m}$ (330 ft) deep and moved mixture of water and fine-grained to boulder-sized ice and debris at least $6 \mathrm{~km}(4 \mathrm{mi})$ downslope (Neal and others, 2008b). Subsequent gas measurements showed a significant amount of $\mathrm{SO}_{2}$ issuing from the volcano. Following the eruption, a report surfaced of a similar steam and gas plume observed by a mariner during the summer of 1965 . 


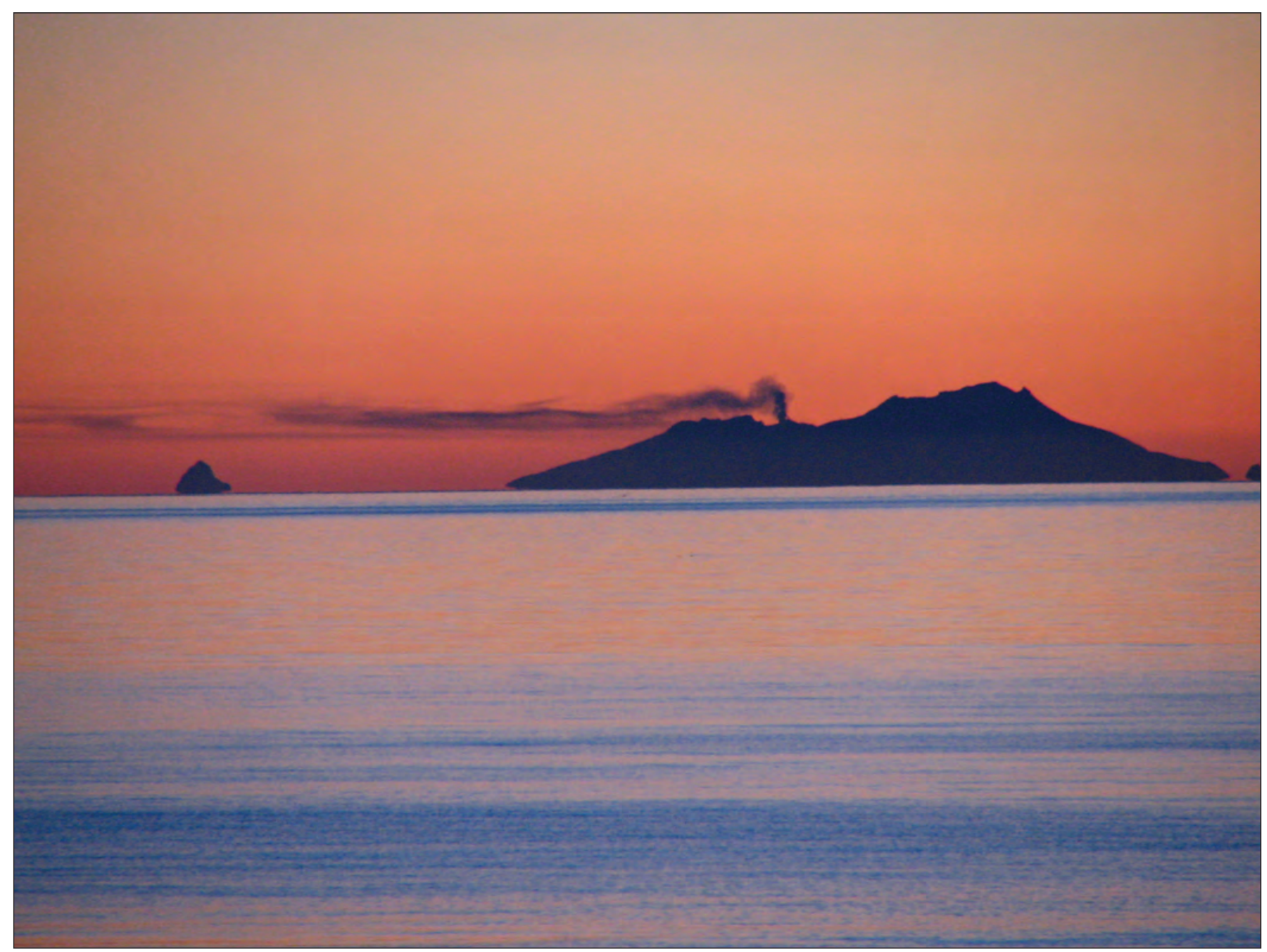

Figure 14. Steam and gas plume drifting southward from Fourpeaked volcano, February 2, 2007. View is from Homer, Alaska. Photograph by Bob Shavelson, private citizen. AVO database image at URL: http://www.avo.alaska.edu/images/image. php?id=13136. 

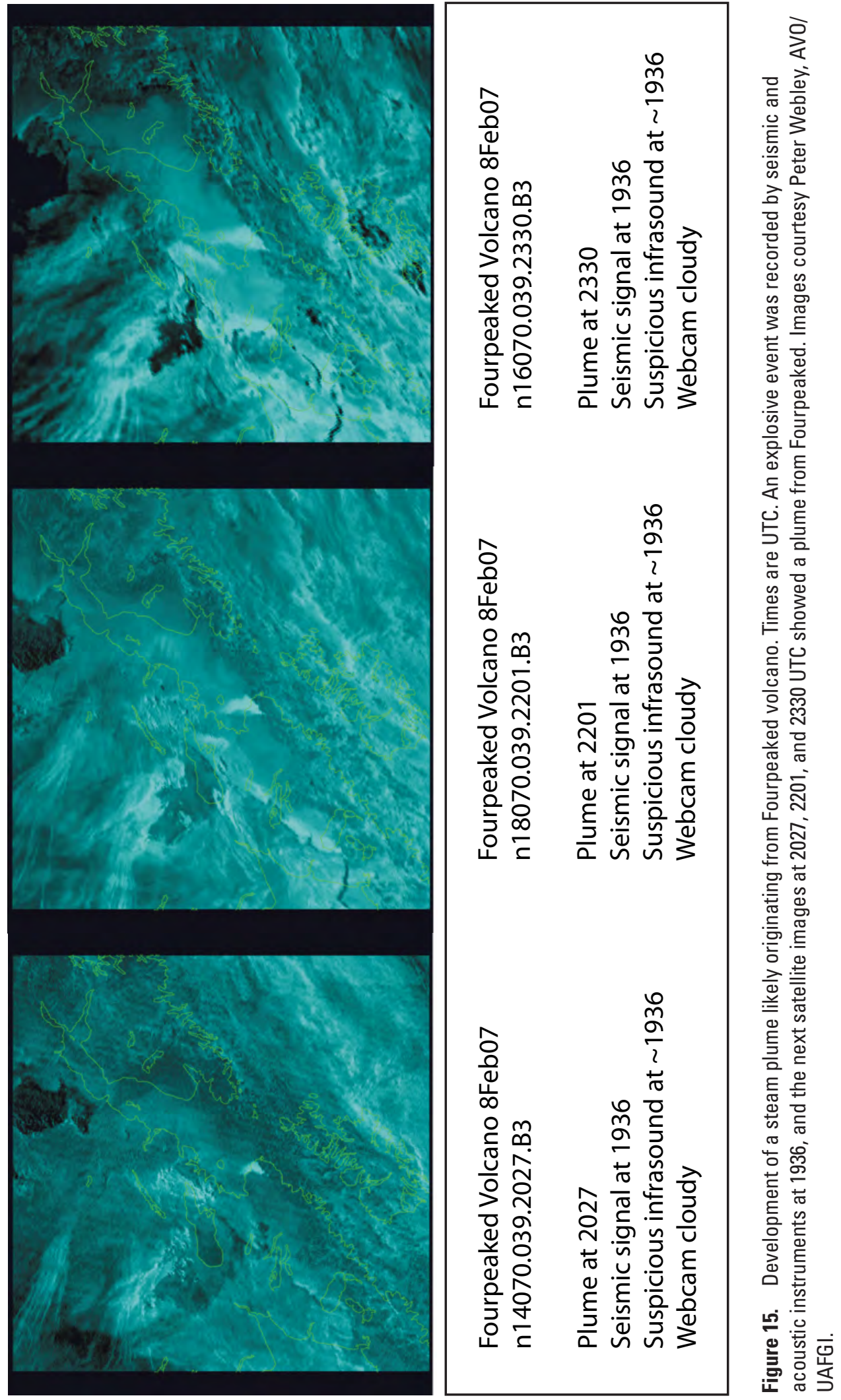


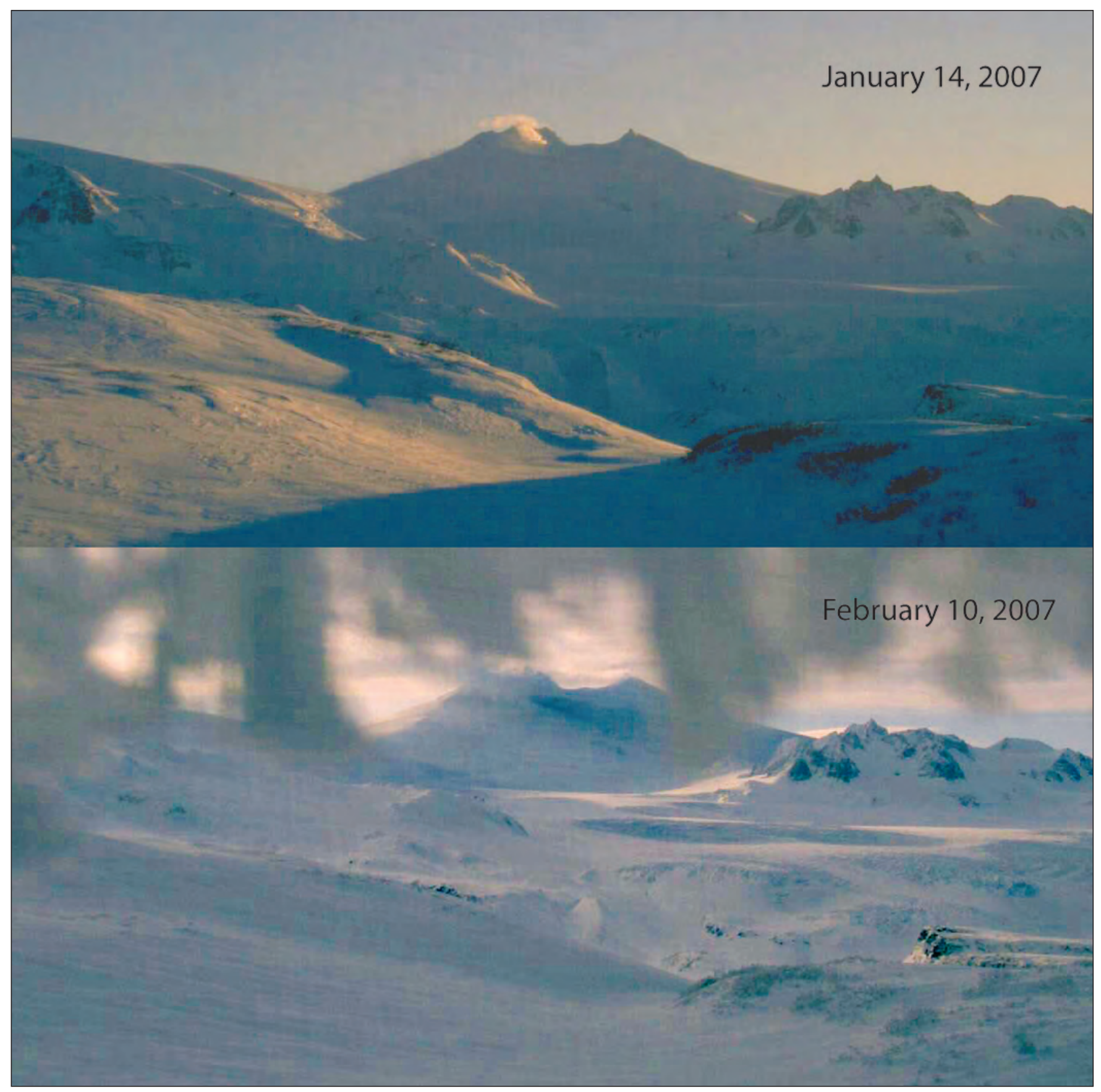

Figure 16. Web camera images from January 14 (upper) and February 10, 2007 (lower-ice crystals obscure the upper portion of image). The dark coloration of the summit crater area in the February image was considered to possibly be newly deposited ash. AVO database image at URL: http://www.avo.alaska.edu/images/image. php?id=28262. 


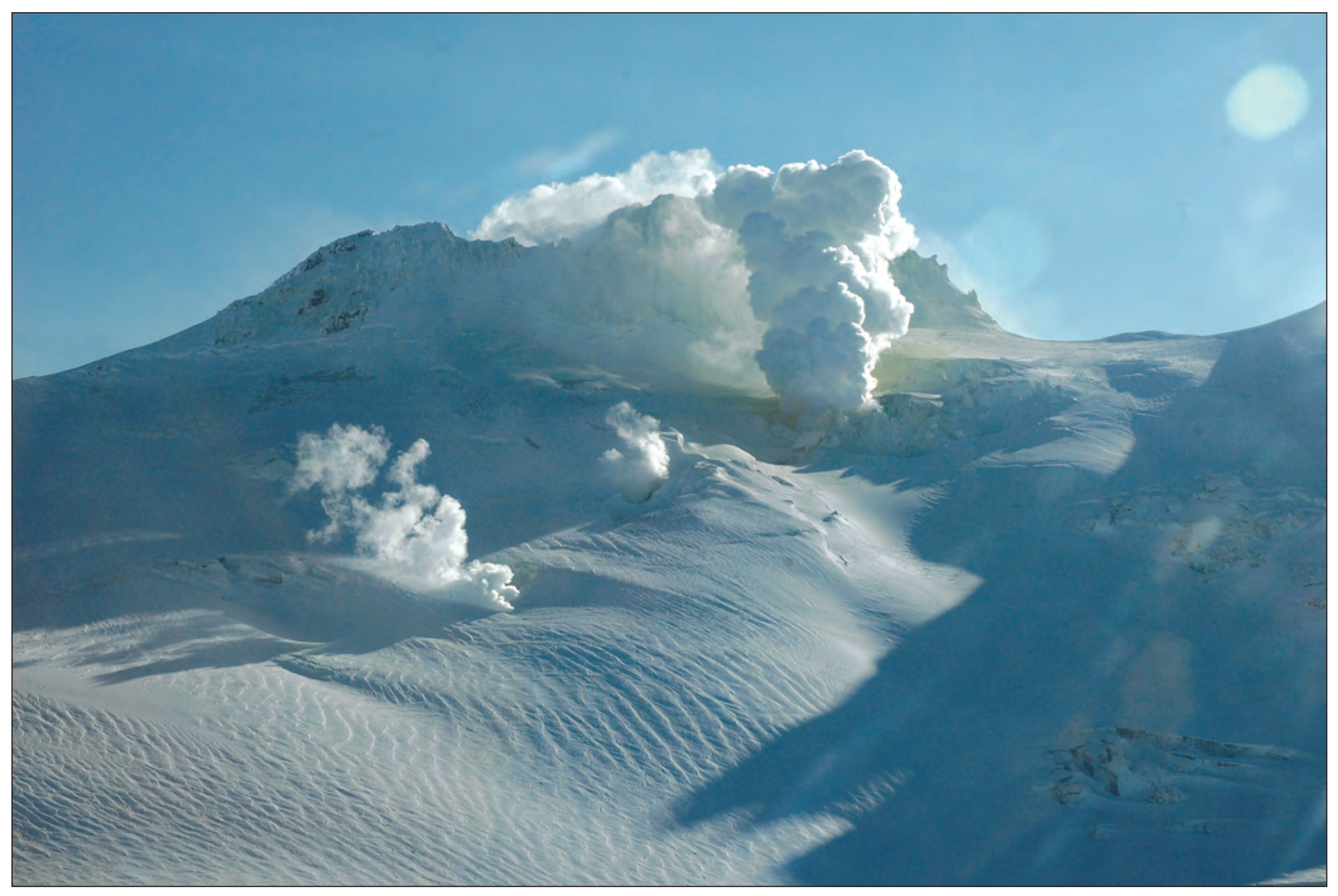

Figure 17. Vigorous emission of steam and gas from vents located near the summit of Fourpeaked volcano, February 22, 2007. Aerial gas measurements conducted on this day by AVO recorded continuing high levels of $\mathrm{SO}_{2}$. Photograph by Terry Arion, USGS. AVO database image at URL: http://www.avo.alaska.edu/images/image.php?id=13148. 


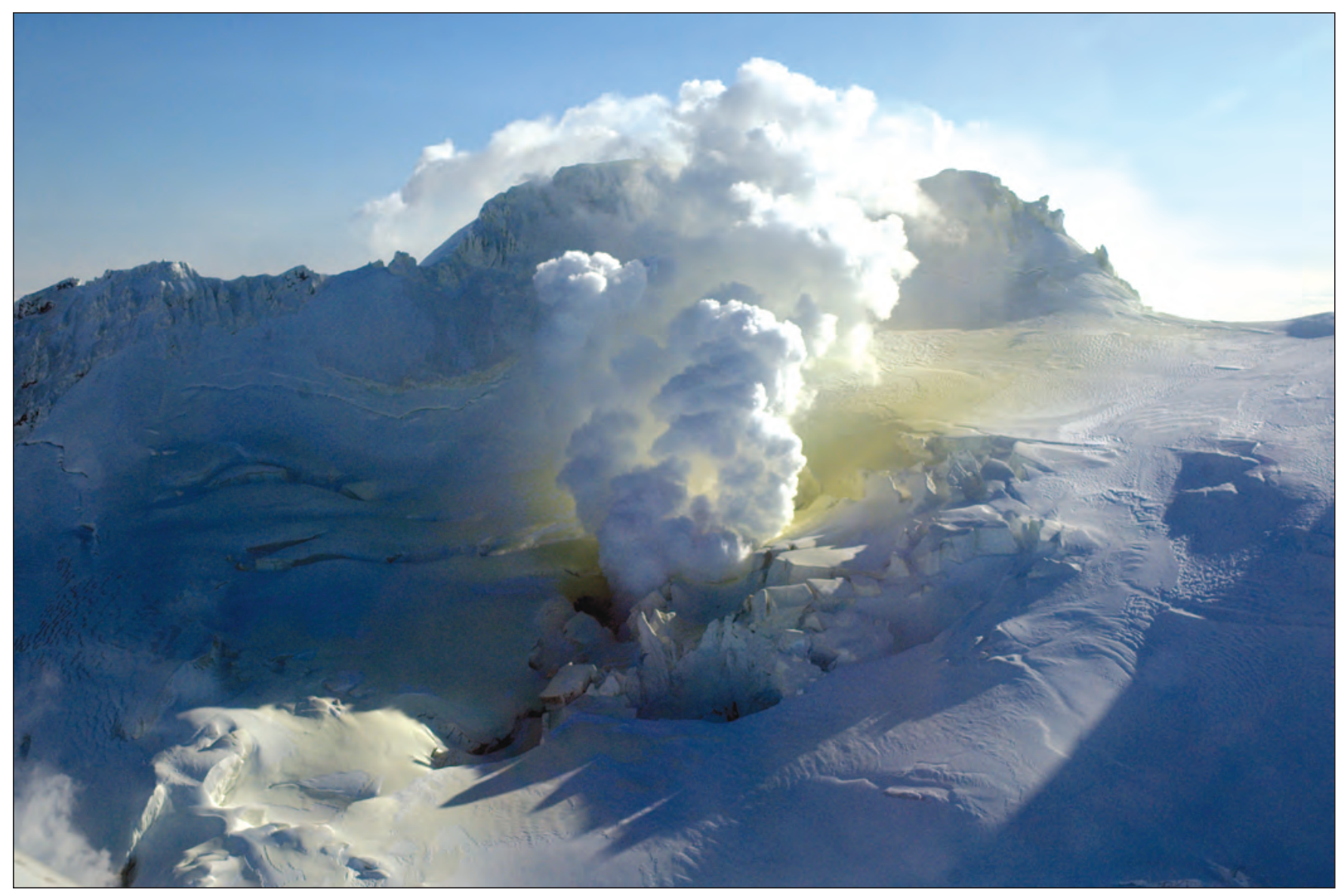

Figure 18. Uppermost and largest of the active vents on Fourpeaked volcano during an AVO aerial gas-measurement flight, February 22, 2007. Sulfur deposition is visible on the snow under the steam/gas plume. Photograph by Cyrus Read, AVO/USGS. AVO database image at URL: http://www.avo.alaska.edu/images/image.php?id=13141. 


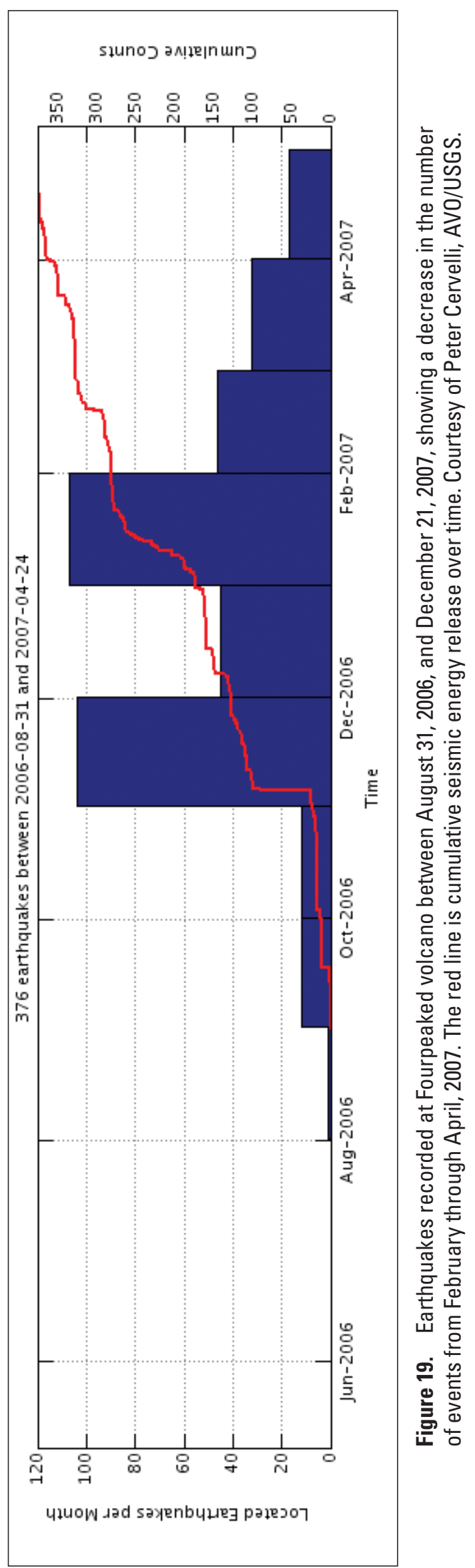




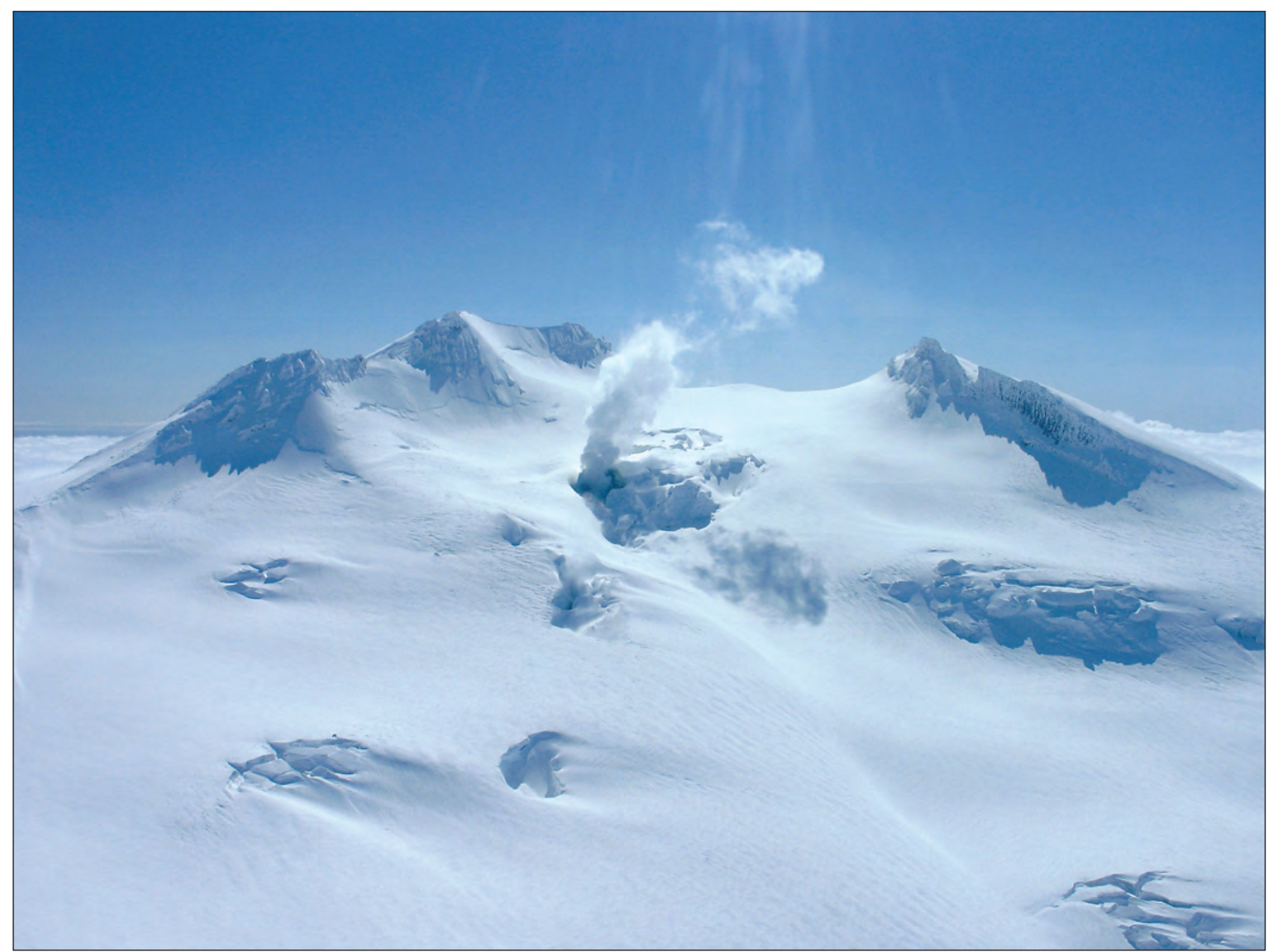

Figure 20. Steam and possibly some gas continues to rise from vents near the summit of Fourpeaked volcano, May 18, 2007. Photograph by Christina Neal, AVO/USGS. AVO database image at URL: http://www.avo.alaska.edu/images/image.php?id=13279. 


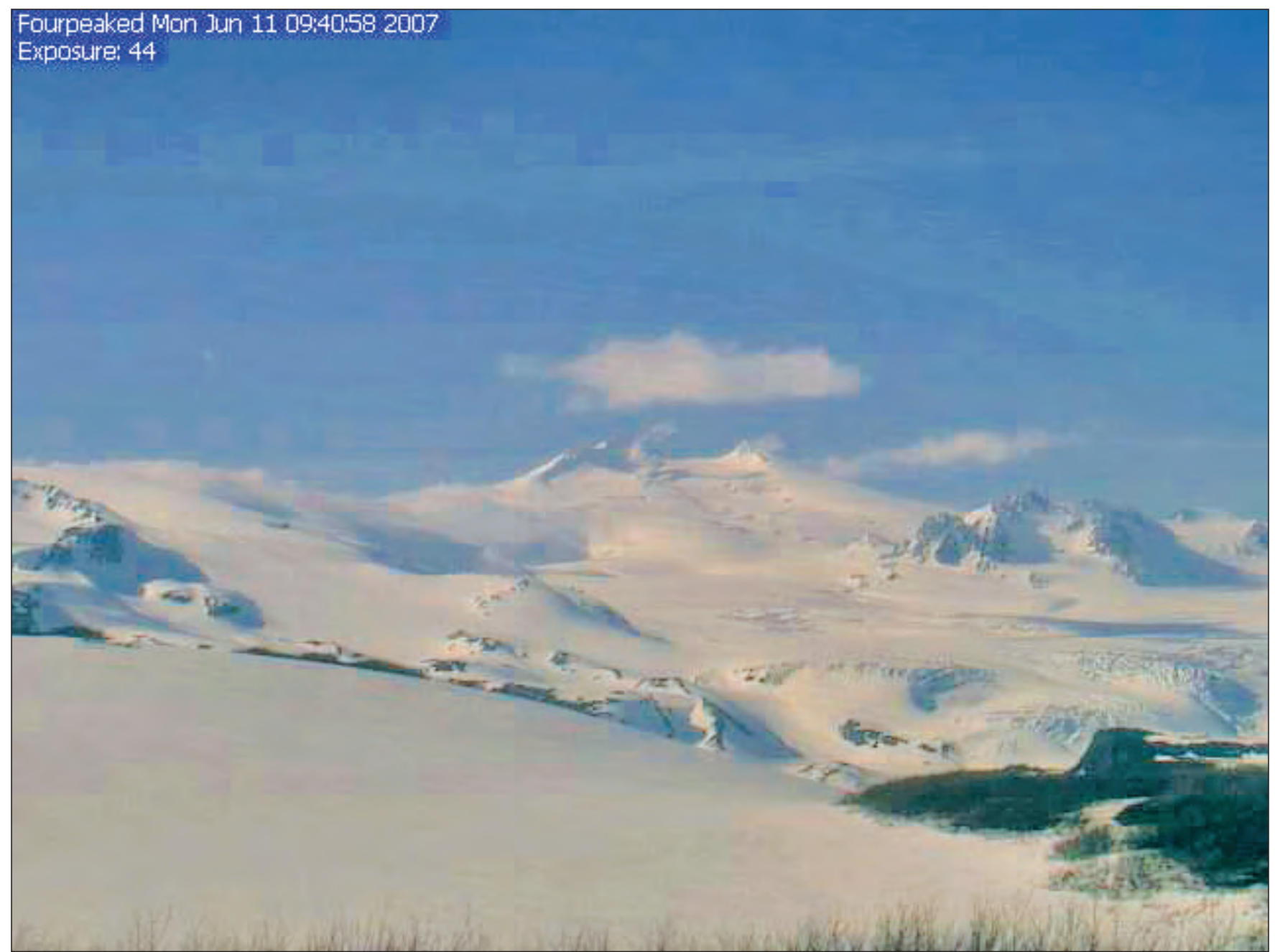

Figure 21. Web camera image of Fourpeaked volcano on June 11, 2007, showing continued emission of a small steam plume. AV0 database image at URL: http://www.avo.alaska.edu/images/image.php?id=28272. 


\section{Mount Veniaminof Volcano}

CAVW\# 1102-07-

$56^{\circ} 12^{\prime} \mathrm{N} 159^{\circ} 24^{\prime} \mathrm{W}$

$2,507 \mathrm{~m}(8,225 \mathrm{ft})$

Alaska Peninsula

DECREASE OF MINOR PHREATIC ERUPTIONS, LOWERING OF STATUS

Mostly diffuse steam rising from the intracaldera cone

The long-term, low-level eruptive activity at Veniaminof volcano that had diminished in frequency and intensity in late 2005 (McGimsey and others, 2007) resumed in 2006, and then carried forth into the early months of 2007 before subsiding again. The volcano entered 2007 in Aviation Color Code/ Volcano Alert Level YELLOW/ADVISORY following minor eruptions of ash throughout much of 2006 (Neal and others, 2008b). By January 2007, the intracaldera cinder and spatter cone was producing only minor, diffuse steam plumes that rose at most a few hundred meters above the vent. Discussions began at AVO weekly staff meetings about lowering the status of Veniaminof. The transition from emitting ash-andsteam clouds to only steam prompted AVO seismologists to undertake a systematic analysis of seismic data to determine if activity had decreased.

Following several weeks of cloudy weather, clear Web camera views on the morning of February 16, 2007, revealed vigorous steaming from the intracaldera cone (fig. 22). Clouds and a short camera outage prevented observations for several days, and then on the morning of February 20, a clear view showed little to no steaming from the cone. Minor steaming was visible through February 24 when weather permitted, and by February 25, no signs of steam emissions were apparent in Web camera images. Over the next couple of months, intermittent clear views of the volcano in either Web camera images or in satellite images showed that occasionally minor steam plumes were issuing from the intracaldera cone. Seismicity had decreased to background levels several months prior, and the last ash-laden plume visible in Web camera images was on November 2, 2006. The last thermal anomaly visible in satellite images was on July 5, 2006. Ground observers and pilots reported no unusual activity in recent months, and therefore on April 26, 2007, AVO lowered the Aviation Color Code/Volcano Alert Level to GREEN/ NORMAL. Based on historic patterns of eruptive behavior, AVO anticipated continued steaming from the cone. Indeed, Veniaminof continued to steam intermittently throughout 2007 (fig. 24).

Veniaminof, an ice-clad, about 350-km³ (about 84-mi ${ }^{3}$ ) andesite and dacite stratovolcano, is one of the largest and most active volcanoes of the Aleutian arc (Miller and others, 1998; Bacon and others, 2007). Located 775 km (482 mi) southwest of Anchorage and $35 \mathrm{~km}$ (22 mi) north of Perryville (fig. 1), the summit hosts an ice-filled, 10-km diameter (6.2 mi) caldera. Two Holocene caldera-forming eruptions are recorded in extensive pyroclastic-flow deposits around the volcano (Miller and Smith, 1987). Low-level, largely phreatic ash explosions from the approximately 350-m-high (about 1,150 ft) intracaldera cone have occurred intermittently since 2002, while the last significant magmatic eruption occurred in 1993-95 (Neal and others, 1995; McGimsey and Neal, 1996; Neal and others, 1996). This eruption was characterized by intermittent, low-level emissions of steam and ash, and production of a small lava flow that melted a pit in the caldera-ice field. During the more significant historical eruptions, ash plumes reached about 7,800 m (about 26,000 ft) ASL and produced ash fallout within about $40 \mathrm{~km}$ (about $25 \mathrm{mi}$ ) of the volcano. In 2007, the volcano was monitored by a network of eight seismometers (fig. 23). 


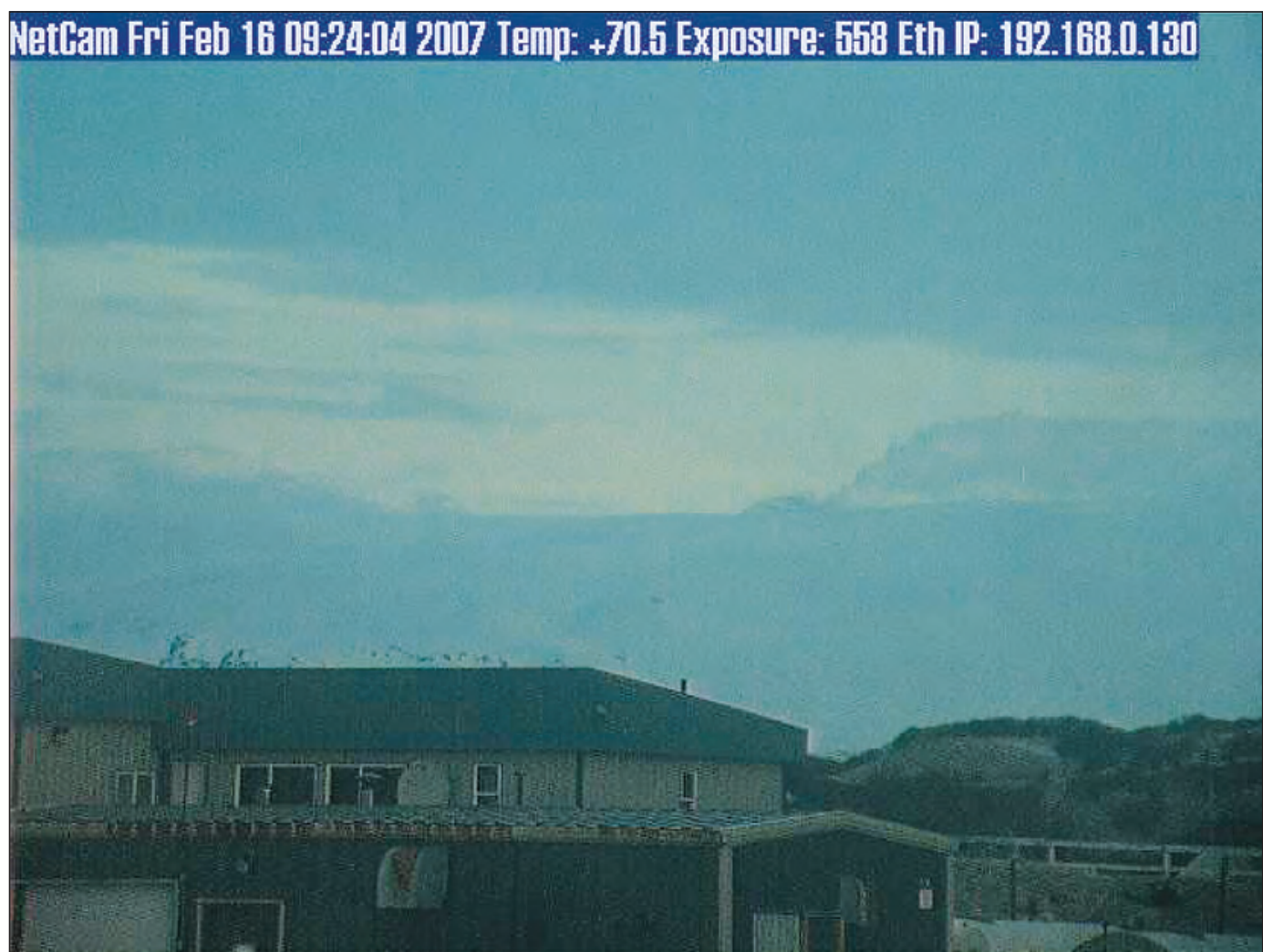

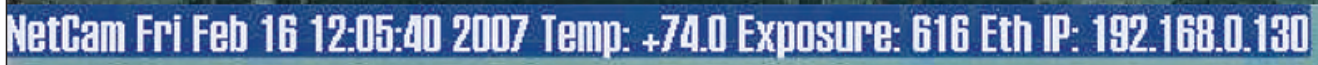

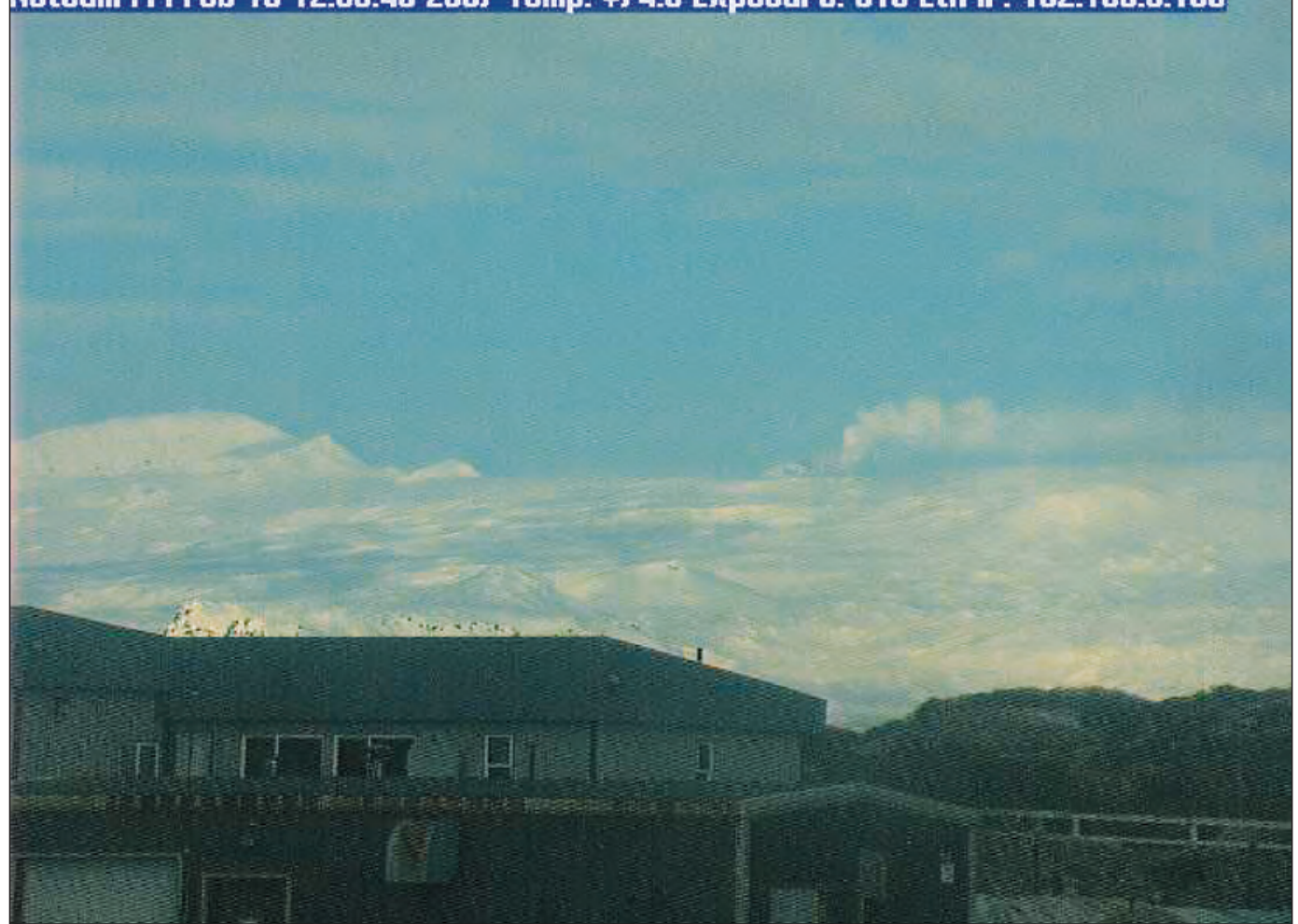

Figure 22. Web camera images of vigorous emission of steam from the intracaldera cone in the Veniaminof caldera. Web camera is situated in Perryville, $35 \mathrm{~km}$ (22 mi) south of the central cone. These Web camera images were taken on February 16, 2007, the upper at 09:24:04 a.m. during first light, the lower at 12:05:40 p.m. midday. The steam plume was visible throughout the day on February 16; clouds obscured the view on February 17-19. The camera went out-of-service at 13:40 p.m. on February 19 through 09:04 a.m. on February 20. When it came back online, the first image on is a clear view with little to no steam rising from the cone. All times are AKST. AVO database image at URL: http://www.avo.alaska.edu/images/image.php?id=28282. 


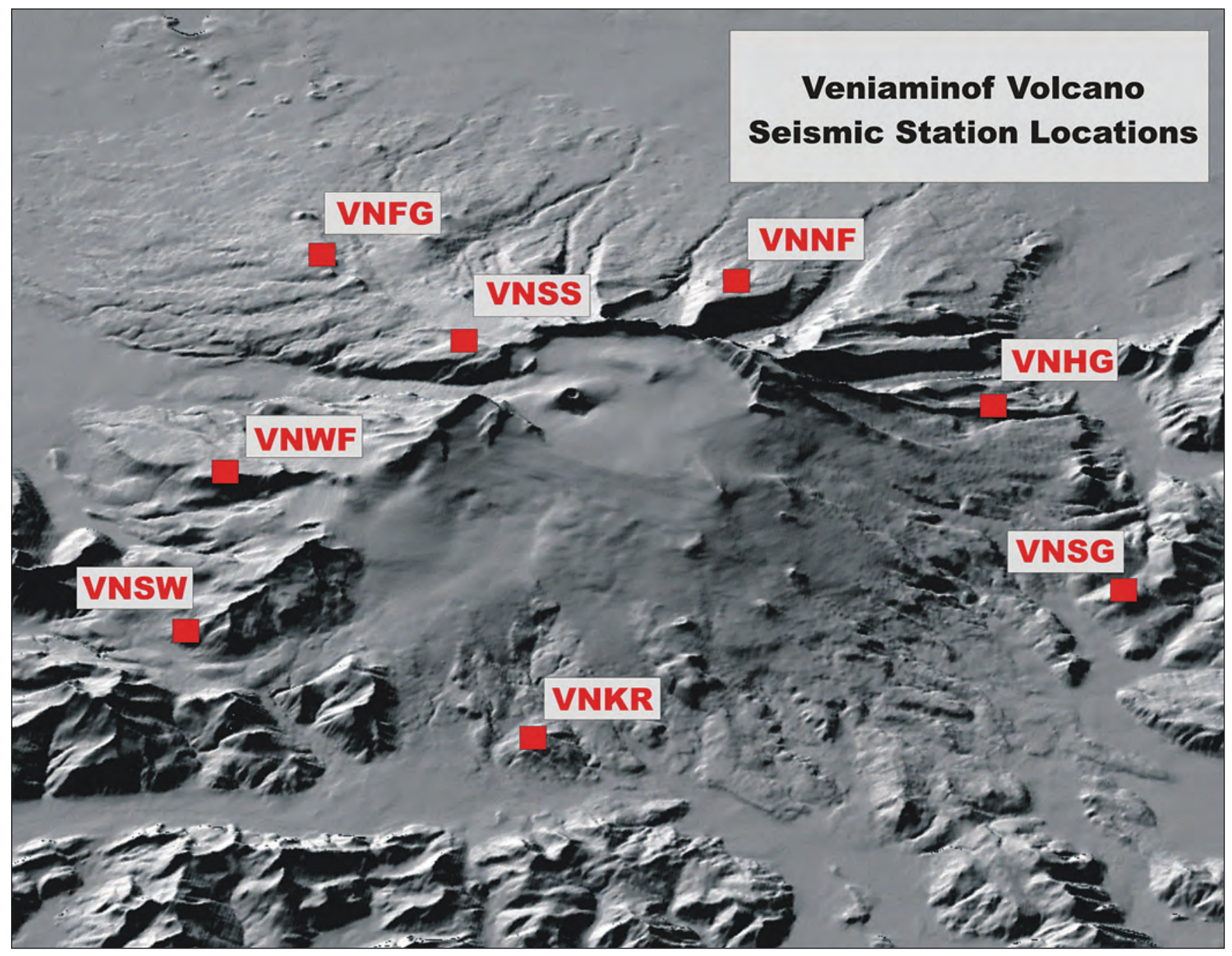

Figure 23. Veniaminof volcano showing the dimensions of this massive volcano, and the location of seismic stations. The active intracaldera cone is situated left of center within the caldera. Image courtesy of Janet Schaefer AVO/AKDGGS. AVO database image at URL: http://www.avo.alaska.edu/images/image.php?id=1293. 


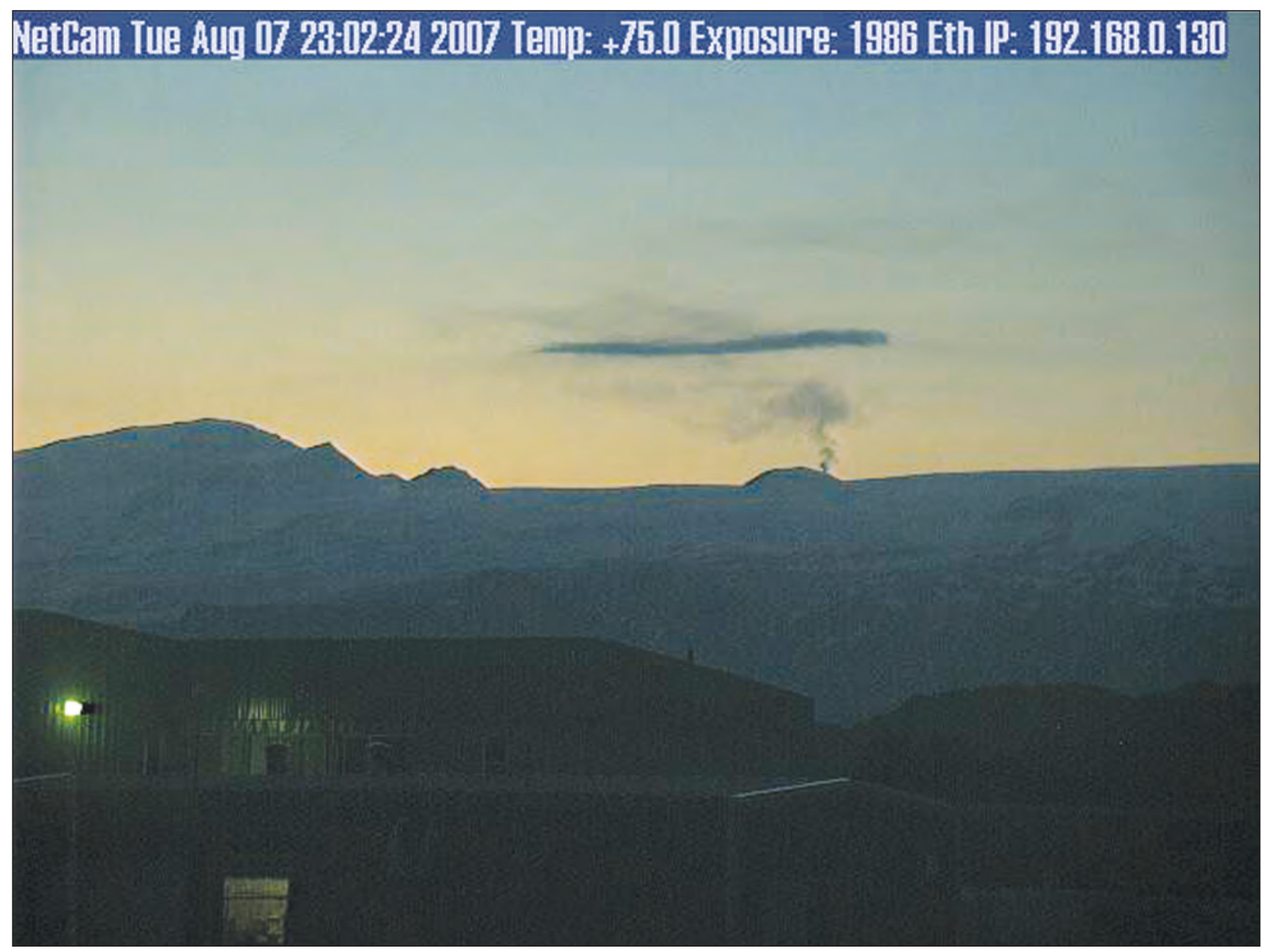

Figure 24. Web camera image showing a steam plume wafting up from the intracaldera cinder cone in Veniaminof caldera, August 7, 2007. The back-lighting made the plume appear "dark", but no ash was present. AVO database image at URL: http://www.avo.alaska.edu/images/image.php?id=29092. 


\title{
Pavlof Volcano
}

\author{
CAVW\# 1102-03-
}

$55^{\circ} 25^{\prime} \mathrm{N} 161^{\circ} 54^{\prime} \mathrm{W}$

$2,518 \mathrm{~m}(8,261 \mathrm{ft})$

Tip of Alaska Peninsula

\section{STROMBOLIAN ERUPTIONS}

Lava flow, minor ash clouds, lahars

Pavlof, one of the most frequently active volcanoes in the Aleutian arc, abruptly erupted on August 14, 2007, following an 11-year repose (fig. 25; cover photograph). The 31-day Strombolian eruption was preceded by less than 1 day of increased seismicity detected on the AVO seismic network, and produced a spatter-fed lava flow, minor ash clouds, and lahars that extended down the south flank into the sea. The following account is drawn in part from Waythomas and others (2008).

The previous eruption of Pavlof Volcano was September 1996-January 1997 (Neal and others, 1997; McGimsey and Wallace, 1999). Minor activity (snowmelt, ash dustings, steam plumes, sulfur emissions) was noted in 1999 and 2001, and in 2005, steaming was observed at adjacent Hague volcano (table 4b). Nothing unusual was observed during the summer of 2007 and the seismicity was at background levels through August 13. Abruptly on the morning of August 14, the 5-station seismic network on Pavlof began recording low-frequency earthquakes occurring at a rate of 2 to 7 events every 10 minutes, a pattern that had preceded eruptions in 1996, 1986, 1983, and 1981 (McNutt, 1987; McNutt, 1989; Roach and others, 2001). Although NWS observers in Cold Bay (37 mi southwest) with clear views of the volcano could see no anomalous steaming or other activity, and clear satellite views of the summit that morning also showed no signs of activity, the dramatic increase in seismicity prompted AVO to raise the Aviation Color Code/Volcano Alert Level to YELLOW/ADVISORY.

During the night, an intense thermal anomaly (TA) was visible in satellite images (Advanced Very High Resolution Radiometer-AVHRR), and seismic activity continued to increase in both number and duration of events per hour, clear signs that the unrest was escalating. On the morning of August 15 , based on observations of the TA and increasing seismicity, AVO elevated the Aviation Color Code/Volcano Alert Level to ORANGE/WATCH and announced that an eruption was expected. With the upgrade in color code, AVO began 24-hour surveillance of the volcano. Later in the day, AVO received eyewitness accounts from mariners of incandescent blocks rolling down the eastern-southeastern flank of the volcano during the previous night, beginning around midnight. Pilots reported a thin, low-level ash plume extending a few kilometers southwest from the summit. After receiving these reports, AVO established that the volcano was in eruption. Aerial photographs taken on August 15 show lava fountaining from a vent located about $200 \mathrm{~m}(650 \mathrm{ft})$ below the summit (fig. 26).

On August 16, strong seismic signals recorded at a single station (PVV), located $8.5 \mathrm{~km}$ (5.3 mi) southeast of the summit, heralded the passage of lahars down the south flank; more than 41 lahar events would be recorded by this station over the next 29 days. Satellite observations of a strong TA (fig. 27) and nighttime incandescence at the summit reported by local residents were indications of vigorous lava eruption at the summit vent (fig. 28). The seismic network recorded long periods of volcanic tremor with repetitive explosions that indicated nearly continuous Strombolian eruption. In addition to the generation of lahars, this activity produced low-level ash clouds (5-6 km ASL; 3.1-3.7 mi), and a spatter-fed lava flow that descended the southeastern flank. By August 18, AVO personnel in the field reported that vigorous eruption of lava at the summit continued. Using a Forward Looking Infrared (FLIR) camera, they determined that a 20- to 50-m-wide, 65 - to $165 \mathrm{ft}$-wide) $600^{\circ} \mathrm{C}\left(1,112^{\circ} \mathrm{F}\right)$ lava flow extended 565 $\mathrm{m}(1,850 \mathrm{ft})$ from the vent down the southeast flank (figs. 29 and $\underline{30}$ ). Thermal data collected the next day indicated that the outer part of this flow was about $140^{\circ} \mathrm{C}\left(284^{\circ} \mathrm{F}\right)$ and had cooled considerably. The vent crater for the last eruption of Pavlof, in 1996, was located on the upper northwestern side of the summit. For this eruption, the active vent migrated to the upper southeastern side, about $200 \mathrm{~m}$ (650 ft) below the summit (figs. 31-33). 


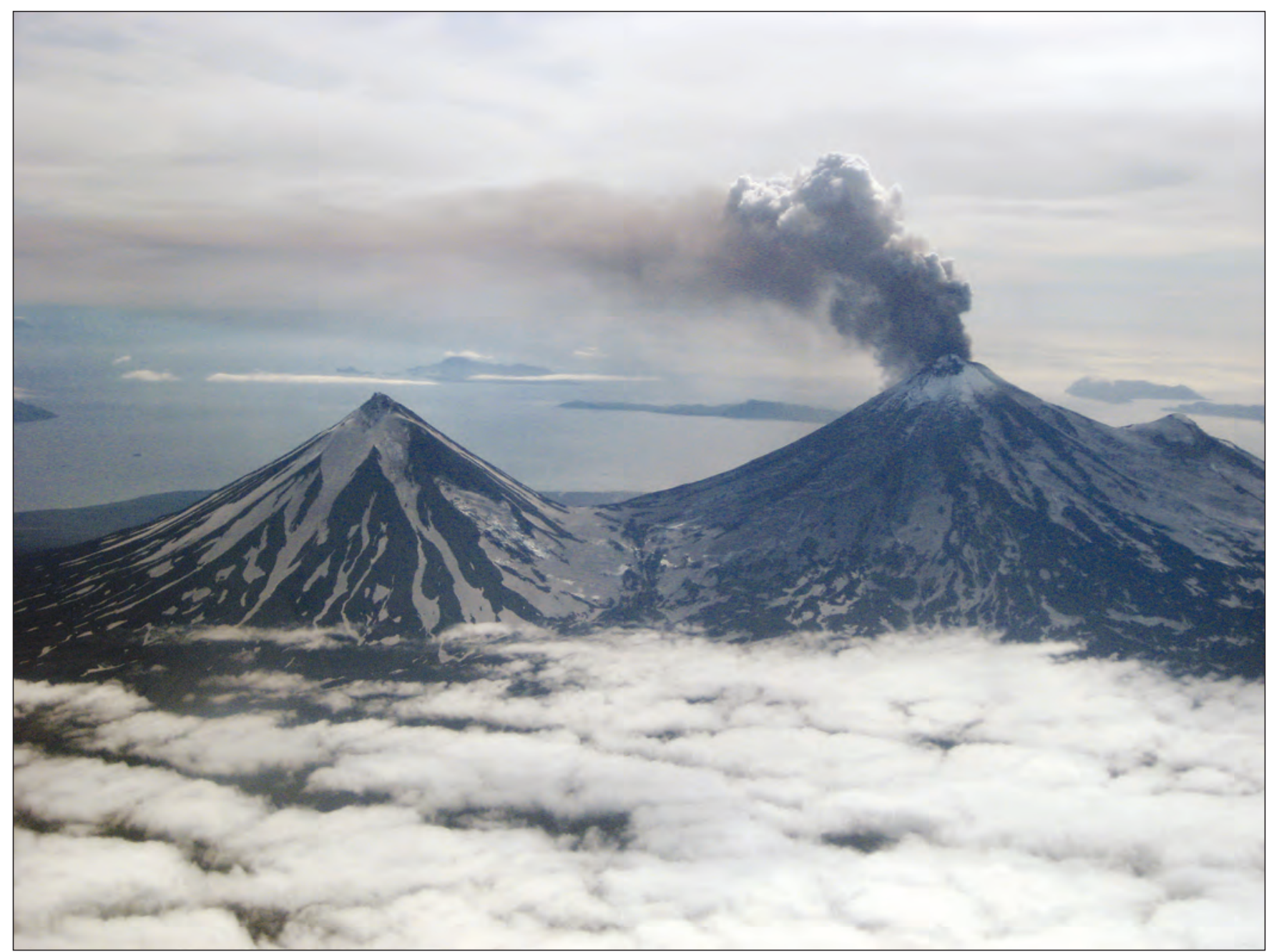

Figure 25. Steam and ash erupting from Pavlof Volcano, August 29, 2007. Pavlof Sister volcano-morphologically young but inactive historically — on the left. View is to the southeast. Little Pavlof (satellite cone) on far right. Photograph by Guy Tytgat, AV0/ UAFGI. AVO database image at URL: http://www.avo.alaska.edu/images/image.php?id=13504. 


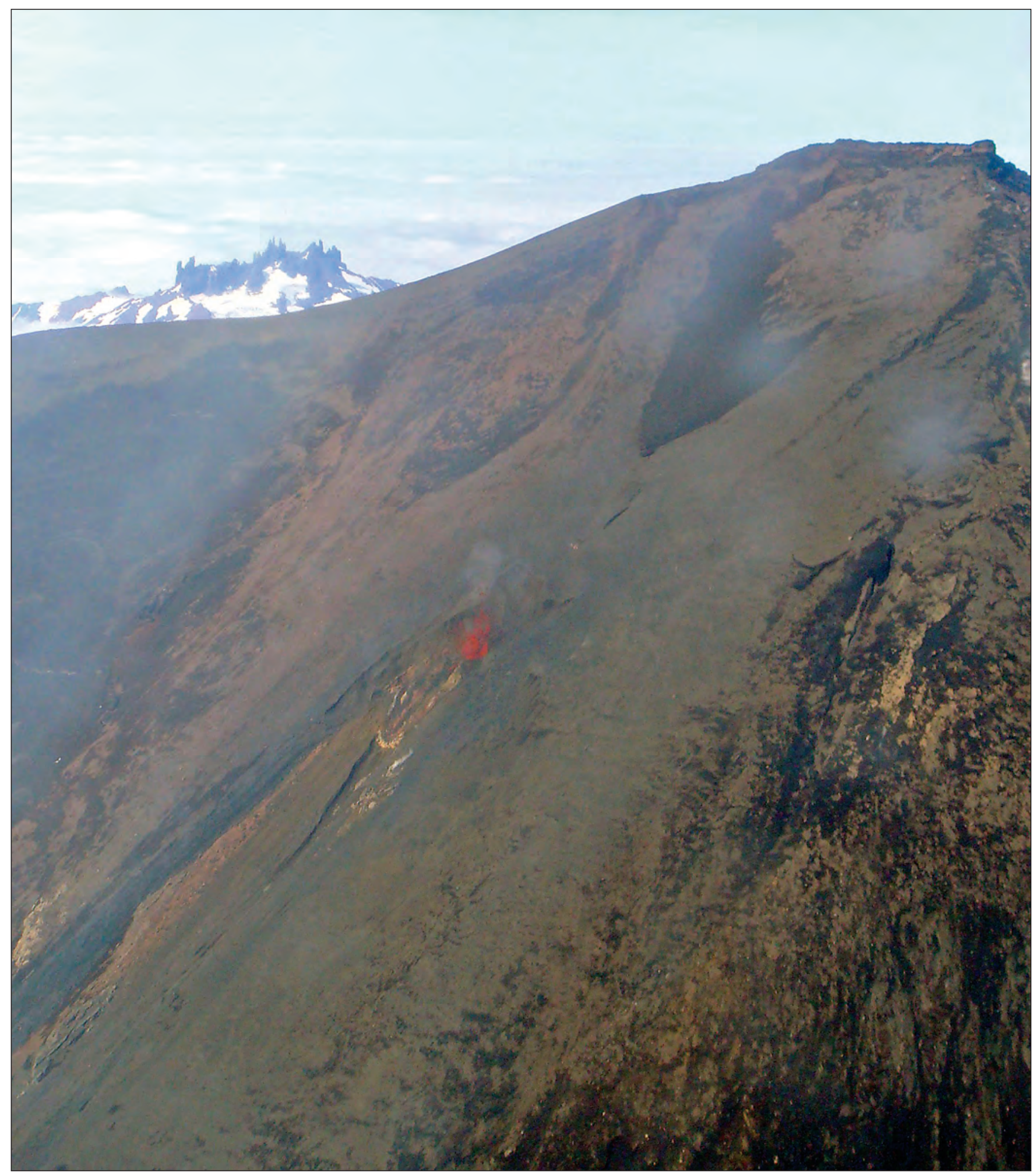

Figure 26. Upper southeast flank of Pavlof Volcano and incandescent lava fountaining from the active vent-here about $50-70 \mathrm{~m}$ $(160-230 \mathrm{ft})$ in diameter-during the 2007 eruption. The vent is $200 \mathrm{~m}(660 \mathrm{ft})$ below the summit. Photograph by pilot Adam Dimmitt, August 15, 2007, used with permission. AVO database image at URL: http://www.avo.alaska.edu/images/image.php?id=13411. 


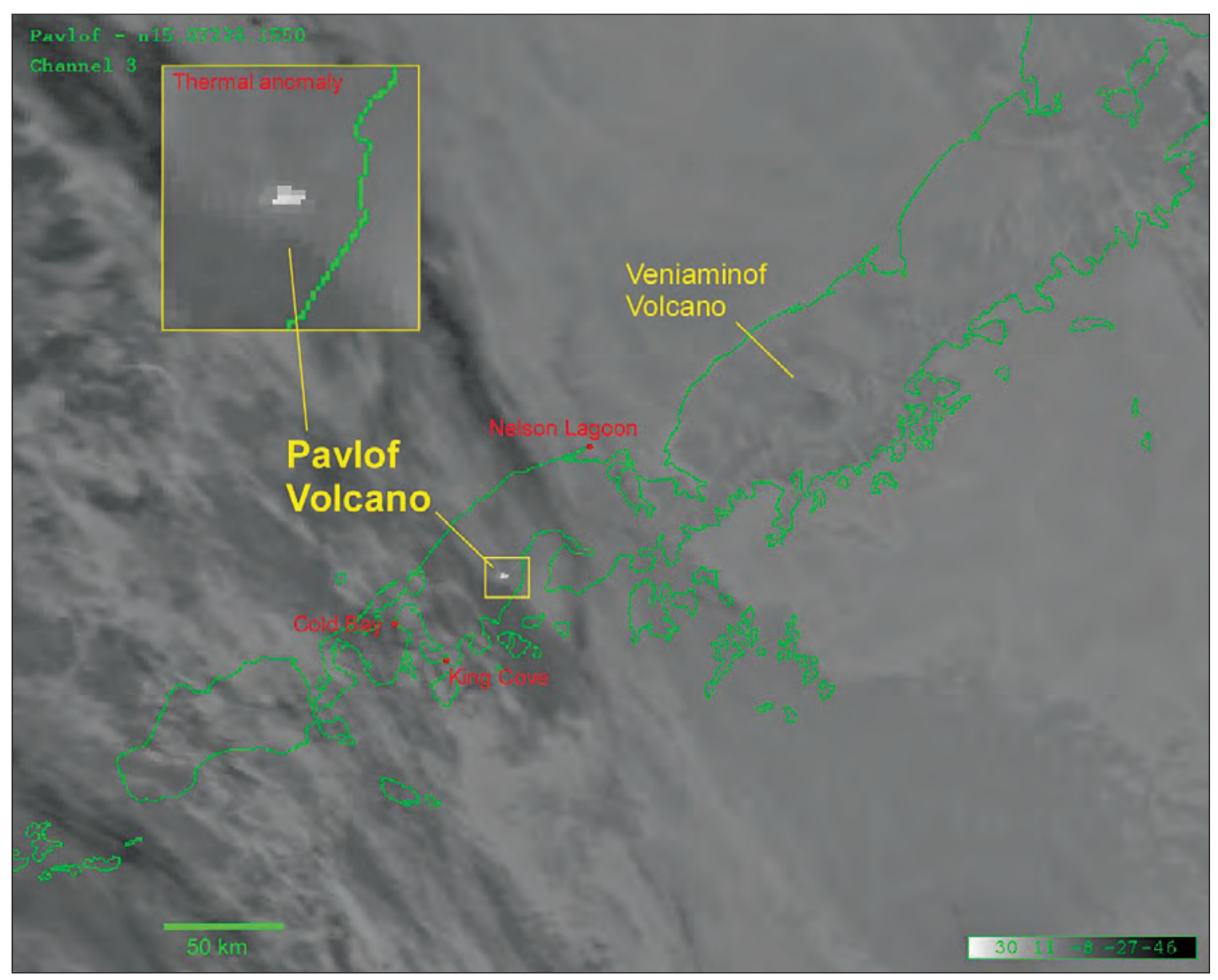

Figure 27. NOAA AVHRR satellite image showing a strong thermal anomaly observed at the summit of Pavlof Volcano, August 16, 2007 at 0750 AKDT (1550 UTC). In this image, white colors represent hot temperatures. Inset shows enlarged area of Pavlof vent region. These data are routinely provided within minutes of acquisition to the Alaska Volcano Observatory by both the UAF-GINA project and the NOAA/National Weather Service - Gilmore Creek station. Image courtesy Rick Wessels, AVO/USGS. AVO database image at URL: http://www.avo.alaska. edu/images/image. php?id=13410. 


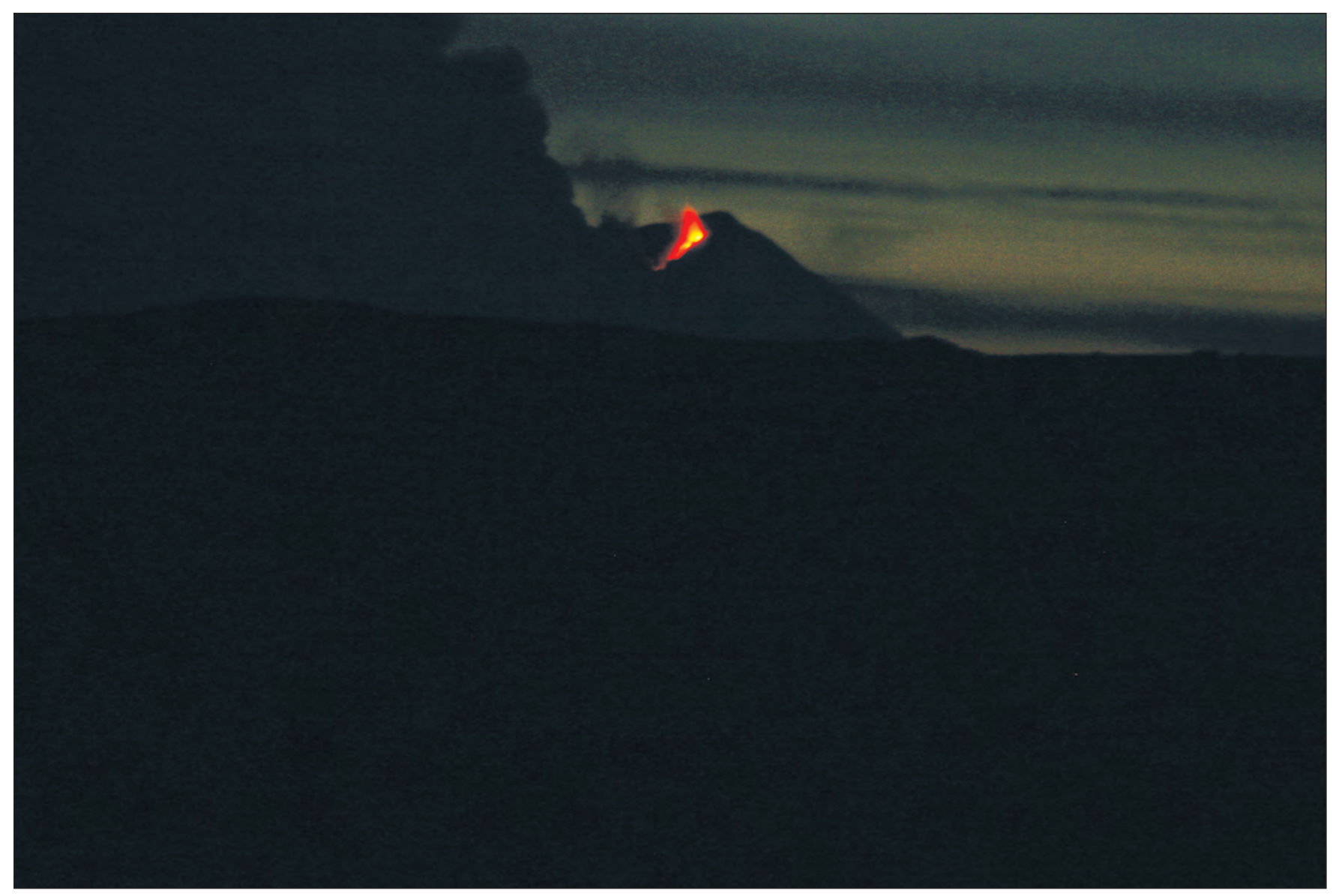

Figure 28. Steam and incandescent lava at Pavlof Volcano on the evening of August 28, 2007. Photograph by Cherilyn Lundgren, Aleutian East Borough, Sand Point, Alaska, used with permission. AVO database image at URL: http://www.avo.alaska.edu/images/ image.php?id=13509. 


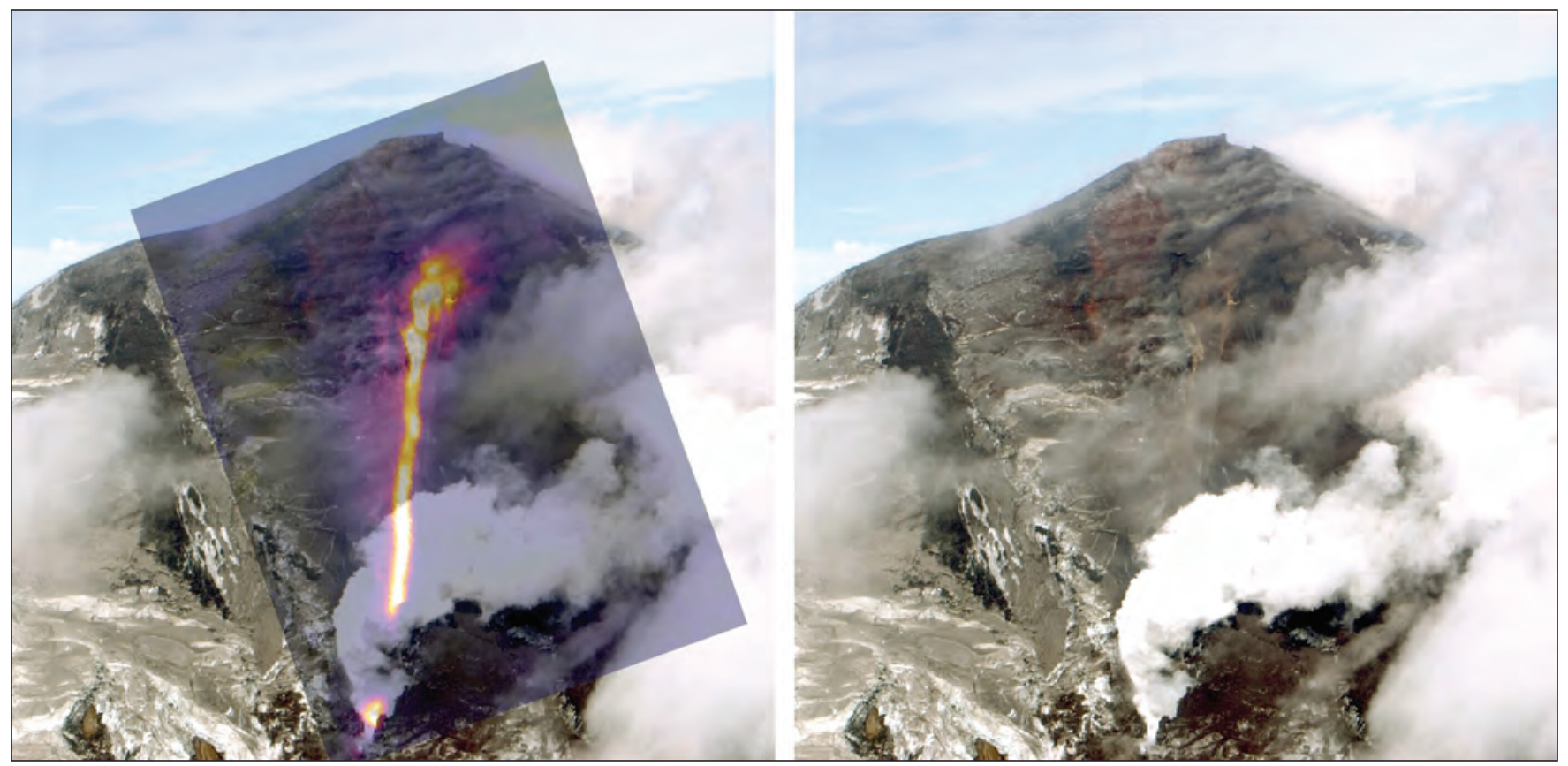

Figure 29. FLIR image (left) of the lava flow at Pavlof Volcano on August 18, 2007, viewed from the southeast placed in approximately the correct position over a photograph of the summit at about the same time (right). The vent area-a bowl-shaped, asymmetric scallop-is about $200 \mathrm{~m}$ ( $660 \mathrm{ft}$ ) below the summit. The lava flow is quite narrow ( $23 \mathrm{~m}$ or $75 \mathrm{ft}$ ) as it courses down the very steep (30+ degree) upper flank of Pavlof, confined to a channel that may be partially carved down into glacial ice and snow. FLIR image by Cyrus Read, AVO/USGS; compilation by Rick Wessels, AVO/USGS. AVO database image at URL: http://www.avo. alaska.edu/images/image.php?id=13475. 


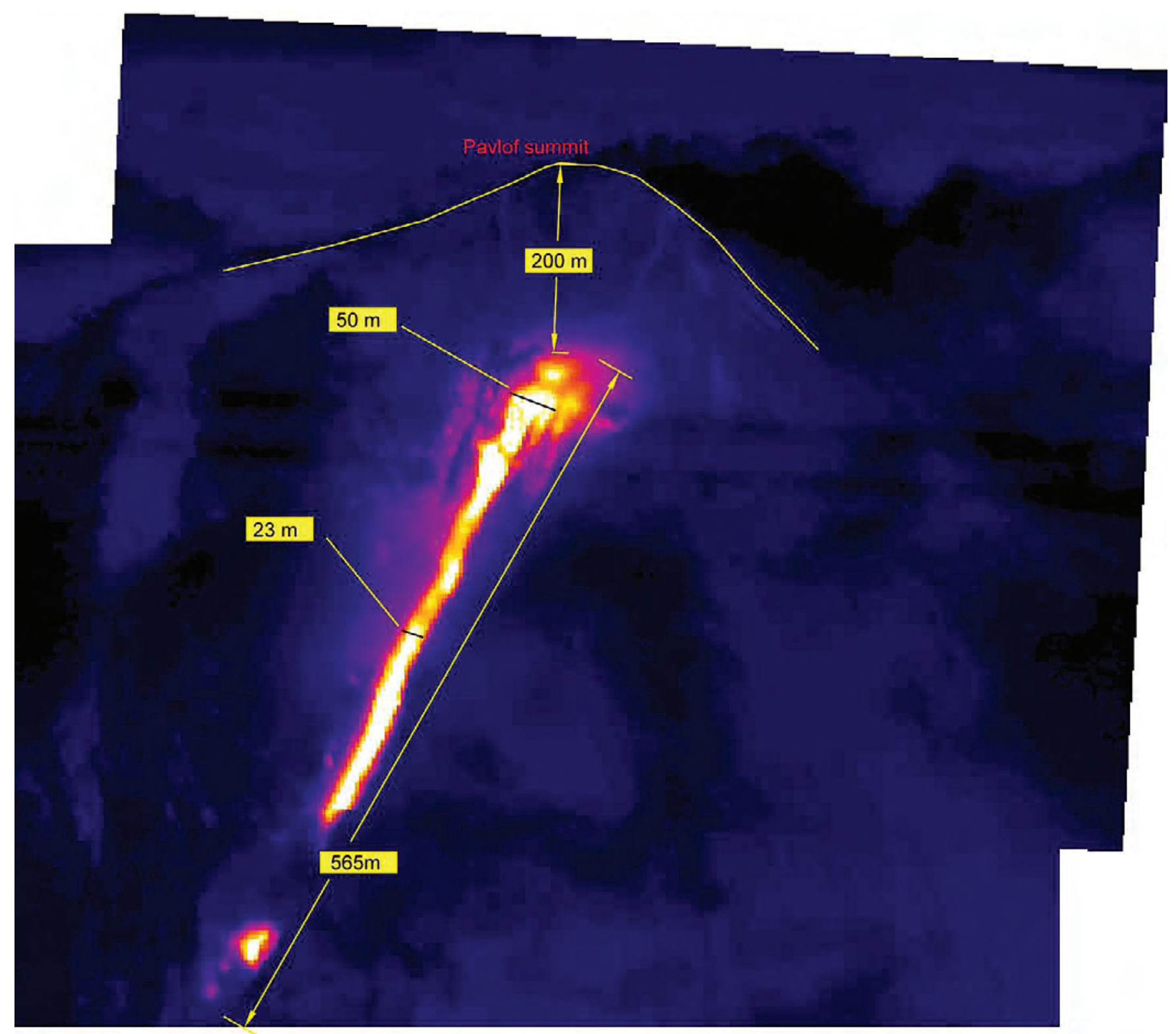

Figure 30. FLIR image of the upper southeast flank of Pavlof Volcano showing the vent area about $200 \mathrm{~m}$ ( $660 \mathrm{ft}$ ) below the summit of the volcano, August 18, 2007. The lava flow is quite narrow (23 m or $75 \mathrm{ft}$ ) as it courses down the very steep (30+ degree) upper flank of Pavlof, confined to a channel that may be partially carved into glacial ice and snow. Where the very hot (bright colors) become patchy, the lava flow and associated avalanches of lava blocks and fragments may be obscured by steam. Alternatively, the hot material may have eroded a deep, narrow channel into snow and ice and be out of view. Melting of snow and ice is producing constant flow of muddy water and debris down a deep canyon on the southeast flank and out onto the alluvial fan east of the volcano. Some of the larger lahars (mudflows) reached the Pacific 0cean, 11 km (7 mi) away. Image by Cyrus Read, AVO/USGS; interpretation and annotation by Rick Wessels, AVO/USGS. AVO database image at URL: http://www.avo.alaska.edu/images/image.php?id=13479. 


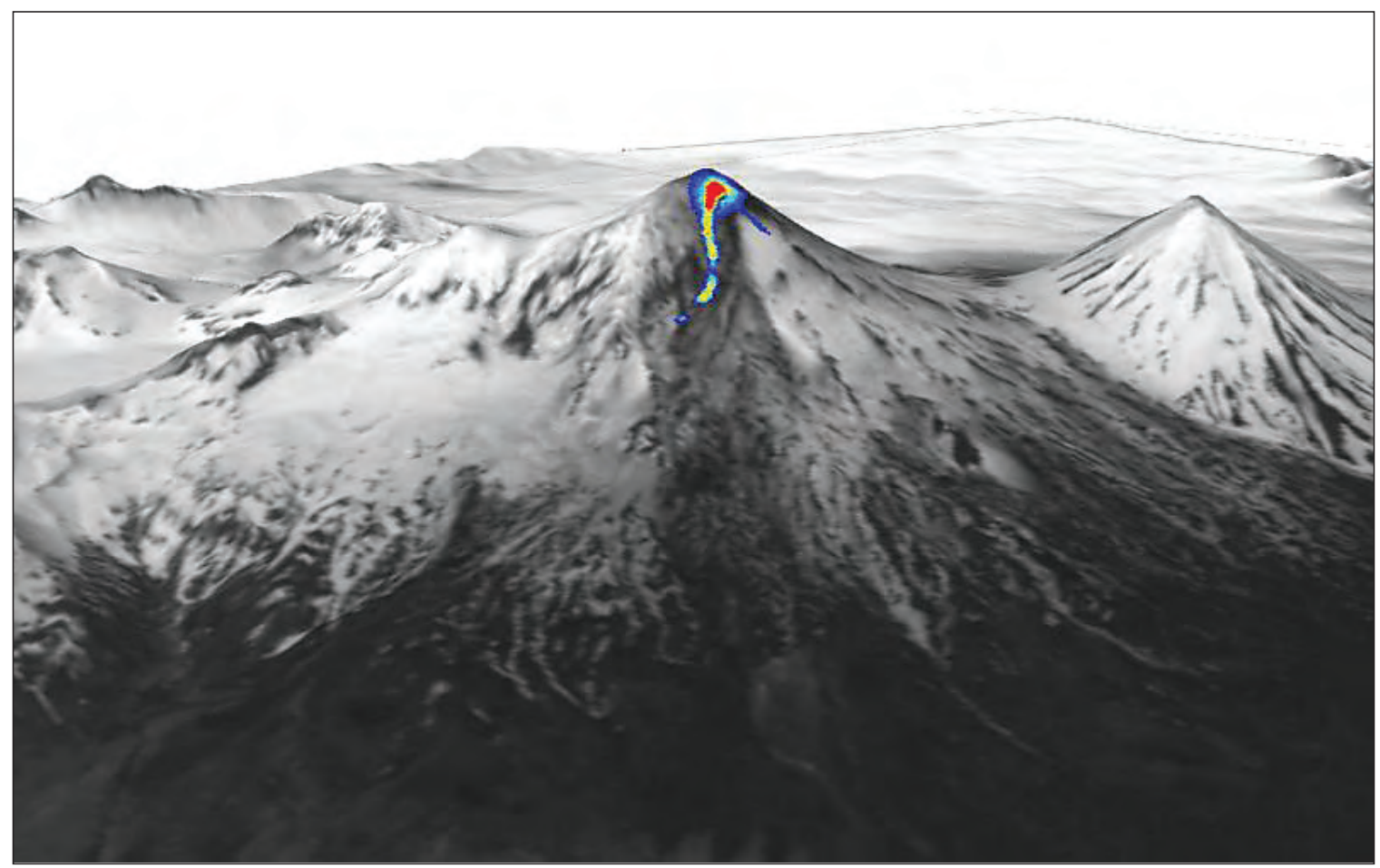

Figure 31. Oblique 3D perspective view of Pavlof on September 10, 2007, from the southeast of the hottest ASTER shortwave infrared (SWIR-30 m) pixels draped onto a June 23, 2007, daytime ASTER view. The ASTER TIR data show that the new Pavlof lava flow had grown and was now about $1.8 \mathrm{~km}$ (1.1 mi) long in map view. The length measured along downslope from the vent is approximately $2.1 \mathrm{~km}(1.3 \mathrm{mi})$. Image provided by Rick Wessels, AVO/USGS. AVO database image at URL: http://www.avo.alaska.edu/images/image.php?id=13571. 


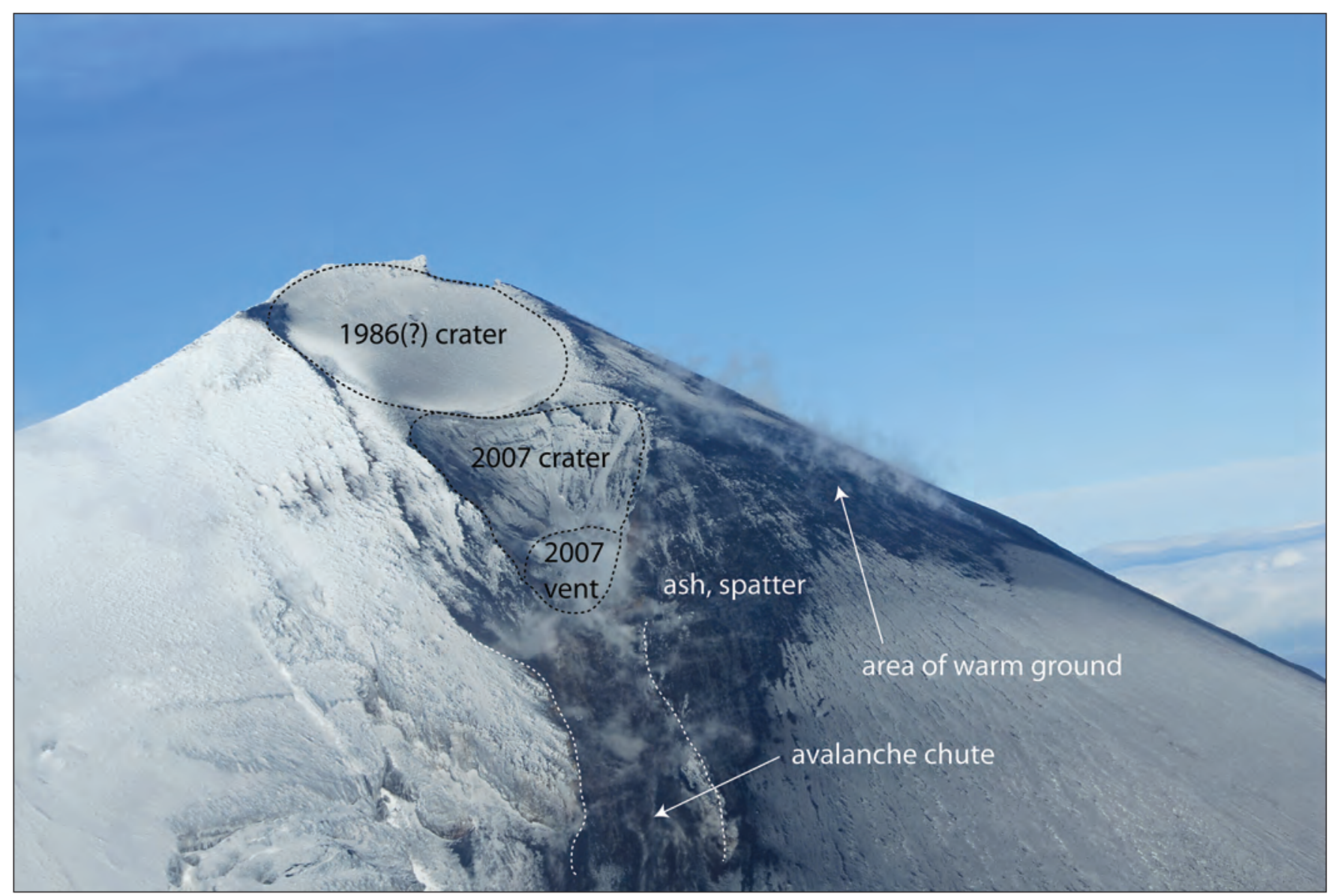

Figure 32. South side of the summit of Pavlof Volcano and various features and deposits, September 19, 2007. Photograph and annotations by Chris Waythomas, AVO/USGS. AVO database image at URL: http://www.avo.alaska.edu/images/image. php?id=13729. 


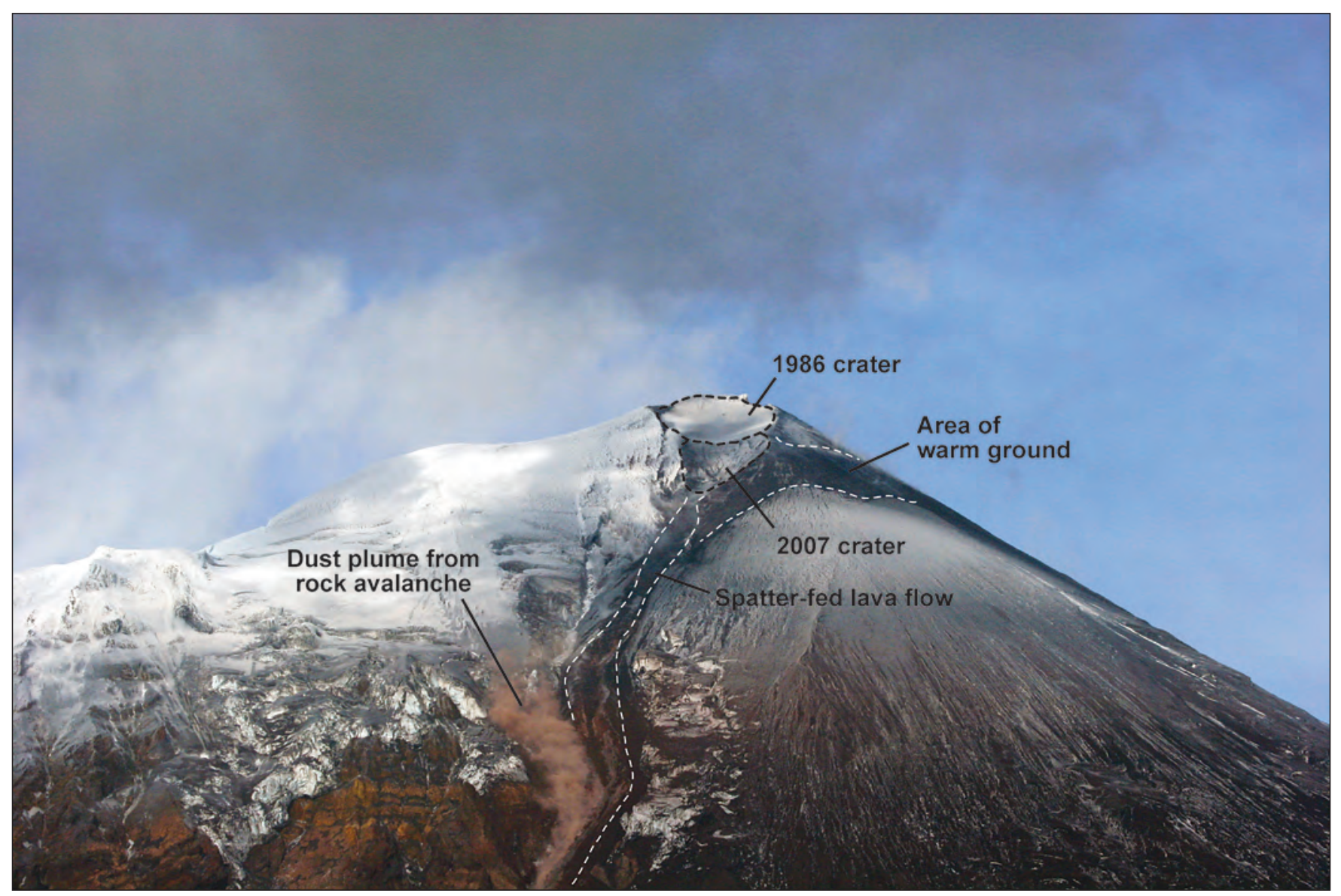

Figure 33. South flank of Pavlof Volcano and the 1986 and 2007 vents, spatter-fed lava flow chute, area of warm ground, and dust/ ash plume produced by small rockfall from the recently emplaced lava flow. Annotated photograph by Chris Waythomas, AVO/ USGS, September 19, 2007. AVO database image at URL: http://www.avo.alaska.edu/images/image.php?id=29312. 
Seismicity at Pavlof was elevated and steady throughout the remainder of August and then began waxing and waning for the first week of September. A strong TA was present in satellite images, even through clouds, during this time. During the second week of September, the seismicity began showing signs of a steady decrease (fig. 34), and by September 13, seismicity decreased to low levels and only a minor steam plume was visible above the volcano. A TA was last seen on September 15, and AVO declared that the activity had reached a lull by September 17. An AVO field crew with clear views reported that all eruptive activity had ceased during their visit on September 19, and the Aviation Color Code /Volcano Alert Level was downgraded to YELLOW/ADVISORY on September 20. The next 2 weeks of low seismicity and no further signs of activity or unrest prompted AVO to declare the eruption over (ending on September 13), and the Color Code/ Volcano Alert Level was downgraded to GREEN/NORMAL on October 5.

Ash, a blocky lava flow, and multiple lahars were generated by this eruption. Mixed ash and steam clouds produced during the most energetic eruptive period, midAugust to mid-September, reached altitudes of 5-6 km (about $20,000 \mathrm{ft}$ ) ASL. The plumes were diffuse, drifted primarily to the southeast over the North Pacific Ocean, and many could not be detected in satellite imagery. No ash reportedly fell on nearby communities and there were no significant impacts to aviation. AVO deployed a DRUM aerosol impactor (particle collector) in Sand Point, 90 km (56 mi) east of Pavlof, and collected fine ash $(2.5-0.1 \mu \mathrm{m})$. Although no visible ash fallout was observed during aerosol sampling, these results demonstrate that volcanic ash was present in respirable size fractions downwind of the volcano even during periods of low ash emissions (Peter Rinkleff and Cathy Cahill, AVO/UAFGI, written commun., 2010).

Analyzed samples from the lava flow are basaltic andesite in composition (53\% $\left.\mathrm{SiO}_{2}\right)$, which is similar to the products of previous Pavlof eruptions (McNutt and others, 1991; Neal and McGimsey, 1997). Lahars were produced by interaction of hot blocks and spatter from the lava flow with snow and ice on the southeastern flank. The lahars inundated an area over $2 \mathrm{~km}^{2}\left(0.78 \mathrm{mi}^{2}\right)$ and formed a debris fan that extended $3.6 \mathrm{~km}(2.2 \mathrm{mi})$ from the base of the volcano into Pavlof Bay (fig. 35).

Pavlof Volcano is located on the southwestern end of the Alaska Peninsula about $950 \mathrm{~km}$ (590 mi) southwest of Anchorage. The community of Cold Bay is located $60 \mathrm{~km}$ (37 mi) to the southwest of Pavlof. Pavlof is a steep-sided, symmetrical, 2,581-m-high (8,261 ft) stratovolcano. With almost 40 historic eruptions, it is the most active volcano in the Aleutian arc (Miller and others, 1998). Eruptive activity generally is characterized by Strombolian lava fountaining that typically continues for a several-month period. Hazards in the vicinity of the volcano include ash clouds, minor ash fall on nearby communities, mudflows, lava flows and avalanching of hot debris on the flanks of the volcano (Waythomas and others, 2006). The last eruption of Pavlof occurred September 1996 through January 1997 and produced spectacular fountains of lava, a lava flow, and ash clouds up to $9 \mathrm{~km}(30,000 \mathrm{ft}) \mathrm{ASL}$ (McGimsey and Wallace, 1999). The 1986 eruption produced an ash cloud that attained $15 \mathrm{~km}$ (49,000 ft) ASL. A 7-station seismic network was operating in 2007, and in response to the 2007 eruption, AVO installed an additional three temporary broadband seismometers that remained in place throughout the year and removed in 2008. 


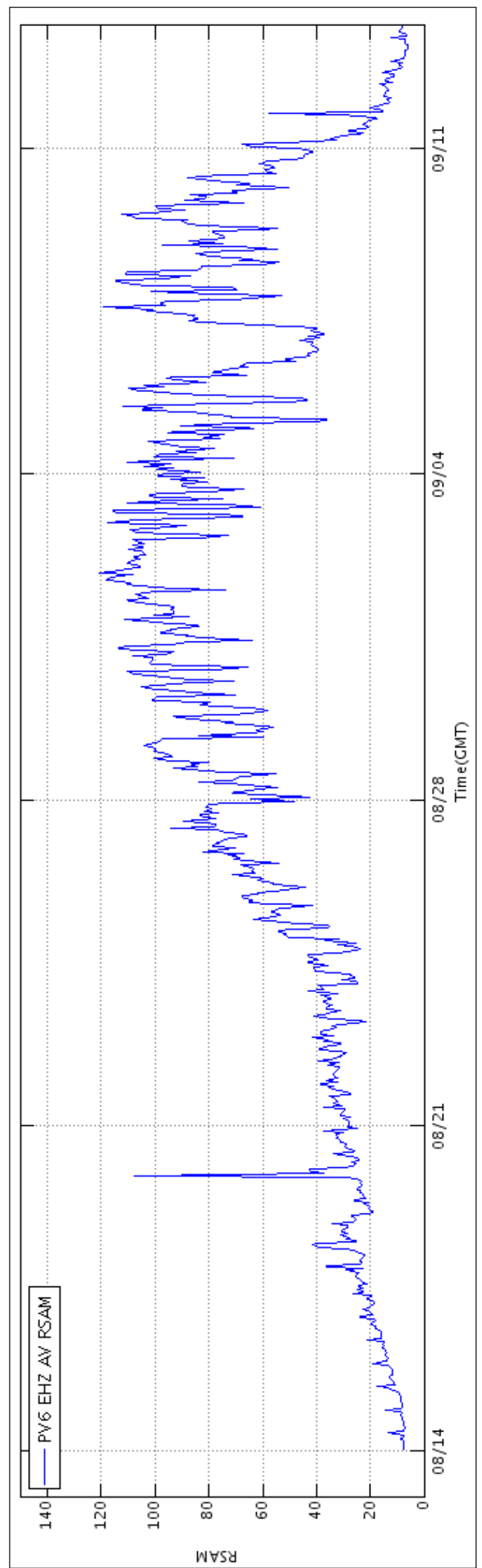

$\varangle$ 喜

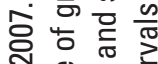

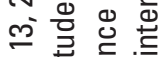

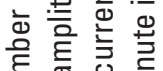

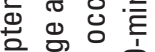

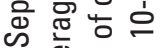

㐫离.

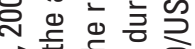

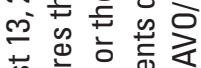

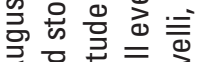

定踣

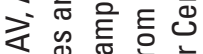

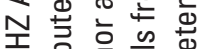

山

a

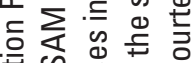

西究

is

㐫

बह

늠워

ते

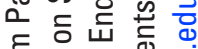

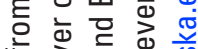

c. 잉

के क्षे

$\frac{\pi}{0} \sum^{2}$

용

$\subseteq$ is

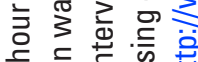

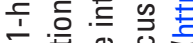

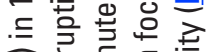

㐫高壳

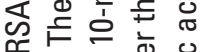

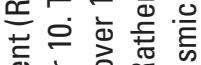

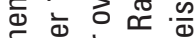

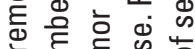

今

웡히

造

。

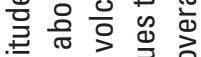

들 들

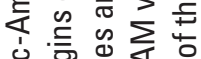

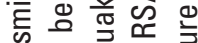

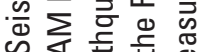

产焉 đ

눙

ه d

मे 离

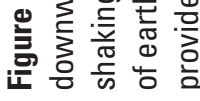




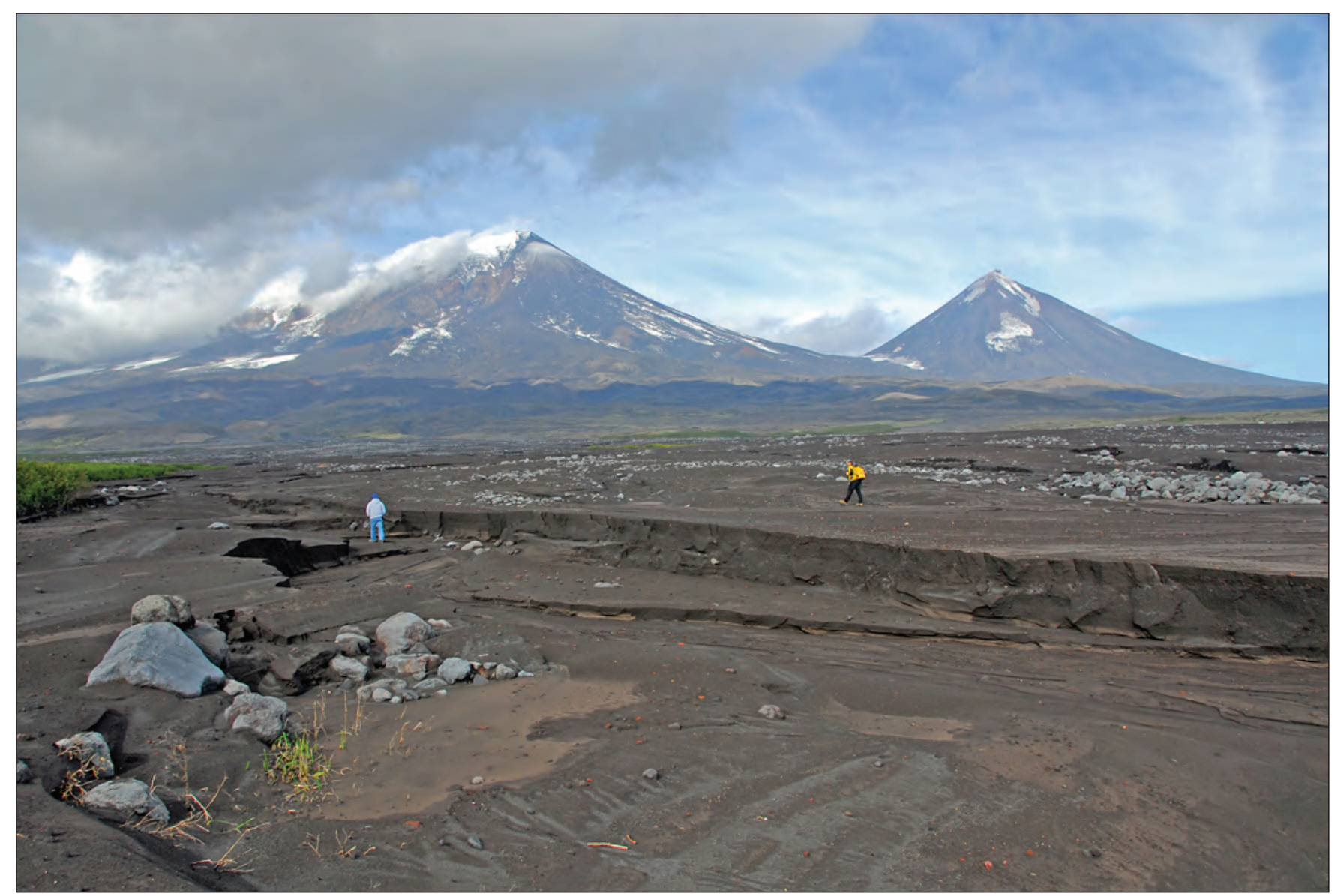

Figure 35. Lahar deposits produced by the August-September 2007 eruption of Pavlof Volcano. View is to the northwest; Pavlof on left and Pavlof Sister on the right. These deposits consist mostly of sandy matrix-supported granular gravel. Lahars inundated a $2 \times 10^{6}$ square-meter (about 500 acres) area with a volume of approximately $3 \times 10^{6} \mathrm{~m}^{3}\left(3.9 \times 10^{6} \mathrm{yds}\right)$ of debris (Waythomas and others, 2008; Waythomas, AVO/USGS written commun., 2010). Photograph by Chris Waythomas, AVO/USGS, September 19, 2007. AVO database image at URL: http://www.avo.alaska.edu/images/image.php?id=13716. 


\author{
Akutan Volcano \\ CAVW\# 1101-32- \\ $54^{\circ} 25^{\prime} \mathrm{N} 165^{\circ} 58^{\prime} \mathrm{W}$ \\ $1,303 \mathrm{~m}(4,275 \mathrm{ft})$ \\ Akutan Island, eastern Aleutian Islands \\ TRIGGERED SEISMICITY; INFLATION; STEAMING
}

Akutan is one of several Alaska volcanoes at which seismicity was triggered by the M8.2 earthquake generated in the Kurile Islands on January 13, 2007, 0423 UTC (see section, "Wrangell volcano"). Four of the seven largest triggered Akutan events, ranging in magnitude from 0.0 to 0.5 and depths from 0.86 to $-2.17 \mathrm{~km}$, were located (fig. 36; John Power, AVO/USGS, written commun., 2010). The earthquake locations fall along the trend of intense seismicity and ground breakage that occurred in March 1996 at Akutan (Neal and others, 1997; Waythomas and others, 1998, fig. 10; Lu and others, 2005). The AVO Akutan seismic network was installed in the summer of 1996, and this was the first instance of observed triggered seismicity at Akutan; however, it was shortlived and did not result in any detectable surface disturbance.

In early October 2007, AVO remote sensors using GPS time series for Akutan detected signs of renewed inflation over the previous month of the west flank, the same area that inflated during the 1996 seismic crisis. A few days later, on October 8, the manager of the Trident seafood processing plant called to alert AVO of "strong steaming" from a "new" area in the Hot Springs Bay valley (fig. 37). Long-known thermal springs occur along the lower course of the stream draining the valley, and the photograph of figure 37 shows a steam column apparently rising from further up-valley of the springs area. This also is the area of maximum deflation following the 1996 seismic swarms. No unusual seismic activity was noted for the period of west-flank inflation or this steaming episode. This location for a steam plume was considered "new" by local observers because the lower-valley thermal springs rarely emit a concentrated, vertically rising plume of steam and most reports of steaming arise from the prominent fumarole field located at the 1,500-ft-level of the eastern flank at the headwaters of Hot Springs Bay valley (fig. 38).

Akutan is one of the most active volcanoes of the Aleutian arc having erupted at least 31 times since 1790, most recently in 1992 (McGimsey and others, 1995). Occupying the western half of Akutan Island, the volcano is a symmetrical stratocone with a 2-km-diameter (1.2 mi) circular summit caldera (figs. 38 and 39). The caldera is breached to the northwest, and an active intracaldera cinder cone about $200 \mathrm{~m}$ (656 ft) high has been the site of all historical eruptive activity (Richter and others, 1998; Waythomas and others, 1998). The City of Akutan is $13 \mathrm{~km}$ (8 mi) east of the caldera rim, and one of the largest region seafood-processing plants (Trident) is located $1 \mathrm{~km}(0.6 \mathrm{mi})$ west of the city. In March 1996, two strong swarms of earthquakes struck the island, causing minor damage and prompting some residents and seafood-processing plant workers to leave the island ( $\mathrm{Lu}$ and others, 2000). The March 11 swarm involved more than 80 earthquakes M3.0 or greater and the largest was M5.2. The March 13 swarm had more than 120 M3.0 events, largest being M5.3 (Waythomas and others, 1998). The seismicity occurred along a northwestsoutheast trend across the upper north-northeast flank of the volcano, and caused dramatic linear ground breakage; interpreted as a dike emplacement event. A permanent seismic network was installed the summer of 1996 and currently consists of 12 stations -7 short-period, and 5 broadband stations. In 2007, PBO operated 8 GPS stations - 4 with tiltmeters-on Akutan. 


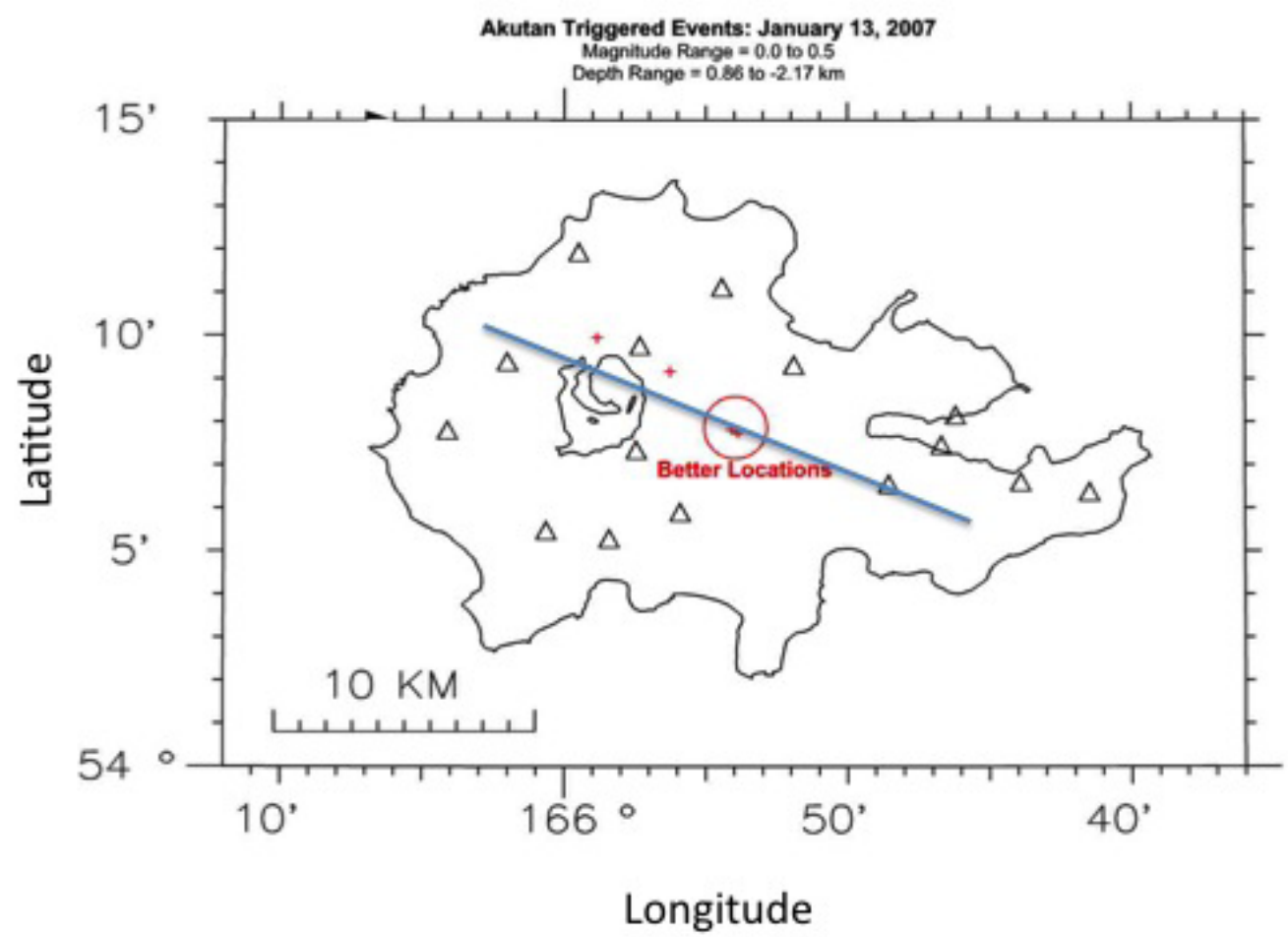

Figure 36. Seismicity at Akutan volcano triggered by the January 13, 2007, M8.2 Kurile Islands earthquake (the event occurred at 0423 UTC, January 13, 1923 AKST, January 12). Pictured are locations for the four largest events (red dots). They lie along the same trend (blue line) as that of intense seismicity with accompanied ground breakage that occurred during dike intrusion in March 1996 (Waythomas and others, 1998). Triangles mark locations of seismic stations. Plot of earthquake locations by John Power (AVO/USGS, written commun., 2010). 


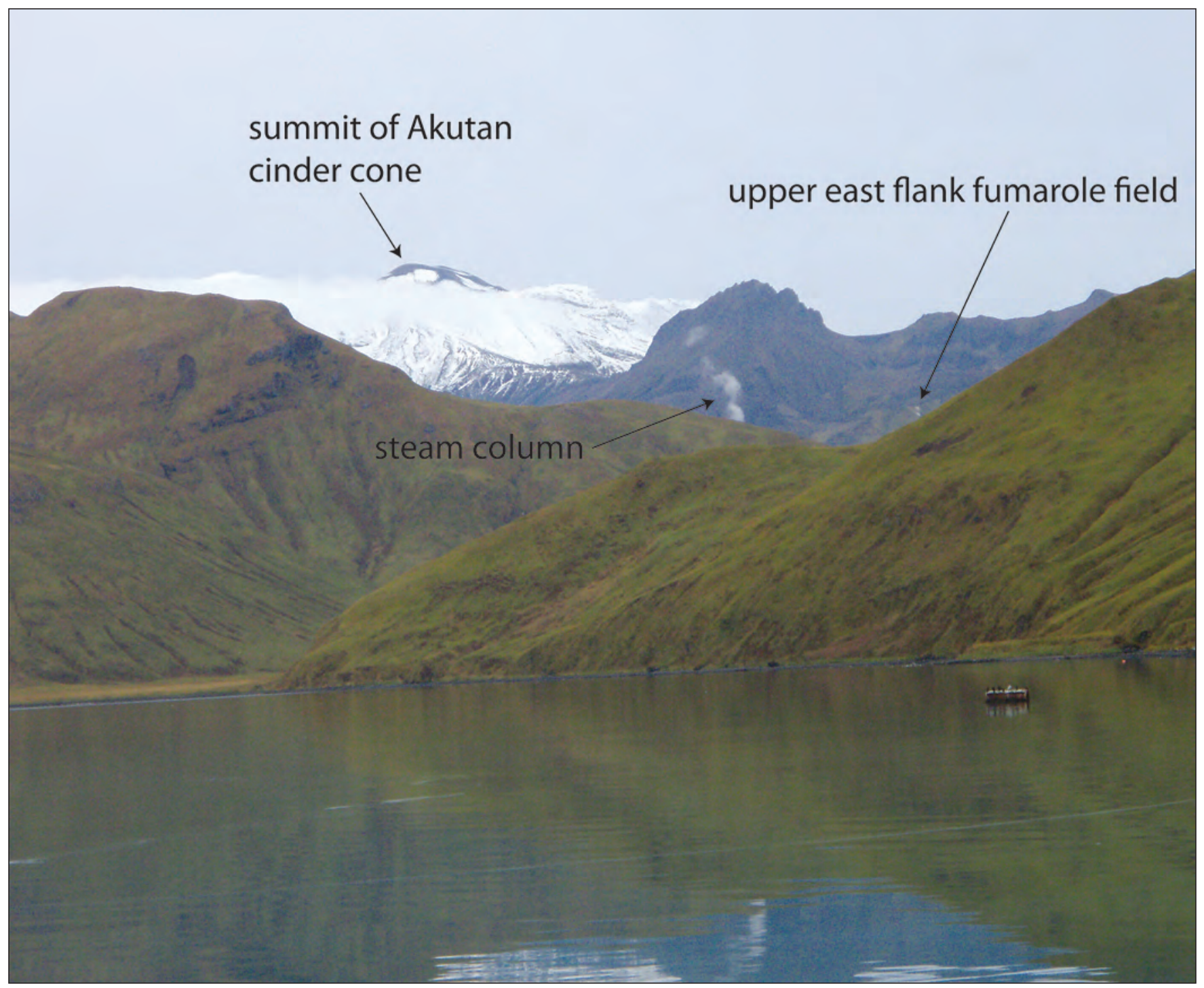

Figure 37. Steam column rising from upper Hot Springs Bay, a prominent valley draining the east flank of Akutan volcano. The dark summit of Akutan's intracaldera cinder cone is visible on the skyline above a thin layer of clouds. The photograph was taken on October 8, 2007, by Dave Abbasian, manager of Trident Sea Foods, from the plant located about $13 \mathrm{~km}$ from the east caldera rim. A prominent fumarole field occurs about midway up the east flank (1,500 ft level) and this column of steam appears to be rising from a location lower on the flank, perhaps closer to the valley bottom. Dave Abbasian reported that he had seen steaming from this area earlier in the summer and considered it to be a "new" area. AVO database image at URL: http://www.avo.alaska.edu/images/image. php?id=28872. 


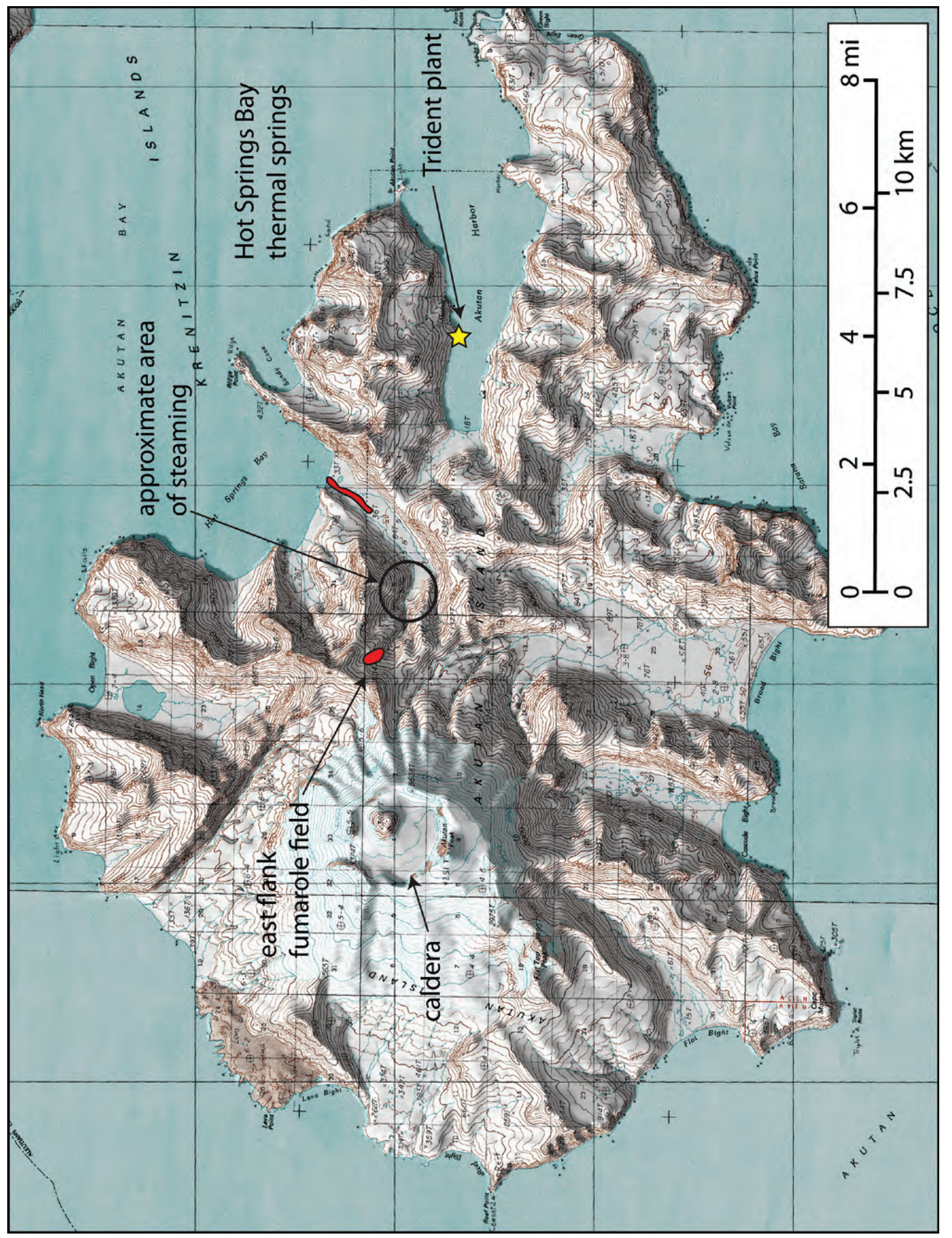

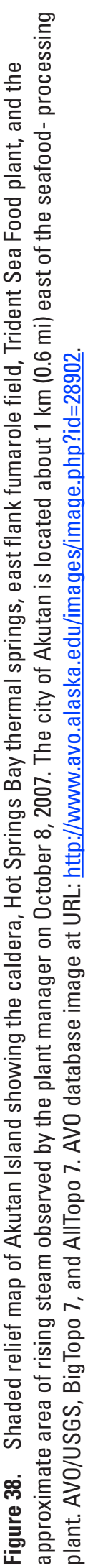




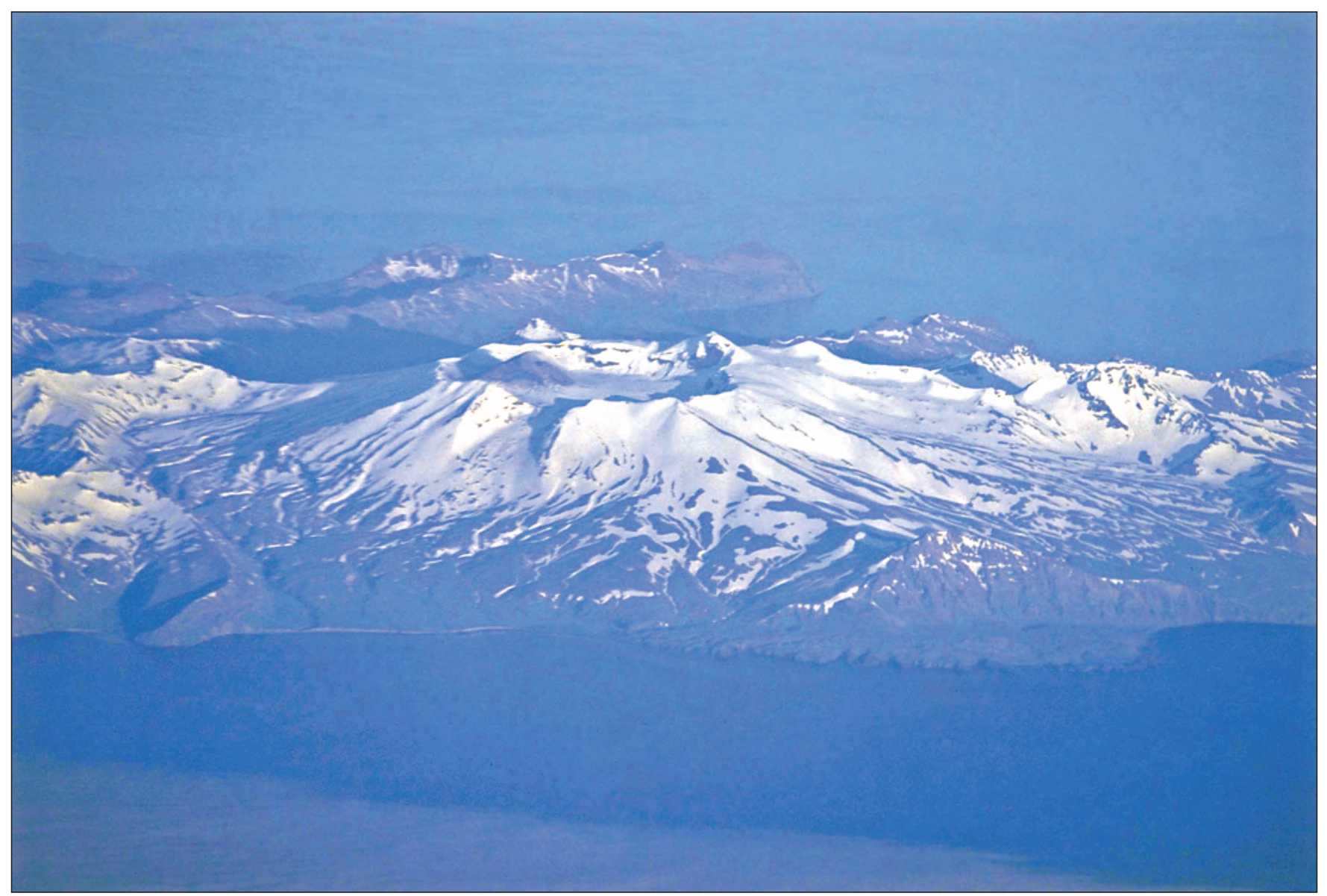

Figure 39. Oblique aerial photograph of Akutan volcano, June 28, 2000. The view is from the northwest, through the north-rim breach in the caldera with the active cinder cone visible inside the crater. The distant promontory is Battery Point, overlooking Broad Bight. Photograph by Chris Waythomas, AVO/USGS. AVO database image at URL: http://www.avo.alaska.edu/images/image. php?id=14064. 


\section{Cleveland Volcano}

CAVW\# 1101-24-

$52^{\circ} 49^{\prime} \mathrm{N} 169^{\circ} 57^{\prime} \mathrm{W}$

$2,730 \mathrm{~m}(5,676 \mathrm{ft})$

Chuginadak Island, east-central Aleutian Islands

INTERMITTENT EXPLOSIONS

Thermal anomalies, minor ash and gas emissions, flow and ballistic deposits

Cleveland volcano on Chuginadak Island in the central Aleutians (fig. 1) is unmonitored by ground-based instrumentation. Thick cloud cover often limits even satellite remote sensing abilities to reliably detect thermal anomalies and ash clouds resulting from explosions. Cleveland is frequently active and typically produces intermittent explosions with small to moderate ash plumes, ballistics, and Strombolian activity that generates water and debris flows down the flanks. Most unrest is accompanied by thermal anomalies detected in satellite images. Activity at Cleveland in 2007 generally was a continuation of that which occurred intermittently in previous years since 2001 when the last episode of significant eruptions occurred (table 5; Dean and others, 2004; Neal and others, 2008b).

Cleveland began 2007 in Aviation Color Code YELLOW and Volcano Alert Level ADVISORY following intermittent eruptive activity throughout 2006 (Neal and others, 2008b). Discussions in weekly AVO staff meetings, during January and early February 2007, on downgrading Cleveland to Aviation Color Code GREEN were interrupted by the detection of new thermal anomalies (table 5). Satellite data from February revealed evidence of recent activity involving ejection of bombs and debris on the upper flanks and generation of water-rich flows that travelled halfway to the coast. No ash emissions or ash fall deposits were observed. This level of activity-accompanied by persistent thermal anomaliesoccurred throughout the spring and early summer. On July 20, an intense thermal anomaly (fig. 40) was accompanied by a steam and gas plume visible in satellite images (fig. 41), and mariners in the area reported low-level ash emissions (fig. 42). Several small $\mathrm{SO}_{2}$ plumes were detected in Ozone Monitoring Instrument (OMI) satellite data (Dave Schneider, AVO/USGS, written commun., 2010). The ash and $\mathrm{SO}_{2}$ emissions signaled an increase in eruptive activity prompting AVO to raise the Aviation Color Code and Volcano Alert Level to ORANGE/ WARNING.

Over the next 3 weeks, thermal anomalies were observed when weather conditions allowed for clear views, but no steam or ash emissions were observed. A pilot got a close view of the summit crater on July 27 and reported evidence of recently emplaced debris including blocks rimming the crater and sulfur deposition (ig. 43).

A new Web camera aimed at Cleveland was installed in Nikolski, $75 \mathrm{~km}$ (45 mi) to the east, on August 6, but poor weather frequently precluded imaging the volcano. During the last 2 weeks of August, thermal anomalies decreased in size and intensity. The Aviation Color Code and Volcano Alert Levels were downgraded to YELLOW/WATCH on September 6 in response to the apparent waning of eruptive activity. Thermal anomalies continued to be observed, but with lower temperatures and intensities (fig. 44).

Retrospective analysis of seismic data from stations located on Umnak Island, and distant pressure sensors (table 5), suggested that an explosion occurred at Cleveland on October 3, 2007. No other evidence of this activity was forthcoming. Thermal anomalies continued to be seen through mid-November, visible during the few non-cloudy satellite views. During late November and through December, no thermal anomalies or activity were reported, and Cleveland ended 2007 in Aviation Color Code/Volcano Alert Level YELLOW/ADVISORY.

As in 2006, AVO tracked and responded to Cleveland activity in 2007 by relying heavily on remote sensing of the volcano and rapid response to reports received from pilots or other sources. Automatic PUFF runs of hypothetical ash trajectories appeared on the PUFF Website at URL: http://puff. images.alaska.edu/monitoring.shtml.

Cleveland volcano forms the western part of Chuginadak Island, an uninhabited island in the Islands of Four Mountains group in the east-central Aleutians. Cleveland is located about $75 \mathrm{~km}$ (45 mi) west of the community of Nikolski, and 1,500 km (940 mi) southwest of Anchorage. Historical eruptions have been characterized by short-lived ash explosions, lava fountaining, lava flows, and pyroclastic avalanches down the flanks. In February 2001, after 6 years of quiescence, Cleveland had three explosive events that produced ash clouds as high as $12 \mathrm{~km}$ (39,000 ft) ASL (Dean and others, 2004), a rubbly lava flow, and a hot avalanche that reached the sea. Intermittent explosive eruptions have occurred in every year since 2001. In fact, the current activity may be considered a continuation of the 2001 unrest.

AVO has no seismic instruments located on Chuginadak Island, and therefore monitoring of Cleveland volcano is accomplished by analyzing daily satellite images, occasional pilot and mariner reports, and on rare clear days, a Web camera located in Nikolski (http://www.avo.alaska.edu/ webcam/Cleveland.php). 
Table 5. 2007 activity at Cleveland volcano, compiled from Alaska Volcano Observatory information-release statements, internal-log entries, and summaries.

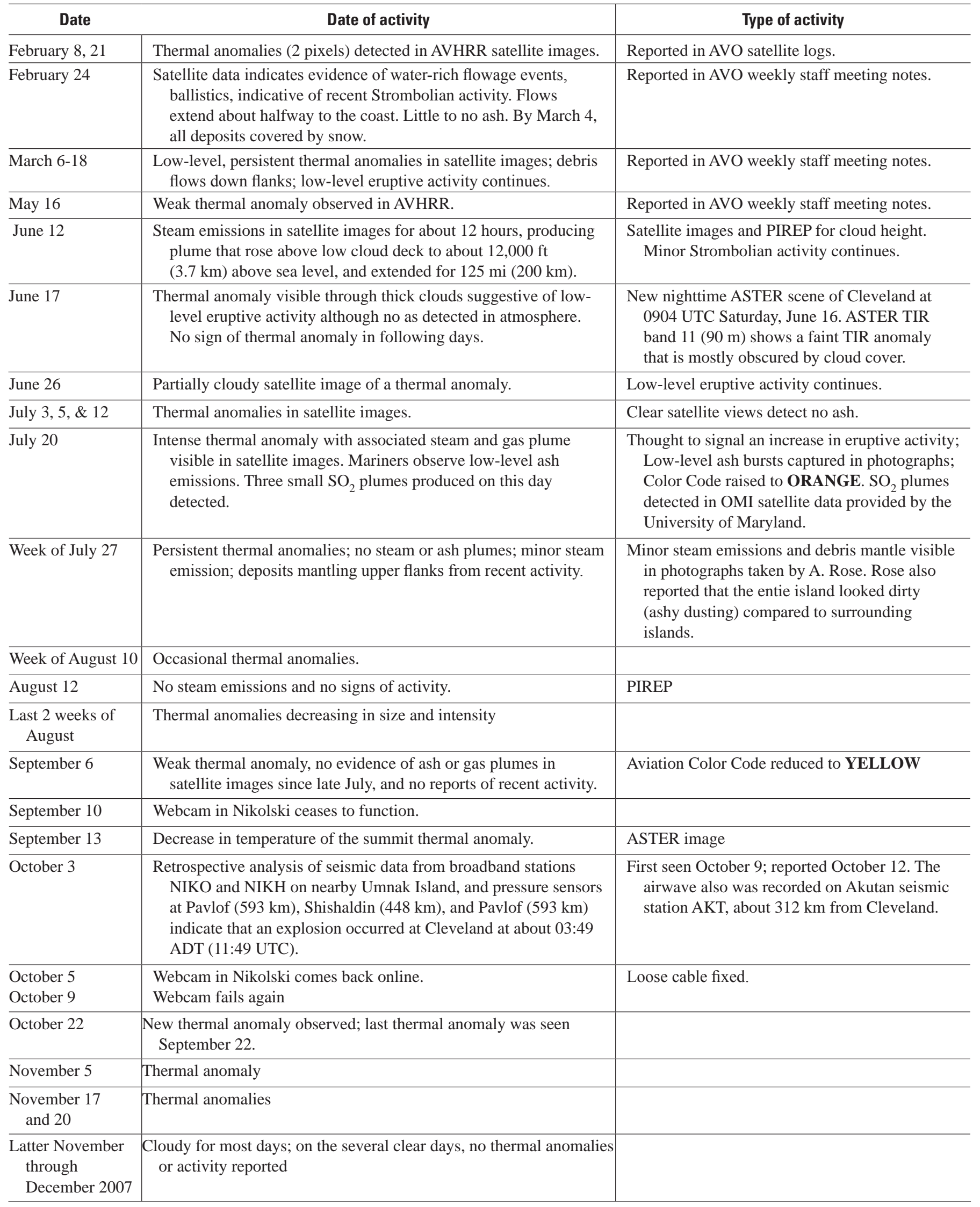




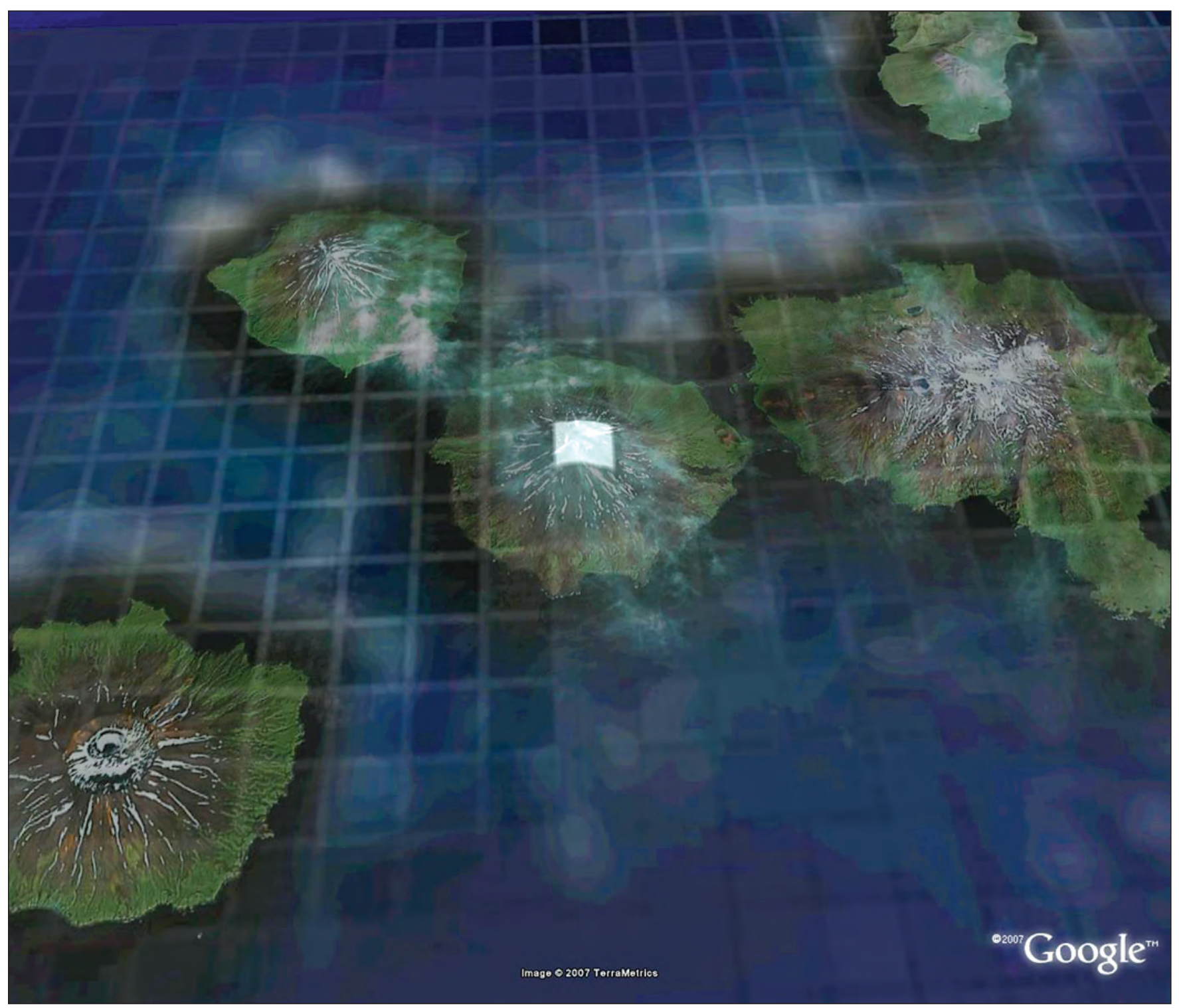

Figure 40. Satellite image of a thermal anomaly and an associated steam plume at Cleveland volcano on the morning of July 20, 2007, suggesting that low-level eruptive activity was occurring. An AVHRR image from Monday, July 23 (0844 UTC) is placed as an overlay on a Google ${ }^{\circledR}$ Earth image. The white pixel at the summit of Cleveland volcano identifies the location of the thermal anomaly. Courtesy John Bailey, AVO/UAFGI. AVO database image at URL: http://www.avo.alaska.edu/images/image.php?id=13328. 


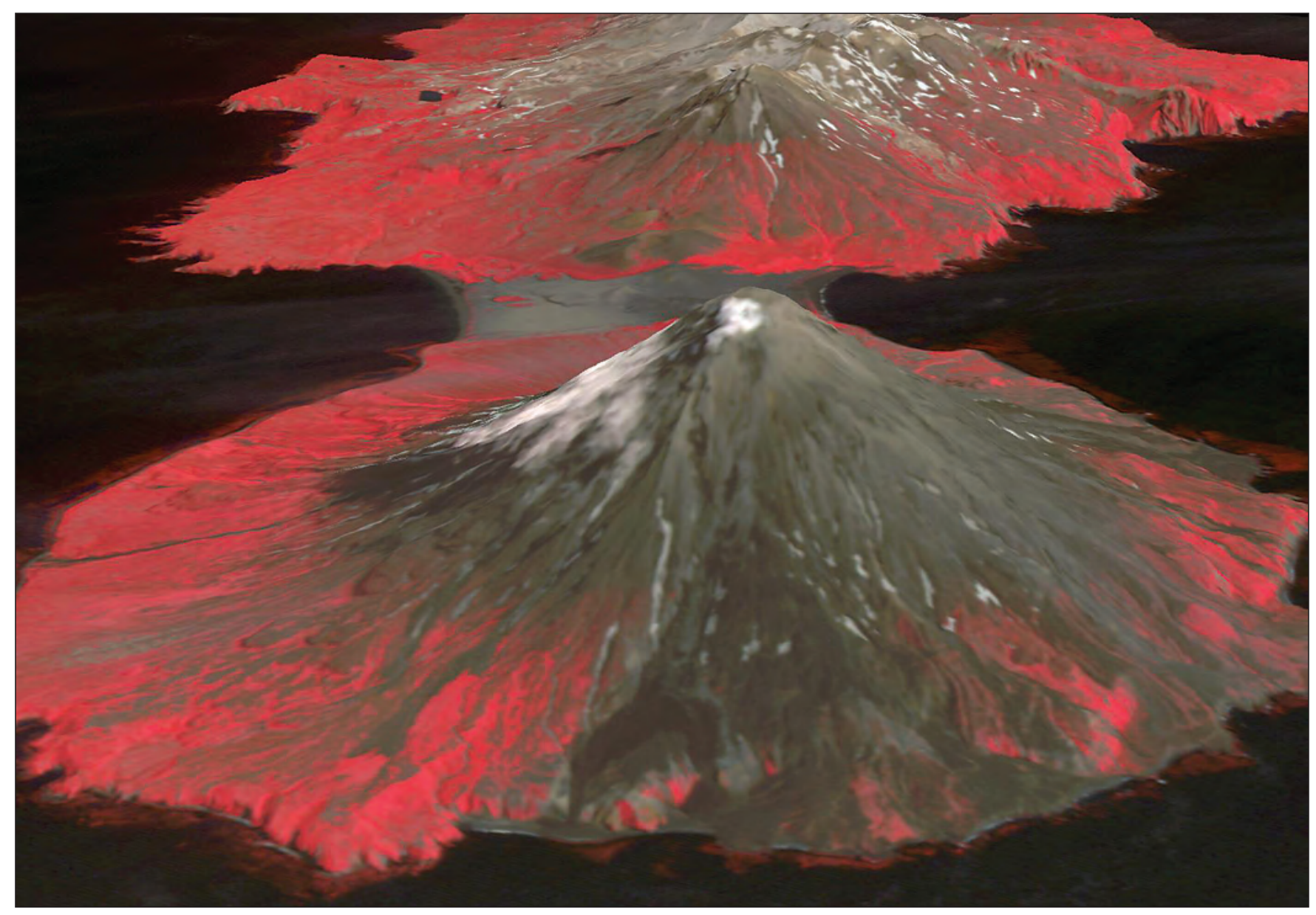

Figure 41. Oblique 3-D view of Cleveland volcano on July 20, 2007, using Advanced Spaceborne Thermal Emission and Reflection (ASTER) radiometer visible and near-infrared data draped over Shuttle Radar Topography Mission (SRTM) topography. This view from the west shows a small steam plume at the summit with darker debris flows that have run down the western flank. Image processed by Rick Wessels, AVO/USGS. Image data courtesy of NASA/GSFC/METI/ERSDAC/JAROS (National Aeronautics and Space Administration/Goddard Space Flight Center/ Ministry of Economy, Trade and Industry/Earth Remote Sensing Data Analysis Center/Japan Resources Observation System), and U.S./Japan ASTER Science Team. AVO database image at URL: http://www.avo. alaska.edu/images/image.php?id=13329. 


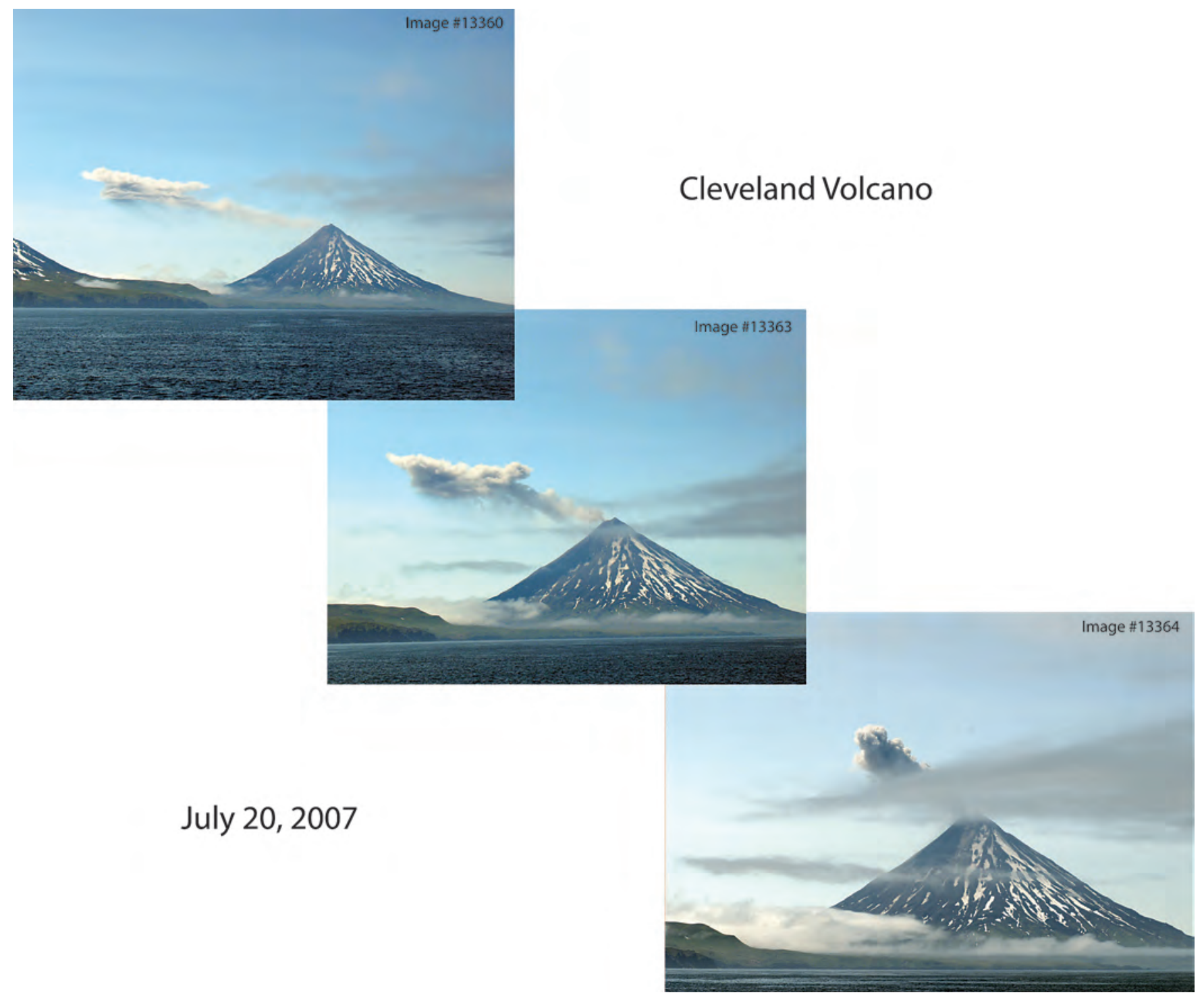

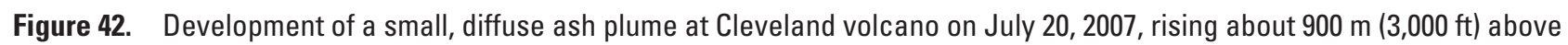
the summit and drifting to the south, characteristic of the eruptive activity during the summer of 2007. No ash emissions had been detected in satellite data since October 2006, most likely because of the low-level of emissions such as shown in these photographs. Photographs by Doug Dasher, Alaska Division of Environmental Conservation; and Max Hoberg, School of Fisheries, University of Alaska Fairbanks, aboard the U.S. Fish and Wildlife Service research vessel Norseman. View is from the northeast looking southwest. AVO database images 13360, 13363, 13364. AVO database image at URL: http://www.avo.alaska.edu/images/image.php?id=28292. 


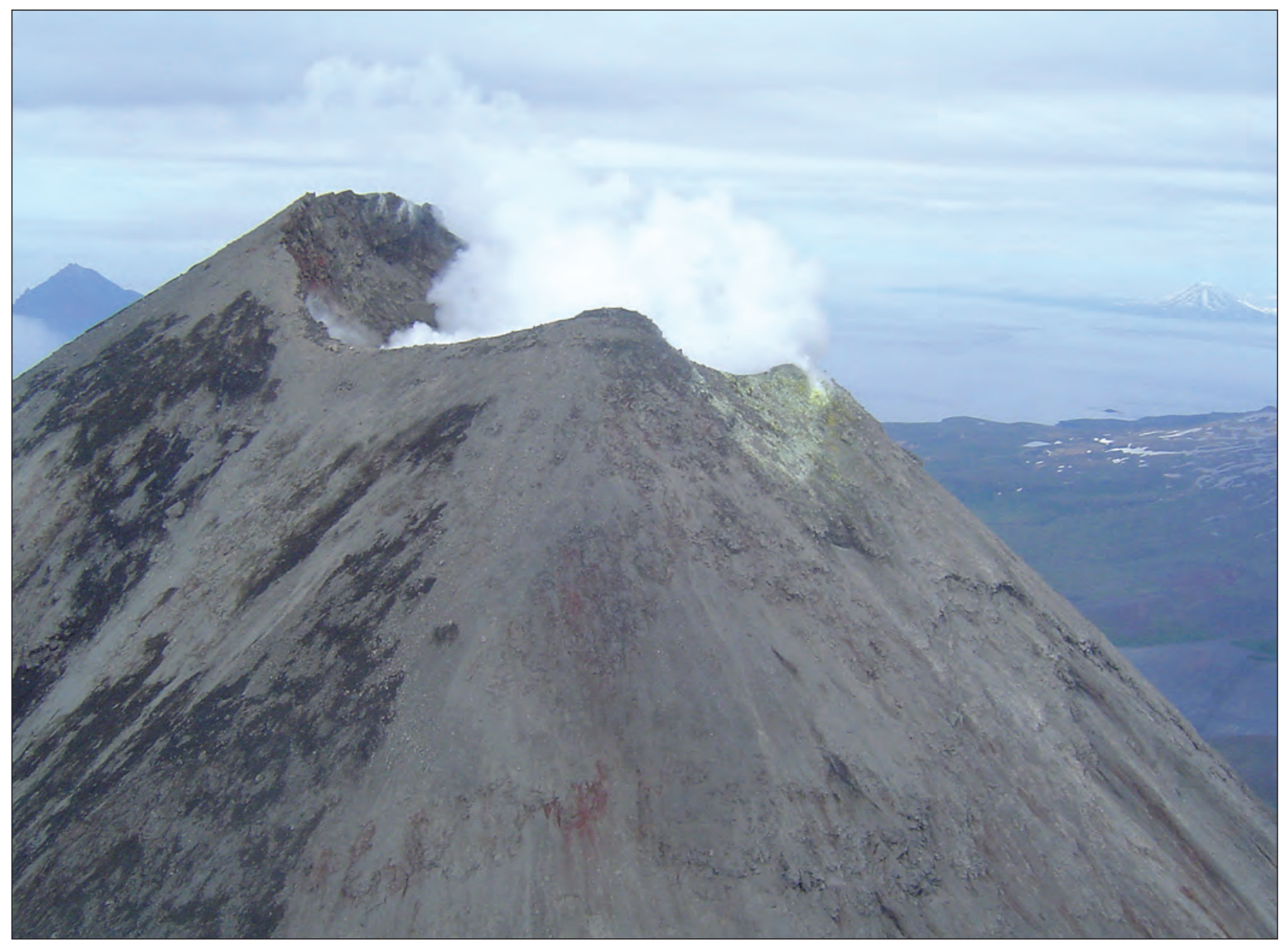

Figure 43. Oblique aerial view of the $2,730 \mathrm{~m}(5,676 \mathrm{ft})$ summit of Cleveland volcano on July 27,2007 . Water vapor and other gases billow from the steep-walled crater, approximately $150 \mathrm{~m}(490 \mathrm{ft})$ across. Prominent yellow-staining reflects precipitation of native sulfur from ongoing release of volcanic gas. Note the mantle of grey debris and blocks along the crater rim and upper slopes, probably produced during intermittent explosive activity at Cleveland over the previous few weeks. Two days before this photograph was taken, ASTER satellite data indicated temperatures as high as $359^{\circ} \mathrm{C}\left(678^{\circ} \mathrm{F}\right)$ in the summit region. Thermal anomalies had been seen intermittently by satellite since early February. Photograph by Andrew Rose, Maritime Helicopters. AVO database image at URL: http://www.avo.alaska.edu/images/image.php?id=13351. 


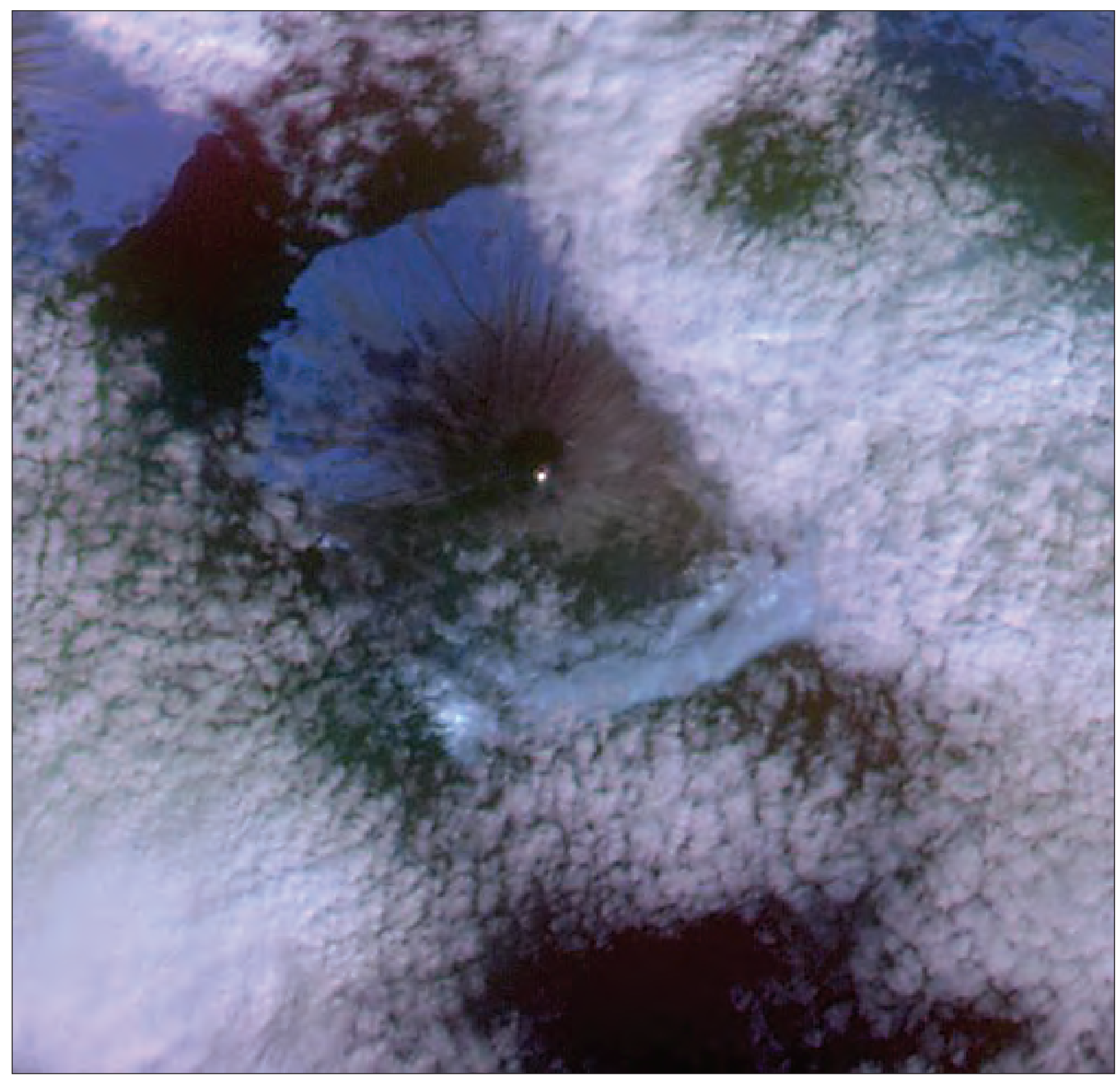

Figure 44. Cleveland ASTER data acquired September 13, 2007, at 22:29:38 UTC (02:29 AKDT). The image is partly cloudy, but shows a nice view of Cleveland's summit area. The thermal IR data show that the warmest part of the summit crater has a $90-\mathrm{m}$ pixel integrated brightness temperature of $18.4^{\circ} \mathrm{C}\left(65.1^{\circ} \mathrm{F}\right)$, a decrease from the $41^{\circ} \mathrm{C}\left(105.8^{\circ} \mathrm{F}\right)$ thermal anomaly observed on July 27, 2007. Courtesy Rick Wessels, AVO/USGS. AVO database image at URL: http://www.avo.alaska.edu/images/image.php?id=28772. 


\title{
Korovin Volcano (Atka)
}

\author{
CAVW\# 1101-16- \\ $52^{\circ} 23^{\prime} \mathrm{N} 174^{\circ} 10^{\prime} \mathrm{W}$ \\ $1,533 \mathrm{~m}(5,030 \mathrm{ft})$
}

Atka Island, west-central Aleutian Islands

SEISMIC SWARMS, CONTINUED FUMAROLIC ACTIVITY

Inflation rate decreases from that of previous summer

Korovin Volcano on Atka Island in the west-central Aleutians began 2007 in Aviation Color Code YELLOW and Volcano Alert Level ADVISORY following an upswing in activity during 2006 (Neal and others, 2008b). A relatively high level of background seismicity has been prevalent since the AVO network was installed in 2004, and a higher level of seismicity that began in 2006 continued into the first half of 2007 (figs. 45 and $\underline{46}$ ).

Reports of steam clouds on December 24, 2006, were followed on January 11, 2007, by a M3.5 earthquake at Korovin, which is considered quite large for volcano-generated seismicity. A swarm of likely associated events were recorded during the week; however, a M8.2 earthquake in the Kurile Islands on January 12 (AKST) also may have triggered seismicity at Korovin (see sections, "Wrangell volcano" and "Akutan volcano").

On January 23, a series of tremor bursts were recorded, and on January 24, AVO received photographs from an Atka Village resident of a steam column rising from Korovin's active crater (fig. 47). The observer reported similar steam columns rose up to about 1,000 ft (about $300 \mathrm{~m}$ ) above the volcano every 15 to 80 minutes. Satellite images from the previous week indicated that the intermittent lake in Korovin's active crater was not present. Previously, in late September or early October 2006, the lake disappeared following a strong episode of steam emission. The lake had not re-appeared as of mid-January 2007.

The next report of activity at Korovin came on the afternoon of February 14 when NWS contacted AVO to pass on a PIREP from a U.S. Coast Guard C-130 of a steam plume extending 5,000- 8,000 ft (about 1,500-2,400 m) over Korovin. A SIGMET was not issued.

A couple of weeks later, Atka Village residents Lynn and Kerry Moore sent photographs to AVO taken on March 3 of an ash deposit on the west flank of Korovin (fig. 48). Prior to taking the photographs, the Moores observed steam rising from the active, south summit vent. No anomalous activity was noted in AVO satellite reports for that day; however, a flurry of low frequency seismicity occurred that morning, comparable to seismicity of the last few months.
Phreatic activity at Korovin produced similar ash deposits in 2004 and 2006 (Neal and others, 2008b).

Episodes of tremor occurred over several days in May, June, and August, and a thermal anomaly was detected in satellite images in early August. Steam plumes were observed by residents in Atka Village in late July (fig. 49). The satellite-based Ozone Monitoring Instrument (OMI) detected a small $\mathrm{SO}_{2}$ cloud located about $300 \mathrm{~km}(186 \mathrm{mi})$ north of Cleveland volcano on August 5, 2007, that likely originated at Korovin based on wind dispersal models. An aerial photograph taken that day shows a steam plume wafting from the crater (fig. 50). On August 19, a flurry of 33 detected seismic events located $4 \mathrm{~km}$ (2.5 mi) southeast of Kliuchef was detected [see figures 50 and $\underline{52}$ for location of Kliuchef, $6.5 \mathrm{~km}$ (4 mi) south of Korovin]. This was followed on August 20 by a small emission of $\mathrm{SO}_{2}$ from Korovin that was detected by OMI (fig. 51).

Inflation beneath the northern part of Atka Island that began in June 2006 and totaled 9-10 cm (3.5-3.9 in.) of uplift, had begun to taper off in 2007 (Zhong Lu and Peter Cervelli, USGS, written commun., 2007). An InSar interferogram acquired July 1, 2007, shows a distinct but weakened anomaly still centered on the west flank of Kliuchef volcano (figs. 52 and $\underline{53}$ ). Seismicity over the same period appears to have tracked the uplift (P. Cervelli, USGS, written commun., 2007); compare the area of uplift with the located seismicity in figure 53.

The decreasing trends of seismicity and uplift prompted AVO to begin considering a status change for the volcano, which had been at Aviation Color Code YELLOW and Volcano Alert Level ADVISORY since November 6, 2006. On September 7, 2007, the Aviation Color Code/Volcano Alert Level was downgraded to GREEN/NORMAL. Although circuit problems plagued the Atka Island network on several occasions, activity at Korovin was uneventful for the remainder of 2007.

AVO tracked activity at Korovin using seismic and satellite data, and occasional pilot reports. Several times during the year, AVO staff contacted Atka residents by telephone or email to gather additional observations or clarify AVO reports. 


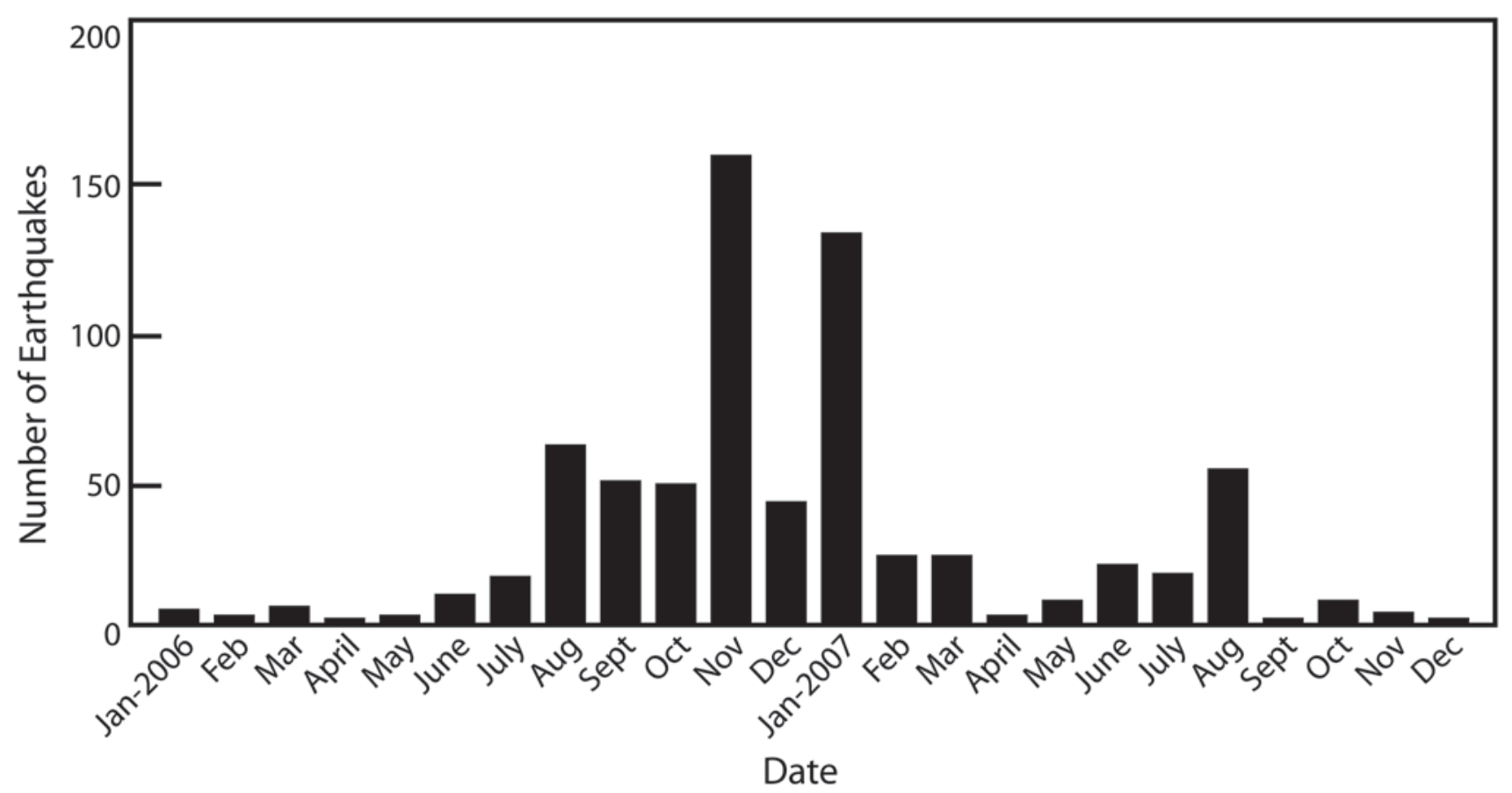

Figure 45. Number of monthly earthquakes for Korovin Volcano, 2006-07. Note the spike in activity that begins in about June 2006, peaks in November 2006 and January 2007, then diminishes during the summer of 2007. Courtesy Katrina Jacobs AVO/UAFGI.

Korovin Volcano is 1,533 m (5,030 ft) ASL. This stratovolcano is on the northern part of Atka Island, about $184 \mathrm{~km}(110 \mathrm{mi})$ east of Adak, $540 \mathrm{~km}$ (330 mi) west of Dutch Harbor, and 1,760 km (1,100 mi) southwest of Anchorage. Korovin has two distinct summit craters, about

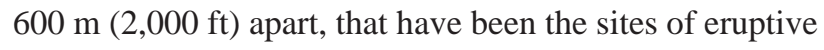
activity as recently as June 1998; reported heights of the ash plume produced by the 1998 eruption ranged from 4,900 to 9,200 m (16,000-30,000 ft) ASL (Neal and others, 2003). The most recently active of the craters hosts an intermittent, small, roiling lake that occasionally produces energetic steam emissions and deposits ash on the upper slope of the cone (Neal and others, 2008b). Thermal springs and fumaroles are on and near Korovin and nearby Kliuchef. Korovin has erupted several times historically; known or suspected events occurred in 1907, 1951, 1953-1954, 1973, 1976, 1986, 1987, and 1998 (AVO Website, 2005-). All known eruptions produced minor amounts of ash and one (1973) produced a small lava flow. Periods of increased seismicity, such as that which occurred in early 2006 appear to be common at Korovin, perhaps in response to its very active hydrothermal system (Motyka and others, 1993). Data are received intermittently from the 9-station seismic network on Korovin due mostly to circuit problems between Atka village and Anchorage. 
Korovin Volcano Seismicity 26-Jan-2007 - 21-Aug-2007
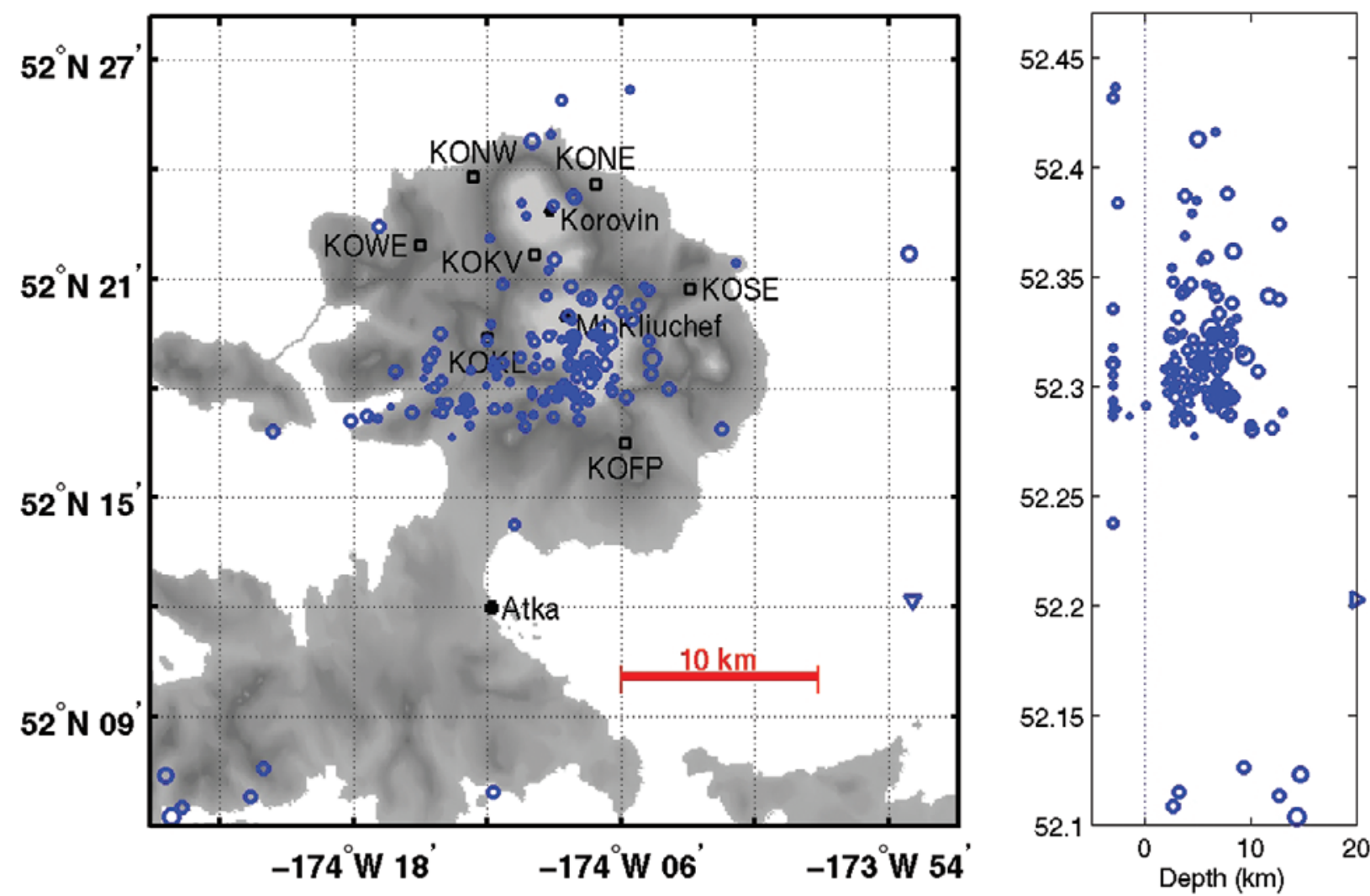

Mag. Symb. Size

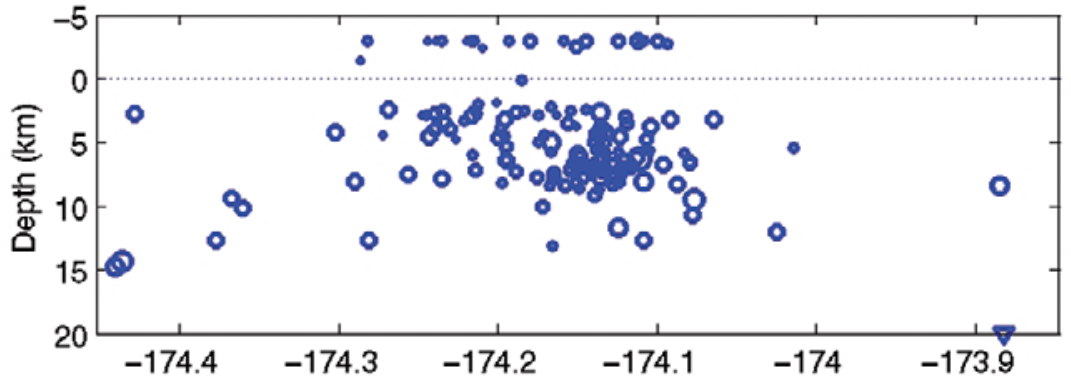

$\begin{array}{ll}0 & \\ 1 & \circ \\ 2 & 0 \\ 3 & 0 \\ 4 & 0 \\ 5 & 0\end{array}$

Total event \#: 144

Events/day: 1

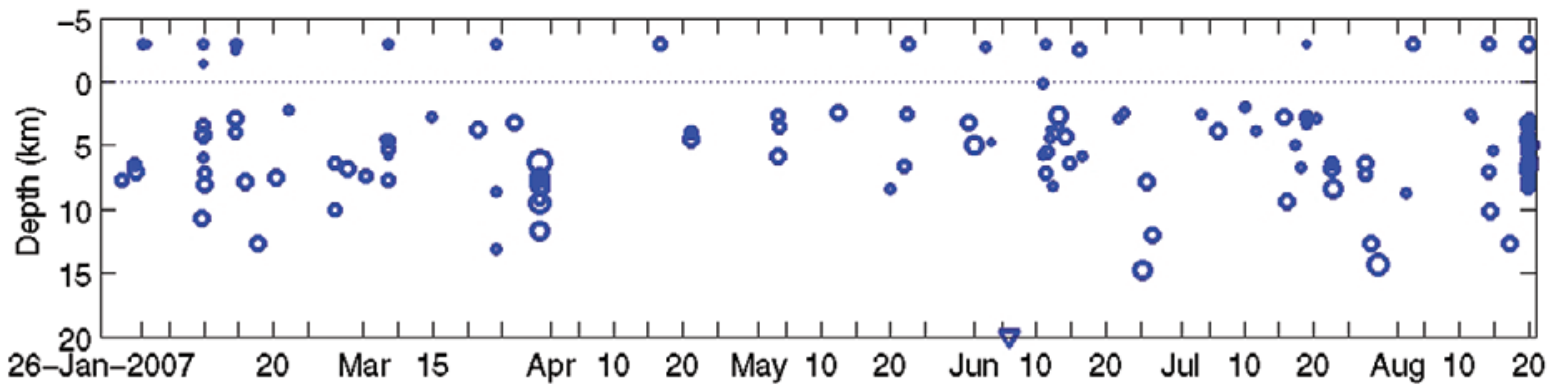

Figure 46. Seismicity at Korovin and Kliuchef Volcanoes on Atka Island from January 26, 2007, to August 21, 2007 (left), and cumulative seismicity from April 2005 to August 21, 2007. Seismicity was highest between June 2006 and March 2007. Although generally attributed to Korovin, the seismicity is actually mostly clustered beneath Kliuchef. All recent eruptive activity has originated from Korovin. Kliuchef is considered a satellite flank vent on the northern rim of Atka caldera. Graphs courtesy Steve McNutt, AVO/UAFGI. 


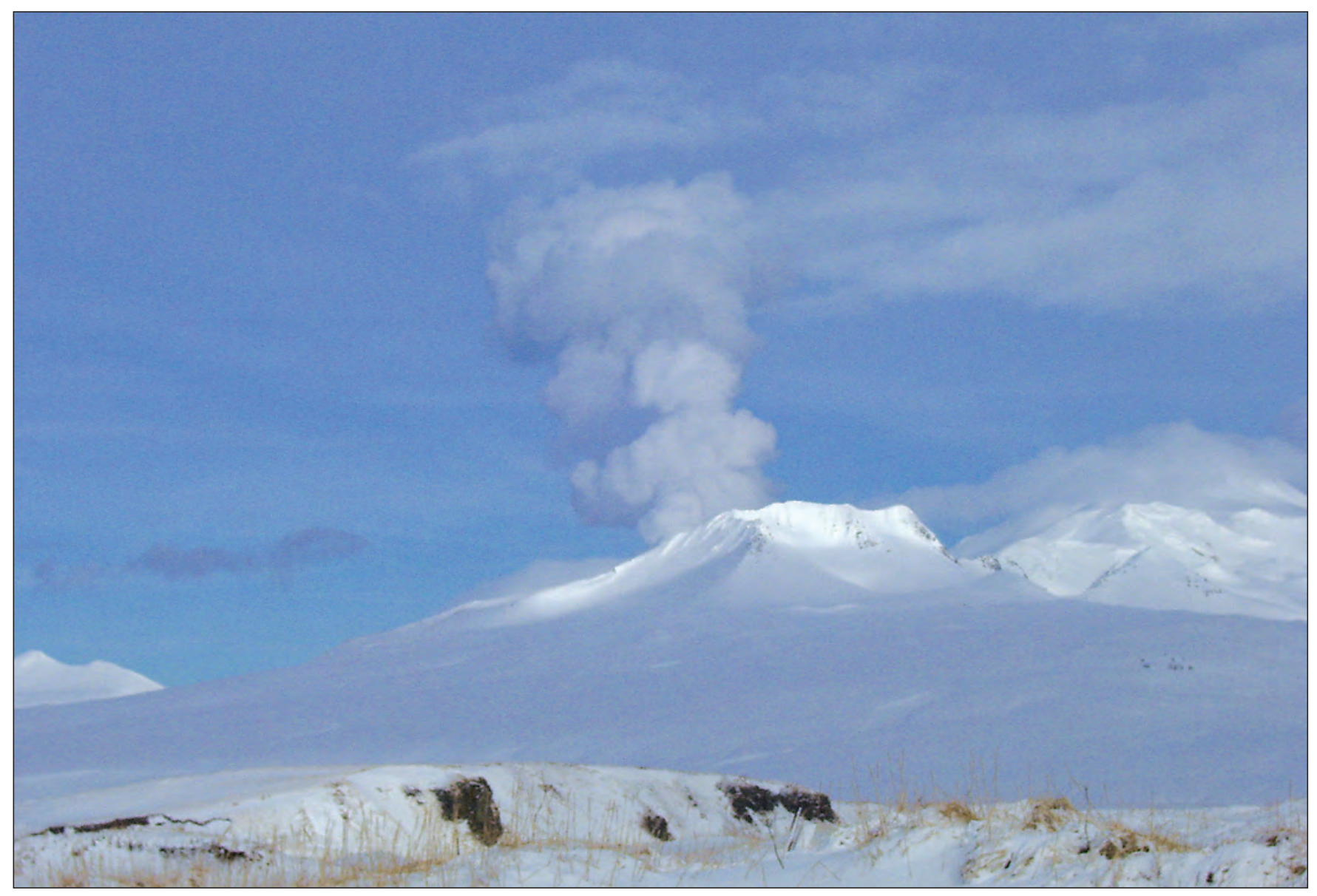

Figure 47. Large steam plume rising from Korovin Volcano on January 23, 2007. Similar to photographs taken in 2005 and 2006 (McGimsey and others, 2007; Neal and others, 2008b). View is from Atka Village. Photograph by Louis Nevzoroff, private citizen. AVO database image at URL: http://www.avo.alaska.edu/images/image.php?id=13135. 


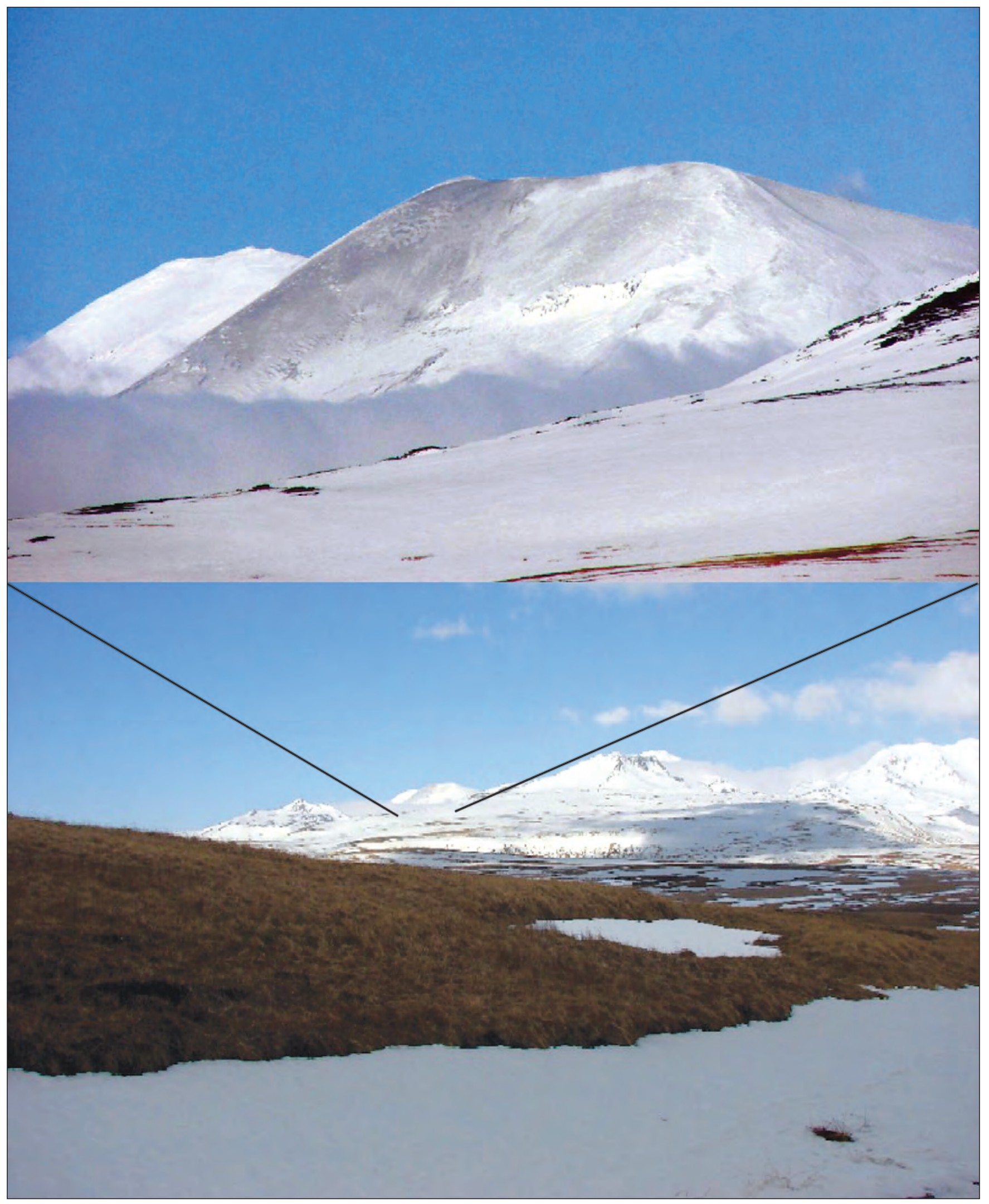

Figure 48. Ash on the west flank of Korovin Volcano, March 3, 2007. Top image is a close-up view of the area marked in bottom image for perspective. Both photographs by Kerry Moore, Atka Village, taken from about 0.5 mile $(0.8 \mathrm{~km})$ from Atka School along the road to the town dock. AV0 database images \#13170, top, \#13169, bottom. AV0 database image at URL: http://www.avo.alaska. edu/images/image.php?id=28302. 


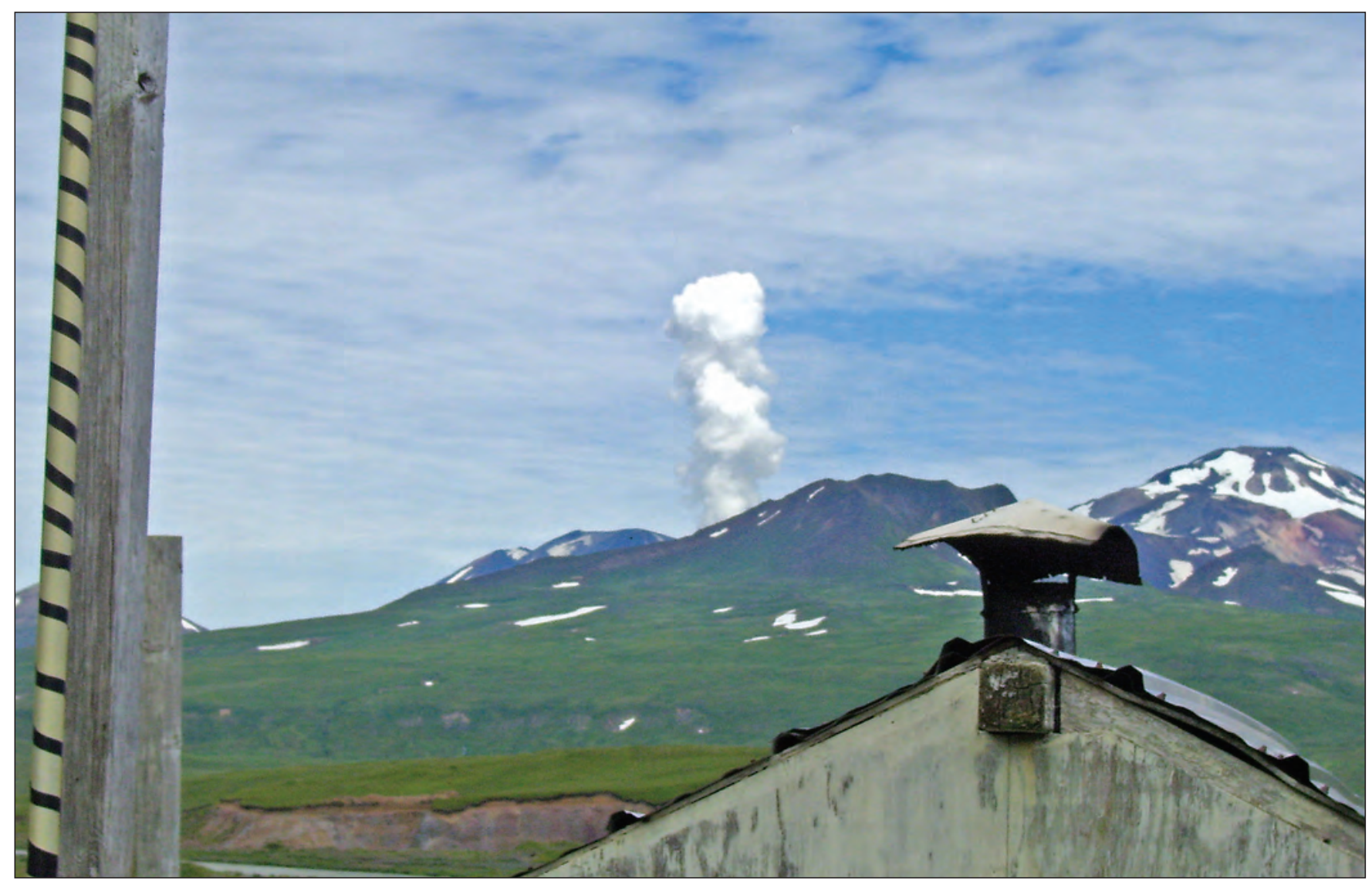

Figure 49. Steam column rising from Korovin Volcano on July 27, 2007 as seen from Atka Village. The steam was estimated to reach about 700 to 800 feet $(215-245 \mathrm{~m})$ above the crater rim. Photograph by Louis Nevzoroff, private citizen. AVO database image at URL: http://www.avo.alaska.edu/images/image.php?id=13333. 




Figure 50. Korovin Volcano as seen from 30,000 feet $(9.1 \mathrm{~km})$ ASL on August 5, 2007. Steam is wafting from the active crater. The partially obscured crater at top of image is Kliuchef Volcano. View is from the north. Photograph by Burke Mees, Alaska Airlines. AVO database image at URL: http://www.avo.alaska.edu/images/image.php?id=13399. 


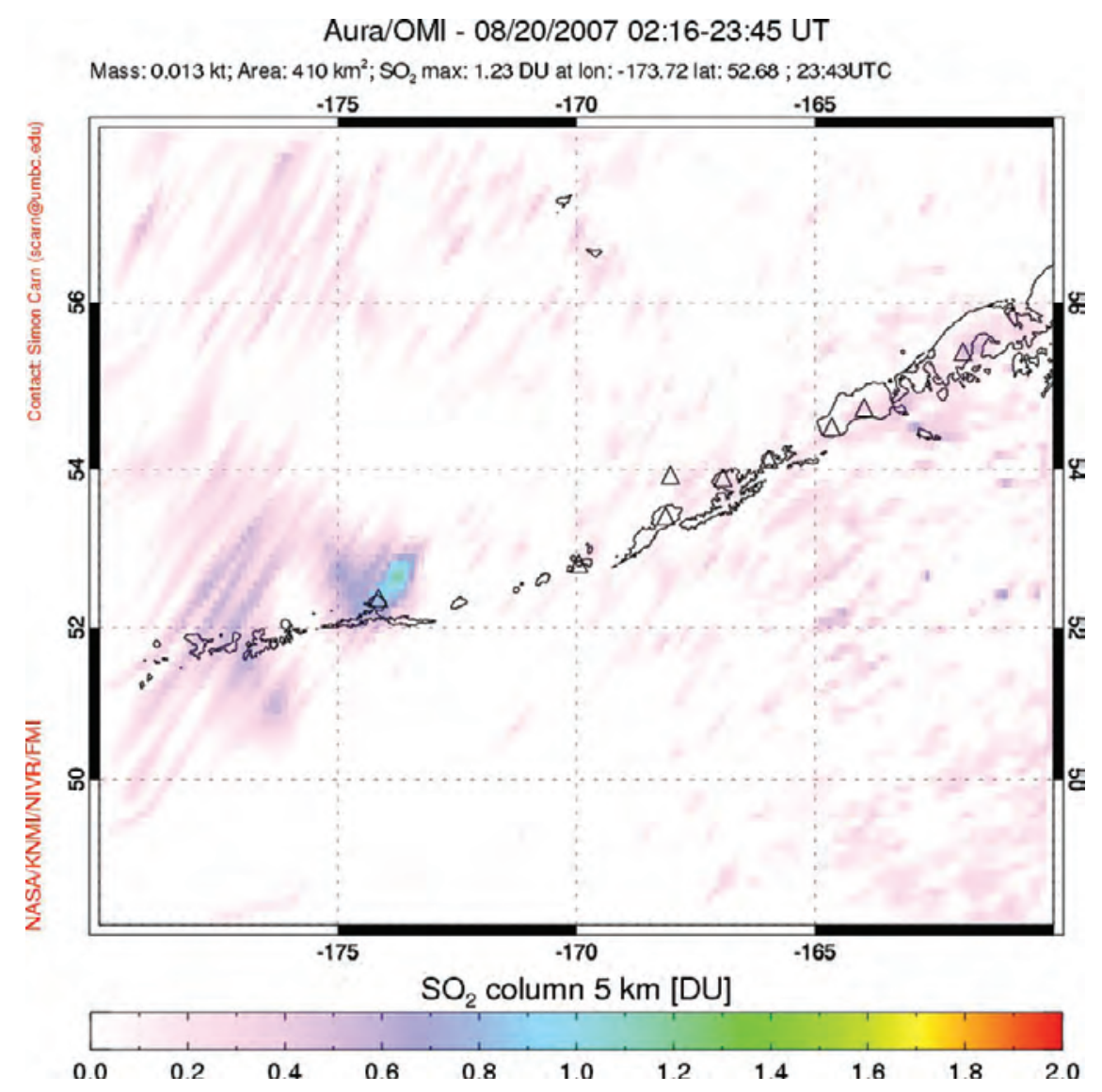

Figure 51. A several-pixel mass of $\mathrm{SO}_{2}$ immediately northeast of Korovin Volcano on Atka Island as measured by Ozone Monitoring Instrument (OMI) on August 20, 2007. Courtesy Dave Schneider, AVO/USGS. 


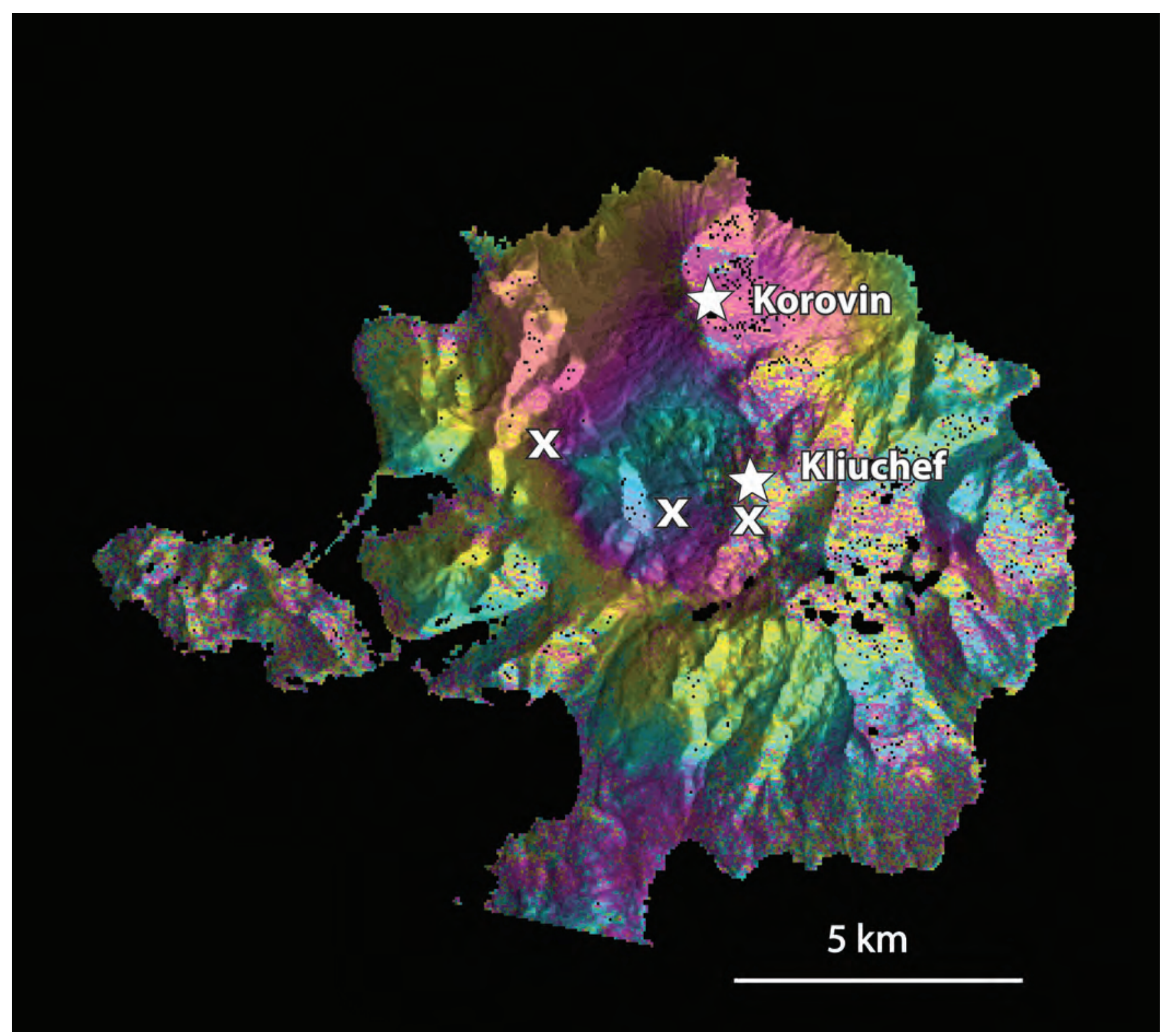

Figure 52. InSAR interferogram for the northern part of Atka Island acquired on July 1, 2007, showing the circular pattern of uplift centered on the west flank of Kliuchef. Seismicity over the same period appears to have tracked the uplift; compare uplift area to location of seismic cluster in figure 46. Although a total of 9-10 cm of uplift has occurred, the uplift rate in 2007 declined since first observed in July through October 2006 (Neal and others, 2008b). Summits of young volcanoes Korovin and Kliuchef marked with stars. Approximate position of known thermal areas shown with "X", adapted from Motyka and others (1993). Figure courtesy of Zhong Lu, USGS. 


\section{0/29/2006-08/05/2007}

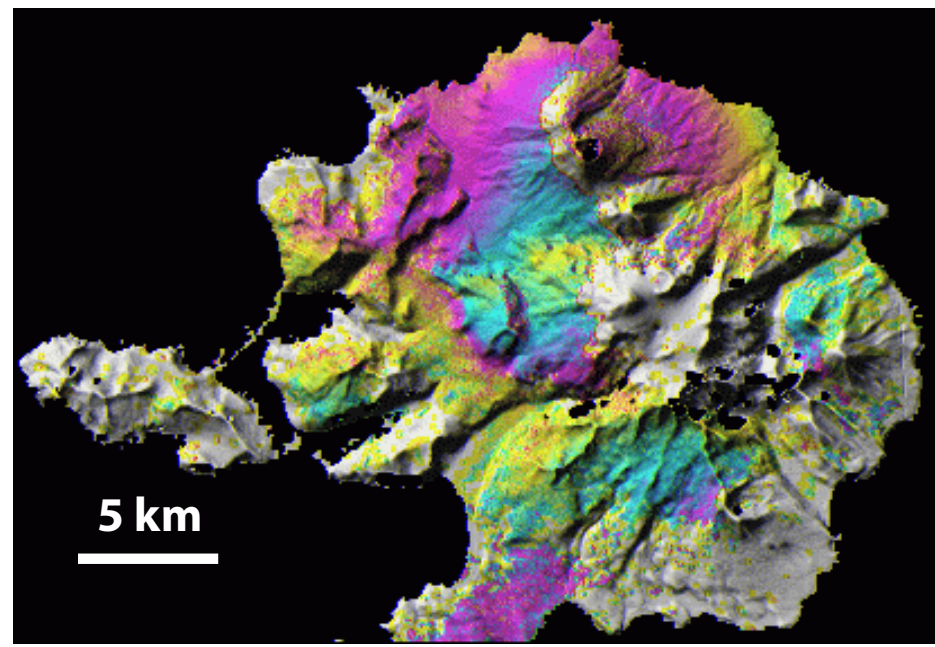

06/12-07/17/2007

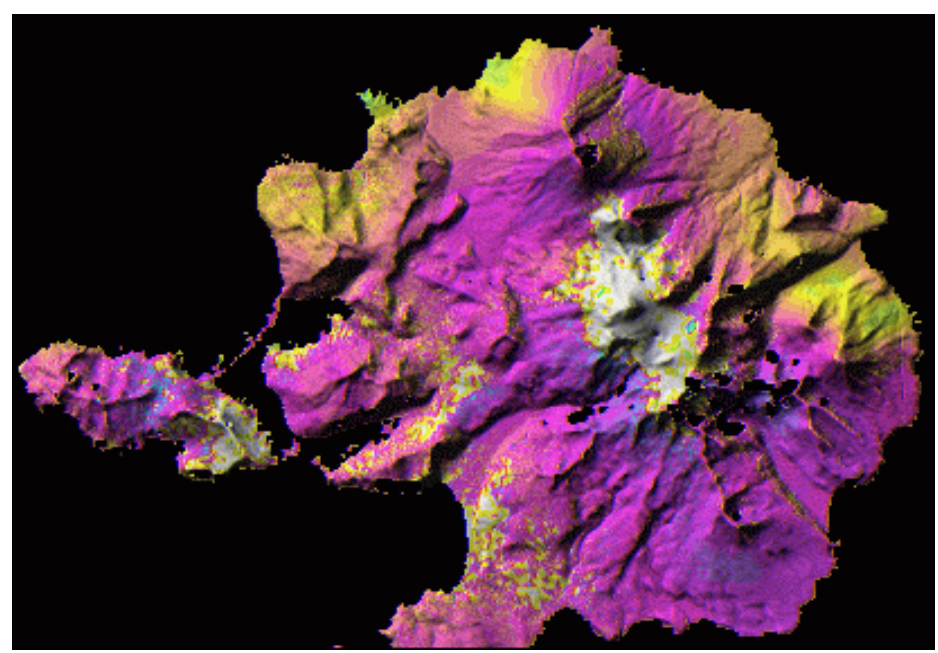

$06 / 20-07 / 25 / 2007$

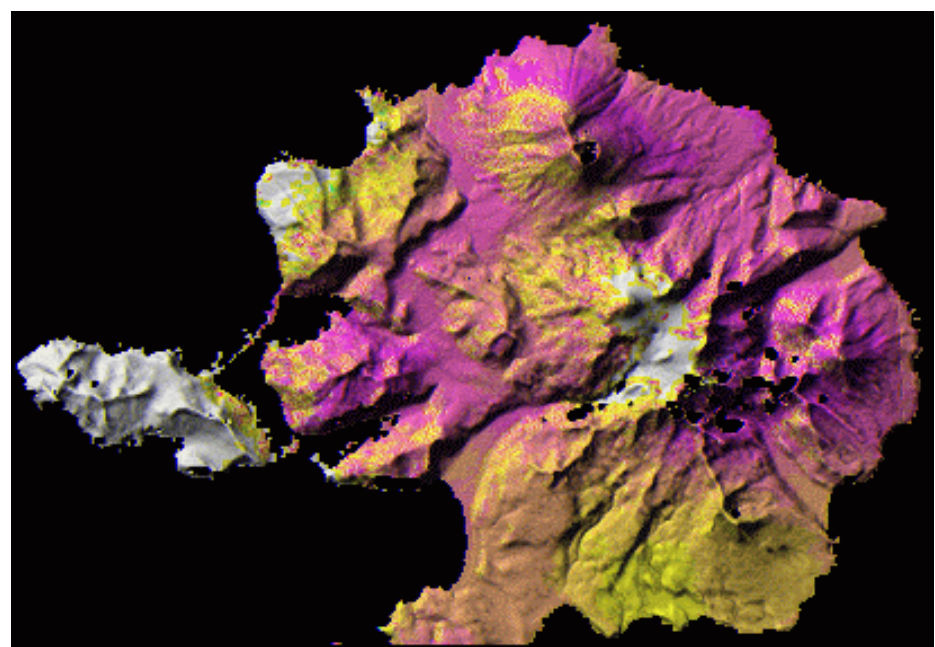

\section{Range Change}

$\mathbf{0}$ $2.83 \mathrm{~cm}$

Figure 53. InSAR interferograms that span from 35 days to about 1 year from October 2006 to August 2007. Deformation after October 2006 is significantly less than that of June-0ctober 2006. InSAR deformation phase values are draped over a shaded relief map derived from SRTM DEM data. Each fringe (full color cycle) represents $2.8 \mathrm{~cm}$ of range change between the ground the satellite. Areas that lack interferometric coherence are uncolored. Figure courtesy of Zhong Lu, USGS. 


\section{Miscellaneous Observations and Activity}

New (?) KLAWASI MUD VENT: Local residents in the Copper River Valley reported unusual upwellings near the Klawasi mud volcanoes in late March 2006 (Neal and others, 2008b). During the summer of 2007, aerial reconnaisance by local pilots found no evidence of mud or water flows in the area, and the prospect of a new mud vent was deemed unlikely. The nature of the 2006 activity remains unknown.

\section{Volcanic Activity, Kamchatka Peninsula, and the Northern Kurile Islands, Russia}

More than 60 potentially active volcanoes on Russia’s Kamchatka Peninsula and Kurile Islands pose a serious threat to aircraft in the North Pacific, especially for planes on the North Pacific, Russian Trans-East, and Cross-Polar routes (Kirianov and others, 2002; Neal and others, 2008a; Neal and others, 2009). The primary responsibility for monitoring and alerting the aviation community to activity in Russia lies with the Kamchatka Volcanic Eruptions Response Team (KVERT) for Kamchatka and the northern Kuriles, and the Sakhalin Volcanic Eruption Response Team (SVERT) for the remaining Kuriles (see section, "Volcanic Activity, Central and Southern Kurile Islands”).

KVERT is a cooperative program consisting of scientists from the Institute of Volcanology and Seismology (IVS), Kamchatka Branch of Geophysical Survey (KBGS), and AVO. The KBGS component of KVERT monitors 11 of the most frequently active volcanoes in Kamchatka and on Atlasova Island in the north Kuriles with one or more short-period seismometers (ig. 54; table 6). KVERT staff analyze AVHRR and MODIS satellite data daily. In addition, they receive reports of volcanic activity from scientific observers in the communities of Severo-Kurilsk on Paramushir, Klyuchi, and Kozyrevsk (fig. 54). Near real-time, Web-camera images of Sheveluch, Klyuchevskoy, and Bezymianny Volcanoes also are part of the routine monitoring. KVERT also receives occasional reports from scientific field parties near Karymsky Volcano, and pilot reports are relayed to KVERT from the local Civil Aviation Meteorological Center at Yelizovo Airport. AVO conducts satellite monitoring of portions of the Russian volcanic arcs and facilitates dissemination of hazard information for eruptions from the Kuriles and Kamchatka. AVO shares twice-daily satellite monitoring reports with KVERT staff via email. type.

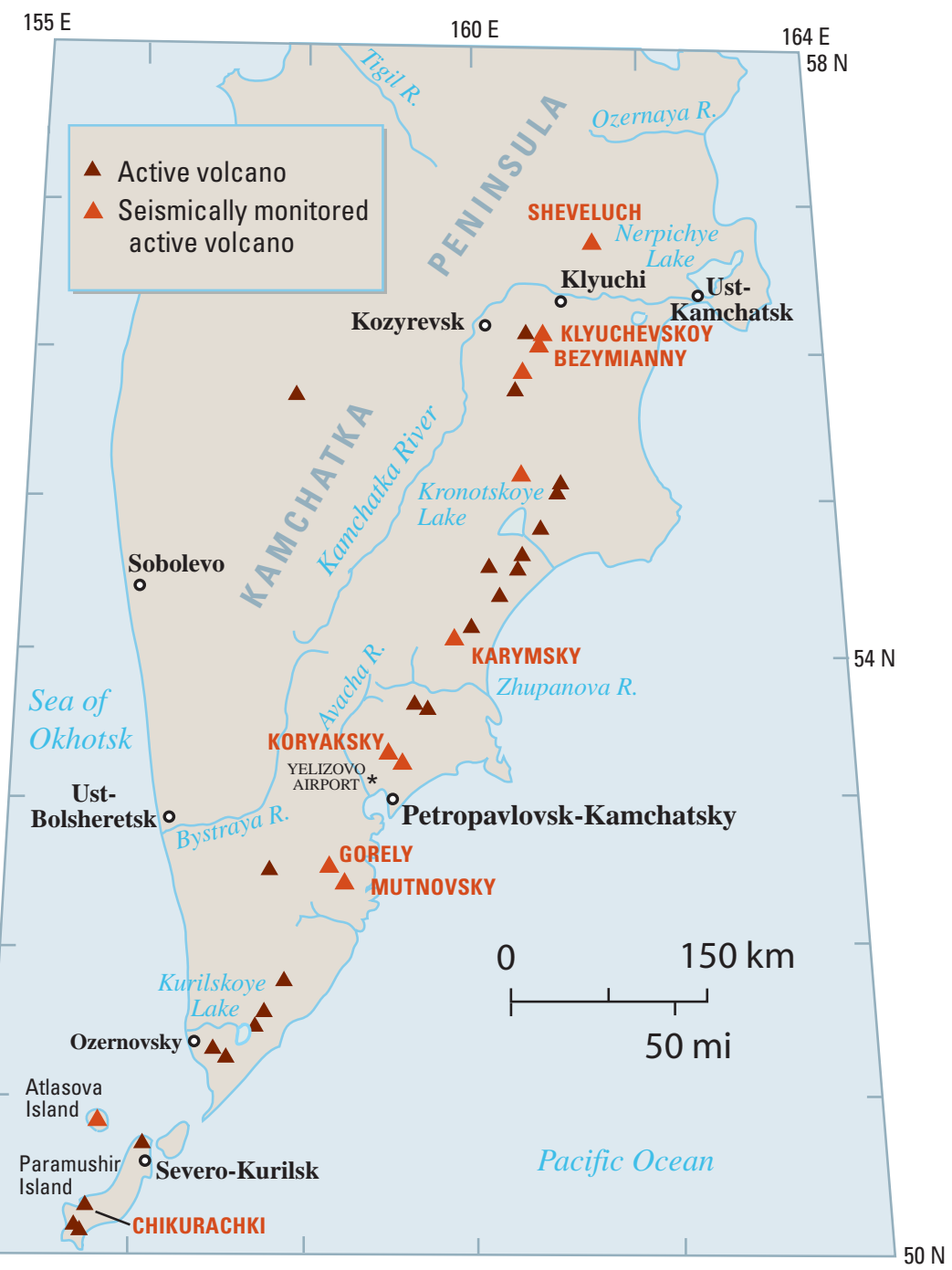

Figure 54. Kamchatka Peninsula and the northern Kurile Islands of Alaid and Paramushir. Volcanoes discussed in this report are labeled with bold red

KVERT operations were disrupted for the month of March as funding from the Russian aviation authority was temporarily halted. Informally, KVERT continued to send important activity notifications via email to AVO. On behalf of KVERT, AVO issued Information Releases to describe ongoing Kamchatkan volcanic activity (Neal and others, 2008a.)

In 2007, six volcanoes in Kamchatka and one on the north Kurile island of Paramushir were active requiring some level of AVO response. Summaries of this activity and related color code changes for Russian volcanoes are listed in tables 7 and $\underline{8}$.

The following summaries of activity contain reported events according to Kamchatkan local dates and Coordinated Universal Time (UTC), which equals AKDT + 8 hours and AKST+ 9 hours. The equivalent local Kamchatkan time is 21 hours ahead of Alaska. This compilation is derived from a number of sources including KVERT weekly updates, unpublished AVO internal files and documentation, Global Volcanism Program Volcanic Activity reports, and other information available at URL: http://www. volcano.si.edu/reports/index.cfm. 
Table 6. Seismically monitored volcanoes of Kamchatka and Atlasova Island as of December 2007.

[Compiled by S. Senyukov, Kamchatka Branch of Geophysical Surveys (KBGS), and C. Neal, Alaska Volcano Observatory. Prior to 1979, other Russian scientific institutes maintained programs of volcano monitoring in Kamchatka (a partial listing includes: 1961-1971, Pacific Seismological Department of Institute of Earth Physics; 1972-1978 - Institute of Volcanology)]

\begin{tabular}{|c|c|c|}
\hline Volcano & $\begin{array}{l}\text { Approximate start date of continuous seismic } \\
\text { monitoring by KEMSD (now KBGS) }\end{array}$ & Other monitoring techniques used routinely \\
\hline \multirow[t]{4}{*}{ Sheveluch } & Seismic station - February 1987 & \multirow{4}{*}{$\begin{array}{l}\text { Near real-time video system (2002); direct observation from } \\
\text { nearby Klyuchi; satellite imagery. }\end{array}$} \\
\hline & Telemetered data - 1980 & \\
\hline & Digital format - September 1996 & \\
\hline & Near-real time processing - 1999 & \\
\hline \multirow{4}{*}{ Klyuchevskoy } & Seismic station - 1961 & \multirow{4}{*}{$\begin{array}{l}\text { Near real-time video system (2000); direct observation from } \\
\text { nearby Klyuchi and Kozyrevsk; satellite imagery. }\end{array}$} \\
\hline & Telemetered data - 1987 & \\
\hline & Digital format - September 1996 & \\
\hline & Near-real time processing - 1999 & \\
\hline \multirow[t]{4}{*}{ Bezymianny } & Seismic station - 1961 & \multirow{4}{*}{$\begin{array}{l}\text { Near real-time video system (2003); Direct observation from } \\
\text { nearby Kozyrevsk; satellite imagery. }\end{array}$} \\
\hline & Telemetered data - October 1988 & \\
\hline & Digital format - September 1996 & \\
\hline & Near-real time processing - 1999 & \\
\hline \multirow[t]{4}{*}{ Plosky Tolbachik } & Seismic station - January 1977 & \multirow[t]{4}{*}{ Direct observation from nearby Kozyrevsk; satellite imagery. } \\
\hline & Telemetered data - November 1990 & \\
\hline & Digital format - September 1996 & \\
\hline & Near-real time processing - 1999 & \\
\hline \multirow[t]{4}{*}{ Kizimen } & Seismic station - July 2003 & \multirow[t]{4}{*}{ Satellite imagery. } \\
\hline & Telemetered data - July 2003 & \\
\hline & Digital format - July 2003 & \\
\hline & Near-real time processing - July 2003 & \\
\hline \multirow[t]{3}{*}{ Karymsky } & Telemetered data - September 1989 & \multirow[t]{3}{*}{ Field observation; satellite imagery. } \\
\hline & Digital format - January 1996 & \\
\hline & Near-real time processing - 1996 & \\
\hline \multirow[t]{4}{*}{ Koryaksky } & Seismic station - April 1963 & \multirow[t]{4}{*}{ Direct observation from PK; satellite imagery. } \\
\hline & Telemetered data - 1975 & \\
\hline & Digital format - January 1996 & \\
\hline & Near-real time processing - 1996 & \\
\hline \multirow[t]{4}{*}{ Avachinsky } & Seismic station - April 1963 & \multirow[t]{4}{*}{ Direct observation from PK; satellite imagery. } \\
\hline & Telemetered data - July 1976 & \\
\hline & Digital format - January 1996 & \\
\hline & Near-real time processing - 1997 & \\
\hline \multirow[t]{3}{*}{ Gorely } & Telemetered data - July 1980 & \multirow[t]{3}{*}{ Direct observation from PK; satellite imagery. } \\
\hline & Digital format - January 1996 & \\
\hline & Near-real time processing - 1996 & \\
\hline \multirow[t]{3}{*}{ Mutnovsky } & Telemetered data - July 1980 & \multirow[t]{3}{*}{ Direct observation from PK; satellite imagery } \\
\hline & Digital format - January 1996 & \\
\hline & Near-real time processing - 1996 & \\
\hline \multirow[t]{3}{*}{ Alaid } & Telemetered data - August 2001 & \multirow[t]{3}{*}{ Satellite imagery } \\
\hline & Digital format - August 2001 & \\
\hline & Near-real time processing - August 2001 & \\
\hline
\end{tabular}


Table 7. Summary of VOLCANIC ACTIVITY on Kamchatka Peninsula and in the Kurile Islands, Russia, 2007.

[Location of volcanoes shown in figure 1]

\begin{tabular}{|c|c|c|}
\hline Volcano & Date of activity & Type of activity \\
\hline Sheveluch & $\begin{array}{l}\text { Intermittently throughout the year; } \\
\text { significant pulse of activity in mid- } \\
\text { December. }\end{array}$ & $\begin{array}{l}\text { Lava dome growth, short-lived, explosive episodes, pyroclastic flows, } \\
\text { ash clouds, localized ash fall. }\end{array}$ \\
\hline Klyuchevskoy & $\begin{array}{l}\text { Several periods of increased activity } \\
\text { throughout the year; significant periods } \\
\text { of elevated eruption in May and June. }\end{array}$ & $\begin{array}{l}\text { Strombolian lava fountaining, lava flows, lahars, phreatic explosions, } \\
\text { Vulcanian blasts from the summit crater. }\end{array}$ \\
\hline Karymsky & Intermittently throughout the year & $\begin{array}{l}\text { Periods of increased seismicity continuation of low-level Vulcanian and } \\
\text { Strombolian explosions, lava flows, avalanches, degassing. }\end{array}$ \\
\hline Gorely/Mutnovsky & April and late December. & $\begin{array}{l}\text { Increased fumarolic activity at Gorely and an increase in seismicity. } \\
\text { Phreatic explosion at Mutnovsky recognized in hindsight. }\end{array}$ \\
\hline
\end{tabular}

Table 8. Level of Concern Color Code changes for Kamchatkan volcanoes in 2007.

[Description of Level of Concern Color Codes is shown in appendix 2. Dates are from the KVERT Information Release and reflect the date in Kamchatka]

\begin{tabular}{|c|c|}
\hline Color Code & Date of change \\
\hline \multicolumn{2}{|r|}{ SHEVELUCH } \\
\hline ORANGE & January 1 - December 19 \\
\hline RED & December 19 - December 20 \\
\hline ORANGE & December 20 - December 31 \\
\hline \multicolumn{2}{|r|}{ KLYUCHEVSKOY } \\
\hline YELLOW & January 1 - February 15 \\
\hline ORANGE & February 15 - May 17 \\
\hline RED & May 17 - June 1 \\
\hline ORANGE & June 1 - June 20 \\
\hline RED & June 20 - June 25 \\
\hline ORANGE & June 25 - June 28 \\
\hline RED & June 28 - July 4 \\
\hline ORANGE & July 4 - July 20 \\
\hline YELLOW & July 20 - August 17 \\
\hline GREEN & August 17 - December 31 \\
\hline \multicolumn{2}{|r|}{ BEZYMIANNY } \\
\hline YELLOW & January 1 - May 11 \\
\hline ORANGE & May 11 - May 17 \\
\hline YELLOW & May 17 - October 14 \\
\hline RED & October 14 - October 16 \\
\hline ORANGE & October 16 - October 20 \\
\hline YELLOW & October 20 - November 10 \\
\hline ORANGE & November 10 - November 22 \\
\hline YELLOW & November 22 - December 31 \\
\hline
\end{tabular}

\begin{tabular}{|c|c|}
\hline Color Code & Date of change \\
\hline \multicolumn{2}{|r|}{ KARYMSKY } \\
\hline ORANGE & January 1 - June 7 \\
\hline YELLOW & June 7 - June 8 \\
\hline ORANGE & June 8 - December 6 \\
\hline YELLOW & December 6 - December 31 \\
\hline \multicolumn{2}{|r|}{ GORELY } \\
\hline GREEN & January 1 - December 24 \\
\hline YELLOW & December 24 - December 31 \\
\hline \multicolumn{2}{|r|}{ MUTNOVSKY } \\
\hline GREEN & January 1 - December 2 \\
\hline YELLOW & December 2 - December 31 \\
\hline \multicolumn{2}{|r|}{ CHIKURACHKI } \\
\hline NOT ASSIGNED & January 1 - April 10 \\
\hline ORANGE & April 10 - April 27 \\
\hline YELLOW & April 27 - May 11 \\
\hline GREEN & May 11 - August 19 \\
\hline ORANGE & August 19 - November 15 \\
\hline YELLOW & November 15 - November 22 \\
\hline GREEN & November 22 - December 31 \\
\hline
\end{tabular}




\author{
Sheveluch Volcano \\ CAVW\# 1000-27- \\ $56^{\circ} 38^{\prime} \mathrm{N} 161^{\circ} 21^{\prime} \mathrm{W}$ \\ $3,283 \mathrm{~m}(10,771 \mathrm{ft})$ \\ 2,500 m (8,200 ft) - approximate elevation of lava dome summit \\ Kamchatka Peninsula \\ LAVA DOME GROWTH CONTINUES \\ Frequent ash plumes, pyroclastic avalanches
}

In 2007, lava-dome growth continued, accompanied by frequent explosive ash plumes and hot pyroclastic avalanches off the unstable lava dome. The volcano began the year at Level of Concern Color Code ORANGE and weekly observational summaries reported occasional ash plumes as high as $12 \mathrm{~km}(37,000 \mathrm{ft})$ trailing 10-400 km (6-250 mi) usually east or northwest from the volcano. During periods of quiescence, a fumarolic plume rising several kilometers above the active dome was common (fig. 55) and satellite imagery detected strong thermal anomalies over the active lava dome fairly consistently. Seismicity remained above background the entire year with hundreds of earthquakes recorded on many days.

On March 29, a significant but short-lived explosive event occurred at Sheveluch producing an ash cloud in excess of $9.8 \mathrm{~km}(32,000 \mathrm{ft})$ ASL. Sixteen hours later, a second, 6-minute long explosion sent ash possibly as high as $12 \mathrm{~km}$ (40,000 ft) ASL, although visual estimates by KBGS and satellite determined heights by AVO placed the cloud at $10 \mathrm{~km}$ (33,000 ft) ASL. No color code change occurred due to the interruption in KVERT operations. Information about these explosions was relayed by email between AVO and KBGS staff; Volcanic Ash Advisories (VAA) were issued by Tokyo Volcanic Ash Advisory Center (VAAC), and Significant Meteorological Information (SIGMETs) were issued by Yelizovo Meteorological Watch Office (MWO), and telephone notification to U.S. agencies by AVO.
In mid-August, observers in Klyuchi noted strong incandescence and increased apparent vigor of dome growth. Accompanying this were several pyroclastic avalanches and ash plumes reaching $4.5 \mathrm{~km}(14,800 \mathrm{ft})$ ASL. In mid-November, observers on an over flight of the volcano documented a new lava flow lobe on the southwestern sector of the active lava dome. On December 18, KVERT reported an increase in seismicity at Sheveluch; this was followed by two strong explosive events sending ash to 6.5 and $8.7 \mathrm{~km}$ (21,300 and 28,500 ft) ASL. KVERT elevated the Level of Concern Color Code to RED briefly during this period of heightened activity.

Sheveluch Volcano is the northernmost active volcano in Kamchatka. It is one of the largest and most active in the region with at least 60 large eruptions during the Holocene (Bogoyavlenskaya and others, 1985; Ponomareva and others, 1998, 2008). Historical eruptive activity has been characterized by lava-dome growth and explosive collapse, often accompanied by large debris avalanches. A catastrophic flank collapse event in 1964 formed the modern amphitheater within which the active lava dome is now growing (Zharinov and others, 1995). The ongoing phase of lava-dome growth and explosive activity began in late August 1980 and continues into 2010. 


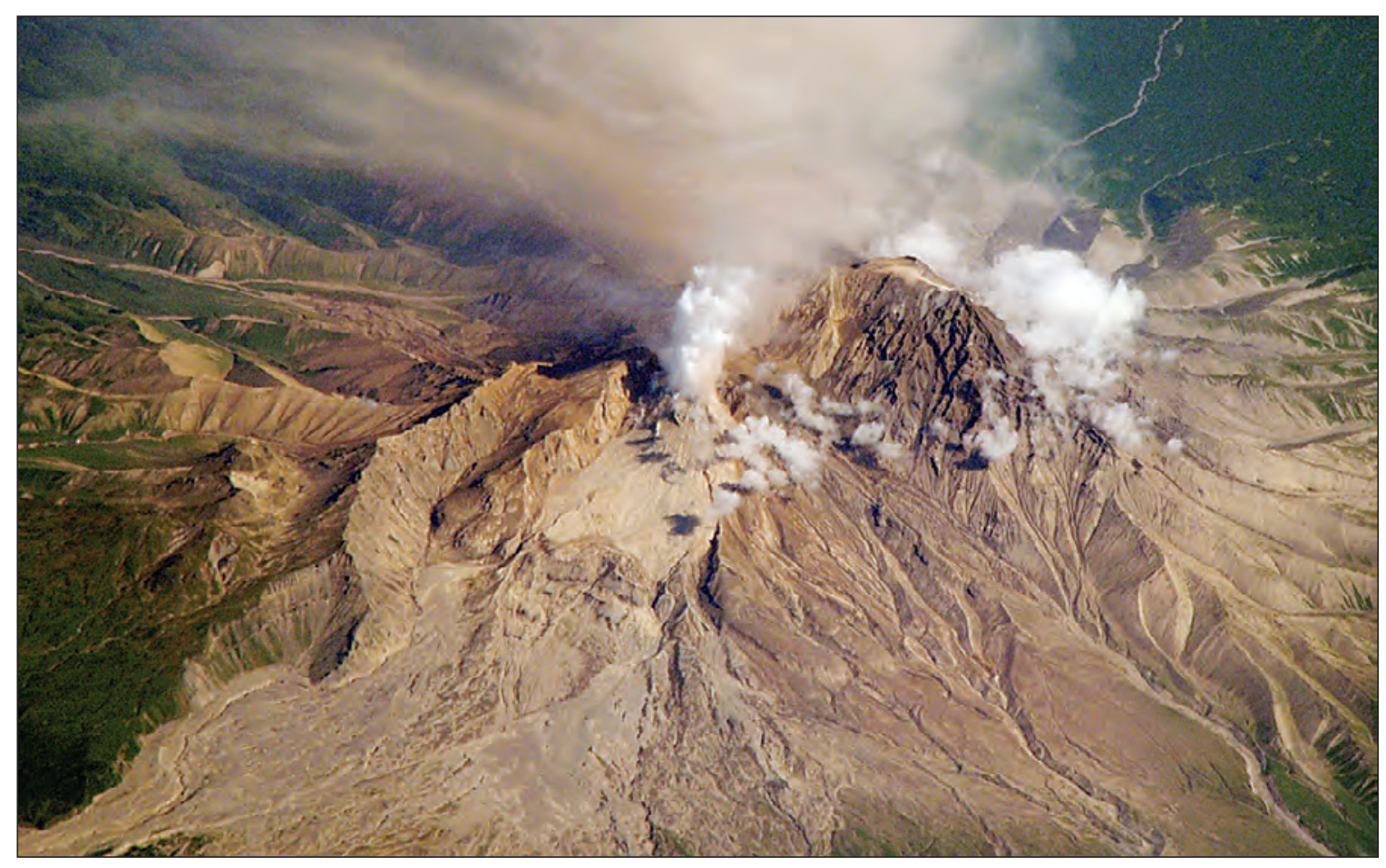

Figure 55. View of Sheveluch Volcano from the International Space Station, July 10, 2007. At the center of the image is the active lava dome surrounded on the southeast by light-colored fresh pyroclastic avalanche deposits. A tan, hazy ash cloud drifts to the north over forested terrain. A white fumarolic plume rises above the dome. Image ISS015, Roll E, Frame 11913 taken on July 10, 2007. Courtesy of the Image Science and Analysis Laboratory, NASA Johnson Space Center, URL: http://eol.jsc.nasa.gov. 


\title{
Klyuchevskoy Volcano
}

\author{
CAVW\# 1000-26- \\ $56^{\circ} 03^{\prime} \mathrm{N} 160^{\circ} 38^{\prime} \mathrm{W}$ \\ $4,750 \mathrm{~m}(15,585 \mathrm{ft})$
}

Kamchatka Peninsula, Russia

PERIODS OF INCREASED EXPOLSIVITY AND LAVA FLOW PRODUCTION

Ash falls on nearby communities, lahara

Klyuchevskoy began the year at Level of Concern Color Code YELLOW with seismicity slightly elevated above background (several tens to several hundred earthquakes per day and occasional tremor were recorded on KBGS seismometers) and a weak fumarolic plume emanating from the summit crater. The thermal anomaly seen in satellite images beginning in mid-December 2006 (Neal and others, 2008b) persisted into early 2007.

On February 15, a series of Strombolian explosions occurred from Klyuchevskoy's summit, sending ash up to $5.3 \mathrm{~km}(17,400 \mathrm{ft})$ ASL where it drifted to the southwest. At night, incandescence and volcanic bombs rising $300 \mathrm{~m}$ $(1,000 \mathrm{ft})$ above the summit were noted by observers. This sudden increase in activity prompted KVERT to raise the Level of Concern Color Code to ORANGE. Weak explosive activity continued accompanied by elevated earthquake counts, volcanic tremor, and strong thermal anomalies in satellite images. On March 28, a lava flow was seen travelling down the northwestern flank of the volcano. Phreatic boiling produced by interaction of Klyuchevskoy lava flows with glacial ice was noted in late April producing ash-bearing water vapor rich clouds that rose to $7.2 \mathrm{~km}(23,600 \mathrm{ft})$ ASL and drifted more than $250 \mathrm{~km}$ (>155 mi) east and southeast. Lahars were channeled down the northwestern flank of the volcano eventually reaching the Krivaya River $10 \mathrm{~km}$ east of Klyuchi. On May 4, the first of several ash falls occurred in Klyuchi and residents reported hearing the sounds of explosions from the volcano.

On May 17, following a several-day increase in volcanic tremor amplitude, the eruption at Klyuchevskoy intensified. Vulcanian explosions sent ash to an elevation of 9,700 m (31,900 ft) ASL and KVERT raised the Level of Concern Color Code to RED. Satellite imagery showed the ash cloud extending up to $600 \mathrm{~km}(370 \mathrm{mi})$ from the volcano. Lava flow and lahar activity continued accompanied by far-traveled ash clouds as high as $8.5 \mathrm{~km}$ (27,900 ft) ASL into late May. On May 31, a new lava flow was detected on the eastern flank of the volcano; strong phreatic explosions occurred at the front of the lava flow. Despite this, by the end of May seismicity and plume height had decreased somewhat and KVERT downgraded the Level of Concern Color Code to ORANGE on June 1.
Strombolian and Vulcanian explosions continued from the summit crater and both lava flow lobes continued to be active into June (fig. 56). On June 20, seismicity again escalated prompting a return to RED; ash fall occurred on Kozyrevsk, $48 \mathrm{~km}$ (30 mi) west of the volcano. A large cyclonic weather system over Kamchatka on June 20-21 carried Klyuchevskoy ash as far south as Petropavlovsk at an elevation of between 6.5 and $9.5 \mathrm{~km} \mathrm{(21,300} \mathrm{and} \mathrm{31,200}$ $\mathrm{ft})$. Decreased activity prompted a return to ORANGE on June 25, however, ash plumes emanated in all directions from the volcano at different times, extending several hundred kilometers and reaching as high as $6.5 \mathrm{~km}(21,300 \mathrm{ft})$ ASL. A significant thermal anomaly was ever-present in clear satellite images.

The temporary decrease in activity did not last long. On June 28, seismicity ramped up again accompanied by an ash plume as high as $9.5 \mathrm{~km}(30,400 \mathrm{ft})$ ASL and KVERT raised the Level of Concern Color Code to RED. Over the next several days, ash emission was continuous at times in excess of $10 \mathrm{~km}$ (33,000 ft) ASL. Activity decreased again and ORANGE was reinstated on July 4. By July 20, seismicity and ash production had decreased still further and KVERT declared Level of Concern Color Code YELLOW.

Activity continued to decrease and on August 17, after a month of no ash emissions, KVERT announced Level of Concern Color Code GREEN for Klyuchevskoy, where it remained for the rest of 2007. Seismicity remained at background levels with a few shallow earthquakes each day and weak, continuous tremor.

Klyuchevskoy is a classic, symmetrical stratovolcano. At 4,750 m (15,589 ft) ASL, it is the highest of the active European and Asian volcanoes. Klyuchevskoy is frequently active with Strombolian to Vulcanian explosions and occasional lava-flow production from the main vent in the steep-walled summit crater or from flank vents (Khrenov and others, 1991). Explosive eruptions have been recorded in nearly every decade and at multiple times during most years since the early 1700s (Simkin and Siebert, 1994). 


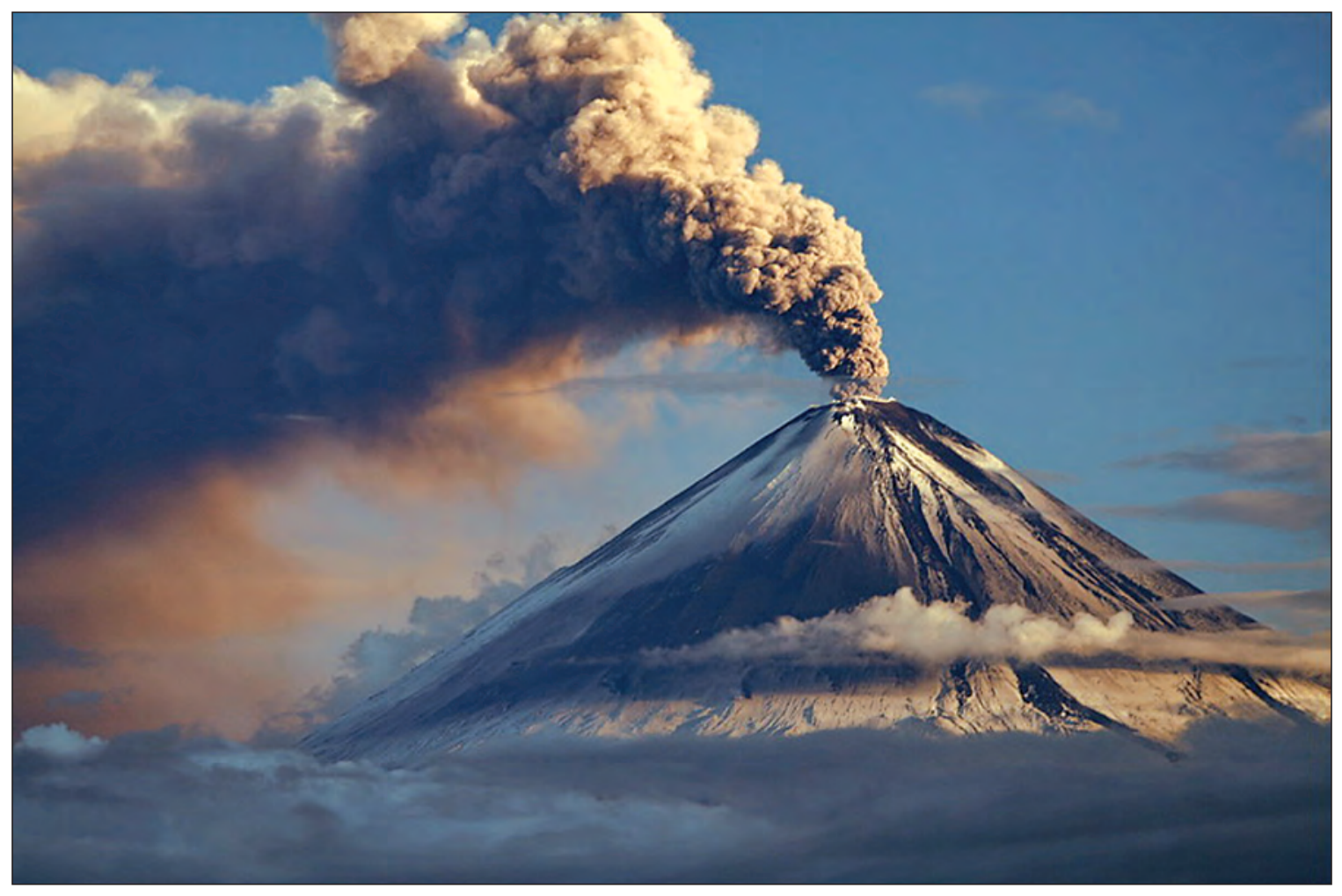

Figure 56. Klyuchevskoy Volcano in eruption, June 2007. Photograph by Y. Demyanchuk, IVS. 


\section{Bezymianny Volcano}

CAVW\# 1000-25-

$55^{\circ} 58^{\prime} \mathrm{N} 160^{\circ} 36^{\prime} \mathrm{E}$

$2,882 \mathrm{~m}(9,456 \mathrm{ft})$

Kamchatka Peninsula, Russia

INTERMITTENT LAVA DOME GROWTH AND EXPLOSIONS

Several episodes of increased thermal outpout (extrusion?), pyroclastic avalanches, ash clouds

The protracted lava dome eruption of Bezymianny Volcano continued in 2007. The volcano began the year quietly at Level of Concern Color Code YELLOW. Typically, a fumarolic plume rose above the active dome and seismicity was slightly above or at background. A thermal anomaly was common coincident with the lava dome as seen in satellite images. Throughout this period, KVERT Information Releases stated that lava dome growth continued. Beginning in April, strong seismicity due to eruptive activity of adjacent Klyuchevskoy Volcano made it difficult to track seismicity at Bezymianny stations.

On May 11, KVERT elevated the Level of Concern Color Code to ORANGE following intensification of the thermal anomaly in the area of the active lava dome. Based on previous experience (Girina and Gorbach, 2006), KVERT noted that increased thermal anomalies reflecting an increase in surface heat flux often preceded powerful explosive eruptions. Seismicity at Bezymianny was obscured by the high level of activity and associated seismicity at Klyuchevskoy, which hampered analysis of the Bezymianny activity by KBGS. Explosive activity did occur on May 11; ash fall was reported in Klyuchi (actually a mixture of ash fall from both Klyuchevskoy and Bezymianny). Satellite images showed ash plumes extending in several directions from the volcano and a large area of thermal anomaly reflected runout of pyroclastic flows southeast of the lava dome. Several days later, hunters reported a lahar deposit along the Sukhaya Khapitsa River east-southeast of the volcano. KVERT surmised that this lahar was formed by interaction of the May 11 pyroclastic flow with snowpack. Bezymianny was downgraded to YELLOW on May 17.
Conditions at Bezymianny were fairly stable until late September when KVERT noted an increase in the size and temperature of the thermal anomaly associated with the summit lava dome. Seismicity suggested pyroclastic flow activity, ash emission fed small ash clouds (several tens of kilometers long) and KVERT suggested that the possibility of a strong explosive eruption had increased.

The expected explosive event occurred on October 14, consisting of two pulses resulting in ash clouds ultimately extending more than 1,000 km (>625 mi) generally east and southeast from the volcano. KVERT elevated the Level of Concern Color Code to RED (fig. 57). By October 16, the level of activity had decreased and KVERT downgraded to ORANGE and then to YELLOW on October 20.

Less than 1 month later on November 10, thermal output from the summit area again increased dramatically and KVERT raised the Level of Concern Color Code to ORANGE and noted the increased possibility of an explosive event. Seismicity remained low, however. Scientists on an over flight on November 9 noted fresh pyroclastic-flow deposits extending $4 \mathrm{~km}(2.5 \mathrm{mi})$ from the dome. The thermal anomaly abated without a major explosion and KVERT downgraded the volcano to YELLOW on November 22 where it remained until the end of the year.

In October 1955, Bezymianny Volcano emerged from a 900-1,000 year period of quiescence commencing an explosive eruption that culminated on March 30, 1956, with the catastrophic failure of the eastern flank, producing a large debris avalanche and lateral blast. Since then, lava extrusion has built a dome that periodically collapses or produces powerful vertical ash emission events, pyroclastic flows, and short-lived but far-traveled ash plumes (Girina and others, 1993; McGimsey and others, 2007). 


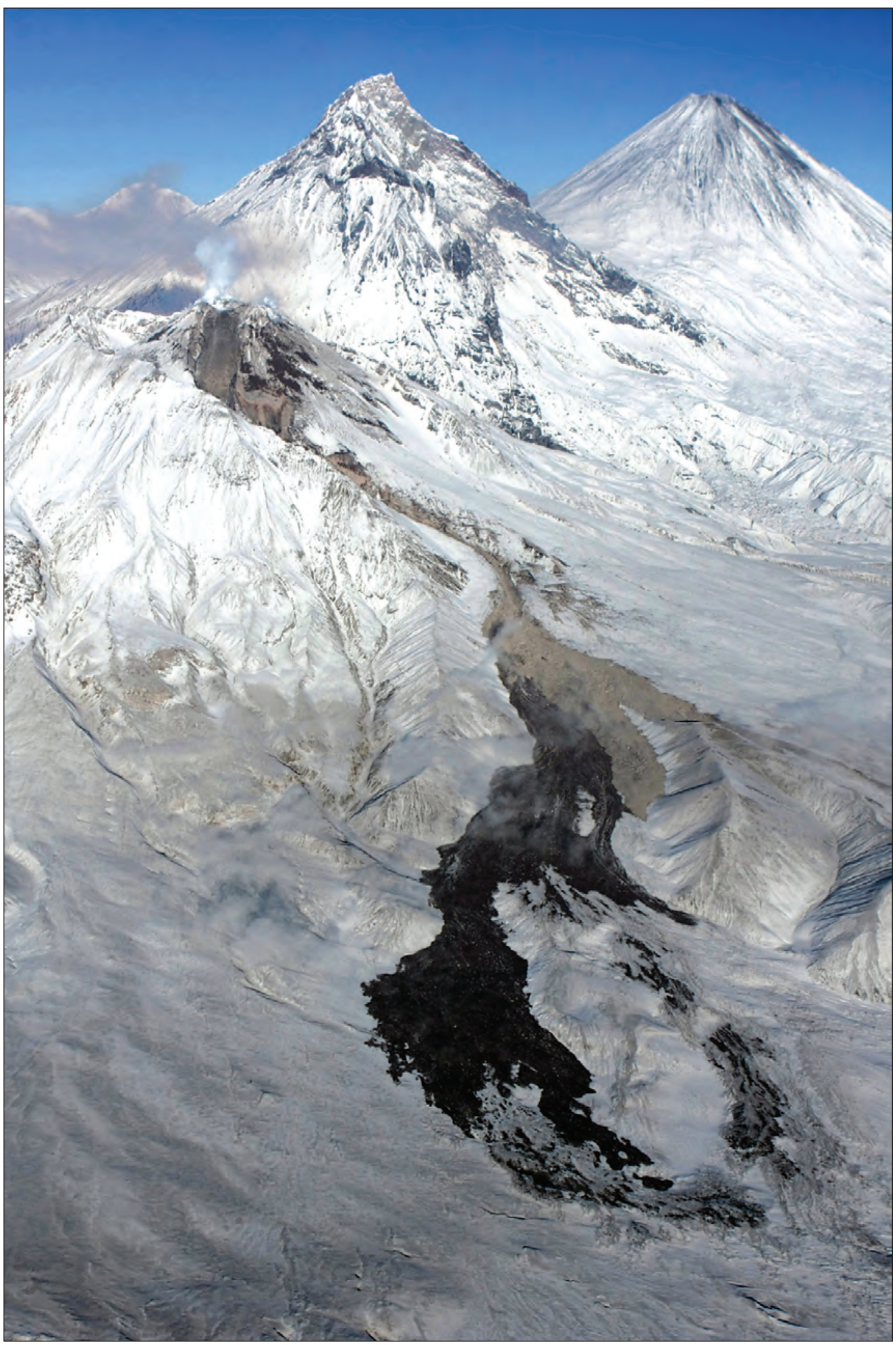

Figure 57. Bezymianny pyroclastic flow deposit from the November 5 eruption (light). The older, lobate pyroclastic flow deposit from the eruption on October 16, 2007, is dark. A fumarolic plume rises from the active lava dome at the summit of Bezymianny. Kamen Volcano and Klyuchevskoy Volcano in the background are inactive. View is to the north. Photograph by Y. Demyanchuk, IVS, November 8, 2007. 


\section{Karymsky Volcano}

CAVW\# 1000-13-

$54^{\circ} 03^{\prime} \mathrm{N} 159^{\circ} 27^{\prime} \mathrm{E}$

$1,486 \mathrm{~m}(4,876 \mathrm{ft})$

Kamchatka Peninsula, Russia

STROMBOLIAN / VULCANIAN ERUPTION CONTINUES INTERMITTENTLY

Low-level ash clouds

Karymsky Volcano has been in nearly constant eruption since the beginning of 1996, and 2007 continued to be an active year for this remote Kamchatkan volcano. Typically, several hundred shallow earthquakes and spasmodic tremor were recorded each day beneath the steep-sided cone.

Seismicity was permissive of intermittent ash explosions; however, with cloudy weather and infrequent direct observations, it was difficult to track details of activity. Clear satellite view of the volcano frequently detected a thermal anomaly in the vicinity of the volcano's summit. Pilots occasionally reported fumarolic and ash plumes extending from the summit crater. The volcano began the year at Level of Concern Color Code ORANGE.

Seismicity increased in late March and low-level $(<5 \mathrm{~km}$; $<3 \mathrm{mi}$ ) ash emissions were confirmed in satellite data (fig. 58). Scientists visited the volcano in April and reported continuing fumarolic and ash emission (fig. 59); a possible lava flow reported by KVERT on April 19 turned out not to be a new flow lobe.

By early June, a lull in ash emissions and lack of thermal anomalies for several weeks prompted KVERT to downgrade
Karymsky to YELLOW on June 7. On June 8, activity abruptly resumed with stronger seismicity and Karymsky upgraded to ORANGE. Intermittent explosive activity (fig. 60) for the next 5 months produced weak ash clouds that rose generally no higher than $5 \mathrm{~km}$ (3 mi) ASL and extended up to $450 \mathrm{~km}$ (280 mi) mostly to the east of the volcano. Activity diminished in late 2007 and KVERT declared Level of Concern Color Code YELLOW on December 6.

Karymsky is the most active volcano on the Kamchatka Peninsula (Simkin and Siebert, 1994). Explosive and effusive-explosive eruptions of andesitic tephra and lava flows alternating with periods of repose are typical of Karymsky (Ivanov and others, 1991). The current phase of unrest began in mid-April 1995 with increasing seismicity and culminated in an explosive eruption that began on January 1, 1996. Initial eruptive activity occurred simultaneously at Karymsky Volcano and from a vent at the northern part of Karymsky Lake, a distance of about 10 km (6 mi; Fedotov, 1998; Belousov and Belousova, 2001). For the next several years, periods of explosive eruptions of ash and small blocks alternated with periods of lava-flow production. 


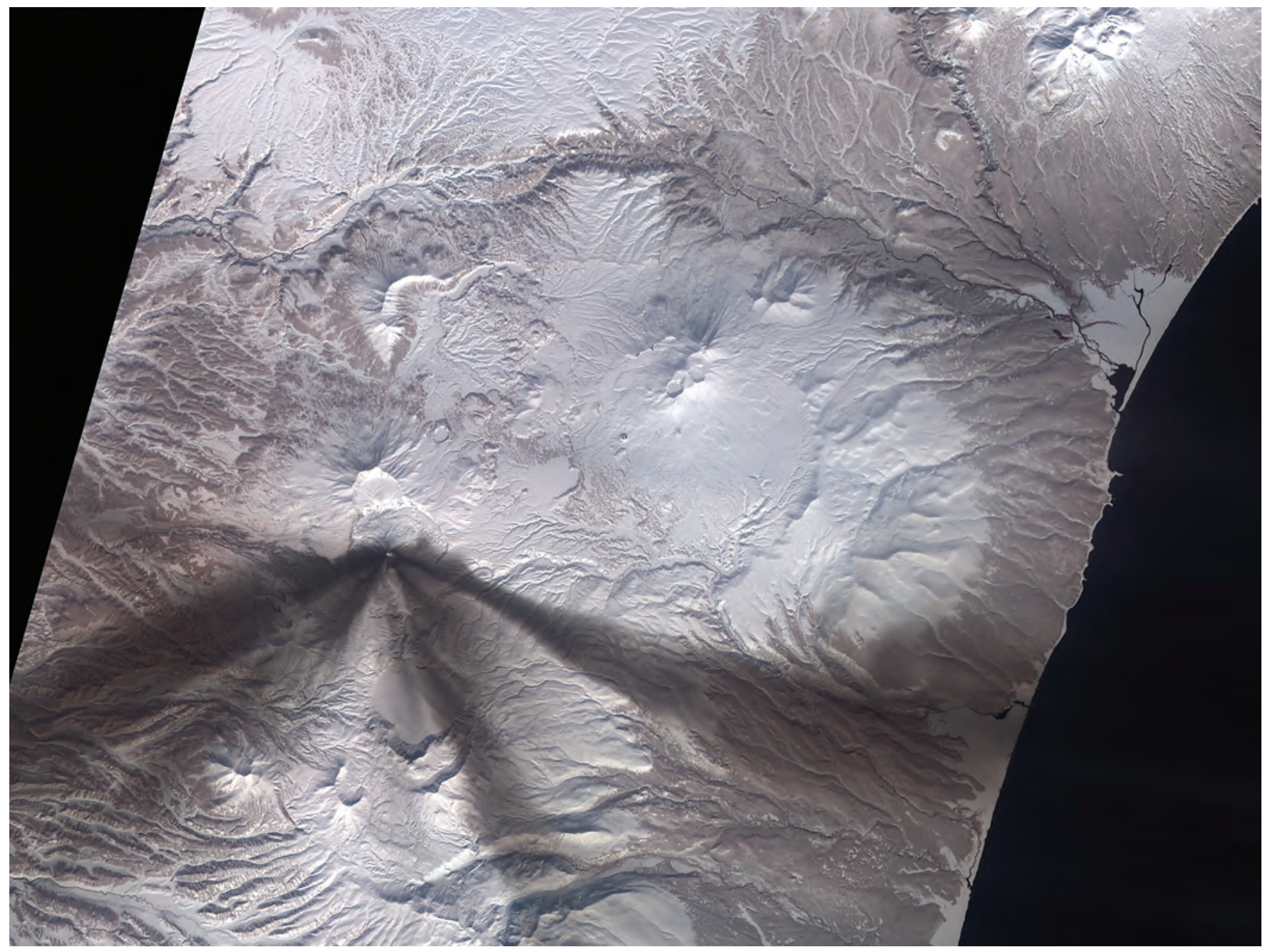

Figure 58. ASTER satellite image of Karymsky Volcano, March 25, 2007. The dark radiating spokes are very recent ash fall blankets on the snow-covered terrain. A wisp of fumarolic plume is visible over the summit of the volcano, which sits inside the prominent Academy Nauk Caldera structure. ASTER data courtesy of NASA/GSFC/METI/ERSDAC/JAROS, and U.S./Japan ASTER Science Team. 


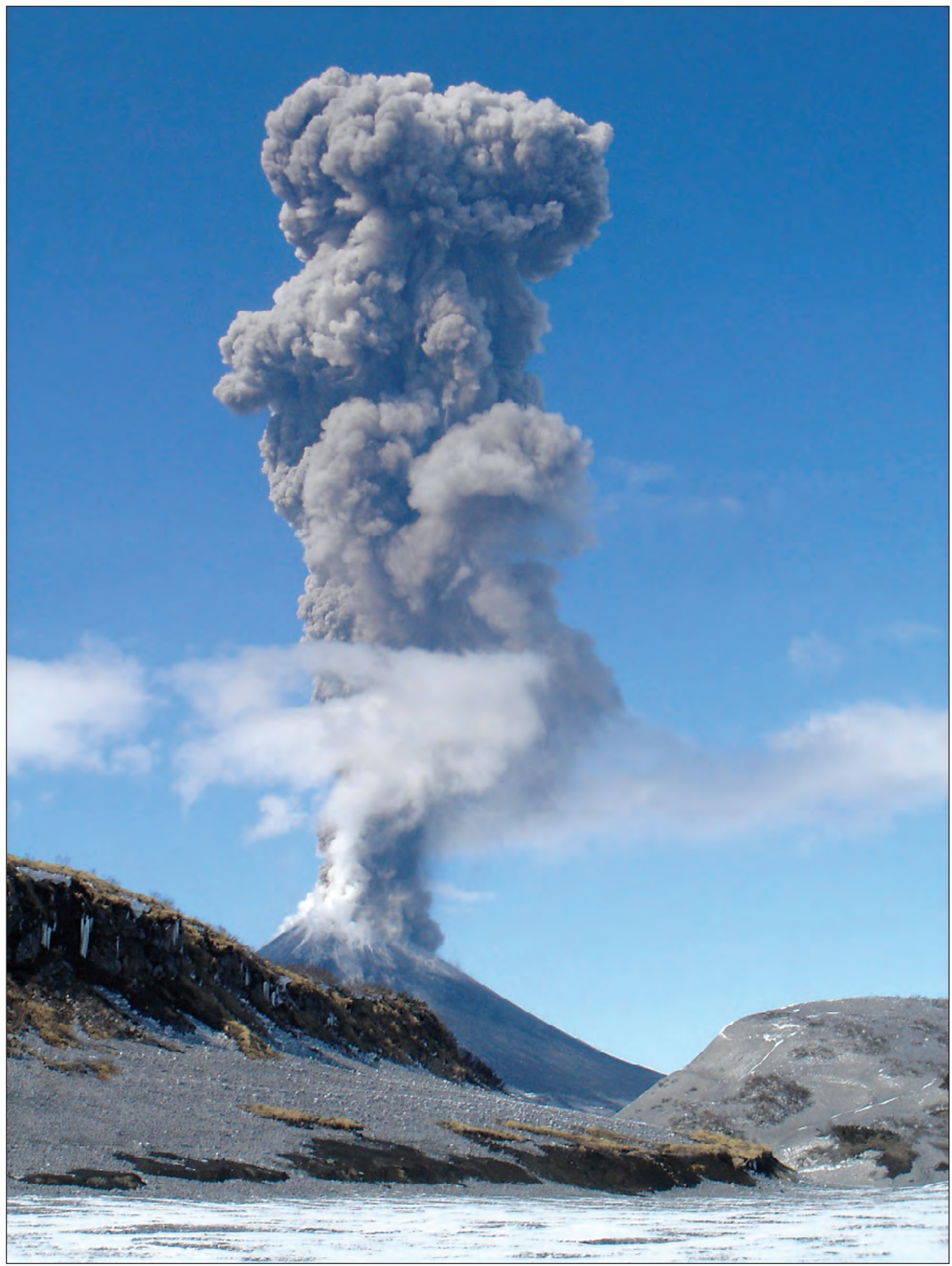

Figure 59. Ash explosion from Karymsky Volcano, April 21, 2007. Photograph by N. Malik, IVS. 


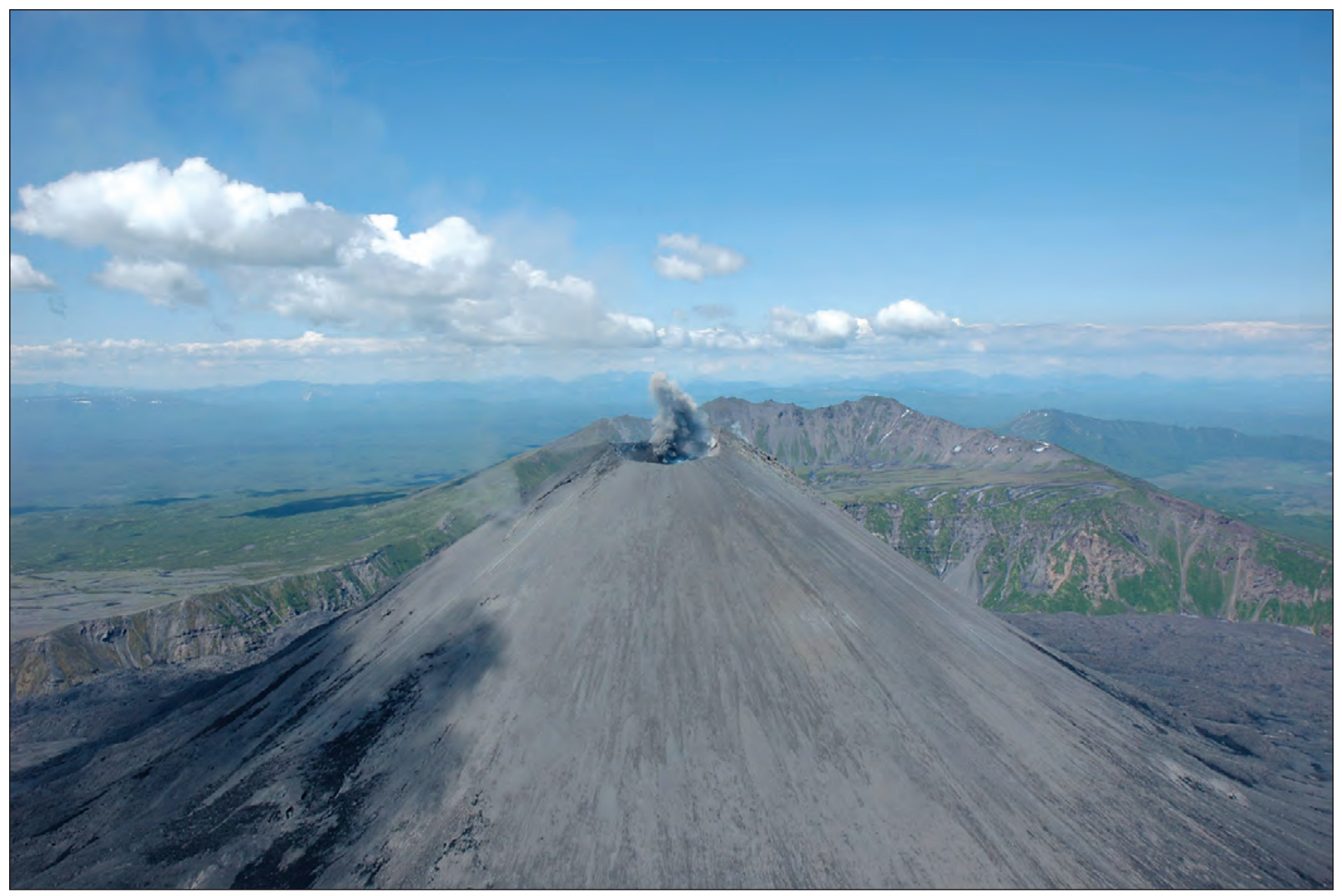

Figure 60. Ash explosion from Karymsky Volcano, July 12, 2007. 


\begin{tabular}{|l|l|}
\hline Gorely Volcano & Mutnovsky Volcano \\
CAVW\# $1000-07-$ & CAVW\# $1000-06-$ \\
$52^{\circ} 33^{\prime} \mathrm{N} 158^{\circ} 02^{\prime} \mathrm{E}$ & $52^{\circ} 27^{\prime} \mathrm{N} 158^{\circ} 12^{\prime} \mathrm{E}$ \\
$1,829 \mathrm{~m}(6,001 \mathrm{ft})$ & $2,323 \mathrm{~m}(7,621 \mathrm{ft})$ \\
& \\
$\begin{array}{l}\text { Kamchatka Peninsula, Russia } \\
\text { INCREASED SEISMICITY AND FUMAROLIC OUTPUT } \\
\text { LOW-level ash clouds }\end{array}$ & PHREATIC EXPLOSION \\
\hline
\end{tabular}

KVERT reported an increase in seismicity in the vicinity of Gorely and Mutnovsky Volcanoes about 75 km (45 mi) southwest of Petropavlovsk, on December 24. Initial analysis suggested the source was likely Gorely, where fumarolic output increased with the rise in seismicity. KVERT raised the Level of Concern Color Code to YELLOW. Gorely last erupted in 1986 sending ash to about $5 \mathrm{~km}(16,400 \mathrm{ft})$ ASL.

KBGS scientists were unable to verify the exact volcanic source and so KVERT expanded the raised concern to include Mutnovsky Volcano on December 27. Mutnovsky is only $20 \mathrm{~km}$ (12 mi) southeast of Gorely and both volcanoes are monitored by a single seismometer.

Later KVERT learned of a phreatic explosion that had occurred at Mutnovsky on April 16 or 17, 2007. The event was confirmed by field evidence of ejecta (fig. 61) and analysis of fresh ash fall; evidence for this event also was noted in hindsight on satellite imagery (Girina and others, 2008a). Weak volcanic tremor had been detected 15 days prior to the phreatic explosion, reaching a maximum amplitude 2 days prior to the event. Prior to 2007, Mutnovsky last produced phreatic explosions in 2000 (Neal and others, 2004).
Both volcanoes returned to Level of Concern Color Code GREEN in early January 2008 when activity reverted to background levels.

Mutnovsky Volcano is considered one of the most active volcanoes of southern Kamchatka. It is composed of four overlapping stratovolcanoes, the youngest of which is early Holocene in age. Simkin and Siebert (1994) record 11 eruptions in the 20th century, most of which were small phreatic explosions. There is debate about the accuracy of a lava flow reported in 1904. Commercial development of the volcano for geothermal power is underway.

Gorely Volcano consists of a complex set of several overlapping stratovolcanoes within a 9-by-13.5-km (5.6-8.4 mi), late Pleistocene caldera (Simkin and Siebert, 1994). Many of the several dozen flank craters contain lakes. Historical eruptions have been dominated by Vulcanian and Phreatic explosions; Siebert and Simkin (2002-) list 13 possible eruptions since about 1700, the most recent in 1986. 


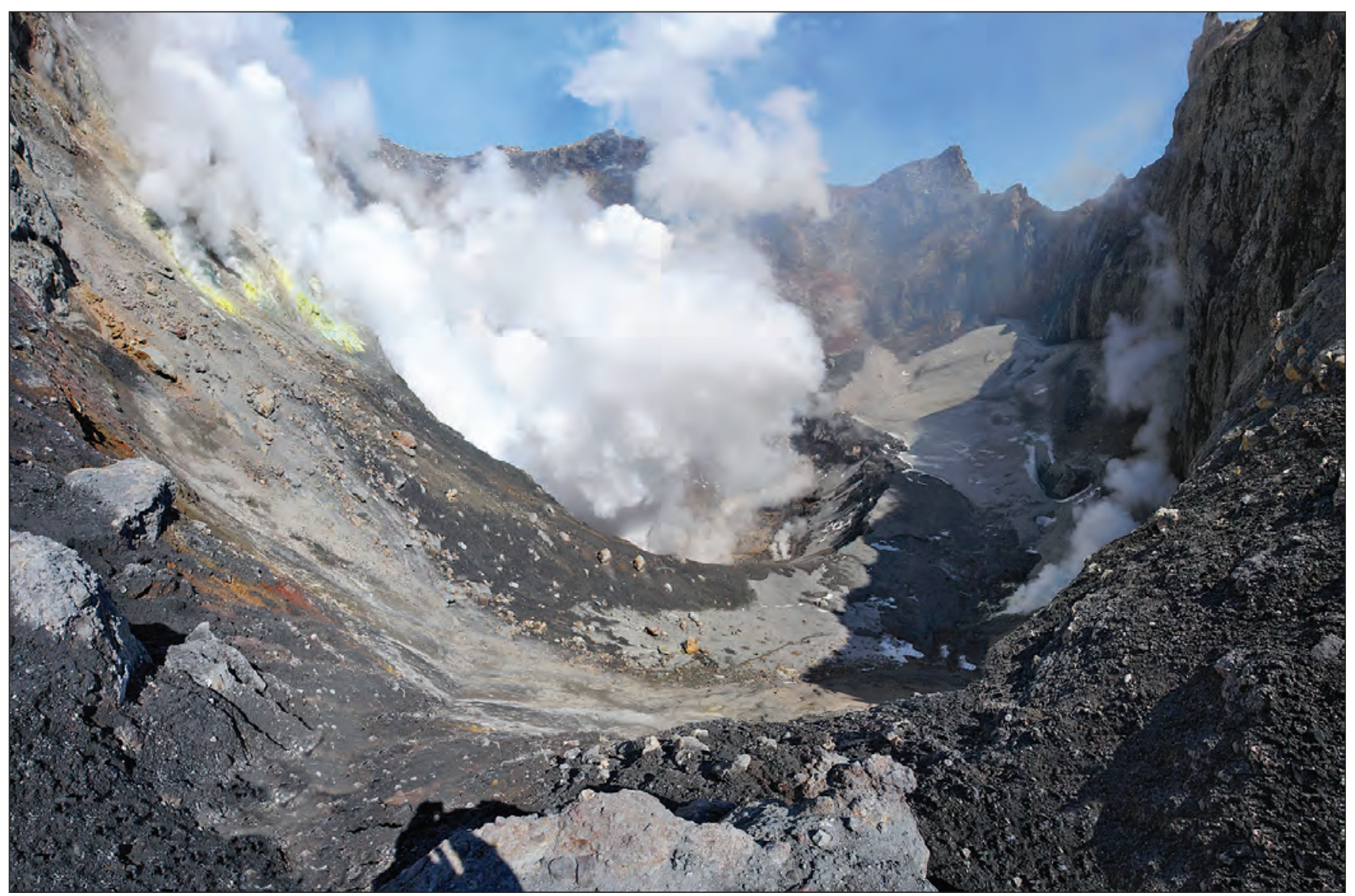

Figure 61. Explosive vent in the active crater of Mutnovsky Volcano formed by the phreatic explosion in mid-April. Photograph by M. Zelensky, IVS, April 17, 2007. 


\title{
Chikurachki Volcano
}

\author{
CAVW\# 0900-36- \\ $50^{\circ} 19^{\prime} \mathrm{N} 155^{\circ} 28^{\prime} \mathrm{E}$ \\ $1,816 \mathrm{~m}(5,958 \mathrm{ft})$ \\ Paramushir Island, Russia \\ ASH Explosions
}

On March 4, KVERT received information from local observers about ash explosions from Chikurachki Volcano on Paramushir Island. The ash column was estimated to rise as high as $1,500 \mathrm{~m}(5,000 \mathrm{ft})$ above the summit (or about 11,000 ft ASL; Girina and others, 2008b). KVERT did not assign a new color code due to the hiatus in operations. Activity persisted over the next several days. AVO satellite analysts reported an ash plume extending up to $125 \mathrm{~km}$ (78 mi) from the volcano on March 7. Ash emission appeared continuous in satellite imagery for several hours; however, comparison of imagery to the PUFF tracking model suggested an elevation of the ash cloud of no more than $3 \mathrm{~km}(2 \mathrm{mi})$ ASL. Over the next month, Chikurachki ash clouds detected in satellite imagery stayed below about $5 \mathrm{~km}$ (3 mi) ASL. An $\mathrm{SO}_{2}$ cloud from this eruption was captured in OMI satellite imagery on March 16; this cloud extended at least $580 \mathrm{~km}$ (360 mi) northwest from the volcano over the Sea of Okhotsk. When KVERT resumed formal operations in April, continuing activity at Chikurachki including ash fall reported at Severo-Kurilsk prompted KVERT to raise the Level of Concern Color Code to ORANGE. Ash clouds continued to be visible both in satellite imagery and by local citizens until April 16. Ash plumes remained below 5 km (3 mi) ASL and extended several tens of $\mathrm{km}$ downwind. By April 27, more than 1 week after the last reported ash emission from Chikurachki, KVERT downgraded the volcano to YELLOW and later to GREEN on May 11.

After 3 months of quiescence, satellite images of Chikurachki captured ash clouds extending about $120 \mathrm{~km}$
(74 mi) southeast over the North Pacific Ocean. Observers from Severo-Kurilsk reported that eruptive activity had resumed on August 18, and KVERT raised the Level of Concern Color Code to ORANGE on August 19 where it remained until November 15. During these 3 months, at least one ash fall occurred at Podgorny (20 km or $12 \mathrm{mi}$ southeast of the volcano) and on Atlasova Island about $60 \mathrm{~km}$ (37 mi) north of the volcano. Ash clouds generally rose no higher than $5 \mathrm{~km}$ (3 mi) ASL although they were traceable at times several hundred kilometers downwind in satellite images mostly to the east (figs. 62 and 63). KVERT downgraded the volcano to YELLOW on November 15 and GREEN on November 22 after several weeks of inactivity in satellite images and no further reports from residents or scientists on Paramushir (Girina and others, 2008b).

Chikurachki is the highest volcano on Paramushir Island (fig. 64) and it was last active in 2003-2005 with intermittent ash clouds reaching about $6 \mathrm{~km}$ (3.7 mi) ASL (McGimsey and others, 2007; Girina and others, 2008b). Direct information about the volcano is limited and intermittent because it is not monitored seismically, and few people live nearby. Situated $105 \mathrm{~km}$ (65 mi) southwest of the tip of the Kamchatkan Peninsula, Chikurachki is a distinctive cone with a mantle of red, oxidized basaltic andesite scoria on its upper flanks (Gorshkov, 1970; Simkin and Siebert, 1994). There are at least six known historical eruptions attributed to Chikurachki, including its largest historical eruption of about $1 \mathrm{~km}^{3}$ $\left(0.24 \mathrm{mi}^{3}\right)$ of material in 1853 . 


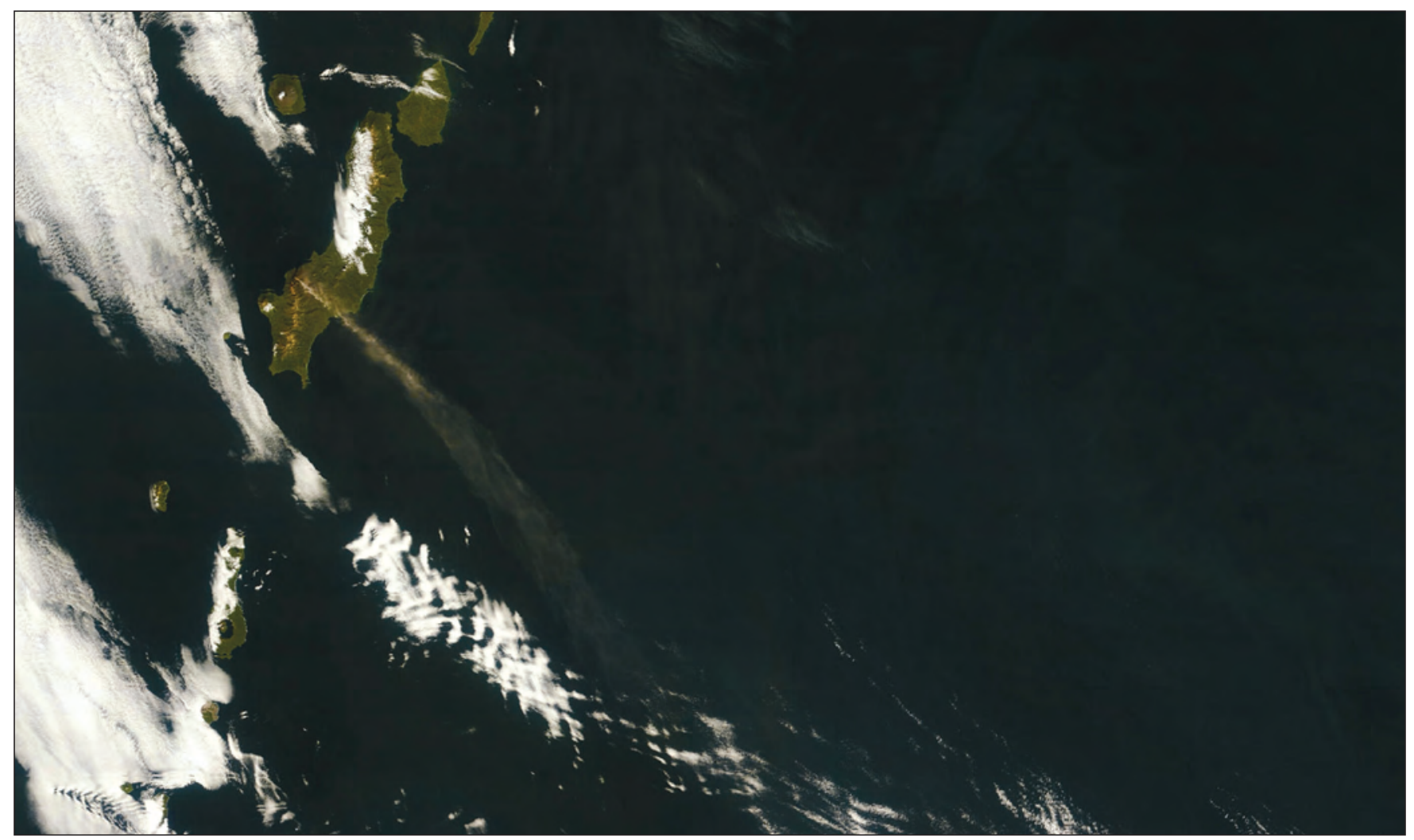

Figure 62. MODIS image of Chikurachki plume on September 19, 2007.

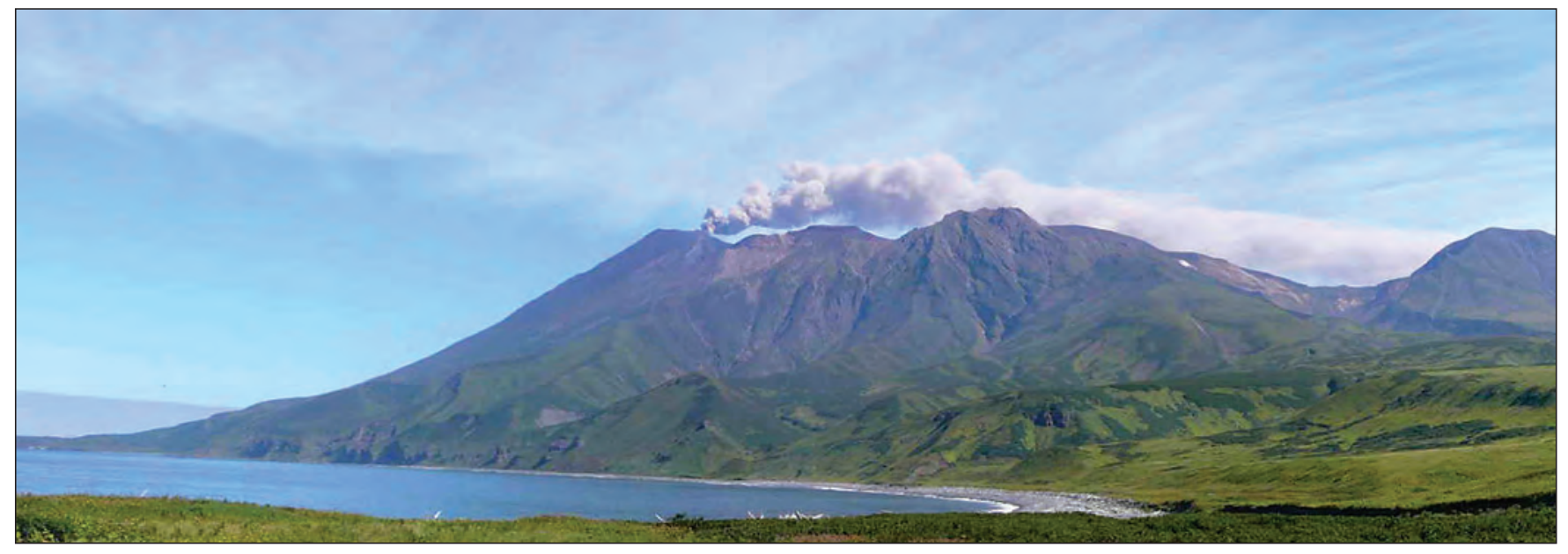

Figure 63. Chikurachki ash plume, extending to the southeast from the volcano. By L. Kotenko, IVS, September 8, 2007. 


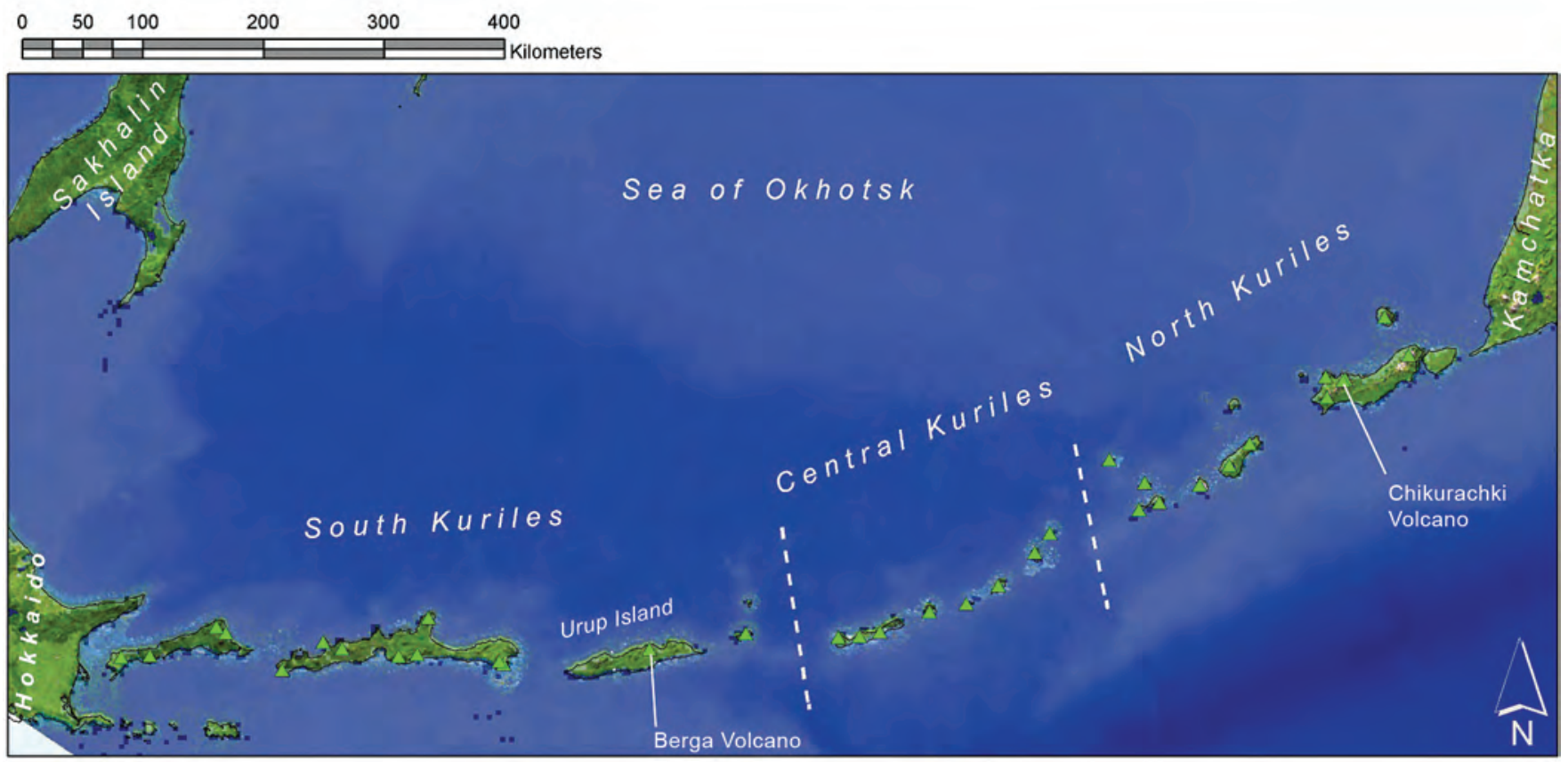

Figure 64. Kurile Islands showing Berga and Chikurachki Volcanoes. Figure courtesy R. Wessels, AVO/USGS.

\section{Volcanic Activity, Central and Southern Kurile Islands}

The Institute of Marine Geology and Geophysics (IMGG), the host institute for the Sakhalin Volcanic Eruption Response Team (SVERT; Rybin and others, 2004; Neal and others, 2008a), reports on activity at Kurile Island volcanoes. SVERT uses twice-daily MODIS imagery of the Kurile Islands, time-delayed seismic data from Kunashir and Iturup Islands, and visual observations from several southern Kurile
Islands. By agreement between SVERT and KVERT, the northernmost Kurile Islands of Paramushir and Alaid are under the reporting jurisdiction of KVERT. In 2007, none of the central or southern Kurile Island volcanoes showed unequivocal elevated signs of activity. $\mathrm{A} \mathrm{SO}_{2}$ cloud detected by OMI was suggestive of activity at Berga Volcano on Urup Island in the South Kuriles, however, it is equally likely that it was from Chikurachki Volcano that was active at the time. A communications test for a hypothetical eruption in the Kuriles was conducted in the autumn of 2007 (Neal and others, 2008a). 


\section{Berga (?)}

CAVW\# 0900-12-

$46^{\circ} 03^{\prime} \mathrm{N} 150^{\circ} 04^{\prime} \mathrm{E}$

$980 \mathrm{~m}(3,215 \mathrm{ft})$

Urup Island, Kuriles, Russia

POSSIBLE ERUPTION AND GAS OUTBURST?

Simon Carn (then at University of Maryland Baltimore County) contacted AVO, KVERT, and SVERT on April 14, 2007, to share an Aura/OMI image of a sulfur dioxide cloud milling about the southern Kurile Islands (fig. 65). He recognized that the likely source was Chikurachki Volcano, then active, but noted its position well south of Paramushir Island.

Peter Webley of AVO performed retrospective PUFF runs for Chikurachki Volcano starting at 0000 on April 13, 1200 on April 12, and 1800 on April 12. Using the Navy Operational Global Atmospheric Prediction System (NOGAPS) model, the predicted plume trajectory did not come close to the observed position of the cloud in the OMI image. He noted that the nearest young volcano was Berga on Urup Island, and suggested this as a possible source. AVO contacted SVERT who had seen nothing on MODIS imagery used during their routine, daily monitoring. They noted, however, that Berga did see a possible increase in fumarolic activity in 2005 (McGimsey and others, 2007). No further action was taken.

\section{Aura/OMI - 04/13/2007 03:11-03:15 UT - Orbit 14589}

$\mathrm{SO}_{2}$ mass: $2.580 \mathrm{kt}$; Area: $77732 \mathrm{~km}^{2} ; \mathrm{SO}_{2} \max : 3.80 \mathrm{DU}$ at lon: 153.44 lat: 44.80

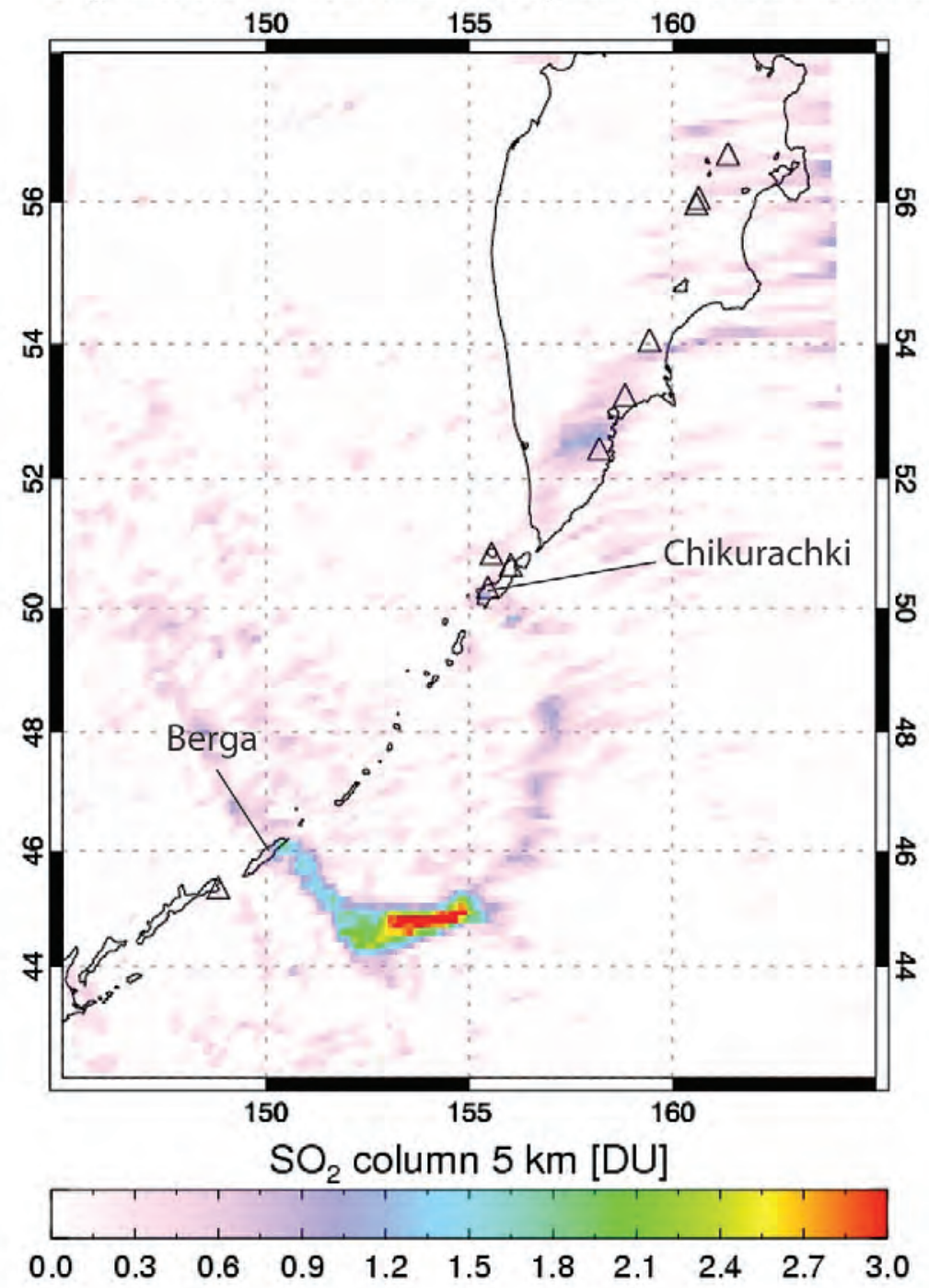

Figure 65. Sulfur dioxide cloud detected in the Kurile Islands on April 14,2007 , by the OMI sensor. Figure courtesy S. Carn, University of Maryland Baltimore County. 


\section{Summary}

The Alaska Volcano Observatory and colleagues at collaborating institutions in Russia responded to volcanic unrest at or near nine separate volcanic centers in Alaska, including an eruption from one of Alaska's most frequently active volcanoes, Pavlof. Multiple explosive episodes from ongoing eruptions at several Kamchatkan volcanoes sent ash repeatedly across the heavily traveled North Pacific and Russian Trans-East air routes, however, no aircraft encounters with ash occurred.

\section{Acknowledgments}

This report represents the work of the entire Alaska Volcano Observatory, colleagues from other USGS Volcano Observatories, staff at cooperating agencies, and the public. Russian activity documented here reflects tenacious monitoring, documentation, and analysis by scientists at the Institute of Volcanology and Seismology, the Kamchatkan Branch of Geophysical Surveys, and the Institute of Marine Geology and Geophysics. In particular, we thank Sergey Senyukov of KBGS for his generous sharing of information and insights. We also acknowledge the significant contributions of our colleagues at Alaska Division of Geological and Geophysical Surveys (AKDGGS) for design and maintenance of the Alaska Volcano Observatory image database, a powerful tool for review of activity through the year. Technical reviews by Michelle Coombs and Cheryl Cameron improved the content and presentation. All images and photographs in this report are from our colleagues and the public and are appreciated and used with permission. The authors wish to acknowledge partial funding support for this work from the Federal Aviation Administration.

\section{Sources of Photographs in this Report and Other Images of Alaska and Russia}

Online sources of digital images from this report and related to volcanoes covered in this report:

http://libraryphoto.cr.usgs.gov/

http://www.avo.alaska.edu/images/

http://geopubs.wr.usgs.gov/dds/dds-39/

http://geopubs.wr.usgs.gov/dds/dds-40/

http://www.kscnet.ru/ivs/kvert/current/index eng.php

\section{References Cited}

Bacon, C.R., Sisson, T.W., and Mazdab, F.K., 2007, Young cumulate complex beneath Veniaminof caldera, Aleutian arc, dated by zircon in erupted plutonic blocks: Geology, v. 35, n. 6, p. 491-494, doi: 10.1130/G23446A.1.

Belousov, A., and Belousova, M., 2001, Eruptive process, effects, and deposits of the 1996 and the ancient basaltic phreatomagmatic eruptions in Karymsky Lake, Kamchatka, Russia, in White, J.D., and Riggs, N.R. (eds.), Lacustrine Volcanoclastic Sedimentation: Special Publications of the International Association of Sedimentologists, v. 30, p. 35-60, accessed July 6, 2010, at http://www.kscnet.ru/ ivs/lavdi/staff/belousov/lake.pdf.

Bogoyavlenskaya, G.E., Braitseva, O.A., Melekestsev, I.V., Kiriyanov, V.Yu., and Miller, C.D., 1985, Catastrophic eruptions of the directed-blast type at Mount St. Helens, Bezymianny and Shiveluch Volcanoes: Journal of Geodynamics, v. 3, issues 3-4, p. 189-218.

Cervelli, P.F., and West, M., 2007, The 2006 eruption of Fourpeaked Volcano, Katmai National Park, Alaska: Eos Trans. AGU, 88(52), Fall Meeting Supplement, Abstract V31E-0719.

Coombs, M.L., Bull, K.F., Vallance, J.W., Schneider, D.J., Thoms, E.E., Wessels, R.L., and McGimsey, R.G., 2010, Timing, distribution, and volume of proximal products of the 2006 eruption of Augustine Volcano, in Power, J.A., Coombs, M.L., and Freymueller, J.T., eds., The 2006 eruption of Augustine Volcano, Alaska: U.S. Geological Survey Professional Paper 1769.

Dean, K.G., Dehn, Jonathan, Papp, K.R., Smith, Steve, Izbekov, Pavel, Peterson, Rorik, Kearney, Courtney, and Steffke, Andrea, 2004, Integrated satellite observations of the 2001 eruption of Mt. Cleveland, Alaska: Journal of Volcanology and Geothermal Research, v. 135, p. 51-73.

Dixon, J.P., Stihler, S.D., Power, J.A., and Searcy, Cheryl, 2008, Catalog of earthquake hypocenters at Alaska volcanoes-January 1 through December 31, 2007: U.S. Geological Survey Data Series 367, 82 p. (Also available at http://pubs.usgs.gov/ds/367/pdf.)

Fedotov, S.A., 1998, The 1996 eruption in the Karymsky volcanic center and related events: Special issue of Volcanology and Seismology, v. 19, n. 5, p. 521-767.

Gardner, C.A., and Guffanti, M.C., 2006, U.S. Geological Survey's alert notification system for volcanic activity: U.S. Geological Survey Fact Sheet 2006-3139, 4 p. (Also available at http://pubs.usgs.gov/fs/2006/3139/.) 
Girina, O.A., Bogoyavlenskaya, G.E., and Demyanchuk, Yu.V., 1993, Bezymianny eruption of August 2, 1989: Volcanology and Seismology, v. 15, no. 2, p. 135-144 (in Russian).

Girina, O.A., and Gorbach, N.V., 2006, January 11, 2005 eruption of Bezymyanny volcano: Proceedings of International Symposium "Problems of Explosive Volcanism”, Petropavlovsk-Kamchatskiy, p. 87-97 (in Russian).

Girina, O.A., Demyanchuk, Yu.V., Melnikov, D.V., Malik, N.A., Manevich, A.G., Nuzhdaev, A.A., and Kotenko, L.V., 2008a, Active volcanoes of Kamchatka and Northern Kuriles in 2007 January-June: Geophysical monitoring and seismic safety problems of the Far East of the Russia: Petropavlovsk-Kamchatsky, KB GS RAS, 2007, v.1. p. 68-72. (in Russian): http://emsd.iks.ru/konf071112/lib1. php.

Girina, O.A., Malik, N.A., and Kotenko, L.V., 2008b, Activity of the volcano Chikurachki (Paramushir Island, Northern Kuriles) in 2002-2007 according to KVERT data: Reporter KRAUNS, Earth's sciences, v. 1, no. 11, p. 6667-73 (in Russian).

Gorshkov, G.S., 1970, Catalog of the active volcanoes of the world including solfatara fields, Part VII, Kurile Islands: International Volcanology Association, Via Tasso 199, Napoli, Italy, 99 p.

Ivanov, B.V., Braitseva, O.A., and Zubin, M.I., 1991, Karymsky Volcano, chapter 21, in Fedotov, S.A., and Masurenkov, Yu.P., eds., Active volcanoes of Kamchatka, Moscow: Nauka Publishers (Moscow), v. 2, p. 202-203.

Khrenov, A.P., Dvigalo, V.N., Kirsanov, I.T., Fedotov, S.A., Gorel'chik, I., and Zharinov, N.A., 1991, Klyuchevskoy Volcano, chapter 6, in Fedotov, S.A., and Masurenkov, Yu.P., eds., Active volcanoes of Kamchatka, Moscow: Nauka Publishers (Moscow): v. 1, p. 146-163.

Kirianov, V.Yu., Neal, C.A., Gordeev, E.I., and Miller, T.P., 2002, Kamchatkan Volcanic Eruptions Response Team (KVERT): U.S. Geological Survey Fact Sheet 064-02, 2 p., in English and Russian. (Available in English at http://pubs. usgs.gov/fs/2002/fs064-02/fs064-02.pdf.)

Lu, Zhong, 2007, InSAR imaging of volcanic deformation over cloud-prone areas-Aleutian Islands: Photogrammetric Engineering and Remote Sensing, v. 73, no. 3, p. 245-257.
Lu, Zhong, Dzurisin, Daniel, Wicks, C.J., Power, John, Kwoun, O., and Rykhus, R., 2007, Diverse deformation patterns of Aleutian volcanoes from satellite interferometric synthetic aperture radar (InSAR), in Eichelberger, John, Gordeev, Evgenii, Kasahara, Minoru, Izbekov, Pavel, and Lees, Jonathan, eds., Volcanism and Tectonics of the Kamchatka Peninsula and Adjacent Arcs, American Geophysical Union Monograph Series 172, p. 249-261.

Lu, Zhong, Wicks, Charles, Kwoun, Ohig, Power, J.A., and Dzurisin, Daniel, 2005, Surface deformation associated with the March 1996 earthquake swarm at Akutan Island, Alaska, revealed by C-band ERS and L-band JERS radar interferometry: Canadian Journal of Remote Sensing, v. 31, p. 7-20.

Lu, Zhong, Wicks, Charles, Jr., Dzurisin, Daniel, Power, John, Thatcher, Wayne, and Masterlark, Timothy, 2003, Interferometric synthetic aperture radar studies of Alaska volcanoes: Earth Observation Magazine, v. 12, no. 3, p. 8-18.

Lu, Zhong, Wicks, C., Power, J.A., and Dzurisin, D., 2000, Ground deformation associated with the March 1996 earthquake swarm at Akutan volcano, Alaska, revealed by satellite radar interferometry: Journal of Geophysical Research, v. 105, n. 89, p. 21,483-21,496.

McGee, K.A., Doukas, M.P., McGimsey, R.G., Neal, C.A., and Wessels, R.L., 2008, Atmospheric contribution of gas emissions from Augustine Volcano, Alaska during the 2006 eruption: Geophysical Research Letters, v. 35, L03306, doi: 10.1029/2007GL032301, 5 p.

McGee, K.A., Doukas, M.P., McGimsey, R.G., Neal, C.A., and Wessels, R.L., 2010, Emission of $\mathrm{SO}_{2}, \mathrm{CO}_{2}$, and $\mathrm{H}_{2} \mathrm{~S}$ from Augustine Volcano, 2002-2008, in Power, J.A., Coombs, M.L., and Freymueller, J.T., eds., The 2006 eruption of Augustine Volcano, Alaska: U.S. Geological Survey Professional Paper 1769.

McGimsey, R.G., Neal, C.A., and Doukas, M.P., 1995, 1992 volcanic activity in Alaska-Summary of events and response of the Alaska Volcano Observatory: U.S. Geological Survey Open-File Report 95-83, 26 p. (Also available at http://pubs.er.usgs.gov/usgspubs/ofr/ofr9583.)

McGimsey, R.G., and Neal, C.A., 1996, 1995 Volcanic activity in Alaska and Kamchatka-Summary of events and response of the Alaska Volcano Observatory: U.S. Geological Survey Open-File Report 96-738, 23 p. (Also available at http://geopubs.wr.usgs.gov/open-file/of96738/1995 Summary.pdf.) 
McGimsey, R.G., and Wallace, K.L., 1999, 1997 Volcanic activity in Alaska and Kamchatka-Summary of events and response of the Alaska Volcano Observatory: U.S. Geological Survey Open-File Report 99-448, 42 p. (Also available at http://geopubs.wr.usgs.gov/open-file/of99-448/.)

McGimsey, R.G., Neal, C.A., and Girina, Olga, 2004, 1999 Volcanic activity in Alaska and Kamchatka-Summary of events and response of the Alaska Volcano Observatory: U.S. Geological Survey Open-File Report OF 2004-1033, 49 p. (Also available at http://pubs.usgs.gov/of/2004/1033/.)

McGimsey, R.G., Neal, C.A., and Girina, O.A., 2005a, 2001 Volcanic activity in Alaska and Kamchatka-Summary of events and response of the Alaska Volcano Observatory: U.S. Geological Survey Open-File Report 2004-1453, 53 p. (Also available at http://pubs.usgs.gov/of/2004/1453/ of2004-1453.pdf.)

McGimsey, R.G., Neal, C.A., and Girina, O.A., 2005b, 2003 Volcanic activity in Alaska and Kamchatka-Summary of events and response of the Alaska Volcano Observatory: U.S. Geological Survey Open-File Report 2005-1310, 58 p. (Also available at http://pubs.usgs.gov/of/2005/1310/ of2005-1310.pdf.)

McGimsey, R.G., Neal, C.A., Dixon, J.P., and Ushakov, Sergey, 2007, 2005 Volcanic activity in Alaska, Kamchatka, and the Kurile Islands_-Summary of events and response of the Alaska Volcano Observatory: U.S. Geological Survey Scientific Investigations Report 2007-5269, 94 p. (Also available at http://pubs.usgs.gov/sir/2007/5269/pdf/ sir20075269.pdf.)

McNutt, S.R., 1989, Some seismic precursors to eruptions at Pavlof Volcano, Alaska, October 1973-April 1986, in Latter, J.H. (ed.), IAVCEI Proc. Volcanology, 1, p. 463-485.

McNutt, S.R., 1987, Volcanic tremor at Pavlof Volcano, Alaska, October 1973-April 1986: PAGEOPH, 125, p. 1051-1077.

McNutt, S.R., Miller, T., and Taber, J.J., 1991, Pavlof Volcano: Seismological and geological evidence of increased explosivity during the 1986 eruptions: Bulletin of Volcanology, v. 53, p. 86-98.

Miller, T.P., McGimsey, R.G., Richter, D.H., Riehle, J.R., Nye, C.J., Yount, M.E., and Dumoulin, J.A., 1998, Catalog of the historically active volcanoes of Alaska: U.S. Geological Survey Open-File Report 98-582, 104 p. (Also available at http://www.avo.alaska.edu/downloads/catalog.php.)

Miller, T.P., and Chouet, B.A., 1994, The 1989-1990 eruptions of Redoubt Volcano: An inroduction, in Miller, T.P., and Chouet, B.A., eds., Journal of Volcanology and Geothermal Research Special Issue, v. 62, nos. 1-4, p. 1-10.
Miller, T.P., and Smith, R.L., 1987, Late Quaternary calderaforming eruptions in the eastern Aleutian arc, Alaska: Geology, v. 15, n. 5, p. 434-438.

Motyka, R.J., Liss, S.A., Nye, C.J., and Moorman, M.A., 1993, Geothermal resources of the Aleutian arc: Alaska Division of Geological and Geophysical Surveys Professional Report 114, 17 p., 4 sheets, scale 1:1,000,000.

Murray, T.L., and Endo, E.T., 1992, A real-time seismic amplitude measurement system (RSAM): U.S. Geological Survey Bulletin B1966, p. 5-10.

Neal, Christina, Girina, Olga, Senyukov, Sergey, Rybin, Alexander, Osiensky, Jeffrey, Izbekov, Pavel, and Ferguson, Gail, 2009, Russian eruption warning systems for aviation: Natural Hazards, v. 50, 18 p., doi:10.1007/s11069-0099347-6.

Neal, C.A., Doukas, M.P., and McGimsey, R.G., 1995, 1994 Volcanic activity in Alaska-Summary of events and response of the Alaska Volcano Observatory: U.S. Geological Survey Open-File Report 95-271, 19 p. (Also available at http://geopubs.wr.usgs.gov/open-file/of95-271/.)

Neal, C.A., and McGimsey, R.G., 1997, 1996 Volcanic activity in Alaska and Kamchatka-Summary of events and response of the Alaska Volcano Observatory: U.S. Geological Survey Open-File Report 97-433, 34 p. (Also available at http://pubs.er.usgs.gov/djvu/OFR/1997/ ofr 97 433.djvu.)

Neal, C.A., McGimsey, R.G., and Chubarova, Olga, 2004, 2000 Volcanic activity in Alaska and KamchatkaSummary of events and response of the Alaska Volcano Observatory: U.S. Geological Survey Open-File Report 2004-1034, 37 p. (Also available at http://pubs.usgs.gov/ of/2004/1034/.)

Neal, C.A., McGimsey, R.G., Dixon, J.P., Manevich, Alexander, and Rybin, Alexander, 2008b, 2006 Volcanic activity in Alaska, Kamchatka, and the Kurile Islands-Summary of events and response of the Alaska Volcano Observatory: U.S. Geological Survey Scientific Investigations Report 2008-5214, 102 p. (Also available at http://pubs.usgs.gov/sir/2008/5214/.)

Neal, C.A., McGimsey, R.G., and Doukas, M.P., 1996, 1993 Volcanic activity in Alaska-Summary of events and response of the Alaska Volcano Observatory: U.S. Geological Survey Open-File Report 96-24, 21 p. (Also available at http://geopubs.wr.usgs.gov/open-file/of96-24/.)

Neal, C.A., McGimsey, R.G., and Girina, O.A., 2005, 2002 Volcanic activity in Alaska and Kamchatka-Summary of events and response of the Alaska Volcano Observatory: U.S. Geological Survey Open-File Report 2004-1058, 51 p. (Also available at http://pubs.usgs.gov/of/2004/1058/.) 
Neal, Christina, Rybin, Alexander, Chibisova, Marina, and Miller, Edward, 2008a, Active volcanoes of the Kurile Islands-A reference guide for aviation users: U.S. Geological Survey Open File Report 2008-1162, 10 p.

Ponomoreva, V.V., Kyle, P., Pevzner, M., Sulerzhitsky, L., and Hartman, M., 2008, Holocene eruptive history of Shiveluch Volcano, Kamchatka Peninsula, Russia in Eichelberger, J., Gordeev, E., Kasahara, M., Izbekov, P., and Lees, J., eds., Volcanism and Subduction-The Kamchatka Region: AGU Geophysical Monograph Series, v. 172, p. 263-282.

Ponomareva, V.V., Pevzner, M.M., and Melekestsev, I.V., 1998, Large debris avalanches and associated eruptions in the Holocene eruptive history of Shiveluch Volcano, Kamchatka, Russia: Bulletin of Volcanology, v. 59, no. 7, p. 490-505.

Richter, D.H., Rosenkrans, D.S., and Steigerwald, M.J., 1995, Guide to the volcanoes of the western Wrangell Mountains, Alaska-Wrangell-St. Elias National Park and Preserve: U.S. Geological Survey Bulletin 2072, 31 p.

Richter, D.H., Waythomas, C.F., McGimsey, R.G., and Stelling, P.L., 1998, Geologic map of Akutan Island, Alaska: U.S. Geological Survey Open-File Report 98-135, 22 p. + plate.

Riehle, J.R., Fleming, M.D., Molnia, B.F., Dover, J.H., Kelley, J.S., Miller, M.L., Plafker, George, and Till, A.B., 1997, Shaded relief image of Alaska: U.S. Geological Survey Miscellaneous Investigations Series MI-2585.

Roach, A.L., Benoit, J.P., Kean, K.G., and McNutt, S.R., 2001, The combined use of satellite and seismic monitoring during the 1996 eruption of Pavlof Volcano, Alaska: Bulletin of Volcanology, v. 62, p. 385-399.

Rybin, A.V., Karagusov, Y.V., Izbekov, Pavel, Terentyev, N.S., Guryanov, V.B., Neal, C.A., and Dean, K., 2004, Status of monitoring active volcanoes of the Kurile Islands-Present and future, in Proceedings of the Second International Conference on Volcanic Ash and Aviation Safety. Published by the Office of the Federal Coordinator for Meteorological Services and Supporting Research, p. 61-66.

Schaefer, J.R., Cameron, C.E., and Nye, C.J., 2009, Historically active volcanoes of Alaska: Alaska Division of Geological and Geophysical Surveys Miscellaneous Publication 133, 1 sheet, scale 1:3,000,000. (Also available at http://www.dggs.dnr.state.ak.us/pubs/pubs?reqtype=citati on\&ID=20181).
Siebert, L., and Simkin, T., 2002-, Volcanoes of the World: An Illustrated Catalog of Holocene Volcanoes and their Eruptions: Smithsonian Institution, Global Volcanism Program Digital Information Series, GVP-3, accessed July 6, 2010, at http://www.volcano.si.edu/world/.

Simkin, Tom, and Siebert, Lee, 1994, Volcanoes of the World [2nd ed.]: Tucson, Arizona, Geoscience Press, Inc., 349 p.

Smith, W.H.F., and Sandwell, D.T., 1977, Global seafloor topography from satellite altimetry and ship depth soundings: Science, v. 277, p. 1957-1962.

Till, A.B., Yount, M.E., and Riehle, J.R., 1993, Redoubt Volcano, southern Alaska: A hazard assessment based on eruptive activity through 1968: U.S. Geological Survey Bulletin 1996, 19 p.

Waitt, R.B., and Begét, J.E., 2009, Volcanic processes and geology of Augustine Volcano, Alaska: U.S. Geological Survey Professional Paper 1762, 78 p., 2 plates, scale 1:25,000. (Also available at http://pubs.usgs.gov/pp/1762/.)

Waythomas, C.F., Prejean, S.G., and McNutt, S.R., 2008, Alaska's Pavlof Volcano ends 11-year repose: Eos (American Geophysical Union Transactions), v. 89, n. 23, p. 209-211.

Waythomas, C.F., Miller, T.P., and Mangan, M.T., 2006, Preliminary volcano hazard assessment for the Emmons Lake Volcanic Center, Alaska: U.S. Geological Survey Scientific Investigations Report 2006-5248, 32 p.

Waythomas, C.F., Power, J.A., Richter, D.H., and McGimsey, R.G., 1998, Preliminary volcano-hazard assessment for Akutan Volcano east-central Aleutian Islands, Alaska: U.S. Geological Survey Open-File Report OF 98-0360, 36 p., 1 plate.

Zharinov, N.A., Bogoyavlenskaya, G.E., Khubunaya, S.A., and Demyanchuk Yu.V., 1995, A new eruption cycle of Shiveluch Volcano, 1980-1993: Volcanology and Seismology, v. 17, p. 21-30 (in Russian). 


\section{Glossary of Selected Terms and Acronyms}

\author{
AAWU: “Alaska Aviation Weather Unit” of \\ the National Weather Service. \\ `à: Hawaiian term for lava flows \\ characterized by a rough, jagged, blocky \\ surface.
}

AEIC: Alaska Earthquake Information Center.

AFTN: Aeronautical Fixed Telecommunications Network.

AKDGGS: Alaska Division of Geological and Geophysical Surveys.

AKDT: “Alaska Daylight Time”; UTC -8 hours AKDT.

AKST: “Alaska Standard Time”; UTC -9 hours AKST.

andesite: volcanic rock composed of about 53-63 percent silica $\left(\mathrm{SiO}_{2}\right.$; ; an essential constituent of most minerals found in rocks).

ash: fine fragments (less than $2 \mathrm{~mm}$ across) of lava or rock formed in an explosive volcanic eruption.

ASL: above sea level.

ASTER: Advanced Spaceborne Thermal Emission and Reflection Radiometer.

Aura: a multi-national NASA scientific research satellite in orbit around the Earth, studying the Earth's ozone layer, air quality and climate.

AVHRR: “Advanced Very High Resolution Radiometer;” AVHRR provides one form of satellite imagery.

AV0: Alaska Volcano Observatory.

basalt: general term for dark-colored igneous rock, usually extrusive, containing about 45-52 weight percent silica $\left(\mathrm{SiO}_{2}\right.$, an essential constituent of most minerals found in rocks).

bomb: boulder-size chunk of partly solidified lava explosively ejected from a volcano.

caldera: a large, roughly circular depression usually caused by volcanic collapse or explosion.
CAVW: Smithsonian Institute's “Catalog of Active Volcanoes of the World" (Simkin and Siebert, 1994).

cinder cone: small, steep-sided conical hill built mainly of cinder, spatter, and volcanic bombs.

COSPEC: “Correlation Spectrometer,” a device for measuring sulfur-dioxide emissions.

CWSU: “Center Weather Service Unit” of the National Oceanic and Atmospheric Administration, stationed at the Air Route Traffic Control Center.

CVO: Cascade Volcano Observatory.

ERSDAC: Earth Remote Sensing Data Analysis Center.

FAA: Federal Aviation Administration.

fallout: a general term for debris that falls to the Earth from an eruption cloud.

fault: A fracture along which the blocks of the Earth's crust on either side have moved relative to one another parallel to the fracture.

FIR: Flight Information Region.

fissure: a roughly linear or sinuous crack or opening on a volcano; a type of vent which commonly produces lava fountains and flows.

FLIR: “Forward Looking Infrared Radiometer," used to delineate objects of different temperature.

fumarole: a small opening or vent from which hot gases are emitted.

GSFC: Goddard Space Flight Center.

glaciolacustrine: pertaining to sediments deposited in glacial lakes, and resulting landforms.

GMS: Geostationary Meteorological Satellite.

GOES: Geostationary Operational

Environmental Satellite.

GPS: Global Positioning System.

GVN: "Global Volcanism Network" of the Smithsonian Institution. 
Holocene: geologic epoch extending from the present to 10,000 years ago.

IMGG: Russian "Institute of Marine Geology and Geophysics."

incandescent: glowing red or orange due to high temperature.

InSAR: Interferometric Synthetic Aperture Radar.

interferogram: a pattern formed by wave interference, especially one represented in a photograph or diagram

intracaldera: refers to something within the caldera.

ISS: International Space Station.

IVS: Russian "Institute of Volcanology and Seismology."

JAROS: Japan ASTER Science Team.

JMA: Japanese Meteorological Agency.

JPEG: “Joint Photographic Experts Group," type of digital photographic file.

Ka: thousands of years before the present.

KDT: "Kamchatkan Daylight Time” equals AKDT + 21 hrs.

KBGS: Kamchatka Branch of Geophysical Surveys.

KEMSD: Russian "Kamchatka Experimental and Methodical Seismological Department."

KST: "Kamchatka Standard Time” equals AKST + 21 hours.

KVERT: Kamchatkan Volcanic Eruption Response Team.

lapilli: pyroclasts or volcanic fragments that are between 2 and $64 \mathrm{~mm}$ in diameter.

lava: molten material at the Earth's surface.

magma: molten material below the surface of the Earth.

METI: Ministry of Economy, Trade, and Industry.

MODIS: Satellite-based "Moderate-resolution Imaging Spectroradiometer.”

MW0: Meteorological Watch Office.

NASA: National Aeronautics and Space Administration.

NOAA: National Oceanic and Atmospheric Administration.

NOGAPS: Navy Operational Global Atmospheric Prediction System.
NOPAC: North Pacific air route corridors.

NOTAM: “Notice to Airmen," a notice containing information [not known sufficiently in advance to publicize by other means] concerning the establishment, condition, or change in any component [facility, service, or procedure of, or hazard in the National Airspace System] the timely knowledge of which is essential to personnel concerned with flight operations.

NPS: National Park Service.

NWS: National Weather Service.

OMI: Ozone Mapping Instrument.

phreatic activity: an explosive eruption caused by the sudden heating of groundwater as it comes in contact with hot volcanic rock or magma.

phreatic ash: fine fragments of volcanic rock expelled during phreatic activity; this ash usually is derived from existing rock and not from new magma.

PIREP: "Pilot Weather Report;" a report of meteorological phenomena encountered by aircraft in flight.

pixel: contraction of "picture element." A pixel is one of the many discrete rectangular elements that form a digital image or picture on a computer monitor or stored in memory. In a satellite image, resolution describes the size of a pixel in relation to area covered on the ground. More pixels per unit area on the ground means a higher resolution.

PK: "Petropavlovsk"; capital city of Kamchatka, Russia.

Pleistocene: geologic epoch extending from 2-3 million years ago to approximately 10,000 years before present.

PUFF: a volcanic ash tracking model (see at URL: http://puff.images.alaska.edu/ monitoring.shtml).

pyroclast: an individual particle ejected during a volcanic eruption; usually classified by size, for example, ash, lapilli.

RSAM: Real-time Seismic-Amplitude Measurement.

regional earthquake: earthquake generated by fracture or slippage along a fault; not caused by volcanic activity.

RFE: Russian Far East.

SAB: "Synoptic Analysis Branch" of NOAA. 
SAR: Synthetic Aperture Radar.

satellite cone: a subsidiary volcanic vent located on the flank of a larger volcano.

seismic swarm: a flurry of closely spaced earthquakes or other ground shaking activity; often precedes an eruption.

shield volcano: a broad, gently sloping volcano usually composed of fluid lava flows of basalt composition (for example, Mauna Loa, Hawaii).

SI: Internation System of Units.

SIGMET: SIGnificant METeorological information statement, issued by NWS.

SRTM: Shuttle Radar Topography Mission.

Stratovolcano: Also called a stratocone or composite cone, a steep-sided volcano, usually conical in shape, built of interbedded lava flows and fragmental deposits from explosive eruptions.

Strombolian: type of volcanic eruption characterized by intermittent bursts of fluid lava, usually basalt, from a vent or crater as gas bubbles rise through a conduit and burst at the surface.

sub-plinian: style of explosive eruptions characterized by vertical eruption columns and widespread dispersal of tephra.

SVA: Suspect Volcanic Activity.

SVERT: "Sakhalin Volcanic Eruption Response Team" monitors and reports on Kurile Island volcanoes.

SWIR: Short Wave Infrared. tephra: a general term covering all fragmental material expelled from a volcano (ash, bombs, cinders, etc.).

TA: thermal anomaly.

TFR: “Temporary Flight Restriction,” issued by FAA.

TIR: Thermal Infrared.

UAFGI: University of Alaska Fairbanks Geophysical Institute.

USCG: United States Coast Guard.

USFWS: United States Fish and Wildlife Service.

USGS: United States Geological Survey.

UTC: "Coordinated Universal Time”; same as Greenwich Mean Time (GMT).

UUA: Urgent pilot report.

VAAC: Volcanic Ash Advisory Center.

VAA: Volcanic Ash Advisory.

vent: an opening in the earth's surface through which magma erupts or volcanic gasses are emitted.

VNIR: Very Near Infrared.

volcano-tectonic earthquakes: earthquakes generated within or near a volcano from brittle rock failure resulting from strain induced by volcanic processes.

Vulcanian: style of explosive eruption consisting of repeated, violent ejection of incandescent fragments of viscous lava, usually in the form of blocks, along with volcanic ash. Sometimes, Vulcanian eruptions involve water mixing with erupting magma. 
This page intentionally left blank. 


\section{Appendix 1. Volcano Alert Levels and Revised Aviation Color Codes Used by United States Observatories.}

Alert levels address the overall activity at the volcano, not just the hazard to aviation. There may be situations where a volcano is producing lava flows that are dangerous on the ground and merit a WATCH or WARNING, however, the hazard to aviation is minimal. Alert levels announcements contain additional explanation of volcanic activity and expected hazards where possible (Gardner and Guffanti, 2006).

\begin{tabular}{|c|l|}
\hline \multicolumn{2}{|c|}{ Alert Levels } \\
\hline NORMAL & $\begin{array}{l}\text { Typical background activity of a volcano in a non-eruptive state. } \\
\text { Or, after a change from a higher level: } \\
\text { Volcanic activity considered to have ceased and volcano reverted to its normal, non-eruptive state }\end{array}$ \\
\hline ADVISORY & $\begin{array}{l}\text { Elevated unrest above known background activity. } \\
\text { Or, after a change from a higher level: } \\
\text { Volcanic activity has decreased significantly but continues to be closely monitored for possible renewed increase. }\end{array}$ \\
\hline WATCH & $\begin{array}{l}\text { Volcano is exhibiting heightened or escalating unrest with increased potential for eruptive activity. } \\
\text { Or: } \\
\text { A minor eruption is underway that poses limited hazards. }\end{array}$ \\
\hline WARNING & Highly hazardous eruption underway or imminent. \\
\hline
\end{tabular}

\section{Level of Concern Codes for Aviation}

AVO will continue to use the color-coded level of concern designation that has been in place since 1990. Colors will now reflect only the hazards posed to the aviation community. Definitions of each color have changed slightly. Typically, this means that color codes indicate the likelihood or presence of airborne ash and ash clouds that threaten aircraft.

\begin{tabular}{|c|l|}
\hline \multirow{2}{*}{ GREEN } & $\begin{array}{l}\text { Volcano is in a normal, non-eruptive state. } \\
\text { Or, after a change from a higher level: } \\
\text { Volcanic activity considered to have ceased and volcano reverted to its normal, non-eruptive state }\end{array}$ \\
\hline \multirow{2}{*}{ YELLOW } & $\begin{array}{l}\text { Volcano is exhibiting signs of elevated unrest above known background levels. } \\
\text { Or, after a change from a higher level: } \\
\text { Volcanic activity has decreased significantly but continues to be closely monitored for possible renewed increase. }\end{array}$ \\
\hline \multirow{2}{*}{ ORANGE } & $\begin{array}{l}\text { Volcano is exhibiting heightened unrest with increased likelihood of eruption. } \\
\text { Oolcanic eruption underway with no or minor ash emission. }\end{array}$ \\
\hline RED & $\begin{array}{l}\text { Eruption is forecast to be imminent with significant emission of ash into the atmosphere likely. } \\
\text { Oruption is underway with significant emission of ash into the atmosphere. }\end{array}$ \\
\hline
\end{tabular}




\section{Appendix 2. Level of Concern Color Code for Volcanic Activity Used in Kamchatka and the Kurile Islands in 2007.}

\begin{tabular}{|c|c|}
\hline & Level of Concern Color Code: Generic \\
\hline \multirow{2}{*}{ GREEN } & No eruption anticipated. \\
\hline & Volcano is in quiet “dormant” state. \\
\hline \multirow{2}{*}{ YELLOW } & An eruption is possible in the next few weeks and may occur with little or no additional warning. \\
\hline & Small earthquakes detected locally and (or) increased levels of volcanic gas emissions. \\
\hline \multirow{2}{*}{ ORANGE } & $\begin{array}{l}\text { Explosive eruption is possible within a few days and may occur with little or no warning. Ash plume(s) not } \\
\text { expected to reach } 25,000 \text { feet above sea level. }\end{array}$ \\
\hline & $\begin{array}{l}\text { Increase numbers of local earthquakes. Extrusion of a lava dome or lava flows (non-explosive eruption) may be } \\
\text { occurring. }\end{array}$ \\
\hline \multirow{2}{*}{ RED } & $\begin{array}{l}\text { Major explosive eruption expected within } 24 \text { hours. Large ash plume(s) expected to reach at least } \\
25,000 \text { feet above sea level. }\end{array}$ \\
\hline & Strong earthquake activity detected even at distant monitoring stations. Explosive eruption may be in progress. \\
\hline
\end{tabular}


Publishing support provided by the U.S. Geological Survey Publishing Network, Tacoma Publishing Service Center

For more information concerning the research in this report, contact the Director, Volcano Science Center

U.S. Geological Survey

4200 University Drive

Anchorage, Alaska 99508

http://volcanoes.usgs.gov/ 
